\title{
Buku Ajar Mata Kuliah \\ Relasi Antara Aqidah dan Akhlaq
}

\author{
Oleh \\ Dzulfikar Akbar Romadlon, M.Ud. \& Dr. Istikomah, \\ M.Ag
}

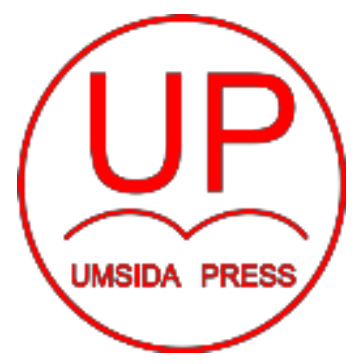

Diterbitkan oleh

UMSIDA PRESS

Tahun 2019 


\section{Buku Ajar}

Relasi Antara Aqidah dan Akhlaq

\section{Penulis :}

Dzulfikar Akbar Romadlon, M.Ud. \& Dr. Istikomah, M.Ag.

ISBN : 978-623-7578-14-7

\section{Editor :}

Septi Budi Sartika, M.Pd

M. Tanzil Multazam, S.H., M.Kn.

Copy Editor :

Fika Megawati, S.Pd., M.Pd.

Design Sampul dan Tata Letak :

Mochamad Nashrullah, S.Pd

Penerbit :

UMSIDA Press

\section{Redaksi :}

Universitas Muhammadiyah Sidoarjo

J1. Mojopahit No 666B

Sidoarjo, Jawa Timur

Cetakan pertama, Agustus 2019

C) Hak cipta dilindungi undang-undang Dilarang memperbanyak karya tulis ini dengan suatu apapun tanpa ijin tertulis dari penerbit. 


\section{PROLOG}

\section{AKHLAQ BERBASIS WORLDVIEW ISLAM}

\section{PROBLEM KEYAKINAN DAN MORALITAS}

Diskusi ini akan dimulai dari pertanyaan mendasar mengenai absolutisme moral. Pertanyaan paling mendasar dalam wacana ini adalah, apakah keyakinan mempengaruhi pandangan seseorang tentang moralitas? Apa yang dimaksud dengan perbuatan yang baik dan yang buruk? Apakah baik/buruk menurut sebagian orang sama dengan menurut yang lainnya?

Pertama akan dipaparkan fakta yang berbeda tentang nilai etis di dunia Islam dan di dunia Barat ${ }^{1}$ dalam hal etika berpakaian. Dalam Islam wanita wajib mengenakan hijab, berdasarkan kewajiban ini akan banyak ditemui wanita muslimah di dunia Islam yang menggunakan hijab, walaupun ada yang tidak menggunakannya, namun mereka meyakini bahwa menggunakan hijab adalah sesuatu yang baik. Namun, bagi sebagian masyarakat Barat, penggunaan hijab apalagi cadar adalah sesuatu yang buruk, bahkan para feminis mengatakan bahwa hijab adalah pengekangan bagi kebebasan wanita. $^{2}$ Sedangkan di Barat adalah hal yang biasa jika wanita

1 Yang dimaksud dengan dunia Islam adalah wilayah yang memiliki kultur-budaya masyarakat yang berkaitan erat dengan Islam. Sedangkan dunia Barat adalah wilayah yang berkultur-sosial-budaya Eropa; namun bukan berarti ia hanya terletak di benua Eropa saja, namun semua wilayah ataupun negara yang mengadopsi kultur, filsafat pemikiran Eropa, seperti Amerika dan Australia. Lihat di Jackson J. Spielvogel, Western Civilization, 7th edn (Canada: Thomson Wadsworth).

${ }^{2}$ Lihat di beberapa tulisan yang menolak Hijab di Barat Daphne Grace, The Woman in the Muslim Mask, 1st edn (London: Pluto Press, 2004), juga di 
mengenakan rok diatas lutut atau baju yang tidak menutupi lengan, bahkan jika di pantai, cukup bagi wanita untuk mengenakan bikini saja. Tentunya pakaian semacam ini diharamkan dalam ajaran Islam dan dianggap tidak etis bagi masyarakat Islam.

Lalu apakah yang membedakan kedua pandangan ini? Seorang muslimah akan menggunakan hijab bukan karena suka atau tidak suka, manusiawi atau tidak manusiawi, namun hijab adalah perintah agama yang harus dijalani, sebagai bentuk ketundukan terhadap Allah Swt. Disini dapat dilihat bahwa pada dasarnya nilai etika dalam Islam berdasarkan pada nilai ketuhanan. ${ }^{3}$ Berbeda dengan manusia di Barat yang tidak beriman kepada Allah sehingga mereka tidak mendasarkan nilai moralnya kepada Allah. Sehingga dasar dari nilai etikanya menjadi apa yang disukai oleh masing-masing individu, selama tidak mengganggu kebebasan orang lain.

Etika dan moral di Barat kini telah bergeser dari moral kristiani menuju moral liberal-atheis yang antrophosentris (berpusat pada manusia). Pergeseran itu dapat dilihat dari adagium Nietzsche yang terkenal "God is death", kematian tuhan ditandai dengan berpisahnya masyarakat Eropa dari kristianitas menuju pada liberasi pemikiran. ${ }^{4}$ Sehingga moralitas tidak lagi theosentris (berpusat pada Tuhan), namun manusia mengambil alih otoritas dalam menentukan nilai moral sehingga ia adalah ukuran bagi kebenaran itu. Walhasil,

Marnia Lazerg, Questioning the Veil: Open Letters to Muslim Women (Princenton: Princenton University Press, 2019)

${ }^{3}$ Lihat di Abdu I-Aziz Marzuq Al-Tarifi, Al-Hijab Fi I-Shar' Wa l-Fitrah, 1st edn (Riyad: Maktabah Darul Manhaj); Abu I-A'laa Al-Maududi, Al-Hijab, 2nd edn (Damaskus: Daaru l-Fikri, 1964).

${ }^{4}$ Lihat tulisan Friedrich W. Nietzsche, Thus Spake Zarathustra, ed. by Thomas Common (USA: The Modern Libarary); banyak berbicara tentang kematian Tuhan, dan lihat tentang penafsiran kematian Tuhan di Eric Steinhart, On Nietzsche (USA: Wadsworth, 2000). p. 18-19 
kebenaran moral menjadi relatif, sehingga manusia dapat dengan bebas melegalkan secara etis maupun hukum berbagai perilaku yang dulunya adalah buruk. Usaha untuk melegalkan perilaku-perilaku seperti: free-sex, gay, lesbian, pornografi dapat ditemukan dalam tulisan-tulisan pemikir, sarjana, dan penulis di Barat yang inti semuanya adalah menekankan pada kebebasan personal yang tidak mengganggu kebebasan orang lain, manusia bebas memilih walaupun pilihan itu buruk, sehingga perbuatan yang amoral, selama itu tidak mengganggu kebebasan orang lain, maka ia menjadi bermoral. $^{5}$

Sumber perbedaan dua cara pandang ini antara Islam dan Barat dapat diruntut asalnya bermuara dari keyakinan mereka terhadap Tuhan. Keyakinan seorang muslim kepada Tuhannya mengharuskannya untuk mengaitkan semua perbuatannya dan pandangan moralnya kepada Tuhannya. Sedangkan keyakinan Barat yang atheis (tidak percaya Tuhan)ataupun agnostik (tidak ingin tahu tentang Tuhannya) membebaskan perbuatannya dan pandangan moralnya dari Tuhannya. pandangan manusia tentang Tuhan, baik meyakini ataupun mengingkari, akan membentuk sistem keyakinan yang disebut dengan worldview atau pandangan manusia terhadap dunia.

\section{WORLDVIEW}

${ }^{5}$ Lihat tulisan-tulisan yang mencoba melakukan legalisasi homosexsual, pornography di Lori Gruen and George E. Panichas, Sex, Morality and The Law (New York: Routledge, 1997). Gilbert Herdt, Moral Panics, Sex Panics: Fear and Fight over Sexual Rights, ed. by Gilbert Herdt (New York: New York University Press, 2009). 
Sebelum menganalisa apa itu worldview Islam, pertama kita perlu mendefinisikan terlebih dahulu apa itu worldview/pandangan tentang dunia?. James W. Sire mendefinisikan worldview sebagai:

"A worldview is a set of presuppositions (assumptions which may be true, partially true or entirely false) which we hold (consciously or subconsciously, consistently or inconsistently) about the basic makeup of our world."

Terjemahan bebasnya: worldview adalah sekumpulan dari presuposisi (asumsi yang bisa jadi benar, atau sebagaian benar, atau semuanya salah) yang kita yakini (secara sadar atau setengah sadar, secara konsisten atau tidak konsisten) tentang bentuk dunia yang paling dasar. Atau dapat disimpulkan bahwa worldview berisi tentang asumsi tentang bentuk dasar dunia ini atau pandangan ontologis yang paling dasar tentang dunia, atau tentang apa, bagaimana, darimana bentuk dunia ini? Jawaban tiap worldview akan berbeda satu dengan yang lainnya. Worldview disebut asumsi karena kebenarannya belum dibuktikan secara saintifik, namun tetap diyakini oleh orang yang meyakininya. Maka worldview atau weltanschauung (bahasa Jerman), menurut Ninian Smart, dibangun di atas system kepercayaan atau worldview itu adalah keyakinan itu sendiri. ${ }^{7}$ Smart menjelaskan lebih jauh bahwa pandangan masyarakat ataupun kelompok dipengaruhi didalamnya doktrin, kisah-kisah mistis, hukum ethis, ritual, pengalaman keberagamaan, dan dimensi social, sehingga struktur pandang suatu masyarakat atau kelompok bisa dibedakan dengan yang lainnya. ${ }^{8}$

\footnotetext{
${ }^{6}$ James W. Sire, Naming the Elephant: Worldview as a Concept (Illionis: Intervarsity Press, <https://doi.org/10.1163/157338308X365567>.p.19 2010)

${ }^{7}$ Ninian Smart, Worldviews Cultural Exploraties of Human Biliefs, 2nd edn (New York: Charles Scribner's Sons). p. 1

${ }^{8}$ Smart. p. 7-8
} 
Sistem keyakinan dalam worldview berkaitan erat dengan konsep Tuhan yang diyakini sebagaimana yang disebutkan oleh David Keith Naugle dan James W. Sire. ${ }^{9}$ Lebih lanjut Konsep tentang Tuhan ini menurut Sire merupakan konsep yang secara sadar ataupun tidak sadar, dan secara konsisten menciptakan bangunan worldviewnya. Untuk mempertegas hal ini, Naugle dan Sire mengemukakan beberapa pertanyaan filosofis yang menjadi landasan worldview dan semuanya berkaitan dengan konsep Tuhan: ${ }^{10}$

1. Apa itu realitas tertinggi atau apa itu yang benar-benar nyata?

Bisa jadi seseorang mengatakan bahwa realitas tertinggi adalah Tuhan, atau jiwa, atau ide, atau materi jawaban itu akan mengikuti pertanyaan berikutnya.

2. Apa sifat alamiah dari dunia sekitar kita?

Jika ia ber-Tuhan mungkin akan berkata bahwa alam diciptakan, atau mungkin akan mengatakan bahwa Tuhan hanya menciptakan alam di awal saja kemudian alam berjalan dengan sendirinya. Jika ia tidak percaya Tuhan tentu ia akan berkata bahwa alam ada dengan sendirinya. Kemudian dia mungkin akan mengatakan bahwa alam ini kacau atau teratur, bersifat materi ataukah ruhani, hanya ada satu alam ataukah banyak alam, semuanya akan mempengaruhi di pertanyaan berikutnya.

3. Apa itu manusia?

Mungkin seorang yang ber-Tuhan akan mengatakan bahwa manusia adalah wajah dari Tuhan, pengganti Tuhan, makhluk Tuhan

9 David Keith Naugle, 'The History and Theory of the Concept Weltanschauung' (The University of Texas, 1998).p. 569.

${ }^{10}$ James W. Sire, The Universe Next Door: A Basic Worldview Catalog, 5th edn (Illionis: InterVarsity Press, 2009). p. 22-23 
tertinggi, namun jika seseorang tidak percaya Tuhan mungkin ia akan mengatakan, bahwa manusia adalah evolusi tertinggi dari kera, atau ia adalah bentuk mesin tertinggi yang diciptakan alam, atau bahkan ia adalah keturunan dari entitas yang ada di luar angkasa.

4. Apa yang terjadi setelah manusia mati?

Mungkin seorang yang ber-Tuhan akan berkata, bahwa manusia akan pergi ke-alam lain, manusia akan berrenkarnasi. Namun jika ia tidak bertuhan pasti akan mengatakan bahwa kematian adalah kesirnaan personal.

5. Mengapa manusia dapat mengetahui segala hal? (pertanyaan epistemologis)

Mungkin seorang yang ber-Tuhan akan berkata bahwa manusia dapat mengetahui karena Tuhan telah menciptakan intelegensia dalam diri manusia, namun orang yang tidak bertuhan akan mengatakan bahwa intelegensi manusia terbentuk setelah proses evolusi yang lama.

6. Bagaimana cara kita mengetahui yang baik dan yang buruk? (pertanyaan moral)

Mungkin seorang yang ber-Tuhan akan mengatakan bahwa benar dan salah berasal dari Tuhan, sedangkan orang yang tidak bertuhan akan mengatakan bahwa benar dan salah adalah pilihan manusia, apa yang ia sukai maka itu baik dan apa yang dibenci maka itu buruk.

7. Apa tujuan dari manusia?

Seorang yang ber-Tuhan mungkin akan mengatakan bahwa tujuan dari manusia adalah untuk menjadi wakil Tuhan, atau manusia harus menciptakan masyarakat yang mencintai Tuhan dsbg. Namun orang yang tidak bertuhan mungkin akan mengatakan bahwa tujuan 
dari manusia adalah untuk kebebasan, untuk bersenang-senang, untuk bahagia, atau yang lainnya.

Berdasarkan pernyataan-pernyataan ini setiap orang pasti akan memilih salah satu pilihan dalam hidupnya, apakah ia akan meyakini Tuhan ataukah tidak?, agama apa yang dipilihnya?, jawaban dari pernyataan ini ketika dipilih oleh seseorang akan menciptakan komitmen dalam dirinya, worldview atheis berbeda dengan worldview orang yang beragama, worldview seorang muslim berbeda dengan seorang kristiani. Begitu pula worldview antar agama, keyakinan, dan ideologi semuanya memiliki karakteristiknya masing-masing, ketika menjadi pilihan seseorang maka secara konsistent akan membentuk keseluruhan pandangannya terhadap dunia disekitarnya.

\section{WORLDVIEW ISLAM}

Ketika dikatakan "Worldview Islam" sekilas akan dipahami sebagai cara pandang seorang muslim dalam melihat dunia, atau berdasarkan definisi oleh James W. Sire diatas; Worldview Islam adalah sekumpulan presuposisi atau asumsi yang diyakini oleh seorang muslim tentang bentuk dunia yang paling dasar. Namun definisi worldview semacam ini menjadi bermasalah, karena dua sebab:

Pertama adalah kalimat "asumsi" berarti dugaan atau sesuatu yang diyakini benar, namun belum tentu benar, berarti tidak ada kepastian atas kebenarannya. Sedangkan Al-Qur'an melarang seseorang meyakini sesuatu yang salah. Meyakini kebenaran Islam tidak cukup hanya dengan ikut-ikutan namun diperlukan penalaran logis (QS 2:170). Islam memandang bahwa mengetahui suatu kebenaran adalah mungkin. Setelah manusia mengoptimalkan 
penggunaan indera, akal, dan intuisi, maka mungkin bagi seseorang untuk mencapai kebenaran (QS 22:46, 7:179\&195).

Para ulama' muslim telah melakukan pembuktian dan penyelidikan baik secara logis dan empiris terhadap kebenaran Islam. Diantara para ulama ada yang membuktikan kebenaran Islam dengan bukti-bukti logis berdasarkan ayat-ayat Al-Qur'an, mereka adalah para ulama' kalam yang mampu menunjukkan bahwa Islam yang bersumber dari Al-Qur'an dan Al-Hadith, tidak akan pernah bertolak belakang dengan hukum akal manusia. Diantara mereka ada yang melakukan pembuktian melalui hukum logika yang telah dikembangkan oleh filosof muslim peripatetik, yakni filosof muslim yang mengembangkan metodologi berfikir filosofis ala Yunani. Terakhir, ada diantara mereka yang membuktikan kebenaran Islam melalui penalaran intuituif, mereka adalah ulama' sufi yang mencoba melakukan penalaran intuitif terhadap ajaran Islam, walaupun banyak dari mereka yang mencampurkan pembuktian intuitif-logis terhadap ajaran Islam.

Kebenaran dalam Islam itu satu, tidak ada dua kebenaran dalam satu hal, atau tidak mungkin suatu perbuatan disebut baik dan buruk sekaligus, sehingga Islam menolak berbagai bentuk relativisme yang menjadikan tidak ada kebenaran yang pasti. Maka meletakkan Worldview Islam sebagai "asumsi yang diyakini", sama dengan mengatakan "ajaran Islam itu hanyalah praduga semata." Sebuah keyakinan disebut benar ketika apa yang diyakini dalam fikiran sesuai dengan apa yang ada di luar, berarti keyakinan sama dengan pengetahuan dan kebenaran. Adalah keyakinan yang salah jika meyakini sesuatu yang berbeda dengan yang terjadi di luar. Dengan demikian, dalam Islam seorang manusia hanya boleh meyakini yang benar saja, وما بعد الحقّ إلاّ الضلال atau tidak ada sesuatu di luar kebenaran kecuali kesalahan (QS 10:32). 
Kedua, istilah worldview sendiri, jika diterjemahkan: pandangan manusia terhadap dunia atau dalam bahasa Arab ru'yatu I-Islam li l-kawn (رؤية الإسـام للكون), namun hal ini jika ditinjau dari sudut pandang Islam kurang tepat. Karena realitas yang diafirmasi dalam Islam bukan hanya mencakup dunia ini saja, namun cangkupannya dunia dan juga akhirat, realitas yang nampak dan tidak nampak. Maka Syed Naquib Al-Attas lebih suka menerjemahkan istilah Worldview Islam dengan ru'yatu I-Islam li I-wujud (رؤية الإسلام للوجود) diterjemahkan: pandangan Islam terhadap semua yang wujud; ${ }^{11}$ atau dalam bahasa Sayyid Qutb yang serupa tafsir syamil li l-wujud (تفسير شامل للوجود) diterjemahkan: penafsiran yang utuh (bagi muslim) tentang wujud;; ${ }^{12}$ atau dengan bahasa filosofisnya adalah pandangan ontologi Islam.

Pandangan Islam tentang wujud berbasis Tauhid, yakni: mengesakan Allah, atau terangkum dalam kalimat, "tiada tuhan selain Allah", ${ }^{13}$ hanya ada satu Tuhan yang berkuasa dan mencipta. Dalam Aqidah Islam itu sangat sederhana, tidak ada doktrin Trinitas ataupun Kaballah yang rumit. Walaupun sangat sederhana, bukan berarti konsep Tauhid itu salah. Hal ini dapat dilihat dari pembuktian-pembuktian para mutakallim, filosof peripatetik, dan kaum sufi; bahwa wujud dan keesaan Allah adalah sesuatu keniscayaan.

${ }^{11}$ Syed Muhammad Naquib Al-Attas, Prolegomena to The Metaphysic of Islam: An Exposition of The Fundamental Elements of The Worldview of Islam, 1st edn (Kuala Lumpur: ISTAC, 1995).

${ }^{12}$ Sayyid Qutb, Khasais At-Tasawwur Al-Islami Wa Maqumatuhu, 5th edn (Beirut: Daaru s-Syuruq, 1997).

13 Diskusi meengenai hal ini bisa juga dilihat di Ismail Raji Al-Faruqi, Islamization of Knowledge: General Principles and Work Plan, 3rd edn (Virgiana: IIIT, 1997). 
Dalam Islam, Allah itu memiliki kekuatan, kemampuan, dan kekuasaan yang sempurna, tidak tertandingi, tidak terbayangkan, dan melingkupi semua yang ada. Allah itu satu tidak dua atau lebih, karena jika ada dua Tuhan atau lebih, maka akan ada dua kehendak, salah satu kehendak pasti akan menghancurkan lainnya. Allah itu hidup dan tidak mati, kekal dan abadi, tiada berawal dan tidak berakhir, karena jika la sirna maka tidak pantas disebut Tuhan, karena jika sirna tentu tidak mampu menciptakan makhluqnya. Setiap yang ada adalah ciptaan Allah, Allah menciptakan sesuatu yang belum pernah diciptakan sebelumnya oleh siapapun itu, dan menciptakan dari ketiadaan (creatio ex-nihilio) dan mengatur ciptaannya (QS 10:3/ 10:31/ 13:2), bukan seperti pembuat jam, yang menciptakan jam dari bahan yang sudah ada, lalu jam itu ditinggalkan dan berjalan dengan sendirinya sebagaimana pendapat Aristotle. Allah mengetahui segala sesuatu dari yang terbesar hingga yang terkecil, dari yang umum dan yang khusus. la mengetahui semua yang telah terjadi dan apa yang akan terjadi. Dengan ilmu-Nya, Allah berkehendak apapun yang la inginkan, tidak ada sesuatu yang keluar dari kehendak-Nya dan tidak ada sesuatu yang keluar dari kekuasaan-Nya. Allah menciptakan dan memusnahkan apapun yang la kehendaki (QS 5:17/28:68).

Islam mengajarkan keesaan Allah dan menolak segala bentuk kesyirikan, atau menyembah sesuatu selain Allah, atau meyakini sesuatu selain Allah memiliki kekuatan yang sama seperti Allah. Upaya "islamisasi" terhadap seluruh aspek kehidupan manusia, tidak bisa dilakukan kecuali dengan menghilangkan kesyirikan. Lebih lanjut, menghilangkan kesyirikan menurut Al-Attas adalah upaya "liberasi" atau pembebasan manusia dari animisme dan dinamisme atau pembebasan dari berbagai bentuk penyembahan selain Allah. Kemudian disertai dengan liberasi dari sekularisme yang berusaha memisahkan urusan agama dalam kehidupan manusia, dan liberasi 
dari atheisme yang mencoba menegasikan eksistensi Tuhan dan semua yang ghaib. ${ }^{14}$

Kemudian bagaimanakah manusia dapat mengetahui bahwa Allah itu satu? Para filosof selama berabad-abad telah membicarakan "the ultimate being" atau wujud yang satu dan adikuasa, la menjadi sebab dari seluruh eksistensi yang ada. Aristotle misalkan menyebutnya dengan istilah "the unmove mover" atau yang tidak bergerak namun menggerakkan, ${ }^{15}$ Plotinus menyebutnya dengan "The One" atau yang satu. ${ }^{16}$ Walaupun kemudian Aristotle dan Plotinus masih meyakini adanya dewa-dewa, namun mereka menyadari bahwa pasti ada satu sebab yang menjadi akhir dan awalan dari segala sesuatu. Selain itu juga ada rekaman sejarah Arab Pra-Islam, ${ }^{17}$ sebagaimana yang disebutkan oleh Karen Armstrong, bahwa disitu ada sekelompok orang yang disebut dengan Al-Hanifiyyah atau orang-orang yang memegang erat keyakinan tentang keesaan Allah. Berdasarkan bukti-bukti ini, maka sebenarnya pandangan tentang keesaan Allah adalah sesuatu yang logis dan pasti, serta dapat dibuktikan dengan akal sehat.

Selanjutnya Allah ingin menegaskan eksistensi-Nya kepada umat manusia maka diutuslah nabi-Nya Muhammad Saw dengan diin ul-Islam, dan dengan membawa pedoman berupa kalamullah; Al-Qur'an, dan Al-Hikmah (wisdom) yakni sunnah Nabi atau

\footnotetext{
${ }^{14}$ Syed Muhammad Naquib Al-Attas, Islam and Secularism, 2nd edn (Kuala Lumpur: ISTAC, 1993); Alparslan Acikgenc, Islamic Science: Towards A Definition, 1st edn (Kuala Lumpur: ISTAC, 1996).

${ }^{15}$ Aristotle berkata: "thereis someething which alwas moves the things that are moved, and the first mover must be itself unmoved". Aristotle, Aristotle's Metaphysics, ed. by W. D. Ross (Oxford: Clarendon Press, 1924). P.288 ${ }^{16}$ Plotinus, Enneads, ed. by A.H. Armstrong (London: Harvard University Press, 1988). P. 276

${ }^{17}$ Karen Armstrong, A History of God: The 4,000-Year Quest of Judaism, Christianity and Islam, 1st edn (New York: Ballantine Books, 1994).
} 
perkataan, perbuatan, dan afirmasi (taqrir) Nabi Muhammad terhadap suatu perbuatan ataupun kejadian (QS 2:129). Dengan diutusnya Nabi Muhammad SAW, Allah SWT telah memberikan standart kebaikan dan keburukan, dan memberikan perintah dan larangan, yang berupa Syari'at Islam.

Setelah penjelasan di atas penulis menyimpulkan bahwa worldview Islam berbeda dengan worldview lainnya ia adalah "kebenaran-kebenaran tentang basis dasar seluruh realitas/alam, yang diketahui dengan pasti kemudian diyakini dan diafirmasi kebenarannya oleh Islam atau agama yang diturunkan kepada Nabi Muhammad SAW, kebenaran itu berdasarkan, bersumber, berprinsip, dan pasti tidak bertentangan dengan tauhid." Worldview Islam berdasarkan penjelasan diatas sebenarnya tidak jauh berbeda dengan Aqidah Islam, namun worldview memiliki makna yang lebih filosofis, yakni ketika keyakinan atau aqidah seseorang secara psikologis menciptakan kerangka berfikir (framework) dalam diri seseorang dalam memandang dirinya, alam semesta, Tuhan, moralitas, ilmu dsbg.

Aspek-aspek yang mencakup hal-hal yang berkaitan dengan Worldview Islam, jika ditinjau dari pertanyaan-pertanyaan yang diajukan oleh J. W. Sire dapat dikelompokkan menjadi 7 konsep: 1. Konsep wujud, 2. Konsep alam semesta, 3. Konsep manusia, 4. Konsep eskatologi, 5. Konsep epistemologi dan ilmu, 6. Konsep etika, 7. Konsep teleologi. Dalam pembahasan buku ini akan dijelaskan terkait dengan konsep-konsep diatas walaupun kemudian berada pada sub-sub bahasan di bab-bab tertentu dan tidak dijelaskan secara mendetail.

\section{PENGARUH WORLDVIEW ISLAM TERHADAP AKHLAQ}


Sebuah aqidah ketika diyakini harus mampu menjadi sebuah kerangka berfikir dan mempengaruhi terhadap bagaimana seseorang memandang; bagaimana seseorang bersikap; bagaimana seseorang berbuat. Karena aqidah yang diimani bukan hanya sebagai teori ilmiah saja yang hanya dibaca, diyakini, dibuktikan oleh ilmuwan, tanpa perlu peduli teori itu mempengaruhi framework-nya atau tidak. Namun sebuah aqidah yang diimani memiliki konsekwensi-konsekwensi yang menjadikan keimanan itu benar-benar menjadi worldview manusia. Allah memisalkan aqidah yang telah menjadi worldiew seperti pohon yang tegak lagi bermanfaat:

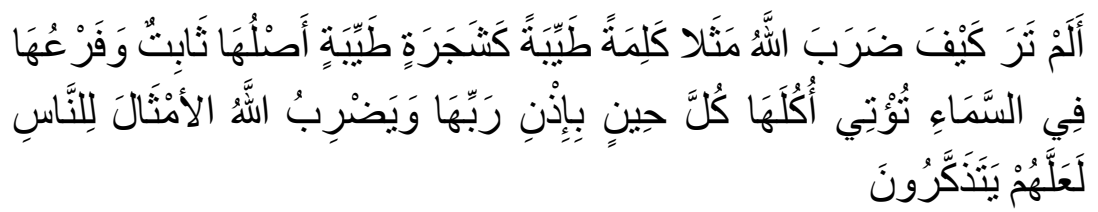

"Tidakkah kamu perhatikan bagaimana Allah telah membuat perumpamaan kalimat yang baik seperti pohon yang baik, akarnya teguh dan cabangnya (menjulang) ke langit, pohon itu memberikan buahnya pada Setiap musim dengan seizin Tuhannya. Allah membuat perumpamaan-perumpamaan itu untuk manusia supaya mereka selalu ingat" (QS 14:24-25).

Kalimat tayyibah atau kalimat yang baik, sebagaimana yang disarikan dari berbagai riwayat dalam Tafsir At-Thabari, maksudnya adalah keimanan yang dimisalkan seperti akar pohon yang kuat. Ketika keimanan itu tertanam kuat di dalam kalbu seorang muslim maka akan membuahkan perbuatan yang baik. ${ }^{18}$ Karena ketika seorang muslim mengikuti aqidah yang benar tentu perbuatannya akan sesuai dengan keyakinannya dan tidak berbuat kecuali sesuatu yang

\footnotetext{
${ }^{18}$ Abu Ja'far bin Jarir At-Thabari, Tafsir At-Thabari, Jami'u I-Bayan 'an Ta'Wil Ay l-Qur'an, 1st edn (Kairo: Dar Hijr, 2001). 13/634-636.
} 
benar. Melakukan sesuatu yang benar pasti akan bermanfaat bagi diri sendiri maupun orang lain.

Hal ini berbeda ketika manusia mengikuti aqidah yang salah, Allah memisalkannya seperti pohon yang tidak memiliki akar lagi buruk:

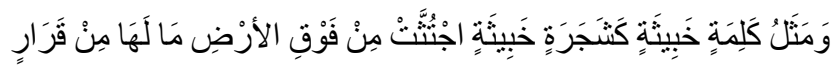

"Dan perumpamaan kalimat yang buruk seperti pohon yang buruk, yang telah dicabut dengan akar-akarnya dari permukaan bumi; tidak dapat tetap sedikitpun." (QS 14:26)

Menurut Ibnu Abbas, kalimat yang buruk adalah keyakinan yang menyekutukan Allah (syirik) ketika tertanam di dalam kalbu orang kafir. Hal ini akan menghasilkan perbuatan-perbuatan yang tidak menghasilkan manfaat, serta setiap amalannya tidak akan diterima oleh Allah di dunia dan di akhirat. ${ }^{19}$

Islam sebagai Din atau agama memiliki 3 aspek, yakni: 'Aqidah, Shari'ah dan Akhlaq. Aspek Aqidah merupakan yang paling fundamental dalam Islam, ia terangkum dalam "Kalimah Tayyibah" yang berisi kalimat Laa ilaaha illa Allah wa Muhammad Rasullullah, kalimat pertama merupakan kalimat pengikraran seorang hamba bahwa hanya Allah-lah Tuhan yang Satu, Pencipta dan Pengatur, Tuhan yang disembah dan Pemilik kesempurnaan nama dan sifat. Kalimat kedua berarti pengikraran bahwa Muhammad SAW adalah utusan-Nya kepada segenap manusia, ucapannya adalah wahyu ilahi, perilakunya adalah bentuk terbaik bagi kesempurnaan akhlaq. Mengikrarkan kalimat ini (as-syahadah) harus diucapkan dengan keyakinan yang teguh dan disertai dengan keikhlasan tanpa ada paksaan (laa ikraha fiid Diin). 19 At-Thabari, Tafsir At-Thabari, Jami'u I-Bayan 'an Ta'Wil Ay I-Qur'an.
13/655. 
Mengikrarkan kalimah tayyibah memiliki konsekuensi langsung bagi manusia dalam menjalani kehidupannya. Karena setelah berikrar ia harus merelakan dirinya (istislam) untuk menta'ati shari'ah islam yang termaktub dalam Al-Qur'an dan Al-Hadith. Shari'ah Islam berisi hukum-hukum (al-qanun), berupa perintah larangan dan rambu-rambu benar - salah tentang bagaimana manusia menjalani hidupnya. Kemudian seluruh hukum itu diatur dalam sistem reward and punishment jika ia ta'at akan memperoleh pahala, jika ingkar akan memperoleh dosa. Inilah diantaranya yang menjadi dorongan bagi seorang muslim untuk terus berperilaku dengan benar.

Orang mu'min pasti taat kepada Allah, namun jika ia melanggar perintah Allah maka pada saat itu ia tidaklah disebut mu'min yang sempurna, karena Iman berkaitan erat dengan ketaatan manusia kepada Allah. Rasullullah bersabda :

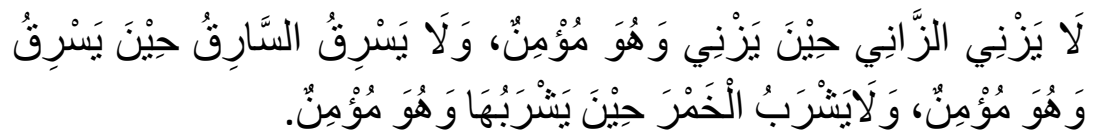

"Tidaklah berzina seorang pezina ketika ia berzina sedangkan dia seorang mu'min, dan tidaklah mencuri seorang pencuri ketika ia mencuri sedangkan dia mu'min, dan tidaklah meminum khamr dan ketika meminumnya dia adalah mu'min." 20

Jadi tidak boleh dikatakan "orang mu'min itu telah berzina" karena berzina adalah perbuatan bagi pezina bukan orang mu'min. Namun

20 Muhammad bin Ismail Abu Abdullah Al-Bukhari, Al-Jaami' Al-Sahiih Al-Mukhtashar Min Umuuri Rasuulillahi SWT Wa Sunanihi Wa Ayyaamihi, Sahih I-Bukhari, ed. by محمد زهير بن ناصر الناصر and Muhammad Zuhayr bin Naashir Al-Naashir, 1st edn (Damaskus: Daaru t-Tauqi n-Najaah, 2001) 3/136; Muslim, Al-Musnad Al-Sahih Al-Mukhtasar Bi Naqli I-Adli Mina I-Adli Ila Rasulillahi, ed. by Muhammad Fu'ad Abdu L-Baqi (Bairut: Daaru I-Ihya'u t-Turath Al-Arabi) 1/76. 
jika orang itu muslim namun melanggar perintah Allah, bisa jadi karena faktor tertentu, keimanannya berkurang dan dia melakukan apa yang dilarang oleh Allah.

Dengan melakukan yang benar, seorang muslim sebenarnya telah mendidik dirinya sendiri untuk menjadi pribadi yang berakhlaqul-karimah. Akhlaq disini berkaitan dengan 'karakter', 'etika' dan 'moral', ia berada pada aspek baik dan buruk. Jika ditinjau dari segi shari'ah, orang yang membunuh telah melanggar hukum, namun jika ditinjau dari segi akhlaq, orang yang membiarkan sampah atau bahaya yang ada di depannya sudah bermasalah secara etis.

Akhlaq merupakan bagian dari keimanan. Imam Al-Bayhaqi dalam kitabnya Al-Jami' li Shu'abil-Iman atau "kumpulan cabang-cabang Iman" menjelaskan tentang cabang-cabang keimanan yang tidak hanya berkaitan pada masalah keyakinan saja namun juga berkaitan dengan seluruh perilaku manusia dari bangun tidur hingga tidur kembali. ${ }^{21}$ Rasullullah SAW bersabda:

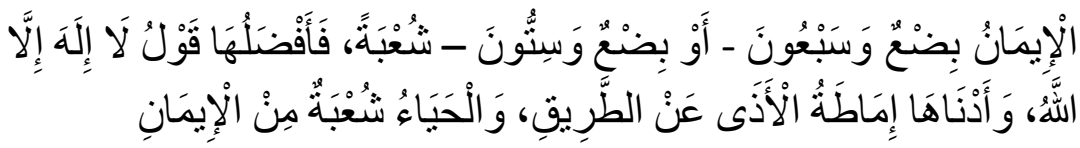

"Iman terdiri dari tujuh puluh lebih cabang keimanan, yang tertinggi adalah pernyataan "Laa Ilaaha Illa Allah" dan yang terrendah adalah menyingkirkan sesuatu yang berbahaya dari jalan, dan "sifat malu" adalah cabang dari iman". 22

Dalam Hadith lain juga disebutkan:

${ }^{21}$ Abu Bakar Ahmad bin Al-Husain Al-Bayhaqi, Al-Jami' Li s-Shu'abi I-Iman, ed. by Abdu I-Ali Abdul I-Hamid Hamid, 1st edn (Riyad: Maktabah Al-Rushd, 2003).

${ }^{22}$ Muslim 1/63. 


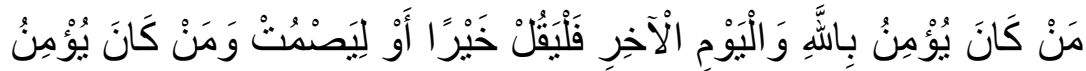

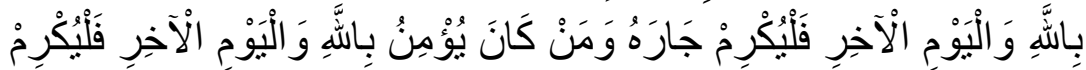
ضَنَفَْهُ

"Barang siapa yang beriman kepada Allah dan hari akhir maka ia akan berbicara yang baik atau diam, dan barang siapa yang beriman kepada Allah dan hari akhir maka akan menghormati tetangganya, dan barang siapa yang beriman kepada Allah dan hari akhir, maka akan menghormati tamunya.." ${ }^{23}$

Kedua hadith diatas menjelaskan bahwa keimanan seseorang terhadap aqidah Islam mengharuskannya untuk mengikuti segala konsekwensi yang mengikuti dari aqidah tersebut, karena mengimani saja tanpa mengikuti segala konsekwensinya berarti keimanan tersebut tidaklah sempurna.

Berikutnya buku ini akan fokus menelusuri hubungan antara aqidah dan akhlaq. Buku ini akan kami susun sebagai berikut: Bab 1 tentang hubungan antara aqidah dan akhlaq yang dijelaskan dalam berbagai wacana seperti jiwa manusia, tahsin wa taqbih, dan akhlaq tengah. Bab 2 tentang Ilahiyyat, atau aqidah ketuhanan dan implikasinya terhadap akhlaq. Bab 3 tentang Nubuwat, atau aqidah kenabian serta implikasinya terhadap akhlaq. Bab 4 tentang Sam'iyyat, atau aqidah tentang perkara-perkara yang hanya didengar melalui teks dan implikasinya terhadap akhlaq. Bab 5 tentang taqdir dan af'alu l-ibad serta implikasinya terhadap moral. Epilog: tentang pendidikan akhlaq dan pengaruhnya terhadap kebahagiaan manusia.

\section{BAB I}

WACANA AQIDAH DAN AKHLAQ

${ }^{23}$ Al-Bukhari 8/11; Muslim 1/68. 
Bab ini akan berbicara tentang hubungan aqidah dan akhlaq. Serta akan dijelaskan kaitan akhlaq dengan hukum, tradisi, jiwa manusia, tahsin dan taqbih, dan wacana akhlaq tengah.

\section{AQIDAH ISLAM}

Aqidah secara etimologi berasal dari kata 'aqada (عقد) artinya ikatan. ${ }^{24}$ Secara terminologi, menurut Dr 'Umar Sulaiman Al-Ashqari :

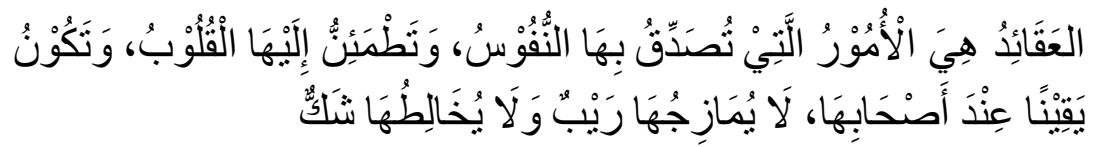

"Aqidah adalah perkara-perkara yang dibenarkan dengan jiwa, dengan membenarkannya hati menjadi tenang, dan orang yang membenarkannya benar-benar meyakininya tanpa bercampur keraguan sedikitpun."25

Kemudian perbuatan untuk meyakini sebuah aqidah disebut dengan "iman" yang didefinisikan sebagai:

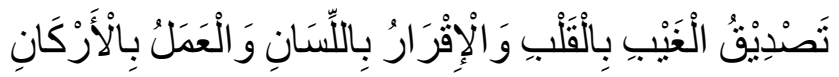

"Pembenaran perkara-perkara yang ghaib (aqidah) dengan kalbu/hati, dan diikrarkan dengan lisan dan dikerjakan dengan seluruh anggota tubuh."

Kemudian dalam sejarah keilmuan Islam berkembanglah "Ilmu Aqidah" yang disebut juga dengan berbagai nama; ilmu kalam, ilmu fiqhu l-akbar, ilmu ushulu d-din, dsbg. Ilmu Aqidah menurut Syeikh Husain Al-Wali adalah :

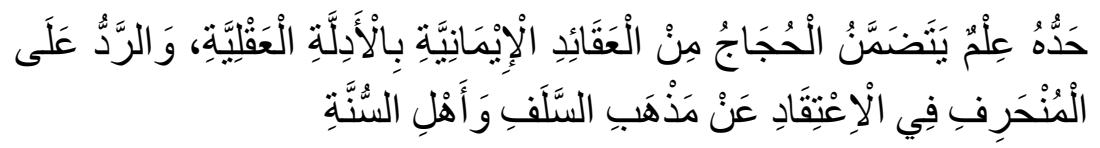

\footnotetext{
${ }^{24}$ Ibnu Mandzur, Lisaanu L-'Arab (Kairo: Daaru I-Ma'arif). 34/3031

${ }^{25}$ Umar Sulaiman Al-Ashqari, Al-'Aqidah 'Ala Dau'i I-Kitab Wa Sunnah, 12th edn (Jordan: Al-Nafaes, 1999).
} 
“Definisinya adalah IImu yang berisi argumentasi-argumentasi yang berkaitan dengan pembuktian Aqidah secara logis, dan menolak segala bentuk penyimpangan dari Aqidah Salafushalih (Sahabat, Tabi'in, Tabi'ut-Tabi'in, Atba'u t-Tabi'ut t-Tabi'in) atau Aqidah Ahlu s-Sunnah."26

Ilmu Aqidah berfungsi untuk membuktikan, menetapkan, dan membela Aqidah Islam dari berbagai tantangan terhadapnya, baik dari luar ataupun dalam Islam. Maka dengan mempelajari ilmu aqidah manusia mampu membedakan antara aqidah yang benar dan yang salah, sehingga ia akan semakin yakin dengan aqidah yang benar. aqidah yang benar yakni aqidah yang berasal dari Allah SWT diturunkan kepada para rasul-Nya, aqidah ini disebut ad-dinu I-hanif (الأدِّيْنُ الْحَنْيْفُْ atau agama yang lurus (Ar-Rum: 30). Sedangkan aqidah yang rusak adalah aqidah yang berasal dari tradisi-tradisi dan pemikiran manusia. Aqidah semacam ini bisa jadi berasal dari aqidah yang benar namun berubah karena adanya penyimpangan oleh manusia. Pada masa ini tidak ada aqidah yang benar kecuali aqidah Islam, karena ajaran Islam merupakan agama yang diturunkan oleh Allah sebagai penyempurna dan penghapus ajaran sebelumnya (Al-Ma'idah: 48, Al-Baqarah: 134). ${ }^{27}$

Aqidah Islam sebagaimana ajaran Islam yang lainnya, bersumber dari Al-Qur'an dan As-Sunnah. Keduanya merupakan sumber utama bagi ajaran agama Islam secara keseluruhan. Karena Al-Qur'an adalah kalam Allah yang diturunkan kepada Nabi Muhammad SAW :

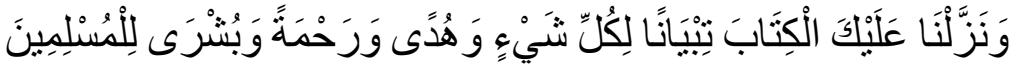

\footnotetext{
26 Husain Al-Wali, Kitab Kalimatu T-Tauhid, 1st edn (Mesir: Maktabah Al-Wa'idz, 1908). 17

${ }^{27}$ Al-Ashqari, Al-'Aqidah 'Ala Dau'i I-Kitab Wa Sunnah. 1/14
} 
"Kami turunkan kepadamu Al-Kitab (Al-Qur'an) untuk menjelaskan segala sesuatu dan petunjuk serta rahmat dan kabar gembira bagi orang-orang yang berserah diri. (An-Nahl: 89)."

Sedangkan As-Sunnah merupakan ucapan dan perbuatan nabi Muhammad SAW, As-Sunnah adalah penjelas bagi Al-Qur'an, Allah berfirman:

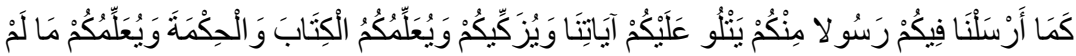

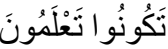

"Sebagaimana (kami telah menyempurnakan nikmat Kami kepadamu) Kami telah mengutus kepadamu Rasul diantara kamu yang membacakan ayat-ayat Kami kepada kamu dan mensucikan kamu dan mengajarkan kepadamu Al-Kitab (Al-Qur'an) dan Al-Hikmah (Al-Sunnah), serta mengajarkan kepada kamu apa yang belum kamu ketahui." (Al-Baqarah: 151)

Mendasarkan Aqidah Islam harus berdasarkan Al-Qur'an dan Al-Hadits tidak boleh hanya berdasarkan akal dan perasaan semata. Karena boleh jadi apa yang dikira sebagai "kebenaran" ternyata bukanlah kebenaran (Al-Mu'minun: 71) .Namun Al-Qur'an juga banyak memberikan isyarat pentingnya penggunaan akal sebagai salah satu sarana mencapai kebenaran. Bahkan banyak ayat menyebutkan bahwa dengan melihat dan memikirkan berbagai peristiwa di alam semesta ternyata membawa manusia lebih meyakini Rabbnya (Al-Baqarah: 164, Ali Imran: 190). Dengan demikian penggunaan akal tidak lain adalah sebagai bentuk "pembenaran" terhadap Aqidah Islam yang telah termaktub di dalam Al-Qur'an dan Al-Hadith. Karena ada perkara Aqidah yang bisa difikirkan dengan akal, semisal perkara llahiyyat dan Nubuwwat, namun ada perkara ghaib yang tidak mungkin diketahui dengan Akal, semisal perkara Sam'iyyat. Maka, boleh menggunakan akal dengan syarat tidak boleh menyimpang dari apa yang sudah ditetapkan dalam Al-Qur'an dan As-Sunnah. 
Para 'Ulama' membagi ruang lingkup Aqidah Islam kedalam tiga bagian: ${ }^{28}$

Pertama: Al-llahiyyat atau ketuhanan, hal ini membahas tentang Allah SWT dan segala perbuatan, nama dan sifat-Nya serta berbagai perkara yang harus diyakini bagi setiap manusia.

Kedua: An-Nubuwat, hal ini membahas segala yang berkaitan dengan para nabi dan rasul, mulai dari sifat, keterjagaan mereka dari dosa ('ismah) dan urgensi dari pengutusan mereka. Hal ini juga berkaitan dengan pembahasan seputar para wali Allah, mu'jizat, karamah dan kitab-kitab langit.

Ketiga: As-Sam'iyyat - Al-Ghaibiyyah, hal ini berkaitan dengan hal-hal yang hanya bisa didengar dan diketahui melalui teks dan tidak bisa dibuktikan dengan panca indera dan logika rasional diantaranya: berkaitan dengan kehidupan setelah mati; alam barzakh, keadaan dikubur, tanda-tanda kiamat, hari kiamat, hari kebangkitan, perhitungan amal, pembalasan, malaikat, jin dan ruh dsb. ${ }^{29}$

Ruang lingkup yang tiga ini juga terangkum dalam rukun Islam, sebagaimana yang di dalam Hadith, ketika Nabi Muhammad SAW ditanya oleh Jibril tentang definisi Iman:

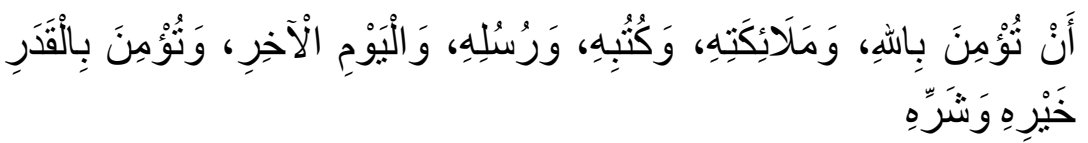

Yakni: "Beriman kepada Allah, malaikat-Nya, kitab-Nya, rasul-Nya, hari akhir dan qada' - qadar." (HR. Bukhari). ${ }^{30}$

28 Hasan Ayub, Tabsit L-Aqa'id I-Islamiyyah, 5th edn (Beirut: Daaru n-Nadwah al-Jadidah, 1983). P.23

${ }^{29}$ Muhammad 'Aqil Bin 'Ali Al-Mahdili, Dirasatun Fi L-Sam'iyyat, 1st edn (Kairo: Dar I-Hadits, 1996). P.7

30 PP Muhammadiyah, Himpunan Putusan Tarjih Muhammadiyah (HPT) (Yogyakarta: Suara Muhammadiyah, 2011). P.12-13 


\section{AKHLAQ}

Nabi Muhammad SAW mendeklarasikan dalam sebuah hadithnya "sesungguhnya aku diutus tidak lain, untuk menyempurnakan akhlaq yang baik (مكارم الأخلاق)." Kata "menyempurnakan" menunjukkan bahwa manusia sebelum Islam turun, telah mengetahui tentang akhlaq yang baik, mereka mampu membedakan baik dan buruk. Namun seringkali "kebaikan dan keburukan" menjadi ambigu, disebabkan oleh ego dan nafsu yang mengalahkan akal sehat, sehingga keduanya bercampur satu dengan yang lainnya. Maka, tanpa otoritas yang kuat, ukuran, dan batas "baik dan buruk" menjadi kacau, disebabkan karena perbedaan fikiran masing-masing orang. Oleh karenanya dengan diutusnya Nabi Muhammad SAW tidak lain adalah untuk mempertegas apa yang disebut dengan akhlaq yang baik dan akhlaq yang buruk, serta mengajarkan apa yang belum diketahui oleh manusia.

“Akhlaq" merupakan kata berbahasa Arab (الأَخْلَقُقُ ) bentuk plural dari khuluq (الخُلْقُ). Kata "akhlaq" jika diderivasikan maka ia berasal dari 3 huruf jika digabungkan menjadi bentuk kata kerja خَلَقَ yang memiliki beberapa arti, antara lain: menciptakan tanpa ada misal sebelumnya (أَبْدَعَهُ مِنْ غَيْرِ مِثَالِ سَابِقِ), menentukan

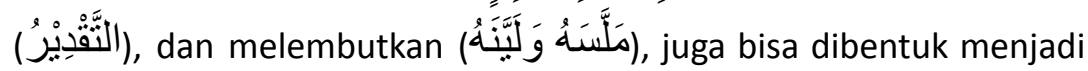
kata (الخِلْقَةُ berarti fitrah (الفِطَرَ) atau sifat alamiah manusia. ${ }^{31}$

\footnotetext{
${ }^{31}$ Mandzur; Muhammad Murtadha Al-Husaini Al-Zabidi, Taaju L-'Aruus Min Jawahiri I-Qamus, ed. by Musthafa Hijazi, 2nd edn (Kuwait: Matba'ah Hukumah Kuwait, 1987); Isma'il Bin Hammad Al-Jawhari, Al-Sihhah, Taaj Ul-Lughah Wa Sihhahu I-Arabiyyah, ed. by Ahmad Abdul Ghafur Al-Attar, 4th edn (Beirut: Daaru I-Alam li I-Malayiin, 1990).
} 
Sedangkan kata khuluq (الخُلُقُُ ) sebagaimana yang disebutkan oleh Ibnu Mandzur:

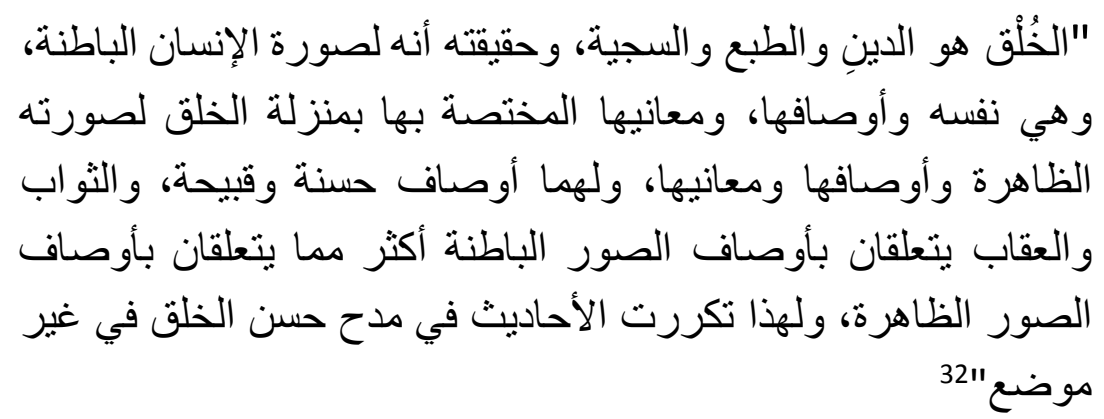

Terjemahan bebasnya: Khuluq diartikan lebih jauh adalah agama (الدينِ), watak alamiah (الطبع), dan karakter (السجية) hakekatnya ia adalah gambaran manusia yang batin; atau hakekatnya adalah diri/jiwa manusia itu dan sifat-sifatnya. Makna hakekat khuluq yang lebih khusus menunjukkan bentuk yang zahir (dalam perilaku dan perbuatan), sifat-sifatnya dan makna-maknanya. Khuluq pada makna batin dan zahir memiliki sifat baik dan buruk, pahala dan hukuman, keduanya lebih banyak berkaitan dengan sifat-sifat yang batin, ketimbang dengan sifat yang zahir, itulah mengapa banyak dalam hadith memuji akhlaq yang baik namun tidak pada perbuatan zahirnya.

Melalui penelusuran ini ada beberapa rangkaian makna yang saling berkaitaan antara lain menciptakan, menentukan, melembutkan, agama, watak alamiah, tabi'at, karakter. Jika kata-kata itu dikaitkan mungkin untuk dikatakan bahwa apa yang diciptakan oleh Allah atau "makhluq" pada dasarnya telah ditetapkan dalam dirinya tabi'at dan watak dasar (الخِلْقَةُ/الفِطْرَةُ) yang diciptakan bersamaan dengan penciptaan dirinya. Begitu juga dengan manusia,

\footnotetext{
${ }^{32}$ Mandzur.
} 
sesungguhnya ia telah diciptakan dengan sifat alamiah yang mengikutinya yang disebut dengan "fitrah".

Berdasarkan pendefinisian diatas dapat dipahami bahwa khuluq adalah karakter atau watak. Lebih jauh lagi definisi khuluq dapat dilihat dalam definisi para ulama'. Ibnu Miskawaih dalam kitab tahdzibu l-akhlaq wa tathiru l-a'raq, mendefinisikan:

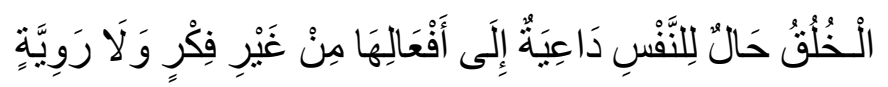

Terjemahan bebasnya: "Akhlaq adalah keadaan jiwa yang mendorong terjadinya perbuatan tanpa perlu berfikir dan tanpa usaha atau direncanakan sebelumnya". ${ }^{33}$ "Keadaan jiwa" yang dimaksud oleh Ibnu Miskawaih bisa juga diartikan, sebagaimana yang juga didefinisikan oleh Imam Al-Ghazali, sebagai هيئة النفس atau watak atau perangai dari jiwa yang terwujudkan dalam sebuah perbuatan "tanpa berfikir dan usaha" atau perbuatan yang terjadi secara spontan, Misalkan ketika ada orang yang marah-marah hanya karena suatu yang kecil terjadi padanya, atau orang yang bersabar walaupun telah tertimpa suatu kejadian yang besar kepadanya. Perilaku yang muncul secara langsung itulah yang disebut dengan akhlaq. Namun jika orang yang marah itu kemudian meredam amarahnya, sehingga ia menjadi tenang, ketenangan itu bukan akhlaqnya, karena ia menjadi tenang setelah berfikir dan berusaha untuk menjadi tenang.

Jika watak tersebut menghasilkan perbuatan yang terpuji maka watak tersebut disebut akhlaq yang baik, namun apabila watak itu menghasilkan perbuatan yang buruk, maka watak itu disebut akhlaq yang buruk, Imam Al-Ghazali menyebutkan:

${ }^{33}$ Ibnu Miskawaih, Tahdzibu L-Akhlaq Wa Tathiru I-A'raq, 1st edn (Beirut: Daaru I-Kutub, 1985). 
"فإن كانت الهيئة بحيث تصدر عنها الأفعال الجميلة المحمودة عقلا

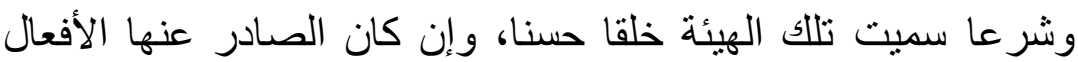
القيحة سميت الهيئة التي هي المصدر خلقا سيئا"

Terjemahan bebasnya: "dan apabila watak itu memunculkan perbuatan yang bai ditinjau dari akal ataupun syari'at, maka watak itu disebuut akhlaq yang baik, dan apabila yang keluar adalah perbuatan yang buruk maka watak tersebut disebut dengan akhlaq yang buruk. ${ }^{34}$

Sedangkan etika dan moral dalam Bahasa Inggris "ethics" dan "moral", dan Bahasa Yunani, "ethos" dan "moralis", dalam penggunaannya diartikan sinonim; atau etika adalah moral itu sendiri dan sebaliknya. Disebutkan dalam "Oxford: Fowlers Modern English Usage" bahwa ethics adalah ilmu tentang moral-moral, dan moral adalah praktek dari etika. Terkadang dalam pemaknaannya orang menggunakan kata-kata etika dan moral sebagai sesuatu yang berbeda, seperti ucapan: "yang dilakukannya mungkin etis, namun tidak bermoral." Namun pada dasarnya kedua-duanya memiliki makna yang sama, dan penggunaannya selalu saling dipertukarkan. ${ }^{35}$

\section{AKHLAQ-TRADISI-HUKUM-SYARI'AH}

Pertanyaan mendasar dari diskusi ini adalah: "bagaimanakah akhlaq berkontribusi bagi terbentuknya hukum?", dan "bagaimanakah pengaruh tradisi dalam terbentuknya hukum dan akhlaq?"

\footnotetext{
${ }^{34}$ Abu Hamid Muhammad bin Muhammad Al-Ghazali, Ihya' Ulumuddin, 1st edn (Beirut: Daar Ibnu Hazm, 2005).

${ }^{35}$ H.W. Fowlers, Oxford Fowler's Modern English Usage, ed. by Sir Ernest Gower, 2nd edn (Oxford: Oxford University Press, 1985).
} 
Hukum dalam Bahasa Arab الحكم، القضاء، القانون، الدسنور dan dalam Bahasa Inggris law dan canon. Yakni suatu peraturan dan prinsip-prinsip yang memiliki otoritas untuk menentukan suatu perkara, yang dideklarasikan oleh sekelompok orang yang bertanggungjawab untuk menciptakan tata tertib yang baik dalam sebuah komunitas, tata tertib itu ditetapkan dan diselenggarakan untuk harus ditaati, dan petunjuk bagi perbuatan anggota dalam komunitas yang otoritatif. Masyarakat dalam suatu kontrak sosial tertentu harus mengikuti hukum yang ada dan diciptakan agar menciptakan keteraturan, kebaikan, dan keadilan bagi masyarakat tersebut. ${ }^{36}$ Hukum bersifat mengikat, maka diskusinya bukan hanya seperti akhlaq yang berbicara pada wilayah baik dan buruk, namun pada apa yang menjadi keharusan/ obligation/ wajib, apa yang boleh/ legal/ halal/ mubah dan apa yang dilarang/ forbidden/ prohibited/ haram. Legal secara hukum belum tentu baik menurut akhlaq, begitu pula yang buruk menurut hukum belum tentu buruk menurut akhlaq. Ketika suatu negara melegalkan porstitusi, bukan berarti kegiatan itu menjadi baik secara akhlaq.

Walaupun berbeda namun hukum dan akhlaq juga memiliki keterkaitan. Ketika hukum melarang pencurian, pembunuhan, dsbg, karena mencuri dan membunuh adalah perbuatan yang buruk secara akhlaq. Namun akhlaq yang mempengaruhi hukum berbeda antara satu ideologi atau agama dengan lainnya, tergantung keyakinan yang diikuti oleh kelompok pembuat hukum. Hukum sekular di Perancis, misalkan, memiliki prinsip etisnya yang disebut: laïcité yakni prinsip yang menjunjung equalitas dan netralitas liberal, salah satu upayanya adalah melarang penggunaan simbol-simbol keagamaan di ruang

\footnotetext{
${ }^{36}$ Ted Honderich, The Oxford Companion to Philosophy, 2nd edn (Oxford: Oxford University Press, 2005). P.497
} 
publik termasuk hijab yang dikenakan oleh kaum muslim. ${ }^{37}$ Sedangkan di beberapa negara di timur tengah mempraktikkan qisas, diantaranya hukuman rajam bagi pezina dan potong tangan bagi pencuri, model hukuman semacam ini dalam kacamata humanisme Barat sangatlah buruk karena tidak manusiawi. ${ }^{38}$

John Rawls, salah seorang pemikir liberal kontemporer, menyebutkan bahwa hukum suatu masyarakat dan negara harus memuaskan semua ideologi dan agama, atau hukum itu harus berdiri di atas ideologi, agama, keyakinan, suku, ras, dan hal-hal yang menyebabkan terjadinya perselisihan dalam suatu masyarakat. Hukum baginya harus netral, ketika memposisikan dirinya diantara banyaknya subjektivitas worldview ideologi dan agama. Maka hukum, menurutnya, harus memiliki prinsip persamaan (equality), bebas (free), dan masuk akal (rational). ${ }^{39}$ Namun menafikan subjektifitas dalam menetapkan hukum adalah suatu hal yang tidak mungkin dilakukan, karena ide menafikan subjektifitas adalah ideologi itu sendiri dan subjektifitas itu sendiri. Perancis ingin melakukan itu, namun keinginan berdiri diatas semua agama dan ideologi justru menunjukkan bahwa prinsip hukumnya adalah ideologi sekuler, yang memarginalkan agama dalam urusan dunia.

Sedangkan dalam Islam hukum dan akhlaq dituntun oleh Syari'at Islam, yakni prinsip-prinsip dan peraturan terkait dengan keyakinan, hukum, dan akhlaq yang diturunkan Allah kepada Nabi Muhammad SAW. Rajm tanpa diragukan lagi termasuk syari'at Islam, yakni hukuman lempar batu bagi pezina (pelaku hubungan seks di

${ }^{37}$ Cécile Laborde, Critical Republicanism: The Hijab Controversy and Political Philosophy, 1st edn (New York: Oxford University Press, 2008). P. 32-...

${ }^{38}$ Lihat tulisan Nonie Darwish, Cruel and Usual Punishment (Nashville: Thomas Nelson.Inc, 2008). Akan terlihat kebencian terhadap shari'ah Islam.

${ }^{39}$ Michael J. Perry, Morality, Politics, and Law, 1st edn (New York: Oxford University Press, 1998). P. 57- ... 
luar pernikahan) yang sudah pernah menikah (muhsan). Islam memerangi perzinahan karena, menurut Yusuf Qardawi, mengakibatkan percampuran keturunan, kejahatan terhadap anak, tercerai berainya keluarga, rusaknya hubungan, tersebarnya penyakit, bergejolaknya syahwat, dan yang terakhir hancurnya akhlaq. ${ }^{40}$ Melihat bahaya dari perzinahan penegakkan hukum rajm bukanlah hal yang kejam. Selain itu prosesi pelaksanaan rajm dalam Islam sangatlah ketat, sehingga tidak bisa semua orang yang tertuduh berzina dirajam, kecuali jika bukti-buktinya sudah jelas.

Maka, hukum dan akhlaq yang ditetapkan, dipraktikkan, dan diyakini di suatu masyarakat tertentu, tidak bisa terlepas dari worldview-nya.

Hukum dan akhlaq juga memiliki keterkaitan dengan tradisi suatu masyarakat. Tradisi dalam Bahasa Arab العادة berarti sesuatu yang diketahui (العرف) disebutkan lebih lanjut oleh Al-Zabidi, ia adalah suatu jalan, atau hal tertentu yang diulangi terus-menerus tanpa ada relasi dengan akal. ${ }^{41}$ Dalam bahasa Inggris disebut tradition merupakan sekumpulan keyakinan atau jalan yang tidak memiliki sumber yang pasti, namun diterima tanpa direfleksikan (oleh yang menerima tradisi) sebagai sesuatu yang benar, atau bahkan diterima memiliki otoritas untuk menentukan suatu hal. ${ }^{42}$ Berdasarkan definisi diatas dapat disimpulkan bahwa tradisi atau adat adalah sesuatu yang diyakini tanpa difikirkan, sumbernya tidak jelas, namun memiliki kekuasan dalam menentukan sesuatu dalam masyarakat.

40 Yusuf Qardawi, Al-Halal-Wa I-Haram Fi I-Islam, 22nd edn (Kairo: Maktabah Wahbah, 1997). P.134.

${ }^{41}$ Al-Zabidi. Vol. 8. P. 443

${ }^{42}$ Honderich. P. 922 
Sebuah tradisi bisa jadi muncul dari mitos. Tradisi semacam ini biasanya muncul dari folkore atau cerita rakyat, kemudian orang akan menciptakan bentuk ritual khusus. Atau melalui cerita-cerita itu kemudian orang mengambil suatu nilai moralitas yang mengikat bagi masyarakat tersebut. ${ }^{43}$ Keyakinan-keyakinan itu tidak memiliki dasar apapun, dan tidak pernah difikirkan secara logis oleh yang meyakininya.

Kebiasaan berpakaian juga merupakan tradisi. Tradisi yang demikian ini selalu berubah dan tidak pasti, selalu mengikuti gaya zamannya. Tradisi baju yang resmi digunakan ketika perkumpulan di sebuah perusahaan untuk pria adalah menggunakan pakaian disertai jas dan dasi. Mengenai tradisi pakaian, ada pertanyaan dalam hukum Islam, apa hukumnya shalat tanpa menggunakan penutup kepala? Para ulama' berbeda pendapat ada yang memakruhkan, ada pula yang memperbolehkannya karena tidak masuk rukun atau syarat shalat. Problemnya karena Rasullullah dalam shalatnya selalu menggunakan penutup kepala, namun tidak ada satupun hadith yang menunjukkan bahwa Rasullullah mewajibkan atau mensunnahkan umatnya untuk menutup kepala saat shalat. Hal ini sebenarnya menjelaskan bahwa menggunakan penutup kepala adalah tradisi Arab pada masa itu, tidak berkaitan dengan rukun dan syarat sahnya shalat.

Walaupun hanya sekedar tradisi, penggunaan penutup kepala jika menjadi keharusan dalam suatu masyarakat, maka harus diikuti. Di Madura, sebagaimana yang diungkapkan oleh Hamka, jika ada orang yang shalat tidak menggunakan peci di Madura, ia akan

\footnotetext{
${ }^{43}$ Martha C. Sims, Living Folklore: An Introduction to the Study of People and Their Traditions (Logan, Utah: Utah State University Press, 2005).
} 
mendapatkan teguran keras, bahkan dilempari batu. ${ }^{44}$ Disini tidak menggunakan peci ketika shalat bagi masyarakat Madura adalah hal yang buruk. Jika demikian penggunaan peci menjadi harus untuk dilakukan untuk mengikuti dan menghormati tradisi setempat. Mengenai pembicaraan mengenai adat, dalam Islam terdapat kaedah "العادة محكمة" atau tradisi atau adat dapat berlaku menjadi hukum, selama tidak bertentangan dengan syari'at. ${ }^{45}$

\section{AQIDAH DAN AKHLAQ DALAM JIWA MANUSIA}

Berdasarkan definisi aqidah dan akhlaq sebagaimana yang disebutkan sebelumnya, keduanya memiliki kesamaan yakni tempat keduanya ada di dalam jiwa. Pada pembahasan ini akan dijelaskan tentang bagaimana aqidah mempengaruhi akhlaq di dalam jiwa manusia, sehingga memunculkan sebuah perbuatan.

Jiwa dalam Bahasa Arab adalah نَفْ dalam Bahasa Inggris bisa diartikan sebagai "self" atau diri. Pertanyaannya kemudian apakah jiwa itu benar-benar ada? Imam Fakhruddin Ar-Razi dalam kitab Al-Nafs wa Al-Ruh wa Jami'u Quwaha ${ }^{46}$ membuktikan bahwa jiwa itu bukan badan manusia. la berargumentasi bahwa tubuh manusia tidak disifati dengan melihat, mendengar, mengetahui, berbicara dsbg. Bukan hanya karena memiliki mata seseorang dapat melihat, karena ada orang yang memiliki mata tapi tidak bisa melihat. Juga bukan karena otak dan jantung orang bisa mengetahui

\footnotetext{
${ }^{44}$ Hamka, Dari Perbendaharaan Lama, 2nd edn (Jakarta: Pustaka Panjimas, 1982).

${ }^{45}$ Lihat di Ya'qub bin Abdu L-Wahhab, Qo'idah 'Al-'Adah Muhakkamah': Dirasah Ta'siliyyah, Tatbiqiyyah, 2nd edn (Riyad: Maktabah Rusyd, 2012).

${ }^{46}$ Fakhru d-Din Muhammad bin Umar Al-Razi, Kitabu N-Nafsi Wa r-Ruhi Wa Sharhu Quwaha, ed. by Muhammad Shagir Al-Ma'shumi (Islamabad-Pakistan: Ma'had Al-Abhath Al-Islamiyyah). P.30
} 
tapi ada sesuatu yang non-fisik yang dapat mengetahui. Seseorang berkata; aku melihat, aku mendengar, aku tahu, aku ingin, seluruh hal tersebut tidak digerakkan oleh badan tetapi sesuatu selain badan. Ibnu Bajah juga menyebutkan bahwa tubuh yang bergerak pasti ada yang menggerakkan, tidak mungkin ia dapat bergerak dengan sendirinya. Oleh karenanya ada sesuatu yang menggerakkannya selain tubuh itu sendiri. Itulah jiwa. Oleh karenanya jiwa didefinisikan sebagai penyempurna tubuh, karena tubuh tidak bisa hidup kecuali jika memiliki jiwa. ${ }^{47}$

Lebih lanjut Ibnu Sina dalam Kitab Al-Shifa': Al-Tabi'iyyat berargumentasi untuk membuktikan eksistensi jiwa. la mengajak kita bermeditasi dengan memejamkan mata dan menghalangi berbagai pandangan luar kedalam diri kita. Kemudian kita membayangkan bahwa sebenarnya kita ini diciptakan berterbangan di udara tidak memijak ketanah dan tidak ada apapun di sekeliling kita, baik di atas, bawah, depan, dan belakang. Kemudian kita bayangkan bahwa panca indera kita tidak lagi berfungsi, kita tidak bisa merasakan apapun bahkan kita tidak bisa merasakan mata, kaki, tangan, jantung bahkan otak. Pada saat itu tidak ada lagi selain "aku" atau "diriku". Maka kita akan tahu pada saat itu bahwa "diriku" itu ada bukan karena anggota tubuh, "diriku" terpisah dari anggota tubuh, atau "diriku" adalah sesuatu yang lain dari tubuh. ${ }^{48}$ "Diriku" yang ingin dijelaskan Ibnu Sina inilah yang disebut dengan jiwa.

Argumentasi Ibnu Sina ini kemudian diikuti oleh filosof Barat abad pencerahan Rene Descartes yang terkenal dalam karyanya

\footnotetext{
${ }^{47}$ Abu Bakar Muhammmad Bin Bajah, Kitab An-Nafs, ed. by Muhammad Shaghir Hasan Al-Ma'shumi, 2nd edn (Beirut: Daar Shadir, 1992).

${ }^{48}$ Ibnu Sina Avicenna and Fadlur Rahman, Avicenna's De Anima (Arabic Text) Being The Psychological Part of Kitab Al-Shifa', ed. by Fadlur Rahman (London: Oxford University Press, 1959).
} 
Meditation setelah menghilangkan semua hal yang ada, namun ada satu hal yang tidak bisa ia hilangkan yaitu aku yang berfikir; "Aku ada, itu pasti. Tapi hingga kapan? Pastinya selama aku berfikir. Atau jika aku berhenti dari semua kegiatan berfikir mungkin pada saat itu juga aku berhenti ada." Descartes ingin menunjukkan bahwa selama "aku berfikir maka aku ada." Pernyataan ini menunjukkan bahwa kesadaran manusia terhadap dirinya adalah kesadaran manusia akan eksistensi dirinya. Menyadari eksistensi diri adalah perbuatan jiwa. ${ }^{49}$

Jiwa mencakup kesadaran manusia terhadap dirinya sendiri dan juga kesadaran manusia terhadap yang lainnya. Karena adanya kesadaran maka manusia memiliki keinginan dan kehendak dan dari keduanya muncullah tindakan. Munculnya keinginan dan kehendak disebabkan karena ada dorongan dari dalam jiwa, atau tergantung pada keadaan jiwa tersebut. Keadaan yang ada dalam jiwa dapat berubah-rubah, perubahan itu dikarenakan reaksi terhadap suatu hal yang datang dari luar jiwa, seperti orang yang tertimpa musibah menciptakan keadaan jiwa yang sedih atau mungkin keadaan jiwa yang marah.

Di dalam jiwa juga terdapat potensi-potensi yang dapat menjadi faktor penentu munculnya keinginan dan kehendak dari

49 Descartes berkata: "I will think that the sky, the air, the earth, colours, shapes, sounds, and all external things are no different from the illusions of our dreams, and that they are traps he has laid for my credulity; I will consider myself as having no hands, no eyes, no flesh, no blood, and no senses, but yet as falsely believing that I have all these What about thinking? Here I do find something: it is thought; this alone cannot be stripped from me........ I am, I exist, this is certain. But for how long? Certainly only for as long as I am thinking; for perhaps if I were to cease from all thinking it might also come to pass that I might immediately cease altogether to exist." René Descartes, Meditation on First Philosophy With Selections from the Objections and Replies, ed. by Michael Moriarty, 1st edn (New York: Oxford University Press, 2008). P.19. 
dalam diri manusia. Potensi-potensi itu sebagaimana yang disebutkan oleh Imam Al-Ghazali dalam Ihya', antara lain: Potensi rasional, potensi amarah, potensi syahwat dan potensi untuk bersikap adil dari ke-3 potensi lainnya. ${ }^{50}$ Maksud dari potensi adil disini adalah potensi untuk memposisikan sesuatu pada porsinya tidak berlebihan dan tidak kurang. Terkadang dalam diri manusia memiliki salah satu potensi yang unggul ketimbang yang lainnya. Jika yang unggul adalah potensi amarah maka orang tersebut akan mudah sekali marah-marah terhadap hal-hal yang kecil, atau jika yang unggul adalah potensi syahwatnya maka dia akan selalu suka memenuhi kebutuhan perut dan seksualnya. Agar potensi-potensi tersebut dapat memunculkan akhlaq yang baik, menurut Al-Ghazali amarah dan syahwat harus tunduk dibawah potensi rasional dan potensi keadilan sehingga dapat diposisikan berdasarkan porsinya. Jika potensi amarah berada pada porsinya yang benar maka akan memunculkan keberanian, dan jika potensi syahwat berada pada porsinya yang benar maka akan menjadi kebaikan dan pengendalian $\operatorname{diri}(ع ف)$ (ع)

Jiwa dalam diri tiap orang itu satu, bukan dua atau lebih, karena jika jiwa ada dua maka "aku yang melihat", "aku yang mendengar", "aku yang mengetahui" adalah substansi sendiri-sendiri. "Aku yang melihat", "aku yang mendengar", dan "aku yang mengetahui" adalah satu kesatuan. Seseorang melihat dan mendengar kemudian mengetahui, seseorang yang telah mengetahui akan menimbulkan respon yang bermacam-macam ada yang marah, ada yang benci, dan ada pula yang menginginkan. Orang yang marah,

${ }^{50}$ Al-Ghazali. 935 
yang benci, dan yang menginginkan adalah satu namun berbeda dalam respon dan perilaku tergantung pada kondisi tertentu. ${ }^{51}$

Karena jiwa itu satu, maka letak aqidah dan akhlaq juga pada tempat yang satu. Ketika manusia mengetahui bahwa Allah itu adalah satu-satunya Tuhan dan Nabi Muhammad adalah utusan-Nya, kemudian meyakini hal itu dengan segenap kalbunya, maka secara otomatis akan menghasilkan respon-respon dalam jiwanya dan memberikan pengaruh dalam tingkah lakunya.

\section{TAHSIN WA TAQBIH}

Wacana Tahsin wa Taqbih bermula dari pertanyaan meta-etis tentang "bagaimanakah cara kita mengetahui kebaikan dan keburukan?" atau "apa yang menjadi ukuran dalam menentukan kebaikan dan keburukan?" Bagi kelompok relativis akan mengatakan bahwa ukurannya adalah manusia, sebagaimana ungkapan kaum sofis "apa yang bagi manusia baik adalah baik dan apa yang bagi manusia buruk adalah buruk", jika demikian maka tidak ada ukuran pasti dalam moralistas. ${ }^{52}$ Sedangkan bagi seorang Muslim nilai baik dan buruk adalah pasti, namun bagaimanakah kebaikan dan keburukan dapat diketahui?, apakah melalui akal atau teks Al-Qur'an dan Al-Hadith?

Kelompok Mu'tazilah berkeyakinan bahwa kebaikan dan keburukan dapat diketahui dengan akal. Argumentasinya bahwa ada nilai etis yang dapat diketahui dengan akal secara apriori, misalkan:

\footnotetext{
${ }^{51}$ Fakhru d-Din Muhammad bin Umar Al-Razi. P. 27

${ }^{52}$ Bertrand Russel, History of Western Philosophy and Its Connection With Political and Social Circumstances From the Earliest Times to The Present Days, 2nd edn (New York: George Allen and Unwin LTD, 1949).
} 
mencuri itu buruk, bersedekah itu baik dsbg. Selain itu menurut Mu'tazilah akal juga mampu mengetahui kebaikan dan keburukan dengan penalaran dan pembuktian. Ukurannya jika sesuatu itu memiliki manfaat dan maslahat maka ia adalah baik namun jika ia memiliki bahaya maka ia adalah buruk. Misalkan tentang bagaimanakah shalat itu disebut baik? Maka dapat dijawab shalat disebut baik karena mencegah dari buruk dan keji. ${ }^{53}$

Pendapat Mu'tazilah ini ditolak oleh kelompok Asya'irah, Imam Juwaini misalkan menolak bahwa kebaikan dan keburukan dapat diketahui dengan akal. Alasannya karena tidak semua orang bersepakat dengan kebaikan dan keburukan lainnya, misalkan tentang kenabian Nabi Muhammad Saw, bagi orang kafir itu adalah sesuatu yang buruk, namun bagi seorang muslim itu adalah sesuatu yang baik. Maka untuk mengetahui baik dan buruk hanya dapat melalui teks atau Al-Qur'an dan Al-Hadith. Apa yang dikatakan teks sebagai baik maka ia baik, begitu pula sebaliknya. ${ }^{54}$ Atau jika ditinjau dari al-ahkam at-taklifiyyah kebaikan dapat dilihat sebagai yang wajib, sunnah, dan mubah, dan sesuatu yang buruk adalah sesuatu yang dibenci dan diharamkan. ${ }^{55}$

Namun perlu diketahui bahwa Allah Swt dalam Al-Qur'an dan Nabi Muhammad Saw dalam hadithnya berkali-kali menyerukan agar manusia menggunakan akalnya. Hal ini menunjukkan bahwa

${ }^{53}$ Ayid bin Abdullah bin Abdu I-'Aziz Al-Syahrani, At-Tahsin Wa At-Taqbih Aqliyani Wa Atharuhuma Fii Masaa'ili Ushuli I-Fiqh Ma'a Munaqashah Al-'Ilmiyyah Li Ushuli I-Madrasah Al-'Aqliyyah Al-Hadithah, 1st edn (Riyad: Daaru I-Kunuz Ishbelia, 2008). P.335-337

${ }^{54}$ Imam Al-Haramain Al-Juwayni, Kitabu L-Irshad Ila Qawati'i I-Adillah Fii Ushuli I-I'tiqad, ed. by Muhammad Yusuf Musa and Ali Abdu I-Mun'im Abdul-Hamid (Mesir: Matba'ah Al-Sa'adah, 1950). P.262

${ }^{55}$ Syeikh Ja'far Al-Subhani, Ar-Risalah Fii t-Tahsin Wa t-Taqbih, 1st edn (Qom: Mu'assasah Al-Imam As-Shadiq, 1999). 
Islam menganjurkan manusia untuk menggunakan akalnya dalam mengetahui kebaikan dan keburukan. Misalkan saja dalam ayat berikut:

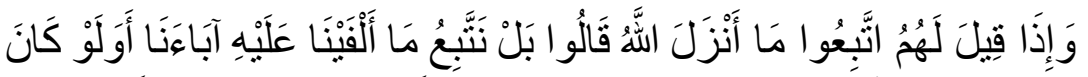

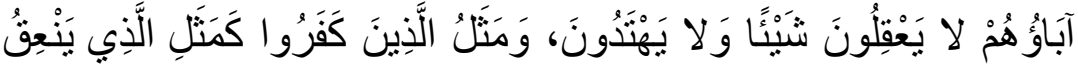

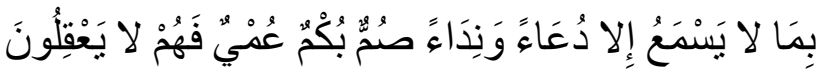

Dan apabila dikatakan kepada mereka: "Ikutilah apa yang telah diturunkan Allah," mereka menjawab: "tetapi Kami hanya mengikuti apa yang telah Kami dapati dari (perbuatan) nenek moyang kami". "(Apakah mereka akan mengikuti juga), walaupun nenek moyang mereka itu tidak mengetahui suatu apapun, dan tidak mendapat petunjuk?". Dan perumpamaan (orang-orang yang menyeru) orang-orang kafir adalah seperti penggembala yang memanggil binatang yang tidak mendengar selain panggilan dan seruan saja, mereka tuli, bisu dan buta, Maka (oleh sebab itu) mereka tidak mengerti. (Al-Baqarah 170-171)

Ayat ini menunjukkan bahwa orang yang kufur kepada Allah Swt tidaklah menggunakan akalnya, karena berdasarkan ayat ini jika dia menggunakan akalnya maka sudah tentu dia akan mengikuti Nabi Muhammad.

Maka menurut Ibnu Taymiyyah dan Ibnu Qayyim, mengetahui kebaikan dan keburukan dapat dilakukan melalui akal dan teks secara bersamaan. Karena akal adalah fitrah yang Allah tanamkan dalam diri manusia dan termasuk salah satu fakultas yang dengannya manusia dapat mencapai kebenaran, dan teks baik Al-Qur'an dan Al-Hadith juga tidak pernah melarang penggunaan akan maupun merendahkan peran akal dalam proses epistemologis 
manusia. ${ }^{56}$ Misalnya; manusia dengan akalnya dapat mengetahui bahwa mengesakan Allah adalah hal yang baik, sedangkan menyekutukannya adalah hal yang buruk. Kemudian Allah Swt dalam Al-Qur'an meyebutkan orang-orang yang menyekutukan-Nya adalah orang yang tidak berfikir dan tidak berakal, bahkan dengan permisalan yang lebih ekstrim, orang kafir dan musyrik adalah orang yang tuli, buta, dan bisu karena tidak menggunakan telinga, mata, dan lisannya untuk mengetahui kebenaran. Kemudian Allah memerintahkan kepada manusia untuk melihat, berjalan di muka bumi, mengambil pelajaran; semua itu menunjukkan bahwa akal adalah salah satu fakultas dalam menentukan kebaikan dan keburukan. ${ }^{57}$

Akal dalam mengetahui yang baik dan yang buruk akan mempertimbangkan apakah sesuatu itu disukai atau dibenci? Jika sesuatu itu disukai maka ia adalah baik namun jika dibenci adalah buruk. Jiwa manusia yang sehat akan selalu terdorong untuk menghasilkan sesuatu yang baik dan menolak berbagai bentuk keburukan baik secara syari'at ataupun tidak. Secara akal berbagai akhlaq semacam pengendalian diri, kesederhanaan, dermawan, suka menolong adalah kebaikan dan yang berlawanan darinya adalah keburukan. Fungsi dari syari'at disini bukan yang merubah nilai kebaikan dan keburukan yang ada dalam akal, namun ia berfungsi untuk meneguhkannya. Namun sebagaimana yang disebutkan oleh Ibnu I-Qayyim akal manusia terbatas dalam mengetahui semua

\footnotetext{
${ }^{56}$ Taqiyuddin Ahmad Ibnu Taimiyyah, Kitab Al-Raddu 'Ala I-Mantiqiyyin, ed. by Sayyid Sulayman Al-Nadawi, Abdu s-Samad Sharafu d-Din Al-Katibi, and Muhammad Talhah Bilal Minar, 1st edn (Beirut: Mu'assasah Al-Rayyan, 2005). P. 428

57 Abu Abdillah Muhammad bin Abi Bakr Bin Ayyub Ibnu I-Qayyim Al-Jawziyyah, Madariju S-Salikin Bayna Manazili lyyaka Na'budu Wa lyyaka Nasta'in, ed. by Muhammad Hamid Al-Fiqi (Beirut: Daaru I-Kutub al-'Arabi). P. 491
} 
maslahat-maslahat manusia yag lebih universal, ada saatnya ketika apa yang dikira manusia baik sesungguhnya kurang baik bahkan buruk, dan begitu pula sebaliknya. Allah mengingatkan:

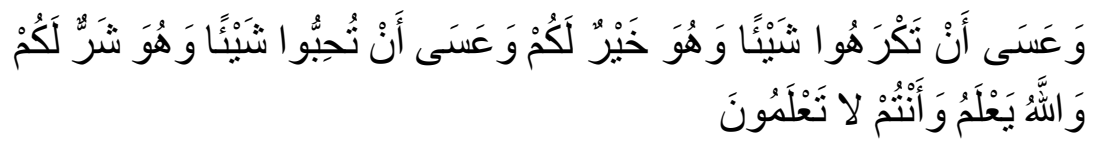

Boleh jadi kamu membenci sesuatu, padahal ia baik bagimu. Dan boleh jadi kamu menyukai sesuatu, padahal ia buruk bagimu; Allah mengetahui, sedang kamu tidak mengetahui. (Al-Baqarah:216)

Misalkan saja tentang Qishash mungkin secara tampak bagi sebagaian orang terlihat keji dan kejam. Karena pembunuh dibunuh, pencuri dipotong tangan, pezina dicambuk atau dirajam. Akal manusia, jika tidak dijelaskan lebih lanjut, tidak akan mengetahui bahwa sebenarnya dalam Qishash terdapat maslahat yang besar. Maka Allah dalam Al-Qur'an menjelaskan maslahat tersebut:

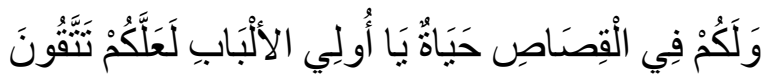

Dan dalam qishaash itu ada jaminan kelangsungan hidup bagimu, Hai orang-orang yang berakal, supaya kamu bertakwa. (Al-Baqarah:179)

Disinilah perlunya syari'at yang diturunkan Allah dalam Al-Qur'an dan Al-Hadith berfungsi sebagai pengingat dan petunjuk bagi manusia, agar ia dapat mengetahui kebaikan dan maslahat yang belum diketahui. ${ }^{58}$

58 Abu Abdillah Muhammad bin Abi Bakr Bin Ayyub Ibnu I-Qayyim Al-Jawziyyah, Miftahu D-Daru s-Sa'adah Wa Manshur Wilayatu I-'Ilmi Wa I-Iradah (Beirut: Daaru I-Kutub al-Ilmiyyah, 1998). P.374 


\section{AKHLAQ TENGAH}

Manusia yang berbahagia harus memiliki akhlak tengah atau "doctrine of the mean". Teori ini dapat ditemukan dalam pemikiran Socrates, Plato, dan Aristotle, bahwa segala sesuatu yang disebut baik selalu ada dipertengahan antara dua hal yang ekstrim. Sikap berani dipertengahan antara sikap pengecut dan tergesa-gesa, kemurahan hati adalah pertengahan antara boros dan kikir, rasa harga diri adalah pertengahan antara rendah diri dan sikap sombong, begitu pula seterusnya. Teori ini kemudian diikuti oleh para pemikir muslim, seperti Ibnu Miskawaih dan Imam Al-Ghazali.

Menurut para filosof peripatetik, jiwa manusia memiliki potensi-potensi (quwwah) ketika potensi itu berlebihan akan menciptakan kekacauan, dan ketika potensi itu kurang maka potensi tersebut tidak akan berfungsi dengan baik, atau dalam Bahasa Arabnya potensi itu berada pada keadaan yang adil; yakni memposisikan sesuatu pada letaknya, bukan dzalim; yakni tidak memposisikan sesuatu pada letaknya. Akhlaq tengah itulah yang disebut dengan al-fadha'il atau excellence atau keunggulan. Ibnu Miskawaih menyebutkan beberapa jenis keunggulan, diantaranya: Keberanian merupakan pertengahan antara sikap nekat dan kepengecutan, 'iffah atau pengendalian diri merupakan pertengahan antara ketamakan dan dingin hati, Hikmah merupakan pertengahan antara kebodohan dan kelancangan, Keadilan merupakan pertengahan antara teraniaya dan dianiaya. ${ }^{59}$

Misalkan potensi keberanian. Keberanian bersumber dari potensi amarah dalam diri manusia. Ketika meluap potensi amarah

59 Ibnu Miskawaih, Tahdhibu L-Akhlaq, ed. by Imad Al-Hilali (Beirut: Manshurat Jamal, 2011). p. 410 
tersebut, ia akan membuat darah mendidih seperti ketika seseorang membakar api di dalam gua, ini menyebabkan panas yang membara dan meluap-luap. Sehingga seseorang akan mudah sekali naik pitam dan suka melakukan sesuatu tanpa berfikir panjang (nekat). Namun jika potensi amarah dalam diri seseorang itu kurang atau bahkan tidak ada, akan menyebabkan dirinya menjadi seorang yang pengecut. Maka potensi amarah perlu diletakkan sesuai dengan porsinya dalam jiwa manusia, sehingga akan menghasilkan jiwa pemberani. ${ }^{60}$ Keberanian, menurut Plato, bukanlah seseorang yang maju sendirian di medan perang untuk melawan musuh, namun ia adalah orang yang mampu berfikir, menyusun strategi tentang bagaimana mengalahkan musuh. Dari dua contoh keadaan jiwa ini dapat disimpulkan bahwa akhlaq tengah adalah keadaan jiwa yang seharusnya dan sewajarnya, itulah akhlaq yang baik. Ketika akhlaq menjadi tidak seharusnya dan tidak sewajarnya maka itulah akhlaq yang buruk.

Keberanian, pengendalian diri, hikmah, dan Keadilan bagi Imam Al-Ghazali adalah pokok dari akhlaq. Keadilan bagi Imam Al-Ghazali adalah pengontrol dari keberanian, pengendalian diri, dan hikmah. Jika seseorang mampu bersikap adil di ketiga akhlaq tersebut manusia akan berada pada akhlaq pertengahan dan menghasilkan berbagai akhlaq yang merupakan cabang dari ketiganya. Cabang dari pokok-pokok akhlaq tersebut, antara lain: Keberanian akan menghasilkan watak; kehormatan, suka menolong, dermawan, menghancurkan dan mengontrol syahwat, menahan amarah, wibawa, saling mencintai dsbg. Pengendalian diri akan menghasilkan watak; kedermawanan, malu, sabar, toleransi, merasa cukup, menjaga diri dari yang haram dan yang melalaikan (wara'), kelembutan, suka membantu, luwes, dan tidak rakus. Hikmah akan menghasilkan watak; mampu mengatur dengan baik, fikiran yang

${ }^{60}$ Miskawaih, Tahdhibu L-Akhlaq. p. 411 
unggul, ide-ide yang tajam, perkiraan yang tepat, cerdas dalam melaksanakan berbagai pekerjaan dengan detail, dan mampu melenyapkan berbagai syahwat yang berbahaya. ${ }^{61}$

Ketika manusia mampu mencapai akhlaq pertengahan atau akhlaq yang baik, hal tersebut akan dapat memperbaiki keadaan tubuhnya dan membawanya pada kebaikan. Namun jika potensi tersebut tidak mampu berada pada porsi yang seharusnya, bisa jadi karena kekurangan atau berlebihan, maka akan mengakibatkan keburukan untuk tubuh dan jiwa. Ibnu Miskawaih menjelaskan dengan mengutip perkataan para ahli hikmah:

"Bahwa kenikmatan itu, jika ia benar, maka ia akan menggiring tubuh manusia dari kekurangan menuju kesempurnaan, dari kesakitan menuju kesehatan. Begitu juga kenikmatan dalam jiwa, ia benar jika membawa manusia dari kebodohan menuju pengetahuan, dari kehinaan menuju keunggulan, namun ada yang perlu diketahui oleh orang yang menuntut ilmu, bahwa kecenderungan manusia untuk kenikmatan inderawi sangatlah kuat, dan cinta kepadanya sangatlah mencemaskan. Dan kita tidak terpengaruh oleh hal tersebut karena watak awal kita kurang berpotensi untuk membentuk kecintaan terhadap hal-hal yang inderawi. Kenikmatan inderawi ini ketika berlebihan dalam mempengaruhi watak manusia, akan menciptakan keburukan. Manusia yang demikian akan mengatakan bahwa keburukan dan kehinaan adalah baik, dan tidak akan melihat kesalahan atau keburukan dalam hal itu sampai datangnya hikmah." ${ }^{62}$

Akhlaq pertengahan ini sebenarnya sudah dijelaskan oleh Rasulullah Saw dalam hadith, tentang bagaimana manusia memposisikan dirinya dalam kehidupan dunia dan akhirat, dan tentang bagaimana ia memenuhi kebutuhan jasmaninya dan jiwanya dengan adil:

\footnotetext{
${ }^{61}$ Al-Ghazali. P.936

${ }^{62}$ Miskawaih, Tahdhibu L-Akhlaq. p. 328
} 


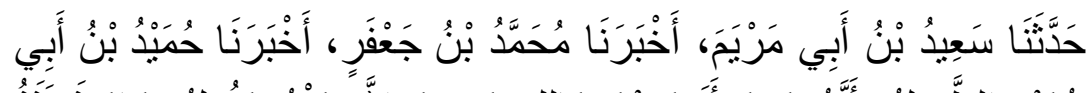

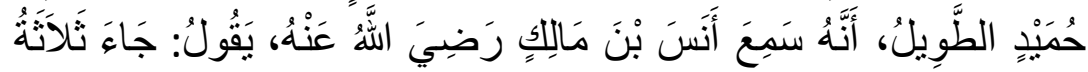

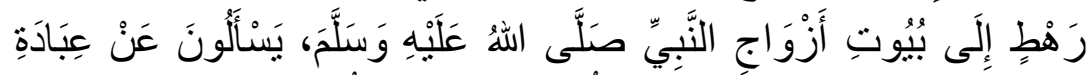

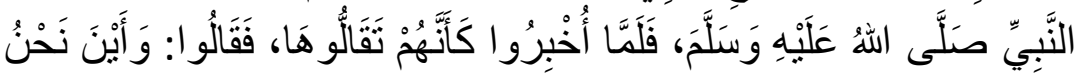

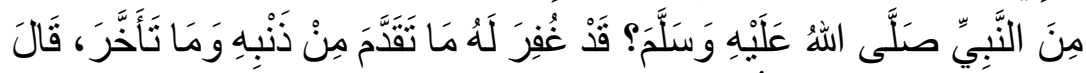

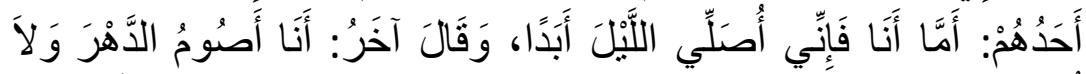

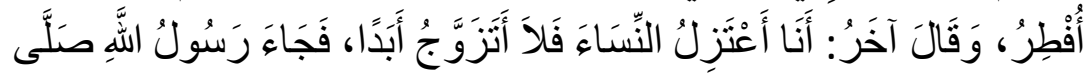

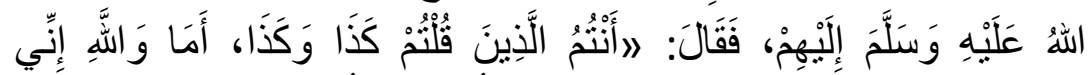

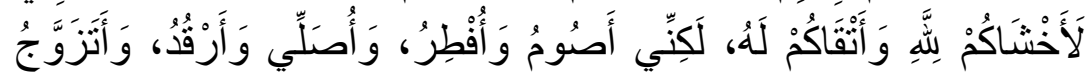

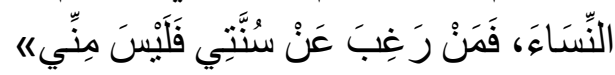

Anas bin Malik berkata: datang 3 kelompok ke rumah istri-istri Nabi Saw. mereka bertanya tentang Ibadah Nabi Saw. ketika diceritakan merekapun berkata: "kita ini tidak ada apa-apanya dibanding Nabi Saw? padahal dosa beliau sudah diampuni baik yang lalu ataupun yang akan datang." Berkatalah salah seorang diantara mereka: "aku shalat sepanjang malam", yang lain berkata: "aku berpuasa terus dan tidak makan." Berkata lainnya: "aku menjauhi wanita dan tidak akan menikah selamanya." Kemudian datanglah Rasulullah Saw kepada mereka, dan berkata: "kallian yang berkata begini... begini... begini... sungguh demi Allah, aku adalah orang yang paling takut kepada Allah dan yang paling bertakwa, namun aku berpuasa dan makan, aku shalat dan tidur, dan aku menikahi wanita, maka barang siapa yang benci atas sunnahku maka bukan bagian dariku., ${ }^{63}$

${ }^{63}$ Al-Bukhari. 7/2 
BAB II

\section{AL-ILAAHIYYAT \\ IMAN KEPADA ALLAH}

Pada bab ini akan dibahas tentang perkara-perkara ilahiyyat atau ketuhanan kemudian akan dijelaskan tentang bagaimana berakhlaq kepada Allah Saw.

\section{BUKTI-BUKTI BAHWA ALLAH ITU ADA DAN ESA}

Para ulama' Islam telah membuktikan Wujud Allah Swt, bahwa Allah itu ada dan esa. Ada beberapa argumentasi yang telah diutarakan oleh para ulama' tentang bukti-bukti adanya Allah Swt, di antara bukti itu adalah: 1. Bukti Anthropic (dalil I-'Inayah), 2. Bukti naluriah (dalil l-fitrah), 3. Bukti Penciptaan (dalil l-ikhtira'), 4. Bukti Empiris (dalilu t-tajribi).

\section{Bukti Anthropic (Dalil I-'Inayah/دليل العناية)}

Bukti Teleologis ini pertama kali diutarakan oleh Ibnu Rusyd, ${ }^{64}$ bahwa setiap apa yang ada di alam semesta ini diciptakan untuk manusia dan untuk membantu manusia di dalam hidupnya. Misalkan waktu malam, siang, matahari, bulan, bintang, bumi, tumbuh-tumbuhan, hewan-hewan dsb telah ada dan bertujuan untuk mendukung kehidupan manusia. Ibnu Rusyd mengutip sebuah ayat:

${ }^{64}$ Ibnu Rusyd, Al-Kasyf Fi Manahiji I-Adillah Fi Aqa'idi I-Millah, ed. by Muhammad Abid Al-Jabiri, 1st edn (Beirut: Markaz Daru I-Wihdah Al-Arabiyyah, 1998). P.118-119 


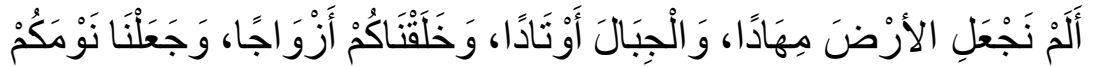

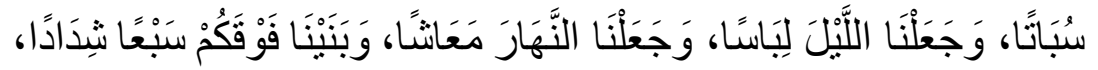

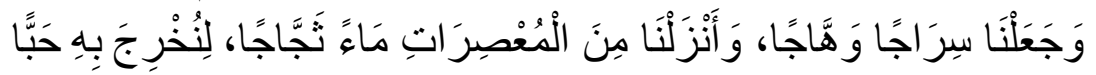

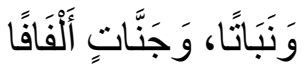

"Bukankah Kami telah menjadikan bumi itu sebagai hamparan?, dan gunung-gunung sebagai pasak?, dan Kami jadikan kamu berpasang-pasangan, dan Kami jadikan tidurmu untuk istirahat, dan Kami jadikan malam sebagai pakaian, dan Kami jadikan siang untuk mencari penghidupan, dan Kami bina di atas kamu tujuh buah (langit) yang kokoh, dan Kami jadikan pelita yang Amat terang (matahari), dan Kami turunkan dari awan air yang banyak tercurah, supaya Kami tumbuhkan dengan air itu biji-bijian dan tumbuh-tumbuhan, dan kebun-kebun yang lebat." (An-Naba': 6-16)

Ayat ini menunnjukkan bahwa seluruh penciptaan yang ada di langit dan di bumi adalah sesuai dengan kehidupan manusia dan bertujuan untuk kehidupan manusia. Ibnu Rusyd berargumentasi bahwa wujud alam memiliki satu tujuan yakni untuk manusia, menurutnya semua yang eksistensinya memiliki tujuan pasti diciptakan, dan semua yang diciptakan pasti memiliki pencipta.

\section{Bukti Naluriah (Dalil I-Fitrah/دليل الفطرة}

Bukti akan wujud Allah sudah ada dalam diri manusia; atau sudah merupakan fitrah atau naluri manusia untuk meyakini wujud Allah tanpa perlu melakukan penalaran logis. Imam Fakhr al-Din al-Razi dalam Mafatih al-Ghaib, ${ }^{65}$ menyebutkan bahwa Allah Swt telah menetapkan fitrah dalam diri manusia untuk meyakini bahwa Allah adalah Tuhan satu-satunya. Dalam Al-Quran surah Al-A'raf:172

${ }^{65}$ Fakhr al-Din Al-Razi, Tafsir Al-Fakhr Al-Razi Al-Mushtahir Bi-Tafsir Al-Kabir Mafatih Al-Ghaib, 1st edn (Beirut: Dar al-Fikr, 1981). 25/120-121 
Allah menjelaskan bahwa manusia sejak sebelum dilahirkan telah bersaksi bahwa Allah adalah Tuhannya:

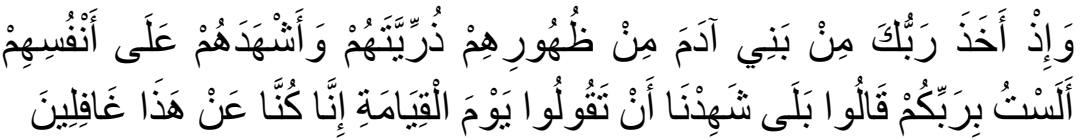

"Dan (ingatlah), ketika Tuhanmu mengeluarkan keturunan anak-anak Adam dari sulbi mereka dan Allah mengambil kesaksian terhadap jiwa mereka (seraya berfirman): "Bukankah aku ini Tuhanmu?" mereka menjawab: "Betul (Engkau Tuhan kami), Kami menjadi saksi". (kami lakukan yang demikian itu) agar di hari kiamat kamu tidak mengatakan: "Sesungguhnya Kami (Bani Adam) adalah orang-orang yang lengah terhadap ini (keesaan Tuhan)".

Dengan demikian keimanan akan keesaan Allah Swt adalah sesuatu yang sudah tertanam dalam diri manusia secara natural. Inilah yang kemudian mengispirasi Ibnu Tufail menulis sebuah karya yang berjudul Hayy bin Yaqdzan yang menceritakan seorang anak yang diasuh oleh rusa sejak kecilnya dan tidak pernah berkomunikasi dengan manusia, namun ketika ia dewasa dengan penalarannnya mampu meyakini bahwa ada satu kekuatan yang menciptakan alam semesta ini. ${ }^{66}$

Selanjutnya Allah Swt menyebutkan bahwa agar manusia selalu sesuai dengan fitrahnya maka ia harus mengikuti agama Islam. Dalam surah Ar-Rum:30 Allah Swt berfirman:

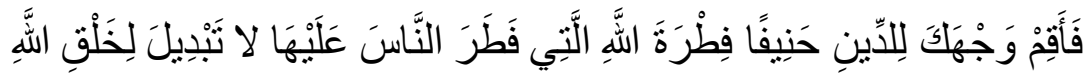

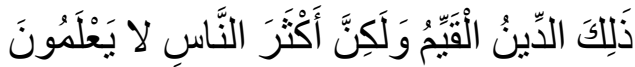

"Maka hadapkanlah wajahmu dengan lurus kepada agama Allah; (tetaplah atas) fitrah Allah yang telah menciptakan manusia menurut fitrah itu. tidak

${ }^{66}$ Ibnu Tufail, 'Hayy Bin Yaqdzan', in Hayy Bin Yaqdzan Li Ibni Sina Wa Ibni Tufail Wa Al-Suhrawardi, ed. by Ahmad Amin, Muhammad Azb, and Sulayman Al-Attar, 4th edn (Beirut: Daaru I-Ma'arif, 2007). P.41 
ada peubahan pada fitrah Allah. (Itulah) agama yang lurus; tetapi kebanyakan manusia tidak mengetahui."

Imam Ibnu Jarir Al-Tabari dan Ibnu Kathir ${ }^{67}$ menyebutkan bahwa maksud dari kata fitrah dalam ayat ini berarti Islam. Sebagaimana hadith Nabi yang berbunyi:

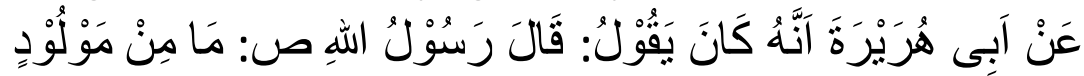

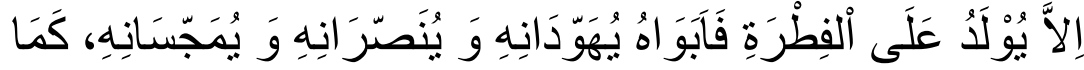

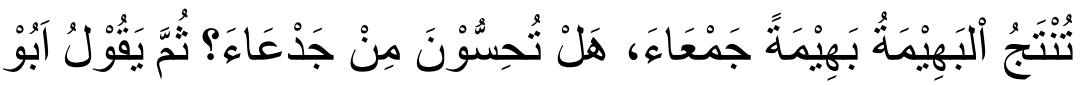

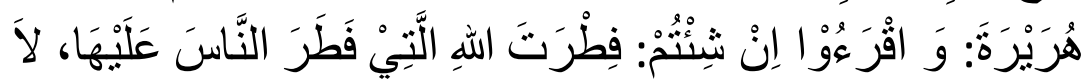
تَبْدِيْلَ لِخَلْتِ اللهِ.

Dari Abu Hurairah, bahwasanya dia berkata : Rasulullah SAW bersabda, "Tidaklah seorang anak yang dilahirkan melainkan terlahir atas fithrah, maka kedua orang tuanyalah yang menjadikannya Yahudi, Nashrani atau Majusi, sebagaimana binatang ternak dilahirkan (oleh induknya) dalam keadaan sempurna. Apakah kalian mengetahui ada yang telinganya terpotong ? Kemudian Abu Hurairah berkata, "Bacalah jika kalian mau : "Fitrah Allah yang telah menciptakan manusia menurut fithrah itu.Tidak ada perubahan pada fithrah Allah."68

Selanjutnya Ibn Al-'Athiyah dalam Tafsir al-Muharrar al-Wajiz, menyebutkan bahwa kalimat fitrah bisa ditafsirkan dengan kata asalnya yaitu al-khilqah akan tetapi melihat dari kata selanjutnya yaitu dzalika al-din al-qayyim dan kalimat laa tabdil li-khalqi Allah, maka ia berpendapat bahwa makna fitrah disini adalah ke-imanan

67 Abi Ja'far Muhammad Ibn Jarir Al-Thabari, Tafsir Al-Thabari Jami' Al-Bayan 'an Ta'wil Ay Al-Quran, 1st edn (Kairo: Dar al-Hijr, 2001) 18/493-497; 'Imad al-Din Abi al-Fida' 'Isma'il Ibn Al-Katsir, Tafsir Al-Quran Al-'Adzim, 1st edn (Kairo: Al-Faruq al-Hadits, 2000) 11/26.

${ }^{68}$ Muslim. 
dimana manusia telah melakukan perjanjian awal sebelum kelahirannya dimuka Bumi. ${ }^{69}$ Penafsiran ini juga diamini oleh $I b n$ al-Juziyi dalam al-Tashil li-'Ulum al-Tanzil bahwa al-khilqah atau naluri dasar manusia adalah mengikuti ajaran agama Islam, hal ini hanya akan terjadi ketika ia masih mengikuti akal sehatnya. Akan tetapi ketika mereka menutupi (kafara) dengan apa yang diturunkan oleh Allah maka mereka menjauh dari asal fitrah-nya. ${ }^{70}$

\section{Bukti Penciptaan (Dalil l-Ikhtira'/دليل الاختر اعثر)}

Pada tulisan kali ini akan diulas argumentasi penciptaan yang diutarakan oleh Imam Abu Hasan Al-Ash'ari (330 H) dalam kitab Al-Luma'. ${ }^{71}$

Imam Al-Ash'ari menjelaskan bukti bahwa setiap ciptaan pasti ada penciptanya (al-khaliq). la berkata bahwa manusia pada mulanya adalah air mani, lalu menjadi segumpal daging, lalu terbentuklah daging, darah dan tulang. Kemudian manusia ketika tubuhnya telah sempurna, kemudian ia berakal, mampu mendengar dan melihat, hal ini tidak mungkin terjadi dengan sendirinya.

Kemudian ketika manusia masih baru keluar dari rahim sang ibu, ia masihlah lemah, tidak bisa melihat dan mendengar (buta, tuli, dan bisu), tidaklah mungkin yang lemah mampu menciptakan pendengaran dan pengelihatan bagi dirinya sendiri. Maka pasti ada yang menciptakan pendengaran dan pengelihatan itu.

${ }^{69}$ Abu Muhammad 'Abdu al-Haq Ibn al-Ghalib Ibn 'Athiyah, Al-Muharrar Al-Wajiz Fi Tafsir Al-Kitab Al-'Aziz, 1st edn (Beirut: Daaru I-Kutub al-Ilmiyyah, 2001).4/337.

${ }^{70}$ al-Qasim Muhammad Ibn Ibn Juziyi, Al-Tashil Li-'Ulum Al-Tanzil, 1st edn (Beirut: Daaru I-Kutub al-Ilmiyyah, 1998) 2/168.

${ }^{71}$ Abu Hasan Al-Ash'ari, Al-Luma' Fi Raddi 'Ala Ahli z-Zayghi Wa I-Bida', ed. by Hamudah Gharabah (Mesir: Maktabah Mishr, Shirkah Sahimah Misriyyah, 1955). P.6-9 
Pada mulanya manusia adalah bayi, remaja, beranjak dewasa, kemudian tua dan mati. Tidaklah mungkin bagi manusia untuk memilih bagi dirinya sendiri untuk remaja selamanya. Maka pasti ada yang memindahkannya dari keadaan satu ke-keadaan yang lainnya.

Hal ini seumpama kapas, ia tidak mungkin dapat berupa kain tenun dengan sendirinya, kecuali ada yang membuatnya atau menenunnya. Oleh karenanya, setiap ciptaan pasti ada yang menciptakannya yakni Allah SWT. Bukti akan adanya Allah sesungguhnya ada dalam ciptaannya termasuk diri manusia itu sendiri (QS. 56 : 58 - 59, QS. $51: 21$ ).

Imam Al-Ash'ari juga menjelaskan bahwa Allah itu pasti esa atau satu, karena jika Allah itu ada dua atau lebih berarti ada dua kehendak, jika satunya hendak menciptakan dan satunya hendak menghancurkan, tidak mungkin suatu benda itu diciptakan dan dihancurkan dalam waktu yang bersamaan. Maka harus ada satu kehendak yang dapat terealisasikan, Allah berfirman:

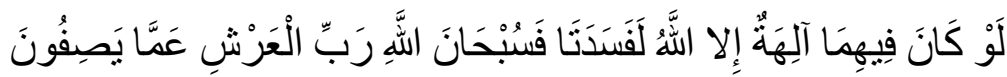

"Sekiranya ada di langit dan di bumi tuhan-tuhan selain Allah, tentulah keduanya itu telah rusak binasa. Maka Maha suci Allah yang mempunyai 'Arsy daripada apa yang mereka sifatkan." (Al-Anbiya': 22)

\section{Bukti Empiris (Dalilu t-Tajribi/ دليل التجريبي)}

Kaum atheis sering menjadikan bukti-bukti empiris, atau bukti yang didasarkan pada pengalaman panca indera, sebagai alat untuk menolak wujud Allah SWT. Di zaman modern ini, telah ada beberapa 'ulama' dan sarjana muslim yang mencoba membuktikan keberadaan Allah berdasarkan fakta-fakta empiris yang sudah 
diafirmasi oleh sains modern. Salah satunya adalah Maulana Wahidu d-Din Khan, seorang 'ulama' Pakistan menulis karyanya yang judul "Arabnya "Al-Islam Yatahadda" judul Inggrisnya, "God Arises" dalam bahasa Indonesianya "Islam menjawab tantangan Zaman."72

Khan mengungkapkan berbagai macam bukti akan wujud Allah berdasarkan pada fakta empiris. Diantaranya ia menggunakan fakta "hukum kedua tentang dinamika panas" (second law of thermo dynamics), hukum ini menjelaskan tentang "kaedah perubahan" (law of entropy) yang terjadi pada energy panas, bahwa energy panas selalu berpindah dari keadaan "adanya panas" menuju ke-"tiadanya panas". Dan kejadian sebaliknya tidak dimungkinkan, seumpamanya : besi yang dingin dengan sendirinya menjadi panas tanpa adanya pengaruh dari luar, ini adalah hal yang mustahil. Jadi, energy panas selalu diawali dengan sebab tertentu dan ia memiliki akhiran.

Perlu diketahui bahwa energy panas merupakan energy terpenting bagi kehidupan makhluq hidup dan kehidupan benda-benda angkasa. Seperti Matahari dan bintang-bintang lainnya, dapat berfungsi karena adanya energy panas ini. Seandainya panas itu hilang maka Matahari akan mati dan kehidupan yang ada di Bumi khususnya pasti juga akan sirna.

Berdasarkan fakta ini maka bisa dilihat bahwa 'alam semesta pastilah memiliki permulaan, karena jikalau alam ini tidak berkemulaan (azali), maka energy panas yang dimilikinya barang tentu sudah lama habis. Dan ia memiliki keberakhiran karena "panas" selalu menuju pada ke-"tiadanya panas". Selain itu 'alam tidak mungkin memiliki panas dengan sendirinya, karena energy panas hanya dapat terjadi karena pengaruh dari luar, dan perpindahan dari ke-"tiadanya panas" menjadi "adanya panas"

\footnotetext{
${ }^{72}$ Wahidu d-Din Khan, Al-Islam Yatahadda, ed. by Zafarul Islam Khan, 4th edn (New Delhi: Goodword Books, 2005). P. 54-56.
} 
adalah hal yang mustahil. Dengan demikian sudah tentu ada yang menciptakan dan mengatur 'alam semesta ini.

\section{TAUHID DAN ASPEK-ASPEKNYA}

Aqidah Islam yang dibawa oleh Nabi Muhammad SAW berisikan Tauhid, ${ }^{73}$ yakni mengesakan Allah Swt sebagai dhat yang esa tiada sekutu bagi-Nya, lalah satu-satunya yang mencipta, mengatur dan memiliki seluruh alam semesta, lalah yang berhak dan harus disembah, la tersucikan dari segala kekurangan dan bersifat dengan segala kesempurnaan. ${ }^{74}$

Tauhid merupakan ajaran agama yang dibawa oleh para nabi sebelum Muhammad. Menurut Imam As-Syaukani bahwa tujuan dari diutusnya rasul dan nabi serta diturunkannya kitab-kitab adalah untuk membenarkan Tauhid, bahkan ia memberikan beberapa contoh dalam kitab sebelum Al-Qur'an, seperti Taurat, Zabur dan Injil, kalimat-kalimat yang menunjukkan pada keesaan Allah. ${ }^{75}$ Mengenai hal ini Allah Swt berfirman melalui lisan Yusuf As :

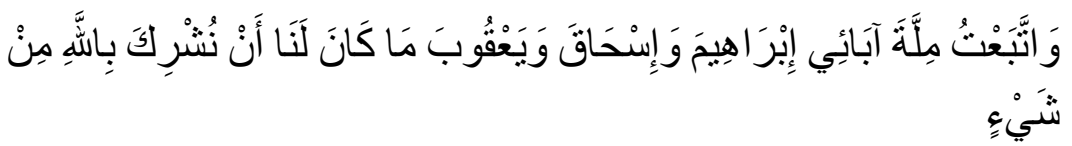

“Dan aku pengikut agama bapak-bapakku Yaitu Ibrahim, Ishak dan Ya'qub.

Tiadalah patut bagi Kami (para Nabi) mempersekutukan sesuatu apapun dengan Allah." (Yusuf : 38)

\footnotetext{
${ }^{73}$ Sa'id Hawa, Al-Asas Fi s-Sunnah Wa Fiqhuha, 2nd edn (Kairo: Daaru s-Salam, 1992). P.5

${ }^{74}$ Muhammad Yasri, 'Ilmu t-Tauhid 'Inda Ahl s-Sunnah Wa l-Jama'Ah, 1st edn (سلسلة المدخل المفيد إلى علم التوحيد 1, Islamkotob.com>. p. 75

${ }^{75}$ Muhammad Bin Ali As-Syaukani, Irshadu L-Tsiqah Ila Ittifaqi s-Shara'i' 'Ala I-Tawhid Wa I-Ma'Ad Wa I- Nubuwat, 1st edn (Beirut: Daaru I-Kutub al-Ilmiyyah, 1984). P.5-9
} 
Dengan demikian, Aqidah Islam adalah Aqidah Tauhid yang merupakan inti dari ajaran seluruh para nabi dan Rasul.

Tauhid dibagi menjadi dua yakni Tauhid I-Ma'rifah wa l-Ithbat dan Tauhid I-Iradah wa t-Thalab, atau dibagi menjadi tiga, yakni: Tauhid Rububiyyah, Uluhiyyah, Asma' wa s-Shifat.

Tauhid I-Ma'rifah wa l-Ithbat

Tauhidu I-Ma'rifah wa l-Itsbat (توحيد المعرفة والإثبات) atau Tauhid Pengetahuan dan Afirmasi, Tauhid ini dibagi kedalam dua bagian :

1. Tauhidu r-Rububiyyah (توحيد الربوبية), yakni mengesakan Allah sebagai satu-satunya yang mencipta, mengatur dan memiliki Alam semesta. Tauhid ini berkenaan dengan afirmasi wujud Allah sebagai pencipta alam semesta. ${ }^{76}$ Dalil Al-Qur'an yang menerangkan hal ini banyak sekali diantaranya:

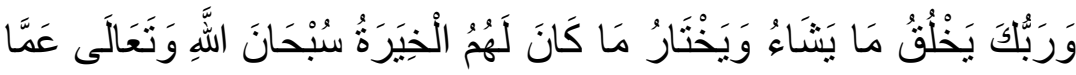
بُشثْرِكُونَ

"Dan Tuhanmu menciptakan apa yang Dia kehendaki dan memilihnya. Sekali-kali tidak ada pilihan bagi mereka. Maha suci Allah dan maha tinggi dari apa yang mereka persekutukan (dengan Dia)." (Al-Qashash : 68)

2. Tauhidu I-Asma' wa s-Shifat (توحيد الأسماء والصفات), yakni bahwa Allah Swt satu-satunya pemilik nama dan sifat yang menunjukkan kesempurnaan, keagungan dan kebesaran-Nya.

76 'Abdu Al-Razzaq bin Abdu Al-Muhsin, No Title, Al-Qaul Al-Sadid Fi Ar-Raddi 'Ala Man Ankara Taqsima t-Tauhid, Cet: 1 (Riyad: Dar Ibnu I-Qayyim, 2003). P.16-19 
Sifat adalah yang menunjukkan pada keadaan suatu objek. ${ }^{77}$ Sedangkan Nama atau asma' adalah sebutan untuk suatu objek. ${ }^{78}$ Untuk mempermudah pemahaman, ambillah contoh Sahabat Rasullullah Khalid bin Walid Ra yang terkenal memiliki sifat berani di medan perang, sehingga para Sahabat Nabi yang lain menjulukinya dengan nama Sayfullah Al-Maslul atau Pedang Allah yang Terhunus. Hal ini juga sama dengan Allah yang memiliki sifat rahmat maka dijuluki la dengan Al-Rahman Al-Rahim, la yang memiliki sifat kuasa (qudrah) maka dijuluki Yang Maha Berkuasa (Al-Qadir) dsbg.

Seorang Mu'min harus mengakui nama dan sifat Allah dan tidak boleh mendustakannya, mengenai hal ini Allah Swt berfirman :

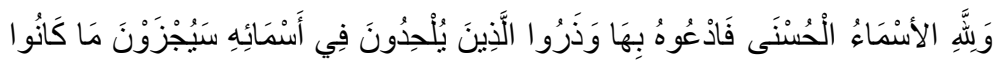
لَبْعَلُونَن

"Hanya milik Allah asmaa-ul husna. Maka bermohonlah kepada-Nya dengan menyebut asmaa-ul husna itu dan tinggalkanlah orang-orang yang menyimpang dari kebenaran dalam (menyebut) nama-nama-Nya. Nanti mereka akan mendapat Balasan terhadap apa yang telah mereka kerjakan." (Al-A'raf : 180)

Sifat dan nama Allah harus sesuai dengan apa yang la sifati atas dirinya sendiri dalam Al-Qur'an dan Sunnah Rasulullah, serta tidak boleh diingkari. ${ }^{79}$ Semisal: Al-Rahman Al-Rahim yakni yang maha pengasih, lagi penyayang, Al-Qadir atau yang berkuasa, Al-Murid atau yang berkehendak, dsbg.

77 Ali Bin Muhammad Al-Jurjani, Al-Ta'rifat, 1st edn (Beirut: Maktabah Lubnan, 1985). P.114

${ }^{78}$ Al-Jurjani. P.23

${ }^{79}$ Sa'id bin 'Ali bin Wahf Al-Qahtani, Nur T-Tauhid Wa Dhulmatu s-Shirk Fi Dau'i I-Kitab Wa s-Sunnah, 3rd edn (Riyad: Maktabah Malik Fahd, 2000). P.16-17 


\section{TAUHID L-IRADAH WA T-THALAB}

Tauhidu I-Iradah wa I-Thalab (توحيد الإرادة والطلب)/ terj: "mengesakan Allah dengan kehendak dan meminta" atau Tauhidu I-Uluhiyyah (توحيد الألوهية). Tauhid ini merupakan tujuan dari diutusnya para rasul dan nabi, bahwa manusia hanya boleh beribadah, mengharap, takut, tawakkal dan taqwa hanya untuk Allah semata. ${ }^{80}$ Dahulu orang musyrik juga meyakini bahwa Allah sebagai pencipta dan pengatur alam semesta. Namun dalam urusan peribadatan orang musyrik menyekutukan Allah dengan sesembahan yang lainnya. ${ }^{81} \mathrm{Al}$-Qur'an mengisyaratkan:

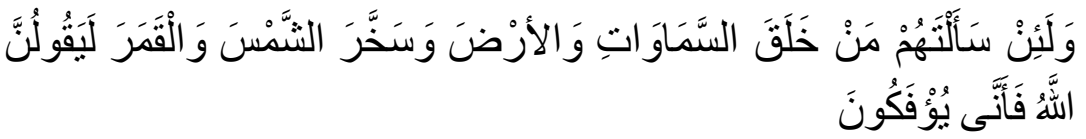

"Dan Sesungguhnya jika kamu tanyakan kepada mereka: "Siapakah yang menjadikan langit dan bumi dan menundukkan matahari dan bulan?" tentu mereka akan menjawab: "Allah", Maka betapakah mereka (dapat) dipalingkan (dari jalan yang benar)." (Al-Ankabut: 61)

Orang yang tahu bahwa Allah adalah Tuhan, namun tidak menujukan peribadatan kepada-Nya belum disebut Muslim. Seorang Muslim dalam bertauhid harus meyakini ketuhanan Allah beserta seluruh sifat dan nama-nama-Nya, dan hanya melakukan peribadatan untuk-Nya. ${ }^{82}$ Allah berfirman:

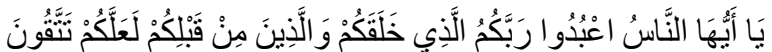

\footnotetext{
${ }^{80}$ Taqiyuddin Ahmad Ibnu Taimiyyah, Majmu' Fatawa (Kairo: Daru I-Wafa', 2005). P.73

${ }^{81}$ Taqiyuddin Ahmad bin Ali Al-Maqrizi, Tajridu T-Tauhid Al-Mufid (Kairo: Markaz I-Kitab li n-Nashr). P.17-20

${ }^{82}$ Abu Bakar Muhammad Zakariya, As-Shirk Fi I-Qadim Wa I-Hadith Juz : 1, 1st edn ((Riyadh: Maktabatu r-Rushdi, 2000). P.66-76
} 
"Hai manusia, sembahlah Tuhanmu yang telah menciptakanmu dan orang-orang yang sebelummu, agar kamu bertakwa". (Al-Baqarah: 21)

Merupakan fitrah bagi manusia untuk menyembah hanya kepada Allah, karena Allah-lah satu-satunya yang menciptakan manusia. Sedangkan penyembahan kepada selain Allah adalah suatu kedzaliman, karena tuhan-tuhan itu tidak dapat memberikan faedah ataupun madharat :

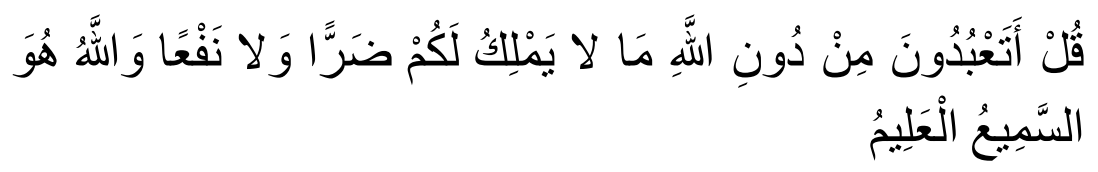

Katakanlah: "Mengapa kamu menyembah selain daripada Allah, sesuatu yang tidak dapat memberi mudharat kepadamu dan tidak (pula) memberi manfaat?" dan Allah-lah yang Maha mendengar lagi Maha mengetahui." (Al-Ma'idah: 76)

\section{SIFAT 20}

Para Ulama' dari Madzab 'Ash'ariyyah, sebagaimana yang disusun oleh Imam Al-Sanusi, ${ }^{83}$ menetapkan 20 sifat Allah yang wajib, maksudnya bukan berarti Allah hanya memiliki 20 sifat ini saja, namun seorang muslim tidak boleh menolak atau tidak mengimani bahwa ke- 20 sifat ini. Ke-20 sifat ini antara lain:

Sifat Nafsiyyah (صفة نفسية)

1. Wujud (الوُجُوُْْونُ : bahwa Allah itu pasti ada dan mustahil la tidak ada (عَدَمُّم), Sifat Wujud ini disebut juga dengan sifat

${ }^{83}$ Abu Abdullah Muhammad Bin Yusuf Al-Sanusi, Sharhu L-Muqaddimat, ed. by Nazar Hamadi, 1st edn (Riyad: Maktabah I-Ma'arif, 2009). 
nafsiyyah yaitu sifat yang menunjukkan bahwa diri Allah itu ada.

\section{Sifat Salbiyyah (صفة سلبية)}

Disebut sifat salbiyyah atau sifat yang meniadakan sesuatu, maksudnya adalah meniadakan bagi Allah SWT; awal, akhir, yang serupa, tempat bergantung, dan sekutu.

2. Qidam (القِدَمُم): bahwa tidak ada sesuatu apapun yang mendahului Allah, dan Allah tidak memiliki permulaan, la ada pertama kali (الأَََّْن) sebelum makhluq.

3. Baqa' (البقاء): atau kekal bahwa Allah itu tidak memiliki akhir atau la tidak binasa.

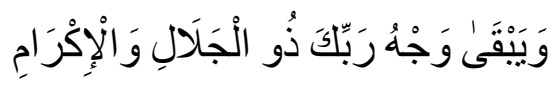

"Dan yang kekal hanyalah wajah Tuhanmu yang memiliki keagungan dan kemuliaan". (Ar-Rahman: 27)

Karena Allah memiliki sifat Qidam dan Baqa' maka diberi nama "Al-Awwal wa l-Akhir"

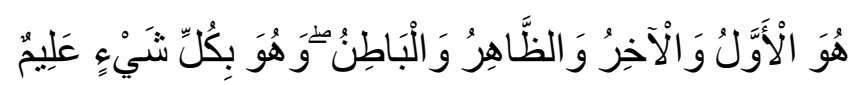

"Dialah Yang Awal, Yang Akhir, Yang Nampak, dan Yang Tersembunyi, dan la mengetahui segala sesuatu". (Al-Hadid:3)

Tafsiran ayat ini adalah bahwa Allah itu sebagai yang awal karena tidak ada sesuatu sebelum-Nya, dan sebagai yang akhir karena tidak ada sesuatu setelah-Nya, pengetahuan-Nya meliputi segala yang nampak dan yang tersembunyi. 
4. Mukhalafatu li Hawadithi (مخالفة لحو اديبث): atau "berbeda dengan makhluk-Nya" maksudnya tidak ada satupun yang dapat menyerupai Allah SWT.

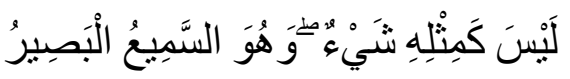

"Tidak ada yang menyerupai-Nya (Allah) dan Dialah yang maha mendengar dan maha melihat." (As-Syura: 11)

5. Qiyamuhu Binafsihi (قبامه بنفسه): atau "Allah ada dengan diri-Nya sendiri" tidak membutuhkan apapun, tidak disebabkan oleh apapun.

$$
\text { فَإنَّ اللَّهَ غَنِيٌْ عَنِ الْعَالَمِينَ }
$$

"Allah maha kaya dan tidak membutuhkan sesuatu dari alam semesta." (Ali Imron: 97)

$$
\text { اللَُّع الصَّمَدُ }
$$

"Allah itu Samad" (Samad: yang tidak membutuhkan sesuatu, yang mencukupi segala kebutuhan, yang memiliki segala kemuliaan) (Al-Ikhlas: 2).

6. Wahdaniyyah (و حدانبة): atau Allah itu esa, satu tidak ada sekutu baginya.

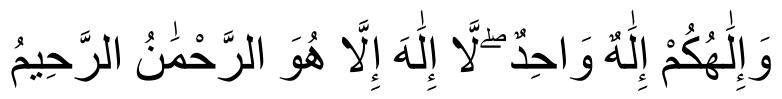

"Dan Tuhanmu adalah Tuhan yang Esa, tiada Tuhan kecuali la yang Maha Pengasih lagi Maha Penyayang" (Al-Baqarah 163)

$$
\text { فُلْ هُوَ اللَُّ أَحَدُ }
$$

“Katakanlah Dialah Allah yang Esa." (Al-Ikhlas:1) 


\section{Sifatu L-Ma'ani (صفة المعاني)}

Yakni sifat yang digambarkan seperti sifat manusia dan makhluk. Walaupun ada persamaan dalam penggambaran sifat Allah dengan makhluk-Nya, namun tidak bisa disamakan sifat Allah dengan makhluk, dan juga sifat ini tidak boleh dihilangkan dari Allah. Sifat-sifat itu antara lain:

7. Qudrah (قدرة): Allah memiliki sifat kuasa

8. Iradah (إد ادة): Allah memiliki sifat kehendak

9. IImu (علم): Allah memiliki sifat IImu

10. Hayaah (حباة): Allah memiliki sifat hidup

11. Sama' (سمع): Allah memiliki pendengaran

12. Basar (بصر): Allah memiliki Pengelihatan

13. Kalam (كلاد): Allah memiliki sifat bicara atau berkata Karena Allah memiliki sifat I-ma'ani, maka melazimkan adanya SIFAT MA'NAWIYYAH (صفة معنوية), antara lain:

14. Qadir (قادر): Yang Berkuasa; karena Allah memiliki kekuasaan, maka Allah pun berkuasa dengan kekuasaannya.

15. Murid (مر يد): Yang berkehendak; karena Allah memiliki kehendak, maka Allah pun berkehendak dengan kehendaknya. 
16. Aliim (عالم): Yang mengetahui; karena Allah memiliki IImu, maka dengan Ilmu itu Allah mengetahui yang segala sesuatu.

17. Hayy (حِي): Yang hidup; karena Allah itu memiliki sifat hidup, maka Allah pun Hidup.

18. Saami' (سمبع): Yang mendengar; karena Allah memiliki pendengaran, maka Allah mendengarkan dan tidak tuli.

19. Baasir (بصير): Yang melihat; karena Allah memiliki pengelihatan, maka Allah melihat dan tidak buta.

20. Mutakallim (متكلّم): Yang berbicara; karena Allah memiliki sifat bicara, maka Allah pun berbicara dan tidak bisu.

\section{Perhatian!}

Bukan berarti dengan menetapkan sifat-sifat ini lantas dikatakan bahwa sifat Allah itu hanya 20, namun sifat-sifat ini adalah sifat yang tidak boleh ditiadakan dari Allah. Para Ulama' menetapkan sifat-sifat ini karena telah dinafikan oleh kelompok-kelompok sesat seperti: Jahmiyyah dan Mu'tazilah. Maka peletakan sifat 20 ini sebagai bentuk penegasan bahwa Allah bersifat dengan sifat diatas sebagaimana yang telah ditetapkan dalam Al-Qur'an dan Hadith.

Tidak boleh menyamakan sifat-sifat diatas dengan sifat manusia, misalkan; "Allah berbicara seperti bicaranya Ahmad." Namun harus disifati bahwa Allah berkuasa, berkehendak, mengetahui, hidup, mendengar, melihat, berbicara bukan seperti makhluq-Nya, tidak perlu dipertanyakan (دُونَ تَكْنْيْنِ dan tidak pula ditiadakan atau diingkari (وَ لَا تَعْطِنْلِ), cukup diimani saja, karena manusia tidak akan pernah bisa mencapai pengetahuan itu. 


\section{ASMA'U L-HUSNA}

Allah SWT memiliki Asma'u I-Husna atau nama-nama yang baik sebagaimana la telah menamai diri-Nya sendiri. Dalam hadith yang diriwayatkan oleh Ibrahim bin Ya'qub dalam Sunan Al-Tirmidzi, ada detail dari nama-nama tersebut walaupun hadithnya tidak shahih, nama-nama itulah yang kemudian terkenal hingga sekarang:

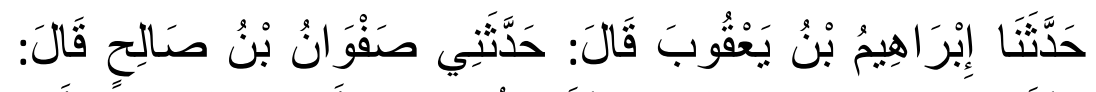

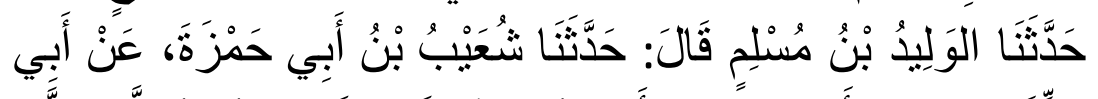

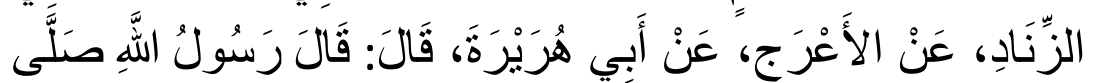

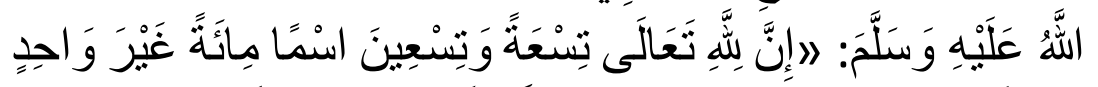

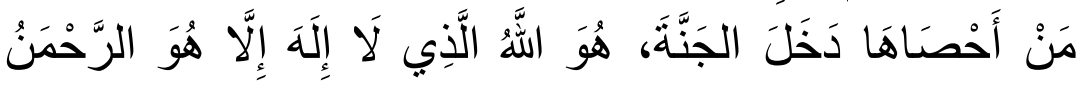

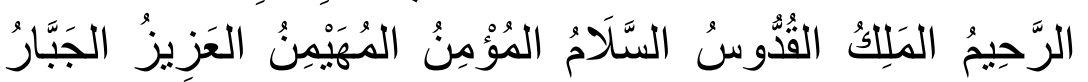

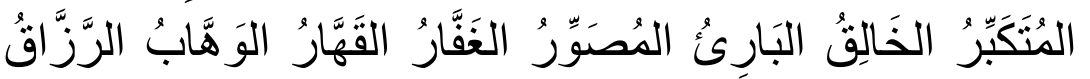

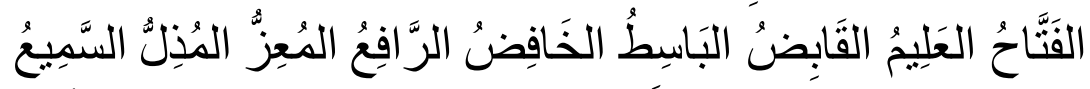

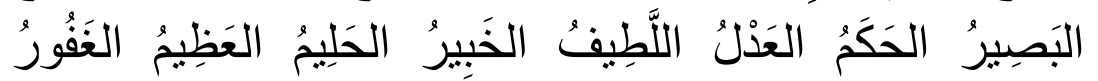

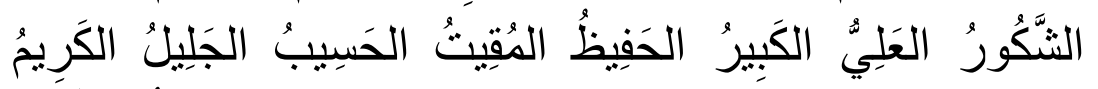

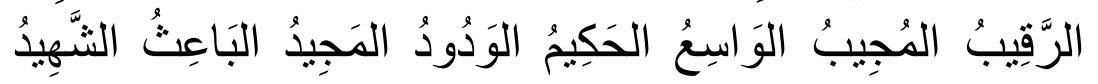

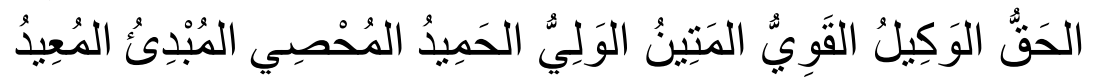

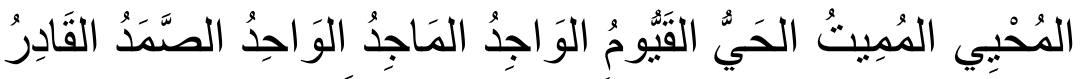

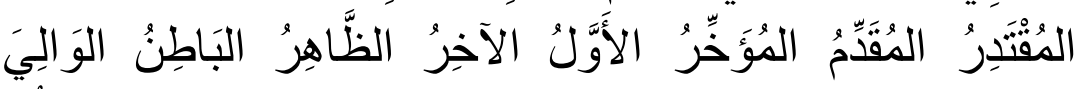

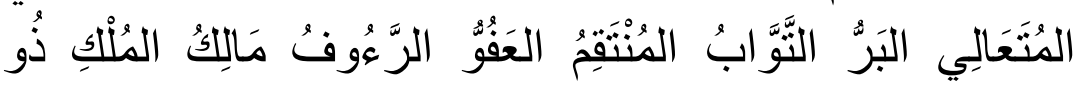

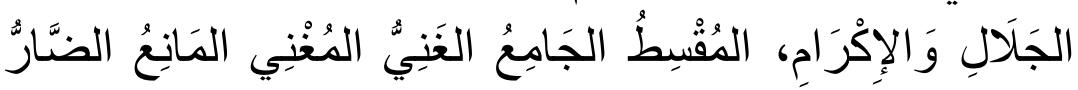




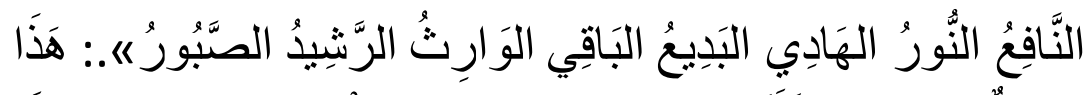

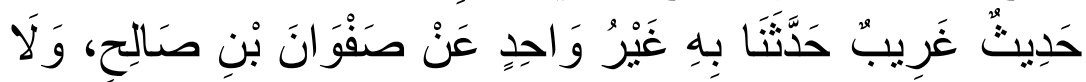

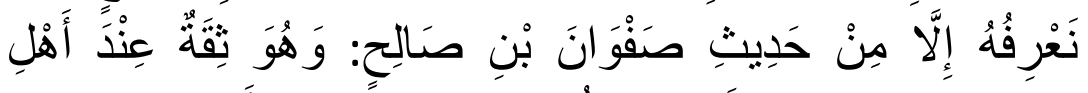

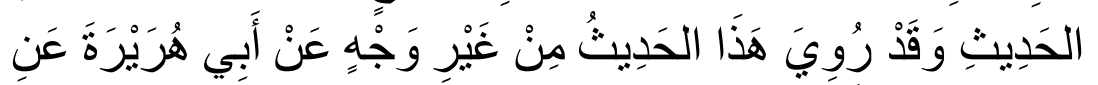

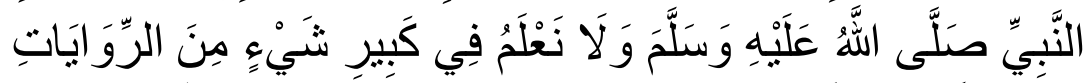

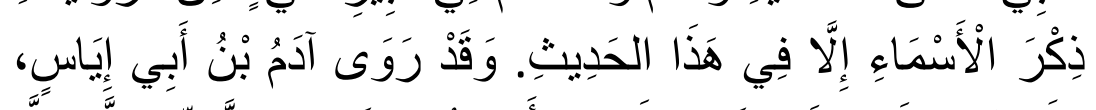

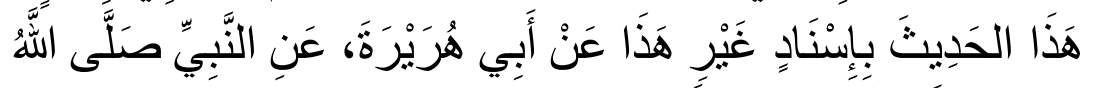

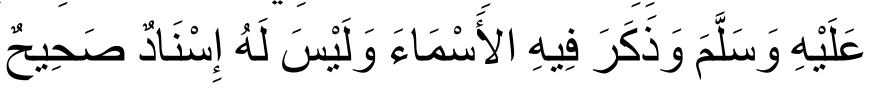

Terjemahannya: Telah berkata: Ibrahim bin Ya'qub Al Jurajani. Telah berkata: Shafwan bin Shalih. Telah berkata: Al Walid bin Muslim. Telah berkata: Syu'aib bin Abu Hamzah. Dari Abu Az Zinad. Dari Al A'raj. Dari Abu Hurairah, beliau berkata; Rasulullah allugate pernah bersabda: "Sesungguhnya Allah ta'ala memiliki sembilan puluh sembilan nama, seratus kurang satu. Barang siapa yang menghitung dan menghafalnya akan masuk Surga. Yaitu; Allah yang tidak ada tuhan selain Dia, Dialah Ar Rahman, Ar Rahim, Al Malik, Al Quddus, As Salamu, Al Mukmin, Al Muhaiminu, Al 'Aziz, Al Jabbar, Al Mutakabbir, Al Khaliq, Al Bari'u, Al Mushawwiru, Al Ghaffaru, Al Qahhar, Al Wahhab, Ar Razzaq, Al Fattah, Al 'Alim, Al Qabidh, Al Basith, Al Khafidh, Al Mu'iz, Al Mudzill, As Sami', Al Bashir, Al Hakam, Al 'Adlu, Al Lathif, Al Khabir, Al Halim, Al 'Azhim, Al Qhafur, Asy Syakur, Al 'Aliyyu, Al Kabir, Al Hafizh, Al Muqitu, Al Hasib, Al Jalil, Al Karim, Ar Raqib, Al Mujib, Al Wasi', Al Hakim, Al Wadud, Al Majid, Al Ba'its, Asy Syahid, Al Haqqu, Al Wakil, Al Qawiyyu, Al Matin, Al Waliyyu, Al Hamid, Al Muhshi, Al Mubdi', Al Mu'id, Al Muhyi, Al Mumit, Al Hayyu, Al Qayyum, Al Wajid, Al Majid, Al Wahid, Ash Shamad, Al Qadir, Al Muqtadir, Al Muqaddim, Al Muakhkhir, Al Awwalu, Al Akhir, Azh Zhahir, Al Bathin, Al Wali, Al Muta' Ali, Al 
Barru, At Tawwab, Al Muntaqimu, Al Afuwwu, Ar Rauf, Malikul Mulk, Dzul Jalal wal Ikram, Al Muqsith, Al Jami', Al Ghani, Al Mani', Adh Dharr, An Nafi', Al Hadi, Al Badi', Al Baqi, Al Warits, Ar Rasyid, Ash Shabur."Abu Isa berkata; Hadits ini adalah Hadits gharib. Telah menceritakan kepada kami dengan hadits tersebut lebih dari satu orang dari Shafwan bin Shalih dan kami tidak mengetahuinya kecauli dari hadits Shafwan bin Shalih, dan ia adalah orang yang tsiqah menurut ahli hadits. Dan hadits ini telah diriwayatkan lebih dari satu jalur dari Abu Hurairah dari Nabi aلle dan kami tidak mengetahui kebanyakan riwayat-riwayat tersebut memiliki sanad yang shahih yang menyebutkan nama-nama kecuali hadits ini. Dan Adam bin Abu lyas telah meriwayatkan hadits ini dengan sanad selain ini dari Abu Hurairah dari Nabi aلd aلd dan padanya ia menyebutkan nama-nama tersebut, dan tidak memiliki sanad yang shahih. ${ }^{84}$

\section{SYIRIK DAN HAL-HAL YANG DAPAT MERUSAK AQIDAH}

Syirik merupakan lawan kata dari Tauhid. Secara bahasa "syirik" berarti persekutuan, pertemanan dan percampuran. Secara istilah syirik memiliki berarti: menyekutukan Allah, melakukan peribadatan kepada selain Allah, menyamakan antara Allah dengan makhluq-Nya atau mensifati makhluq dengan sifat Allah. ${ }^{85}$ Syirik adalah dosa yang tidak akan pernah diampuni oleh Allah Swt. la berfirman :

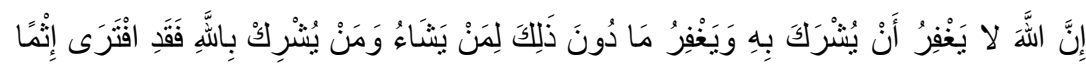

\footnotetext{
${ }^{84}$ Abu Isa Al-Tirmidzi, Sunan Al-Tirmidzi, ed. by Ahmad Muhammad Syakir Muhammad Fuad Abdul Baqi (Mesir: Shirkah Maktabah wa Matba'ah Al-Babi Al-Halbi, 1985). Vol.5, P.530

${ }^{85}$ Zakariya. P.113-120
} 
"Sesungguhnya Allah tidak akan mengampuni dosa syirik, dan Dia mengampuni segala dosa yang selain dari (syirik) itu, bagi siapa yang dikehendaki-Nya. Barangsiapa yang mempersekutukan Allah, Maka sungguh ia telah berbuat dosa yang besar". (An-Nisa': 48)

Manusia pada mulanya beragama dengan agama Nabi Adam AS yakni Tauhid, lalu mereka menyembah patung-patung pada masa Nuh AS, ${ }^{86}$ Al-Qur'an menyebutkan nama-nama sesembahan itu :

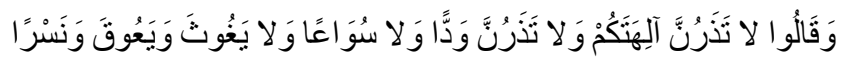

Dan mereka berkata: "Jangan sekali-kali kamu meninggalkan (penyembahan) tuhan-tuhan kamu dan jangan pula sekali-kali kamu meninggalkan (penyembahan) wadd, dan jangan pula suwwa', yaghuts, ya'uq dan nasr". (Nuh : 23)

Wadd, Suwwa', Yaghuts, Ya'uq dan Nasr adalah nama-nama orang saleh dari anak-anak Adam yang memiliki pengikut-pengikut. Namun ketika mereka mati para pengikut mereka membuat berhala mereka dengan tujuan agar lebih khusyuk dalam beribadah. Kemudian Iblis membisiki para pengikut itu, ketika mereka menyembah berhala turunlah hujan, lalu mereka beranggapan bahwa perbuatan itu benar dan melanjutkan model peribadatan tersebut hingga zaman Nabi Nuh AS. ${ }^{87}$

Syirik dibagi kedalam tiga perkara :

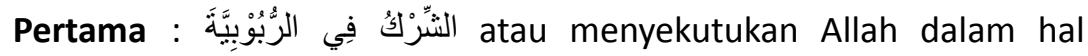
rububiyyah, menurut pelakunya Allah bukanlah satu-satunya pengatur dan pencipta alam semesta, yang memberi dan yang

${ }^{86}$ Abu Ja'far bin Jarir At-Thabari, Sahih Tarikhu T-Thabari, 1st edn (Beirut: Dar Ibnu Kathir, 2007). P.213-222

87 At-Thabari, Tafsir At-Thabari, Jami'u I-Bayan 'an Ta'Wil Ay I-Qur'an. $23 / 304$ 
menahan, yang memberi manfa'at dan bahaya dan ia mengharapkan apa yang mereka harapkan dari Allah. ${ }^{88}$ Syirik ini ada dua jenis :

1. Mengingkari Wujud Allah dan mempertanyakan wujud Allah seperti kaum Atheis, atau meyakini Allah sebagai pencipta namun tidak mempercayai bahwa Allah yang mengatur alam semesta.

2. Berkeyakinan bahwa Allah memiliki sekutu atau tidak sendirian dalam mengatur dan menciptakan alam semesta. ${ }^{89}$

Kedua : النشّرْكُ فِي الَْسَمَمَاءِ وَالصِّفَاتِ atau menyekutukan Allah dari segi nama dan sifat-Nya yang agung. Syirik ini ada dua jenisnya :

1. Mengingkari semua sifat Allah.

2. Menjadikan makhluq bersifat dengan sifat Allah atau menjadikan Allah bersifat dengan sifat makhluq. ${ }^{90}$

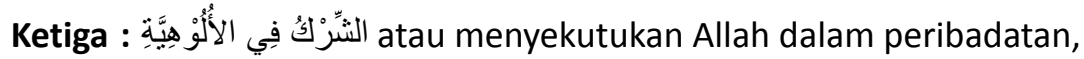
ketundukan, ketakutan, pengharapan dan penyembahan kepada selain Allah Swt. ${ }^{91}$ Syirik ini memiliki beberapa macam :

1. Syirik perbuatan, semisal : sujud kepada selain Allah, tawaf selain di Ka'bah, melakukan ritual-ritual dihadapan pohon, batu, laut, gunung, mencari ketetapan taqdir dengan berbagai cara, bertanya kepada dukun dan mempercayainya ketika ada masalah, mempercayai ucapan peramal, zodiak dan menggunakan jimat-jimat dsbg.

2. Syirik ucapan, semisal: berjanji dengan nama selain Allah "aku berjanji demi para leluhurku" dsbg, atau menyandingkan nama

\footnotetext{
${ }^{88}$ Ibnu Taimiyyah, Majmu' Fatawa. P.82

${ }^{89}$ Zakariya. P.141-143

${ }^{90}$ Zakariya. P.146-147

${ }^{91}$ Ibnu Taimiyyah, Majmu' Fatawa. P.71
} 
Allah dengan nama selain Allah "demi Allah dan para leluhurku", atau ucapan yang menyandingkan kekuasaan Allah dengan makhluqnya "cukup bagiku Allah dan dirimu."

3. Syirik niat, semisal: memohon pertolongan dan perlindungan kepada selain Allah SWT. ${ }^{92}$

Selain pembagian di atas ada juga yang disebut dengan syirik khafi atau tersembunyi. Syirik ini berupa riya' atau melakukan amalan untuk dilihat orang lain, hal ini sangat tersembunyi bahkan terkadang tidak terlihat bahwa itu bagian dari syirik. ${ }^{93}$ Rasullullah SAW Bersabda :

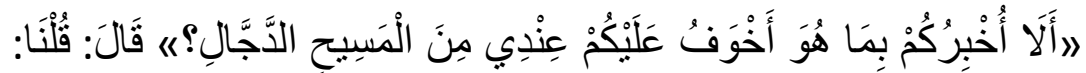

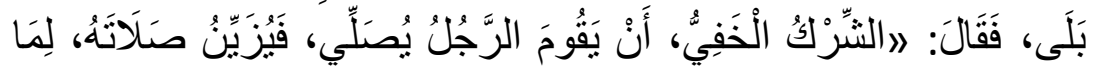
يَرَى مِنْ نَظَرِ رَجْلِ

"Bukankah telah aku beritahu tentang hal yang paling aku takuti dari Masih Dajjal ?", sahabat berkata: ya, Rasullulllah berkata : "Syirik yang tersembunyi, yakni seorang yang mendirikan shalat, kemudian memperindah shalatnya karena dilihat oleh orang lain. ${ }^{94}$

\section{AKHLAQ KEPADA ALLAH SWT}

Ketika seseorang mengimani Allah Swt, hal ini mengharuskan dirinya untuk berakhlaq dengan Allah Swt. Akhlaq kepada Allah jika diklasifikasi ada yang berkaitan dengan perbuatan kalbu, seperti: cinta, takut, mengharap, tawakkal, memohon pertolongan dsbg, kemudian perbuatan lisan, seperti: tidak berkata kecuali dengan apa yang Allah ridahi, berdzikir, membaca kitabnya dsbg, dan perbuatan

\footnotetext{
${ }^{92}$ Zakariya. P.147-155

${ }^{93}$ Zakariya. P.175

${ }^{94}$ Ibnu Majah, Sunan Ibnu Majah, 1st edn (Riyad: Maktabah I-Ma'arif). P.697
} 
tubuh dengan melakukan apa yang diperintahnya dan menjauhi apa yang dilarangnya. ${ }^{95}$ Akhlaq kepada Allah adalah bagian dari keimanan orang yang shalat, berkata baik, menghorrmati tamu dan tetangganya, berdzikir, membaca Al-Qur'an dsbg juga merupakan bagian dari keimanan. ${ }^{96}$ Pada bagian ini akan dijelaskan tentang beberapa akhlaq kepada Allah Swt.

\section{Mencintai Allah Swt (الحب)}

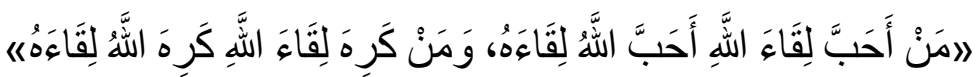

"Barang siapa yang cinta bertemu Allah, Allah akan cinta untuk bertemu dengannya, dan barang siapa benci untuk bertemu Allah, maka Allah akan benci untuk bertemu dengannya" ${ }^{97}$

Mencintai Allah Swt. merupakan bagian dari keimanan kepada Allah. Imam Bayhaqi lebih lanjut menyebutkan bahwa mencintai Allah, Rasulullah, dan jihad merupakan sesuatu yang wajib bagi orang yang beriman. Allah Swt berfirman:

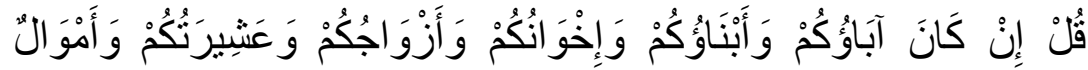

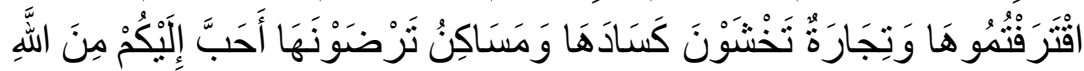

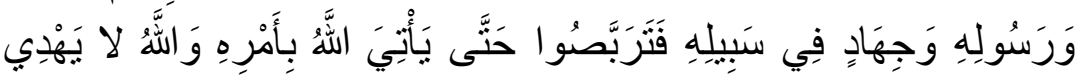

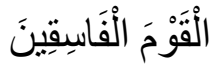

Katakanlah: "Jika bapa-bapa, anak-anak , saudara-saudara, isteri-isteri, kaum keluargamu, harta kekayaan yang kamu usahakan, perniagaan yang kamu khawatiri kerugiannya, dan tempat tinggal yang kamu sukai, adalah lebih kamu cintai dari Allah dan RasulNya dan dari berjihad di jalan nya,

${ }^{95}$ Khalid bin Jum'ah bin Uthman Al-Kharraz, Mausu'atu I-Akhlaq, 1st edn (Kuwait: Maktabah Ahli I-Athar, 2009). P. 121

${ }^{96}$ Al-Bayhaqi. 1/89-108

${ }^{97}$ Al-Bukhari.8/106 
Maka tunggulah sampai Allah mendatangkan keputusan NYA". dan Allah tidak memberi petunjuk kepada orang-orang yang fasik. (At-Taubah: 24)

Menurut Al-Halimi sebagaimana yang dikutip oleh Imam Al-Bayhaqi cinta kepada Allah memiliki beberapa makna, ${ }^{98}$ diantaranya:

1. Meyakini bahwa Allah Swt memiliki nama-nama yang terpuji,

2. Meyakini bahwa Allah selalu berbuat baik kepada hambanya,

3. Menyandarkan segala harapan hanya kepada Allah,

4. Hati hamba selalu berdzikir keepada Allah Swt,

5. Selalu bersikap tamak dalam melaksanakan kewajiban-kewajiban dan mendekat kepada Allah dengan melaksanakan hal-hal yang sunnah.

Kelompok sufi memaknai cinta kepada Allah yang hakiki adalah ketika hanya Allah saja yang ada dalam kalbu. Menurut Al-Syabli sebagaimana dikutip oleh Al-Qushairi, mendefinisikan cinta adalah ketika hilangnya semua apa yang ada di dalam kalbu kecuali sesuatu yang dicintai. ${ }^{99}$ Selanjutnya Dzun Nun Al-Mishri sebagaimana dikutip oleh Abu Nashr Sarraj Al-Tusi, ketika ditanya: "bagaimanakah cinta yang murni dan tidak keruh?", la menjawab: "cinta Allah yang murni adalah ketika cinta kepada segala sesuatu hilang dari kalbu dan seluruh tubuh, kemudian semuanya hanyalah bersama Allah dan untuk Allah, dan begitulah orang yang cinta kepada Allah." ${ }^{100}$ Ketika hadir cinta bagi kaum sufi maka semua sifat dan perbuatannya adalah perbuatan yang diridahi oleh Allah. ${ }^{101}$ Mengenai hal ini kaum sufi sering kali mengutip hadith qudsi:

\footnotetext{
${ }^{98}$ Al-Bayhaqi. 2/5-10

${ }^{99}$ Abu I-Qasim Al-Qushairi, Al-Risalah Al-Qushairiyyah, ed. by Abdu I-Halim Mahmud (Kairo: Daaru s-Sha'b, 1989). P. 522

100 Abu Nasr Sarraj Al-Tusi, Al-Luma' (Mesir: Daaru I-Kutub al-Hadithah, 1960). P.88.

${ }^{101}$ Al-Tusi.
} 


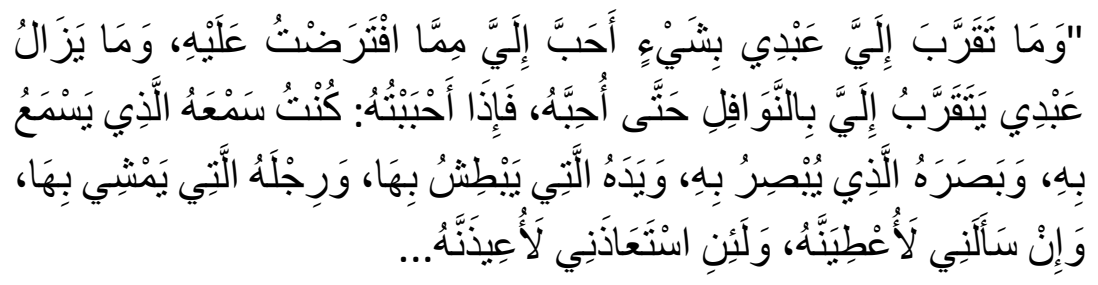

Dan hambaku akan mendekat kepada dengan melakukan hal-hal yang aku suka dan apa-apa yang aku wajibkan, dan hambaku selalu mendekat kepadaku dengan mengerjakan sunnah-sunnahhingga aku mencintainya, dan jika aku mencintainya aku adalah pendengarannya dengannya ia akan mendengar, aku adalah pengelihatannya dengannya ia melihat, dan tangannya dengannya ia menggenggam, dan kakinya dengannya ia berjalan, apabila ia meminta akan aku kabulkan, apabila meminta perlindunganku akan aku lindungi.... ${ }^{102}$

Hadith ini menunjukkan bahwa seorang hamba yang mencintai Allah akan mendekat kepada-Nya dengan berbagai amalan dan Allah akan mendekat juga kepadanya, hingga seluruh perbuatannya akan diiridahi oleh Allah karena bersesuaian dengan perintah Allah.

\section{Takut Kepada Allah (الخوف)}

Takut kepada Allah merupakan bagian dari pengakuan atas keagungan dan kebesaran Allah Swt, sehingga seorang hamba akan takut jika akan meninggalkan ketaatan kepada Allah. Hal ini sebagaimana takutnya rakyat kepada rajanya, takutnya anak kepada orang tuanya. Takutnya hamba kepada Allah juga karena adanya balasan nanti di akhirat bagi para pelaku dosa, Allah berfirman:

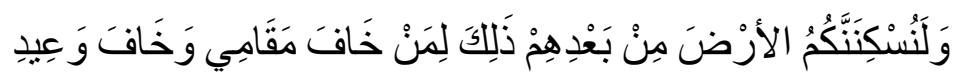

Dan Kami pasti akan menempatkan kamu di negeri-negeri itu sesudah mereka. yang demikian itu (adalah untuk) orang-orang yang takut (akan

${ }^{102}$ Al-Bukhari. 8/105 
menghadap) kehadirat-Ku dan yang takut kepada ancaman-Ku". (Ibrahim:14)

Takut kepada Allah akan menghasilkan sikap 'Iffah yaitu sikap pengendalian diri dari melakukan hal-hal yang terlarang. 'Iffah dapat terjadi jika ada penghalang dalam diri yang memaksa untuk meninggalkan sesuatu. Hal ini bisa dilihat dari kisah nabi Yusuf As yang digoda oleh wanita namun karena takut kepada Allah ia pun bersikap 'iffah. ${ }^{103}$

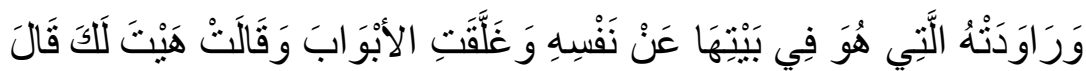

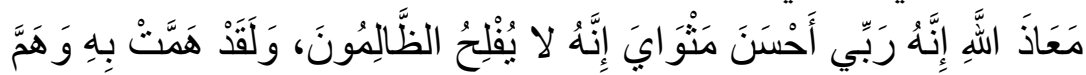

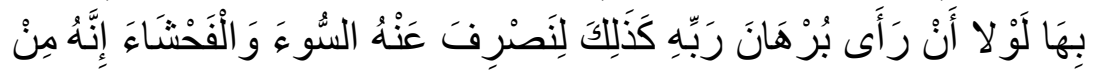

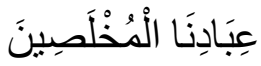

Dan wanita (Zulaikha) yang Yusuf tinggal di rumahnya menggoda Yusuf untuk menundukkan dirinya (kepadanya) dan Dia menutup pintu-pintu, seraya berkata: "Marilah ke sini." Yusuf berkata: "Aku berlindung kepada Allah, sungguh tuanku telah memperlakukan aku dengan baik." Sesungguhnya orang-orang yang zalim tiada akan beruntung. Sesungguhnya wanita itu telah bermaksud (melakukan perbuatan itu) dengan Yusuf, dan Yusufpun bermaksud (melakukan pula) dengan wanita itu andaikata Dia tidak melihat tanda (dari) Tuhannya. Demikianlah, agar Kami memalingkan dari padanya kemungkaran dan kekejian. Sesungguhnya Yusuf itu Termasuk hamba-hamba Kami yang terpilih. (Yusuf:24-25)

Mengharap Kepada Allah (الرجاء)

Sikap mengharap berkaitan dengan sikap takut, karena orang yang takut akan berharap agar sesuatu yang ditakuti tidak terjadi. Orang yang takut itu akan mengharapkan perlindungan kepada Allah

\footnotetext{
${ }^{103}$ Abdu r-Rahman Hasan Habankah Al-Maydani, Al-Akhlaq Al-Islamiyyah Wa Ususuha, 5th edn (Damaskus: Daaru I-Qalam, 1999). 2/581-583
} 
Swt. Untuk memperjelas hal tersebut Allah Swt menyebutkan kaitannya dalam surah Al-A'raf:56.

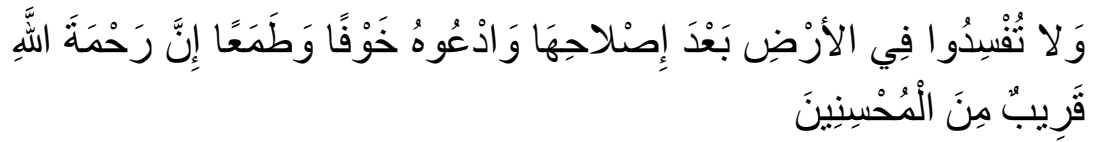

Dan janganlah kamu membuat kerusakan di muka bumi, sesudah (Allah) memperbaikinya dan berdoalah kepada-Nya dengan rasa takut (tidak akan diterima) dan harapan (akan dikabulkan). Sesungguhnya rahmat Allah Amat dekat kepada orang-orang yang berbuat baik.

Kemudian menurut Al-Halimi mengharap memiliki beberapa bentuk: Mengharap untuk memperoleh apa yang diinginkan dan mencapai sesuatu yang dicintai, dan mengharap agar selalu bersama sesuatu yang diinginkan setelah dicapai. Kemudian mengharap agar tidak terjadi sesuatu yang dibenci dan berusaha menghilangkannya agar tidak terjadi, dan jika sesuatu yang dibenci sudah terjadi diharapkan agar segera sirna. ${ }^{104}$ Disini manusia selalu mengharap untuk mencapai sesuatu yang baik dan takut jika sesuatu yang buruk menimpanya. Jika dikaitkan dengan keimanan maka manusia yang beriman agar selalu mengharapkan ampunan dan rido dari Allah dan selalu takut terhadap adzab Allah Swt. ${ }^{105}$

$$
\text { وَيَرْجُونَ رَحْمَتَهُوَيَخَافُونَ عَذَابَهُ إِنَّ عَذَابَ رَبِّكَ كَانَ مَحْذُورًا }
$$

Dan mengharapkan rahmat-Nya dan takut akan azab-Nya; Sesungguhnya azab Tuhanmu adalah suatu yang (harus) ditakuti. (Al-Isra':57)

Namun jika mengharap ampunan dan rido Allah maka seseorang harus melakukan konsekwensi dari itu semua yakni berbuat apa yang Allah perintah dan menjauhi larangannya.

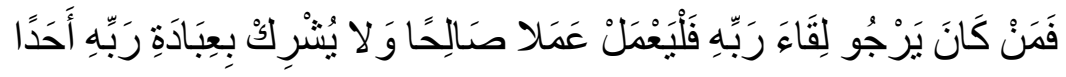

${ }^{104}$ Al-Bayhaqi. 2/319

${ }^{105}$ Al-Tusi. P.91 
“Barangsiapa mengharap perjumpaan dengan Tuhannya, Maka hendaklah ia mengerjakan amal yang saleh dan janganlah ia mempersekutukan seorangpun dalam beribadat kepada Tuhannya". (Al-Kahfi: 110)

Taqwa (التقوى)

Seluruh Rasul dari Nabi Adam As hingga Nabi Muhammad Saw menyerukan kepada iman dan taqwa. Iman sebagaimana yang sudah dijelaskan adalah keyakinan sedangkan taqwa adalah implikasi وقى - dari keimanan tersebut. Taqwa secara bahasa berasal dari kata yang berarti menjaga, maksudnya adalah menjaga diri dari neraka, sebagaimana firman Allah:

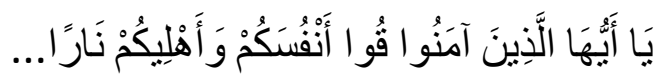

Hai orang-orang yang beriman, jagalah dirimu dan keluargamu dari api neraka...(At-Tahrim: 6)

Kemudian "bagaimanakah seseorang dapat menjauhkan dirinya dari neraka? Tentunya caranya adalah dengan mematuhi semua perintah Allah dan menjauhi larangan-Nya. Inilah definisi taqwa secara terminologi.

Seorang muslim yang mengikrarkan kalimat laa ilaaha illa Ilah mengharuskan hadirnya kalimat ini dalam sikap dan cara pandangnya dalam memandang dunia. Oleh karenanya kalimat laa ilaaha illa llah disebut juga sebagai kalimat tayyibah (Ibrahim:26) dan juga disebut dengan kalimatu t-taqwa, ${ }^{106}$ Allah berfirman:

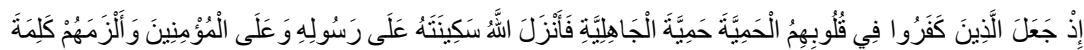

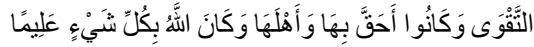

Ketika orang-orang kafir menanamkan dalam hati mereka kesombongan (yaitu) kesombongan Jahiliyah lalu Allah menurunkan ketenangan kepada

106 Umar Sulaiman Al-Ashqari, At-Taqwa; Ta'rifuha Wa Fadluha Wa Mahdhuratuha Wa Qishashu Min Ahwaliha, 1st edn (Omman: Daaru n-Nafa'is, 2012). P.23-27 
Rasul-Nya, dan kepada orang-orang mukmin dan Allah mewajibkan kepada mereka kalimat takwa dan adalah mereka berhak dengan kalimat takwa itu dan patut memilikinya. Dan adalah Allah Maha mengetahui segala sesuatu. (Al-Fath:26)

Kalimat laa ilaaha illa llah merupakan kalimat yang penting karena menjadi basis dari Islam dan merupakan kalimat yang menjadi tujuan dari dakwah semua nabi dan rasul sejak zaman Adam As hingga Muhammad Saw. Bagi seorang yang beriman kalimat ini tidak hanya menjadi kalimat yang hanya terpatri di kalbu dan terucapkan di lisan saja, namun lebih dari itu ia adalah kalimat yang menuntun setiap ucapan, perbuatan, sikap, langkah seorang mu'min. Atau dengan kata lain keimanan kepada Allah mengharuskan adanya ketaqwaan baik dalam dalam perbuatan yang tersembunyi atau perbuatan yang nampak. Sebagaimana ungkapan Wahab bin Manbah yang diriwayatkan oleh Abi Dunya:

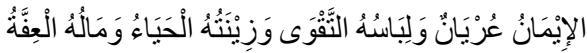

"Iman itu telanjang, dan pakaiannya adalah taqwa, perhiasannya adalah malu, dan hartanya adalah "iffah" 107

Maka hukum taqwa adalah wajib bagi seorang yang beriman. Karena wajib maka wajib pula hukumnya bagi seorang muslim untuk mempelajari apa saja yang harus di lakukan dan ditinggalkan untuk mencapai derajat muttaqiin (orang-orang yang bertaqwa). ${ }^{108}$

Secara umum ada beberapa hal yang harus diperhatikan bagi seorang mu'min agar dia selalu bertaqwa: ${ }^{109}$

1. la harus bertaqwa dari kekufuran dan kesyirikan,

\footnotetext{
${ }^{107}$ Abu Dunya, Makarimu L-Akhlaq (Bulaq: Maktabah Al-Qur'an, 1990). P.41

108 Muhammad Shalih Al-Munjid, A'malu I-Qulub; At-Taqwa, 1st edn (Jeddah: Zad Group, 2009). P. 13, 27, 40

109 Al-Ashqari, At-Taqwa; Ta'rifuha Wa Fadluha Wa Mahdhuratuha Wa Qishashu Min Ahwaliha. P.31-33
} 
2. Ia harus bertaqwa dari perbuatan bid'ah atau perkara yang dibuat-buat dalam masalah agama dan tidak ada contohnya dalam Al-Qur'an dan Al-Hadith,

3. la harus bertaqwa dari perbuatan dosa besar (kaba'ir),

4. la harus bertaqwa dari perbuatan dosa kecil (shagha'ir),

5. la harus bertaqwa dari sesuatu yang diperbolehkan (mubah) agar tidak terlalu terlena karena dapat membawanya kepada yang haram,

6. Ia harus bertaqwa dari perbuatan yang terlihat seolah-olah sebagai ketaatan yang utama, namun pada dasarnya syaithan menghiasai di matanya seolah-olah hal itu adalah yang paling utama, kemudian ia menjadi penghalang untuk ketaatan lainnya yang lebih utama.

Bertaqwa akan memberikan pengaruh dalam diri manusia baik pengaruh dari segi agama, kehidupan dunia, dan kehidupan di akhirat. ${ }^{110}$ Dari segi agama seorang muttaqin akan memiliki watak Al-Furqan, yaitu sikap mampu membedakan yang benar dan yang salah.

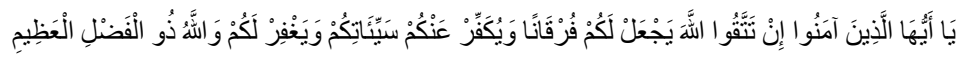
Hai orang-orang beriman, jika kamu bertaqwa kepada Allah, Kami akan memberikan kepadamu Furqaan. Dan Kami akan jauhkan dirimu dari kesalahan-kesalahanmu, dan mengampuni (dosa-dosa)mu. dan Allah mempunyai karunia yang besar. (Al-Anfal: 29)

Kemudian orang yang bertaqwa akan memperoleh hidayah, nasehat-nasehat, dan pengingat dengan membaca Al-Qur'an.

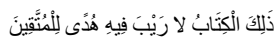

Kitab Al Quran ini tidak ada keraguan padanya; petunjuk bagi mereka yang bertaqwa (Al-Baqarah: 2)

110 Muhammad Ad-Dabsy, At-Taqwa Fi I-Qur'ani I-Karim; Dirasah Fi Tafsir Al-Maudu'i, 1st edn (Kairo: Daaru I-Muhaddithin, 2008). P.427 
Hal ini dikarenakan mereka mendengarkan dan menghayati ayat-ayat tersebut, hal ini adalah sikap seorang mu'min ketika dibacakan ayat-ayat Allah;

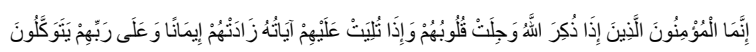

Sesungguhnya orang-orang yang beriman ialah mereka yang bila disebut nama Allah gemetarlah hati mereka, dan apabila dibacakan ayat-ayatNya bertambahlah iman mereka (karenanya), dan hanya kepada Tuhanlah mereka bertawakkal. (Al-Anfal:2)

Kemudian sifat taqwa juga memberikan pengaruh bagi kehidupan di dunia. Diantaranya adalah dilancarkan rezekinya dan berbagai urusannya. Hal ini sebagaimana yang disebutkan dalam surah At-Thalaq:

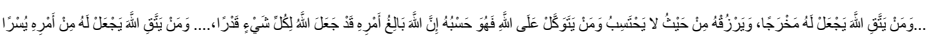

....Barangsiapa bertakwa kepada Allah niscaya Dia akan Mengadakan baginya jalan keluar. Dan memberinya rezeki dari arah yang tiada disangka-sangkanya. dan Barangsiapa yang bertawakkal kepada Allah niscaya Allah akan mencukupkannya. Sesungguhnya Allah melaksanakan urusan yang (dikehendaki)Nya. Sesungguhnya Allah telah Mengadakan ketentuan bagi tiap-tiap sesuatu...... Dan barang -siapa yang bertakwa kepada Allah, niscaya Allah menjadikan baginya kemudahan dalam urusannya. (At-Thalaq: 2-4)

Selain itu pengaruh lain bagi kehidupan dunia adalah; diselamatkan dari adzab dunia (Fushilat:18); diturunkannya malaikat untuk meneguhkan kalbu orang yang bertaqwa dan melindunginya (Ali Imron:125); Allah akan menjaganya dan menolongnya dari berbagai musuh (Ali Imron:120).

Sedangkan pengaruh taqwa bagi kehidupan di akhirat antara lain: turunnya malaikat ketika diakhirat (Yunus 62-64); diselamatkan dari api neraka (Maryam: 71-72, 85-86); akan ditutupi kesalahannya dan diberikan kebaikan yang besar (Ali Imron 172, 179, At-Thalaq:5); 
diberikan posisi yang tinggi di akhirat (Al-Baqarah:212); kekal di dalam surga (Ad-Dukhan: 51-57, Al-Tur: 17-24, An-Naba': 31-36).

\section{BAB III}

\section{AN-NUBUWWAT}

Meyakini kebenaran nabi-nabi dan rasul-rasul Allah merupakan syarat dari sempurnanya Iman seseorang. Karena manusia tidak akan bisa mengetahui syari'at yang diridohi oleh Allah Swt, kecuali melalui khabar shadiq atau kabar yang benar, yang berasal dari para nabi dan rasul, dan kitab-kitab yang diturunkan kepada mereka.

Pada bab ini akan dibahas mengenai nabi dan rasul terkait erat dengan pembahasan mu'jizat, dan sihir, juga dengan pembahasan kitab-kitab yang Allah turunkan kepada para rasul-Nya. Kemudian dilanjutkan dengan pembahasan akhlaq kepada Nabi Saw dan Al-Qur'an

\section{IMAN KEPADA NABI DAN RASUL}

\section{Definisi Nabi, Rasul, dan Wali}

Kata nabi berasal dari kata "“َبََ artinya memberi kabar, hal ini karena nabi memberi kabar kepada manusia. Selain itu kata nabi

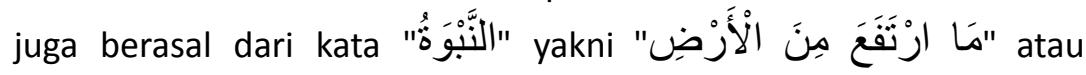
sesuatu yang tinggi dari bumi. Maka makna dari Nabi itu sendiri adalah orang yang keutamaan dan derajat yang tinggi di bumi dan di langit, serta mendapatkan wahyu, lalu mengkabarkan apa yang di wahyukan kepada manusia. 
Kata rasul berarti utusan, atau orang yang menyampaikan wahyu dari Allah Swt. Mereka adalah orang yang diutus membawa risalah tertentu, dan diberikan beban untuk menyampaikan risalah Allah kepada manusia. ${ }^{111}$

Sedangkan wali menurut Imam Al-Jurjani adalah orang yang mengenal dan mengetahui Allah dan sifat-sifat Nya, pengetahuan ini diperoleh karena ia teguh dan tekun dalam ketaatan kepada Allah dan menjauhi kemaksiatan, dan juga bersungguh-sungguh dalam menjauhi kenikmatan dan syahwat. ${ }^{112}$

Para ulama' berbeda pendapat tentang "perbedaan rasul dan nabi", diantara pendapat-pendapatnya antara lain:

Pertama: menyamakan makna rasul dan nabi, jadi setiap nabi adalah rasul, dan setiap rasul adalah nabi.

Kedua: membedakan antara rasul dan nabi, dan mengatakan bahwa rasul lebih tinggi dari nabi, jadi setiap rasul adalah nabi dan bukan setiap nabi adalah rasul, perbedaannya antara lain :

1. Turunnya wahyu kepada rasul melalui malaikat Jibril, sedangkan turunnya wahyu kepada nabi melalui mimpi.

2. Rasul diutus kepada suatu ummat atau bangsa, sedangkan nabi tidak diutus kepada suatu bangsa.

3. Rasul adalah diutus dengan membawa syari'at yang baru, sedangkan nabi diutus untuk menjaga dan melestarikan syari'at yang ada sebelumnya. ${ }^{113}$

${ }^{111}$ Al-Ashqari, Al-'Aqidah 'Ala Dau'i I-Kitab Wa Sunnah. 4/13-14

112 Al-Jurjani. P.213

113 Abu Hasan Ali bin Muhammad Al-Mawardi, A'laamu n-Nubuwwah, 1st edn (Beirut: Daaru I-Kutub al-Ilmiyyah, 1986). P.34. 
Selain tiga perbedaan di atas, ada juga ulama' yang mengatakan bahwa perbedaannya adalah rasul merupakan orang yang mendapatkan wahyu untuk disampaikan kepada manusia, sedangkan nabi adalah orang yang mendapatkan wahyu untuk dirinya sendiri. Namun pendapat ini lemah, karena Allah tidaklah mengirimkan wahyu kecuali untuk disampaikan.

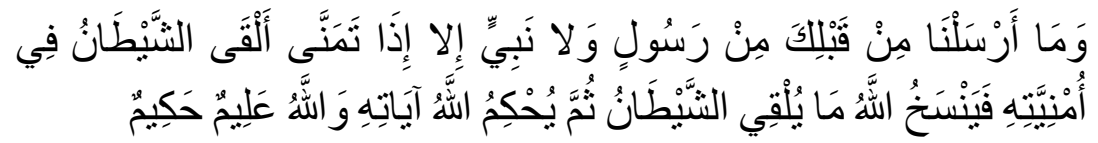

"Dan Kami tidak mengutus sebelum kamu seorang Rasul pun dan tidak (pula) seorang Nabi, melainkan apabila ia mempunyai sesuatu keinginan, syaitanpun memasukkan godaan-godaan terhadap keinginan itu, Allah menghilangkan apa yang dimasukkan oleh syaitan itu, dan Allah menguatkan ayat-ayat- nya. dan Allah Maha mengetahui lagi Maha Bijaksana". (Al-Hajj: 52)

Maksudnya adalah ketika rasul dan nabi diutus oleh Allah SWT, dan akan membacakan ayat-ayat Allah, syetan akan mengganggu dalam fikiran para rasul dan nabi. Berdasarkan ayat ini dapat dipahami bahwa Allah tidak hanya mengutus rasul saja, namun Allah mengutus nabi dan rasul keduanya untuk menyampaikan ayat-ayat Allah SWT. ${ }^{114}$

Sedangkan "wali" bersifat lebih umum lagi, bahwa setiap nabi dan rasul itu wali, namun tidak setiap wali itu nabi dan rasul.

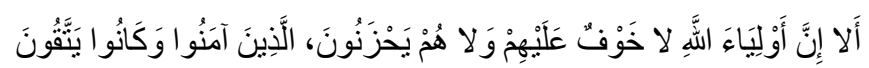

Ingatlah, Sesungguhnya wali-wali Allah itu, tidak ada kekhawatiran terhadap mereka dan tidak (pula) mereka bersedih hati. (yaitu) orang-orang yang beriman dan mereka selalu bertakwa. (Yunus:62-63)

Sifat Nabi Dan Rasul 
Diantara sifat-sifat nabi dan rasul, sebagaimana yang disebutkan oleh Al-Ashqari adalah sebagai berikut:

Pertama, nabi dan rasul itu adalah manusia, bukan malaikat karena dengan sebab-sebab berikut:

1. Sebagai ujian bagi manusia,

2. Manusia lebih pantas dan lebih jelas sebagai contoh bagi manusia lainnya,

3. Selain itu manusia sulit untuk melihat malaikat. Oleh karena itu nabi dan rasul seperti manusia lainnya, mereka makan dan minum, mereka tidur dan bangun, mereka sakit dan sehat, dan juga mereka pasti mati.

Kedua, karena nabi dan rasul adalah manusia, maka, tidak ada satupun karakteristik ketuhanan yang menempel pada dirinya. Maka menuhankan salah satu rasul adalah bentuk kekufuran.

Ketiga, nabi dan rasul memiliki akhlaq yang sempurna, sehingga ia dapat menjadi contoh bagi manusia yang lainnya. Yang sering disebut sebaga akhlaq para nabi adalah: sidiq/jujur, tabligh/menyampaikan, amanah/selalu menjaga amanah, dan fatonah/cerdas.

Keempat, nabi dan rasul memiliki tubuh yang lebih kuat dari manusia lainnya.

Kelima, nabi dan rasul memiliki bentuk tubuh yang sempurna.

Keenam, nabi dan rasul adalah orang yang memiliki nasab yang terbaik.

Ketujuh, nabi dan rasul diberikan karunia yang sempurna, mereka memiliki akal yang lebih tinggi, kecerdasan yang luar biasa, dan ucapan yang jelas. 
Kedelapan, nabi dan rasul adalah manusia yang paling mencintai 'Ibadah.

Kesembilan, nabi dan rasul adalah laki-laki, ada pendapat yang mengatakan bahwa ada nabi dari kalangan wanita, seperti Maryam, Asiyah dan Ibu Musa, namun pendapat ini lemah karena mereka tidak diperintahkan untuk menyampaikan wahyu. Walaupun demikian, mereka juga memiliki tingkatan yang terhormat sebagai wali Allah. ${ }^{115}$

\section{Nama Dan Jumlah Nabi Dan Rasul}

Allah Swt menyebutkan jumlah nabi dan rasul-Nya dalam Al-Qur'an, kemudian para ulama' mensepakati sejumlah 25 rasul. ${ }^{116}$ Mereka adalah: Adam AS, Idris AS, Nuh AS, Hud AS, Sholeh AS, Ibrahim AS, Luth AS, Ismail AS, Ishaq AS, Ya'kub AS, Yusuf AS, Ayub AS, Syu'aib AS, Musa AS, Harun AS, Zulkifli AS, Daud AS, Sulaiman AS, Ilyas AS, Ilyasa AS, Yunus AS, Zakariya AS, Yahya AS, Isa AS, dan Muhammad SAW.

Allah menyebutkan 18 nama rasul di satu tempat yang sama surah Al-An'am 83-86:

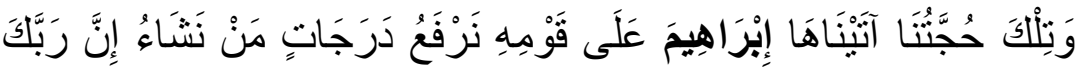

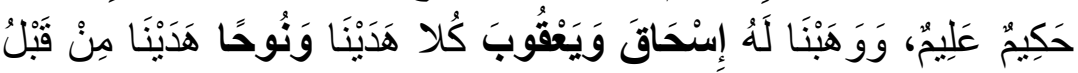

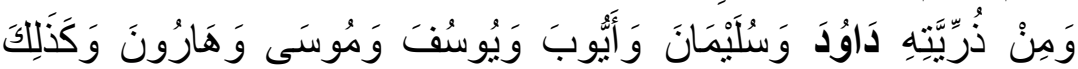

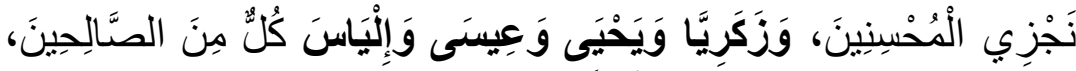

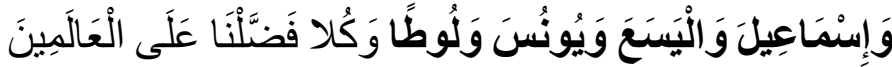

"Dan Itulah hujjah Kami yang Kami berikan kepada Ibrahim untuk menghadapi kaumnya. Kami tinggikan siapa yang Kami kehendaki beberapa

\footnotetext{
${ }^{115}$ Al-Ashqari, Al-'Aqidah 'Ala Dau'i I-Kitab Wa Sunnah. 4/70-85

${ }^{116}$ Al-Ashqari, Al-'Aqidah 'Ala Dau'i I-Kitab Wa Sunnah. 4/18
} 
derajat. Sesungguhnya Tuhanmu Maha Bijaksana lagi Maha mengetahui. Dan Kami telah menganugerahkan Ishak dan Yaqub kepadanya. kepada keduanya masing-masing telah Kami beri petunjuk; dan kepada Nuh sebelum itu (juga) telah Kami beri petunjuk, dan kepada sebahagian dari keturunannya (Nuh) Yaitu Daud, Sulaiman, Ayyub, Yusuf, Musa dan Harun. Demikianlah Kami memberi Balasan kepada orang-orang yang berbuat baik. Dan Zakaria, Yahya, Isa dan Ilyas. semuanya Termasuk orang-orang yang shaleh. Dan Ismail, Alyasa', Yunus dan Luth. masing-masing Kami lebihkan derajatnya di atas umat (di masanya)"

Dan Allah menyebutkan nama Adam, Hud, Salih, Syu'aib, Isma'il, Idris, Dzulkifli, dan Muhammad di tempat yang berbeda-beda:

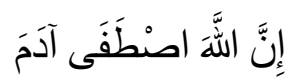

"Sesungguhnya Allah telah memilih Adam" (Ali Imran : 33)

$$
\text { وَ إلَلَى عَادِ أَخَاهُمْ هُودًا }
$$

“Dan kepada kaum 'Ad (kami utus) saudara mereka, Huud." (Hud:

50)

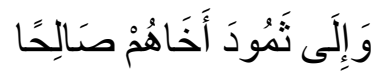

“Dan kepada Tsamud (kami utus) saudara mereka shaleh." (Hud: 61)

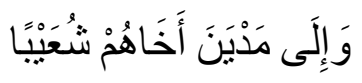

"Dan kepada (penduduk) Mad-yan (kami utus) saudara mereka, Syu'aib." (Hud: 84)

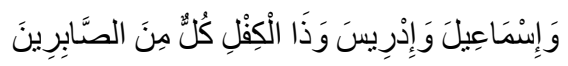

"Dan (ingatlah kisah) Ismail, Idris dan Dzulkifli. semua mereka Termasuk orang-orang yang sabar." (Al-Anbiya': 85)

$$
\text { مُحَمَّدُ رَسُولُ اللَّهِ }
$$


Muhammad itu adalah utusan Allah . (Al-Fath: 29)

Dari ke-25 nabi itu ada 5 nabi yang disebut dengan ulu I-azmi: atau nabi yang memiliki kesabaran dan kekuatan yang luar biasa dalam menghadapi kaumnya.

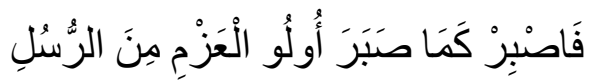

Maka bersabarlah kamu seperti orang-orang yang mempunyai keteguhan hati dari Rasul-rasul telah bersabar (Al-Ahqaf: 35)

Dan Ulul-Azmi Itu antara lain Nuh AS, Ibrahim AS, Musa AS, Isa AS, Muhammad SAW, berdasarkan dalil:

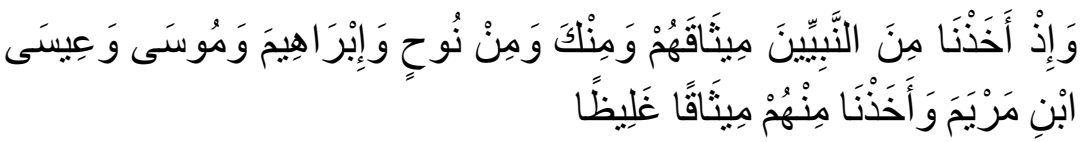

"Dan (ingatlah) ketika Kami mengambil Perjanjian dari nabi-nabi dan dari kamu (sendiri) dari Nuh, Ibrahim, Musa dan Isa putra Maryam, dan Kami telah mengambil dari mereka Perjanjian yang teguh" (Al-Ahzab : 7)

Selain 25 nama nabi dan rasul diatas, ada juga nama-nama di dalam Al-Qur'an yang diperdebatkan kenabiannya dikalangan ulama' seperti ‘Uzair, Dzu I-Qarnayn, dan Khidir.

Selain nama-nama yang disebutkan di Al-Qur'an ada juga nama nabi yang disebutkan di dalam Hadith, diantaranya adalah Nabi Syits/Set/ شيث:ثنيت bin Adam AS dalam sebuah riwayat yang lemah disebutkan bahwa telah diturunkan kepadanya 50 lembaran. 117 Juga ada Nabi Yusya' bin Nuun (يوسع بن نون), Syam'un/Samuel AS (شامول/شعون), Danial AS (دانيال).

117 Isma'il bin Kathir, Al-Bidaayah Wa n-Nihaayah, 1st edn (Giza: Daaru I-Hijr, 1997).1/230

${ }^{118}$ Kathir. 2/385 
Sedangkan jumlah nabi dan rasul seluruhnya jika dirujuk kepada Hadith lemah riwayat Ibnu Hibban adalah 124.000 nabi dan jumlah rasul 313 dari jumlah keseluruhan nabi:

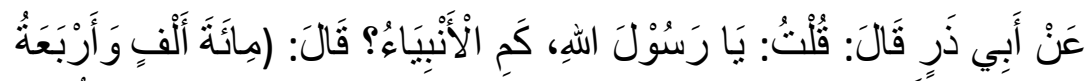

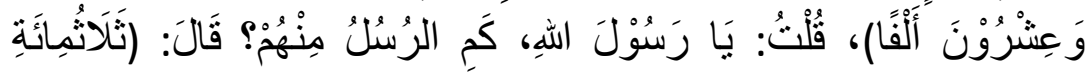

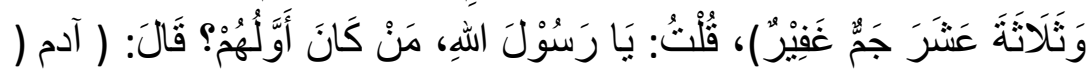

"Dari Abi Dzar berkata: aku berkata: "Wahai Rasulullah berapa jumlah nabi-nabi?" Rasullullah berkata: "124.000", lalu aku berkata: "Wahai Rasulullah berapa jumlah Rasul dari mereka: "313" lalu aku berkata: "Wahai Rasulullah siapakah yang paling awal?" la Saw berkata: “Adam"119

Hadith ini tidak bisa dijadikan sandaran karena lemahnya periwayatan, dan belum ada sumber yang menjadi rujukan untuk mengetahui jumlah nabi dan rasul. Namun umat muslim cukup meyakini bahwa Allah telah mengutus kepada setiap kaum seorang rasul :

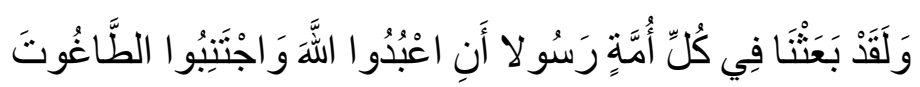

"Dan sungguh Kami telah mengutus Rasul pada tiap-tiap umat (untuk menyerukan): "Sembahlah Allah (saja), dan jauhilah Thaghut itu"...(An-Nahl :36)

Cukup bagi umat Islam untuk meyakini itu, karena ada nabi dan rasul yang sudah diberitahukan namanya dan ada pula yang belum diberitahukan namanya:

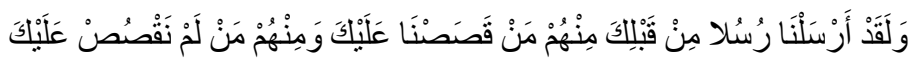

${ }^{119}$ Kathir. $1 / 226$ 
"Dan Sesungguhnya telah Kami utus beberapa orang Rasul sebelum kamu, di antara mereka ada yang Kami ceritakan kepadamu dan di antara mereka ada (pula) yang tidak Kami ceritakan kepadamu..." (Ghafir/Al-Mu'min:78)

\section{Wahyu}

Setiap nabi dan rasul akan memperoleh wahyu dari Allah SWT. Wahyu adalah pengabaran/ pemberitaan dari Allah kepada para nabi dan rasul-Nya melalui cara yang berbeda-beda. Adapaun cara-cara sampainya wahyu kepada para nabi dan rasul sebagaimana yang telah disebutkan di surah Al-Syura: 51 :

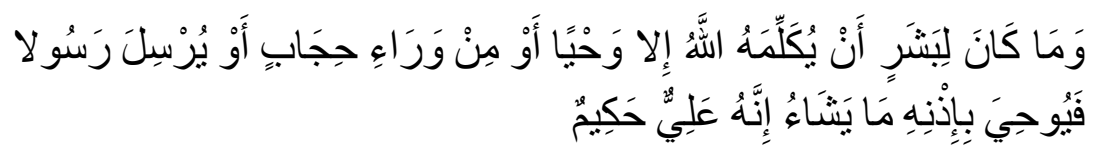

"Dan tidak mungkin bagi seorang manusiapun bahwa Allah berkata-kata dengan Dia kecuali dengan perantaraan wahyu atau dibelakang tabir, atau dengan mengutus seorang utusan (malaikat) lalu diwahyukan kepadanya dengan seizin-Nya apa yang Dia kehendaki. Sesungguhnya Dia Maha Tinggi lagi Maha Bijaksana."

Melalui ayat ini dapat disimpulkan 3 cara turunnya wahyu kepada para nabi dan rasul:

1. Allah SWT menyampaikan wahyu kepada nabi-Nya langsung kedalam jiwanya. Termasuk juga dengan mimpi, dan mimpi para nabi dan rasul adalah benar-benar datang dari Allah SWT.

2. Allah menyampaikan wahyu secara langsung hanya berbatas tabir atau hijab antara Allah dan nabi-Nya. Sebagaimana wahyu yang disampaikan kepada Musa AS di gunung Sinai, kepada Adam AS diajarkan nama-nama, Mabi Muhammad SAW ketika naik kelangit ke tujuh dan mendapatkan perintah shalat. 
3. Allah SWT menyampaikan wahyu melalui Malaikat Jibril AS.

\section{Mu'jizat, Karamah, Dan Sihir}

Setiap nabi dan rasul diberikan kemampuan khusus oleh Allah Swt untuk membuktikan bahwa dirinya benar-benar utusan Allah, kemampuan ini disebut dengan mu'jizat.

Mu'jizat secara etimologi berasal dari kata 'ajaza (عجز) yang berarti lemah, secara terminonolgi adalah "kemampuan yang Allah berikan kepada nabi dan rasul-Nya di luar batas kemampuan manusia dan melampaui keadaan yang biasa berlaku, bertujuan untuk melawan berbagai tantangan dalam dakwah, tanpa ada satupun yang mampu untuk melawannya."

Karakteristik terpenting dari mu'jizat antara lain:

1. Khusus untuk nabi dan rasul,

2. Datangnya dari Allah Swt bukan dari manusia,

3. Mu'jizat tidak mungkin dilawan dengan segala daya dan upaya,

4. Mu'jizat melampaui hukum-hukum alam dan hukum akal.

Semua nabi dan rasul diberikan mu'jizat oleh Allah SWT, diantara mu'jizat itu adalah: Nabi Ibrahim yang tidak terbakar terkena api, Nabi Musa yang membelah Laut Merah, Nabi Isa menyembuhkan penyakit kusta dan menghidupkan orang mati, Nabi Muhammad yang membelah bulan dan Al-Qur'an sebagai kitab terakhir; tidak ada satu orang pun di muka bumi ini yang mampu membuat yang semisal dengannya.

Jika mu'jizat diturunkan kepada nabi dan rasul, ada juga hal-hal melampaui batas yang diturunkan kepada para wali ini adalah karamah. Karamah adalah "kemampuan yang Allah berikan kepada para wali-Nya di luar batas kemampuan manusia dan melampaui 
keadaan yang biasa berlaku, untuk membuktikan kebenaran agama-Nya dan kebenaran rasul yang diikutinya."

Karamah ini benar adanya, misalkan: Maryam yang mendapatkan makanan/ rizqi dari Allah dalam mihrabnya, Ashabu I-Kahfi yang tidur selama 309 tahun. Dan ada juga kisah-kisah yang menunjukkan para sahabat seperti Khalid bin Walid yang meminum racun dan tidak mati, Umar bin Khattab yang mengirimkan surat kepada Nil untuk tidak meluap lagi dsbg.

Berbeda dengan mu'jizat dan karamah, sihir merupakan hal yang terlihat di melampaui kemampuan manusia dan hukum sebab akibat, namun pada hakekatnya sihir masih pada jangkauan manusia dan jin. Namun bagi orang kebanyakan sihir adalah perkara yang melampaui batas. Proses terjadinya sihir adalah karena adanya penyembahan dan permohonan tolong dari manusia kepada jin. Al-Qur'an menyebutkan:

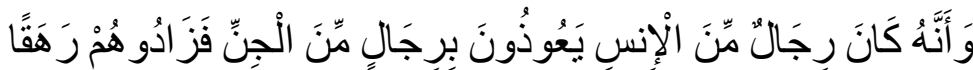

"Dan bahwasanya ada sebagian kelompok manusia yang memohon perlindungan dengan sekelompok dari jin, maka bertambahlah kesesatannya." (Al-Jin: 6)

Karena sihir datang dari jin, tentunya ia tidak akan mampu mengalahkan mu'jizat dan karamah yang berasal dari Allah SWT, hal ini dibuktikan dengan kisah nabi Musa yang mengalahkan para penyihir Fir'aun (Taha: 57-71).

\section{IMAN KEPADA KITAB-KITAB ALLAH}

Mengimani kitab-kitab Allah dan lembaran-lembaran yang diturunkan kepada para nabi dan rasul, merupakan syarat dari keimanan seorang mu'min. Isi dari ajaran para rasul terkandung 
dalam kitab-kitab dan lembaran-lembaran ini, maka mengimaninya berarti mengimani kebenaran para nabi dan rasul, mengingkarinya berarti mengingkari kebenaran ajaran mereka. Allah Swt berfirman:

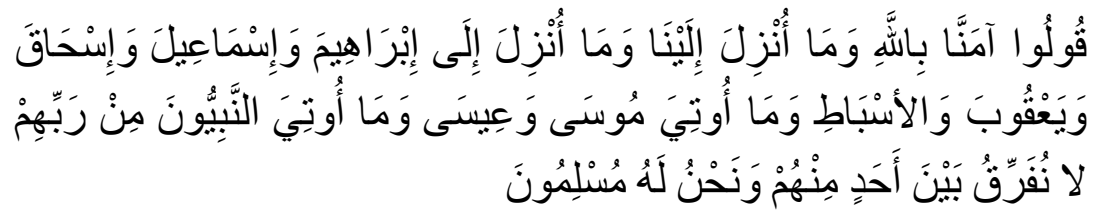

Katakanlah (hai orang-orang mukmin): "Kami beriman kepada Allah dan apa yang diturunkan kepada Kami, dan apa yang diturunkan kepada Ibrahim, Isma'il, Ishaq, Ya'qub dan anak cucunya, dan apa yang diberikan kepada Musa dan Isa serta apa yang diberikan kepada nabi-nabi dari Tuhannya. Kami tidak membeda-bedakan seorangpun diantara mereka dan Kami hanya tunduk patuh kepada-Nya". (Al-Baqarah: 136)

Kitab (الكتاب) secara etimologi berarti "pembahasan yang dikumpulkan dan digabungkan" (ما جمع وضمّ), secara terminologi adalah "apa-apa yang dikumpulkan dan digabungkan dalam sebuah kitab berisikan wahyu yang diturunkan Allah kepada para nabi dan rasul-Nya."

Selain berupa kitab, Allah Swt juga menurunkan kepada beberapa nabi dan rasul sejumlah lembaran/shahifah/صحيفة atau bentuk jamaknya shuhuf/ صحف atau lembaran-lembaran, sebagaimana lembaran yang telah diturunkan kepada Nabi Ibrahim dan Nabi Musa.

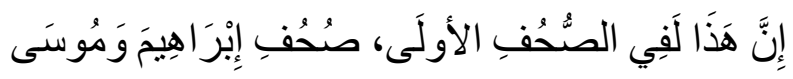

"Sesungguhnya ini benar-benar terdapat dalam Kitab-Kitab yang dahulu, (yaitu) Kitab-Kitab Ibrahim dan Musa." (Al-A'la : 18-19) 


\section{Jumlah, Nama-Nama Kitab Dan Sahifah}

Sedangkan jumlah kitab dan shahifah seluruhnya, jika dirujuk kehadith da'if riwayat Ibnu Hibban, berjumlah 100 shahifah dan 4 kitab:

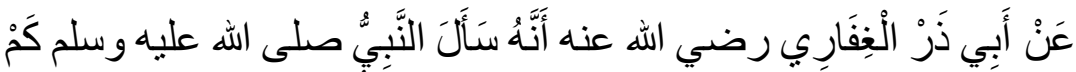

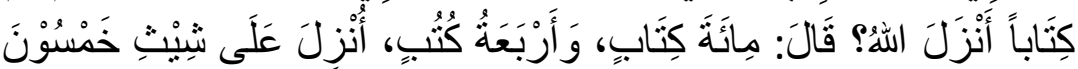

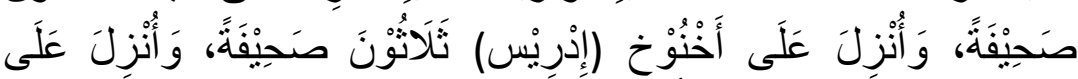

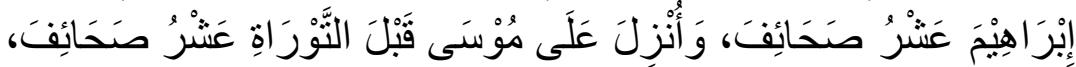

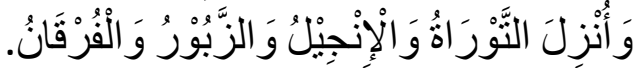

Dari Abu Dzarr Al-Ghifari Ra bertanya kepada Rasulullah Saw: "berapa Kitab yang Allah turunkan?" Rasulullah menjawab: "100 Kitab ditambah 4 Kitab, diturunkan kepada Syith 50 lembar, kepada Akhnukh/Idris 10 lembar, kepada Ibrahim 10 lembar, kepada Musa sebelum Taurat 10 lembar, dan diturunkan Taurat, Injil, Zabur, dan Al-Qur'an.

Namun hadits ini tidak bisa dijadikan sandaran karena lemah riwayatnya. Namun yang perlu diyakini adalah Allah menurunkan kitab-kitab kepada para nabi dan rasul. Diantara kitab yang diturunkan antara lain:

1. Taurat, diturunkan kepada Nabi Musa AS

$$
\text { وَلَقَذْ آتَنَنَا مُوسَى الْكِتَابَ وَجَعَلْنَا مَعَهُ أَخَاهُ هَارُونَ وَزِيرًا }
$$

"Dan Sesungguhnya Kami telah memberikan Al-Kitab (Taurat) kepada Musa dan Kami telah menjadikan Harun saudaranya, menyertai Dia sebagai wazir (pembantu)." (Al-Furqan: 35)

Al-Kitab di ayat ini dimaksudkan sebagai Taurat, di ayat yang lain disebutkan ketika Allah berbicara tentang kitab orang-orang Yahudi: 


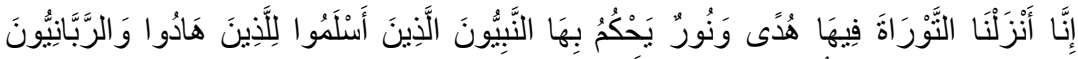

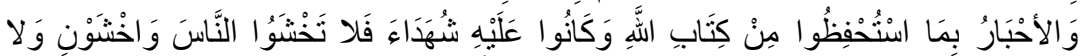

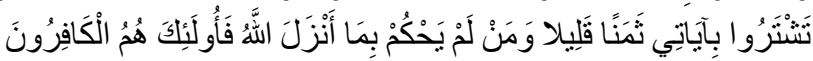

"Sesungguhnya Kami telah menurunkan kitab Taurat di dalamnya (ada) petunjuk dan cahaya (yang menerangi), yang dengan kitab itu diputuskan perkara orang-orang Yahudi oleh nabi-nabi yang menyerah diri kepada Allah, oleh orang-orang alim mereka dan pendeta-pendeta mereka, disebabkan mereka diperintahkan memelihara Kitab-Kitab Allah dan mereka menjadi saksi terhadapnya. karena itu janganlah kamu takut kepada manusia, (tetapi) takutlah kepada-Ku. dan janganlah kamu menukar ayat-ayat-Ku dengan harga yang sedikit. Barangsiapa yang tidak memutuskan menurut apa yang diturunkan Allah, Maka mereka itu adalah orang-orang yang kafir." (Al-Ma'idah: 43-44)

2. Zabur, diturunkan kepada Nabi Daud AS, sebagaimana firman Allah Swt:

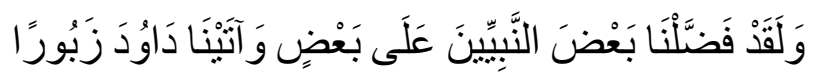

"Dan Sesungguhnya telah Kami lebihkan sebagian nabi-nabi itu atas sebagian (yang lain), dan Kami berikan Zabur kepada Daud." (Al-Isra': 55)

3. Injil, diturunkan kepada Nabi Isa AS, sebagaimana firman Allah Swt

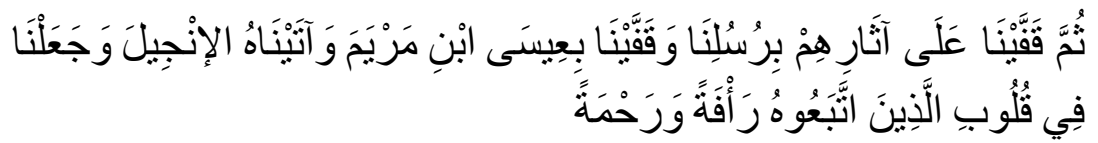

"kemudian Kami iringi di belakang mereka dengan rasul-rasul Kami dan Kami iringi (pula) dengan Isa putra Maryam; dan Kami berikan kepadanya Injil dan Kami jadikan dalam hati orang- orang yang mengikutinya rasa santun dan kasih sayang." (Al-Hadid 27)

4. Al-Qur'an kitab terakhir, diturunkan kepada Nabi Muhammad SAW 
Selain keempat kitab ini Allah juga menurunkan beberapa lembaran/shahifah kepada Nabi Ibrahim AS dan Nabi Musa AS (Al-A'la: 18-19), dan jika dirujuk kepada Hadith riwayat Abu Dzar, ada juga shahifah yang diturunkan kepada Nabi Syits dan Nabi Idris.

\section{Keistimewaan Al-Qur'an}

Al-Qur'an adalah kitab yang diturunkan Allah kepada nabi Muhammad SAW, ia adalah kitab terakhir yang memiliki keistimewaan dibandingkan kitab-kitab sebelumnya. Keistimewaan-keistimewaan itu, antara lain: $:^{120}$

1. Al-Qur'an adalah kitab yang dijaga oleh Allah Swt otentisitasnya (keasliannya) dan tidak ada satu penyimpangan sedikitpun di dalamnya. Allah berfirman:

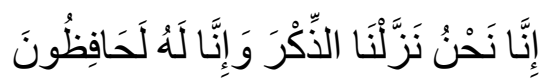

"Sesungguhnya Kami-lah yang menurunkan Al Quran, dan Sesungguhnya Kami benar-benar memeliharanya." (Al-Hijr: 9)

Sedangkan kitab-kitab yang lain telah tercampur baur antara yang benar-benar datang dari Allah dan yang merupakan karangan manusia. Mengenai hal ini Allah mengabarkan:

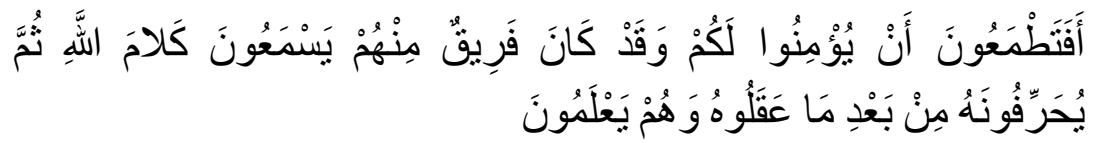

"Apakah kamu masih mengharapkan mereka akan percaya kepadamu, Padahal segolongan dari mereka mendengar firman Allah, lalu mereka mengubahnya setelah mereka memahaminya, sedang mereka mengetahui?" (Al-Baqarah: 75)

${ }^{120}$ Abu Bakar Al-Jaza'iri, 'Aqidatu I-Mu'Min (Kairo: Daaru I-Aqidah, 2004). $142-143$ 
2. Al-Qur'an membenarkan kitab-kitab sebelumnya, sekaligus juga merevisi hukum-hukum dalam kitab-kitab itu, Allah berfirman:

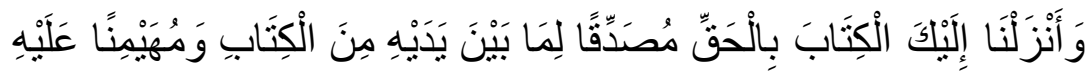

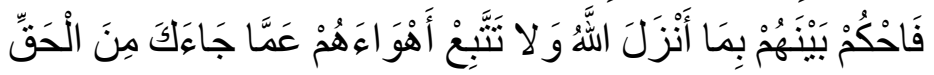

"Dan Kami telah turunkan kepadamu Al Quran dengan membawa kebenaran, membenarkan apa yang sebelumnya, Yaitu Kitab-Kitab (yang diturunkan sebelumnya) dan batu ujian terhadap Kitab-Kitab yang lain itu; Maka putuskanlah perkara mereka menurut apa yang Allah turunkan dan janganlah kamu mengikuti hawa nafsu mereka dengan meninggalkan kebenaran yang telah datang kepadamu." (Al-Ma'idah: 48)

3. Syari'at yang tercantum di dalam Al-Qur'an bersifat universal untuk seluruh manusia di muka Bumi hingga hari Akhir. Allah berfirman:

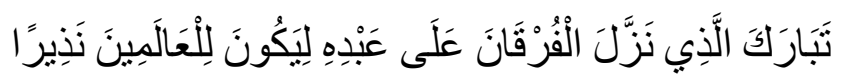

"Maha suci Allah yang telah menurunkan Al Furqaan (Al Quran) kepada hamba-Nya, agar Dia menjadi pemberi peringatan kepada seluruh alam." (Al-Furqan: 1)

\section{BERAKHLAQ KEPADA NABI MUHAMMAD SAW DAN AL-QUR'AN}

Mengikuti Nabi Muhammad Saw beserta Al-Qur'an merupakan bentuk mengimani semua nabi dan kitab dan suhuf. Karena ajaran Nabi Muhammad Saw yang ada dalam Al-Qur'an dan Al-Hadith merupakan perwujudan bagi seluruh ajaran para nabi dan rasul sejak masa Nabi Adam hingga Nabi Isa. Maka disini beberapa akhlaq yang harus ditanamkan dalam jiwa dan dilaksanakan dalam jiwa bagi seseorang yang percaya kepada seluruh nabi dan kitab-kitab Allah Swt.

\section{Cinta dan Mengagungkan Nabi Muhammad Saw}


Sudah menjadi tabi'at jika seseorang mencintai maka ia akan melakukan sesuatu yang membuat yang dicintai ridha kepadanya, atau jika ia benci terhadap sesuatu akan melakukan yang dibenci olehnya. Tentunya seseorang yang mencintai Allah harus melakukan apa yang diridahi Allah, dan mengetahui apa yang diridahi Allah tidaklah mungkin kecuali dengan apa yang diajarkan Nabi Muhammad Saw. Maka mencintai Allah harus mengikuti Nabi Muhammad Saw. Mengikuti Nabi Muhammad Saw harus mencintai Nabi Muhammad itu sendiri, karena seseorang tidak mungkin mengikuti sesuatu kecuali jika ia mencintainya. ${ }^{121}$ Allah Swt berfirman:

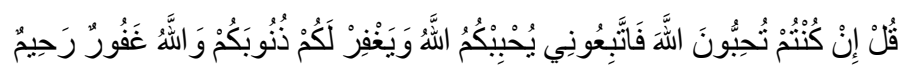

Katakanlah: "Jika kamu (benar-benar) mencintai Allah, ikutilah Aku, niscaya Allah mengasihi dan mengampuni dosa-dosamu." Allah Maha Pengampun lagi Maha Penyayang. (Ali Imran:31)

Kemudian cinta kepada Nabi Muhammad Saw tidak mungkin dilakukan kecuali dengan mengikuti para Sahabat Nabi, yakni kaum muslim yang bertemu dengan Nabi Muhammad Saw, karena mereka adalah orang yang pertama memperoleh pengajaran dari Nabi Saw(as-sabiquna l-awwalun). Membenci sahabat sebagaimana kaum Syi'ah yang mengkafirkan sahabat, merupakan suatu kekufuran tersendiri, karena periwayatan Al-Qur'an dan Hadith semuanya berasal dari para Sahabat Ra. ${ }^{122}$

Mencintai Nabi Muhammad Saw berarti harus mengaggungkannya, baik dalam fikiran, ucapan, dan perbuatan. Allah mengajarkan dalam Al-Qur'an tentang bagaimana

\footnotetext{
${ }^{121}$ Muhammad Khalifah Bin Ali At-Tamimi, Huququ N-Nabiy 'ala Ummatihi Fii Dau'i I-Kitab Wa s-Sunnah, 1st edn (Riyad: Adwa'u s-Salaf, 1997). P.284

${ }_{122}$ Abu Na'im Al-Ashbani, Ma'rifatu s-Shahabah, ed. by 'Adil bin Yusuf Al-'Azazi (Riyad: Daaru I-Watan lii n-Nashr). P.6
} 
bermu'amalah dengan Rasulullah, diantaranya adalah tidak boleh berbicara terlalu keras kepada Nabi (Al-Hujurat: 2), tidak boleh memanggil Nabi seperti panggilan kawan (An-Nur:63), harus memenuhi panggilan Rasulullah Saw (Al-Anfal:24), tidak boleh berfatwa sebelum Rasulullah (Al-Hujurat:1), tidak boleh memanggil dari belakang kamarnya (Al-Hujurat: 4-5), ketika Rasulullah berbicara tidak boleh meninggalkan majelis (An-Nur:62).

Sedangkan pada masa ini tidak mungkin bagi seseorang untuk bermu'amalah dengan Nabi, maka mengikuti perintah dan larangan, beserta tradisi-tradisinya merupakan bentuk cinta kepada Nabi Muhammad. Dalam sebuah riwayat hadith, suatu hari Rasulullah Saw berwudu dan para sahabat membasuh dengan bekas air wudhunya. Rasulullah kemudian bertanya "mengapa kalian melakukan ini?", para sahabat menjawab "cinta Allah dan Rasul-Nya", Rasulullah berkata "rahasianya (dalam mencintai Allah dan Rasul-Nya) adalah bahwa Allah Swt dan Rasul-Nya akan mencintainya atau jika ia mencintai Allah dan Rasul-Nya, maka agar ia mempercayai semua perkataan Rasul-Nya, dan melaksanakan amanah jika diberi amanah, dan memperbaiki hubungan dengan tetangga." ${ }^{123}$ Hadith ini menunjukkan bahwa untuk mencintai Nabi yang paling utama adalah mengikuti segala tabi'at, sunnah, perintah dan larangan, serta berakhlaqu I-karimah.

Mencintai Nabi Muhammad juga harus dilakukan melalui lisan dan kalbu, yaitu dengan cara bershalawat. Allah Swt memerintahkan untuk bershalawat kepada Nabi Muhammad Saw, sebagaimana Allah dan para malaikat juga bershalawat kepadanya:

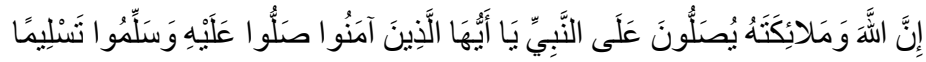

${ }^{123}$ Al-Bayhaqi. 3/110-111 
Sesungguhnya Allah dan malaikat-malaikat-Nya bershalawat untuk Nabi Hai orang-orang yang beriman, bershalawatlah kamu untuk Nabi dan ucapkanlah salam penghormatan kepadanya (Al-Ahzab:56)

Pada Ayat ini ditafsirkan oleh Sufyan At-Thauri dikutip darii Tafsir Ibnu Kathir, bahwa shalawatnya Allah adalah rahmat, dan shalawatnya malaikat adalah istighfar atau memohon ampunannya. Sedangkan shalawat sendiri adalah memberikan keberkahan atau kebaikan. Lafadz shalawat ada beberapa, diantaranya adalah yang dibaca ketika tashahud baik awal maupun akhir, sebagaimana dalam hadith:

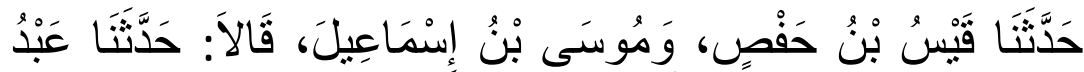

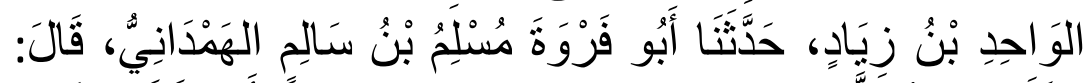

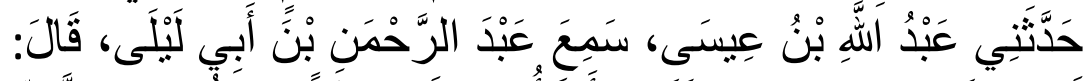

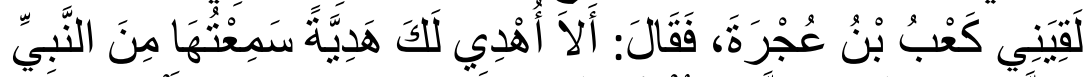

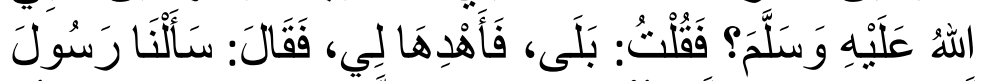

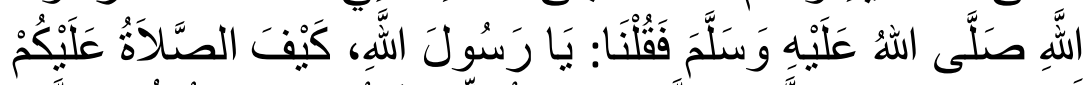

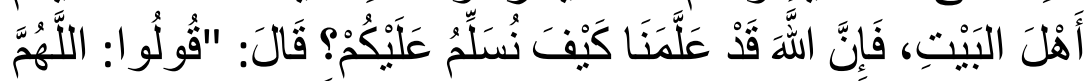

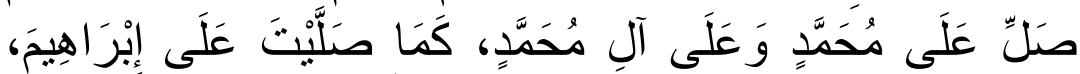

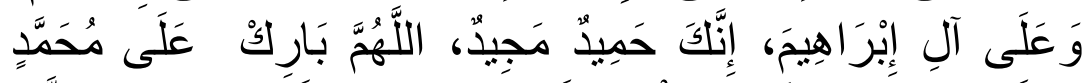

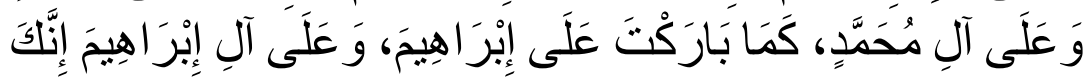

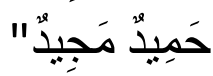

... Abdur Rahman bin Abi Layla berkata: aku bertemu dengan Ka'ab bin 'Ujrah, ia berkata: "ingatlah, aku memberimu hadiah yang aku dengar dari Rasulullah Saw?" aku berkata: "baiklah berikanlah kepadaku", maka ia berkata: "kami bertanya kepada Rasulullah Saw kami berkata: "wahai Rasulullah bagaimanaah kami bershalawat kepada kalian para ahli bayt, karena sesungguhnya Allah sudah 
mengajarkan kami bagaimana mengucapkan salam atas kalian", Nabi berkata: "katakanlah: Ya Allah berilah shalawat kepada Nabi Muhammad dan kepada keluarga Muhammad ....." 124

\section{Mengikuti Akhlaq dan Tradisi Nabi Muhammad Saw}

$$
\text { وَإِنَّكَ لَعَلى خُلُقِ عَظِيٍِ }
$$

Dan Sesungguhnya kamu benar-benar akhlaq yang agung. (Al-Qalam: 4)

Ayat ini mengajarkan bahwa Nabi Muhammad Saw memiliki akhlaq yang tertinggi. Tentunya akhlaq yang dicontohkan Nabi selama masa hidupnya tidak hanya dijadikan tontonan atau cerita belaka, namun ia harus menjadi contoh yang perlu dipelajari dan ditiru, karena kesempurnaan akhlaq telah ditunjukkan oleh Rasulullah Saw. Sehingga mempelajari dan menirunya adalah usaha manusia untuk mencapai kesempurnaan akhlaq itu sendiri.

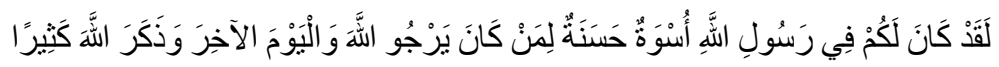

Sesungguhnya telah ada pada (diri) Rasulullah itu suri teladan yang baik bagimu (yaitu) bagi orang yang mengharap (rahmat) Allah dan (kedatangan) hari kiamat dan Dia banyak menyebut Allah. (Al-Ahzab: 21)

Manusia dapat mengetahui akhlaq-akhlaq yang baik berdasarkan Al-Qur'an, dan perwujudan yang sempurna dari akhlaq Al-Qur'an adalah Akhlaq Rasulullah Saw, sebagaimana pernyataan 'Aisyah Ra tatkala ditanya tentang akhlaq Rasulullah, ia menjawab:

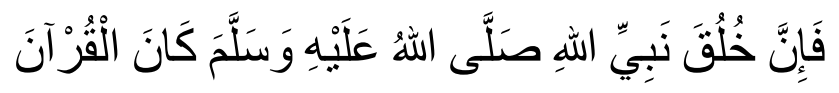

“Maka sesungguhnya akhlaq Nabi Saw adalah Al-Qur'an"125

Akhlaq Nabi yang lebih konkrit juga dapat dilihat melalui hadith-hadith yang menunjukkan sikap, watak, karakter Rasulullah

\footnotetext{
${ }^{124}$ Al-Bukhari. 6/146-147

${ }^{125}$ Muslim. 1/512
} 
Saw. Hadith-hadith itu sudah banyak dikumpulkan seperti yang dikumpulkan oleh Abu Dunya dalam beberapa tema, kumpulan Hadith yang terkenal Kitab Riyadu s-Salihin dsbg. dan wajib bagi seorang muslim untuk mempelajarinya dan mengamalkannya dalam kehidupan. Dengan demikian kehidupan Rasulullah dan seluruh watak, tabiat, dan akhlaqnya merupakan madrasah akhlaq yang mengajarkan tentang pemahaman akhlaq yang sempurna. ${ }^{126}$

Bagi seorang muslim mengikuti akhlaq Rasulullah adalah suatu kewajiban. Mengikuti akhlaq disini berarti taat untuk menjalankan semua perintah dan menjauhi larangannya. Dengan keyakinan bahwa apa yang diperintahkan Rasulullah adalah perintah Allah dan larangannya adalah larangan Allah, dan semua shari'atnya adalah shari'at Allah. Kemudian semua akhlaq, tingkah laku, karakter, perbuatan Rasulullah Saw adalah akhlaq yang diridahi oleh Allah. Maka seorang muslim pasti akan menentukan berbagai perkara dalam hidupnya dengan mengutamakan shari'at dan akhlaq Rasulullah ketimbang mengikuti hukum dan akhlaq yang ditentukan oleh akal manusia. ${ }^{127}$ Karena akal manusia terbatas dalam memahami kebaikan dan keburukan (sebagaimana yang telah dijelaskan dalam tahsin wa taqbih).

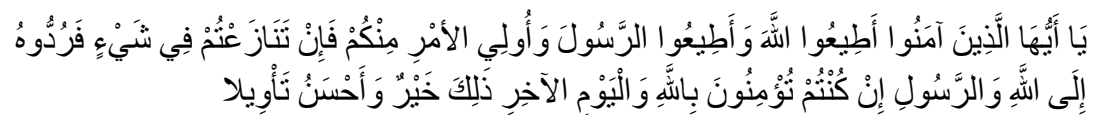

Hai orang-orang yang beriman, taatilah Allah dan taatilah Rasul (Nya), dan ulil amri di antara kamu. kemudian jika kamu berlainan Pendapat tentang sesuatu, Maka kembalikanlah ia kepada Allah dan Rasul, jika kamu benar-benar beriman kepada Allah dan hari kemudian. yang demikian itu lebih utama (bagimu) dan lebih baik akibatnya. (An-Nisa:59)

\section{Membaca dan Menghafal Al-Qur'an}

\footnotetext{
${ }^{126}$ Abdu r-Rahman Hasan Habankah Al-Maydani. P.435

${ }^{127}$ Al-Kharraz. 250
} 


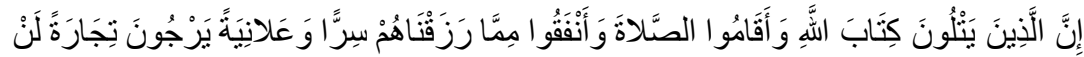
تَبْوزَ

Sesungguhnya orang-orang yang selalu membaca kitab Allah dan mendirikan shalat dan menafkahkan sebagian dari rezki yang Kami anugerahkan kepada mereka baik secara sembunyi-sembunyi atau terang-terangan, mereka itu mengharapkan perniagaan yang tidak akan merugi (Fathir: 29)

Ayat ini menunjukkan bahwa membaca Al-Qur'an merupakan suatu keutamaan bagi seorang muslim. Para sahabat dan tabi'in lebih suka membaca Al-Qur'an langsung kepada mushaf ketimbang membaca apa yang sudah mereka hafal. Hal ini dikarenakan apa yang mereka hafal bisa jadi memiliki kesalahan-kesalahan, sehingga mereka suka berlama-lama dalam membaca mushaf. Menurut Imam An-Nawawi membaca mushaf lebih utama daripada membaca dengan hafalan, karena melihat mushaf adalah ibadah yang diperintahkan. Dan dengan membaca seseorang di satu sisi membaca dan di sisi lain melihat tulisan di mushaf. ${ }^{128}$

Namun dengan membaca mushaf bukan berarti para sahabat dan tabi'in tidak suka menghafal Al-Qur'an, karena Rasulullah Saw memerintahkan umat muslim seluruhnya untuk menghafalkan Al-Qur'an walaupun hanya sebagian kecilnya:

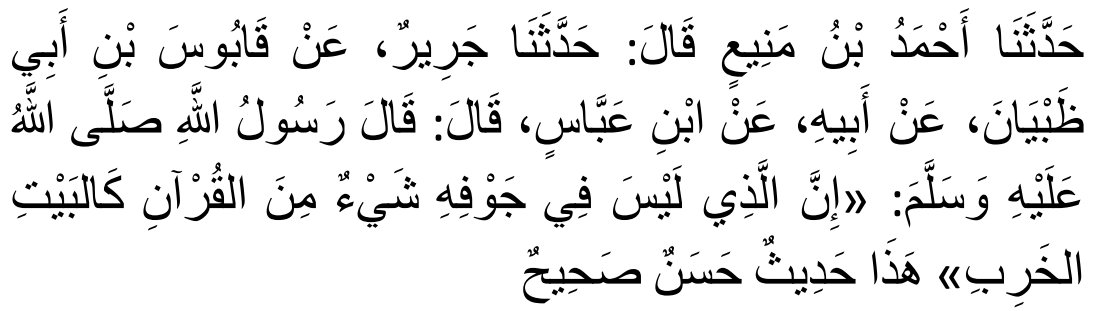

${ }^{128}$ Al-Kharraz. P. $155-156$ 
Rasulullah Saw bersabda: "sesungguhnya yang didalam dadanya tidak memiliki sesuatu dari Al-Qur'an, bagaikan rumah yang roboh."129

Seseorang yang membaca dan menghafal Al-Qur'an akan mendapatkan berkah atau kebaikan dari Allah Swt. Karena Al-Qur'an pada esensinya sudah mengandung kebaikan dan memberikan kebaikan bagi yang membacanya dan mengamalkannya. Al-Qur'an juga merupakan kalamu Ilah atau perkataan Allah, yang tentunya jauh lebih baik dari perkataan manusia, malaikat dan jin. Sehingga apa yang diiturunkan oleh Allah Swt kepada Nabi-Nya merupakan kebaikan tertinggi yang dapat membawa pembacanya menuju kebaikan di dunia dan di akhirat.

Dalam Al-Qur'an ada dua keberkahan: Pertama, keberkahan bagi para pembacanya, ketika seseorang membaca Al-Qur'an dan menggerakkan lidah dan kalbunya maka ia akan memperoleh kebaikan itu, dan akan nampak kebaikannya baik untuk tubuhnya maupun kalbunya. Hal ini karena Al-Quran adalah obat, baik obat untuk tubuh maupun untuk kalbu.

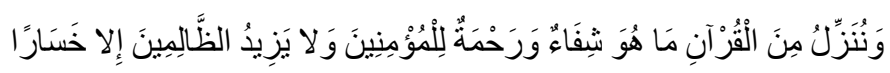

Dan Kami turunkan dari Al Quran suatu yang menjadi penawar dan rahmat bagi orang-orang yang beriman dan Al Quran itu tidaklah menambah kepada orang-orang yang zalim selain kerugian. (Al-Isra':82)

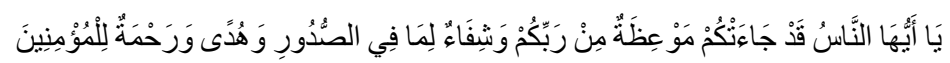

Hai manusia, Sesungguhnya telah datang kepadamu pelajaran dari Tuhanmu dan penyembuh bagi penyakit-penyakit (yang berada) dalam dada dan petunjuk serta rahmat bagi orang-orang yang beriman. (Yunus:57)

129 Al-Tirmidzi.5/177, Abu Zakariyya Yahya bin Sharifu d-Din As-Syafi'i An-Nawawi, At-Tibyan Fii Adab Hamlati l-Qur'an, ed. by Bashir Muhammad 'Uyun, 1st edn (Beirut: Maktabah Al-Mu'ayyad, 1991). P.17 
Kedua, keberkahan dalam mengamalkan Al-Qur'an, ketika seseorang mengimplementasikan berbagai akhlaq yang ada dalam Al-Qur'an, hal itu akan mensucikan jiwanya, karena Al-Qur'an sebagaimana yang telah disebutkan merupakan bentuk dari akhlaq tertinggi. ${ }^{130}$

\section{Mentadabburi Al-Qur'an}

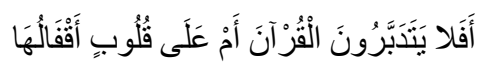

Maka Apakah mereka tidak memperhatikan Al Quran ataukah hati mereka terkunci? (Muhammad:24)

Tadabbur merupakan kumpulan dari perbuatan berfikir (tafakkur) dan meneliti berbagai sabab musababnya (ta'ammul). Bertadabbur dalam ayat tersebut berarti memikirkan, menghayati, mempelajari, mengkorelasikan, menyatukan antara ayat yang ada dalam teks dan ayat di alam semesta untuk mengingat Allah (dhikr), Allah Swt mendeskripsikan bagaimana seseorang bertadabbur:

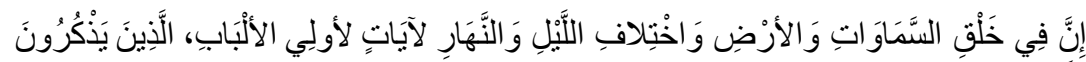

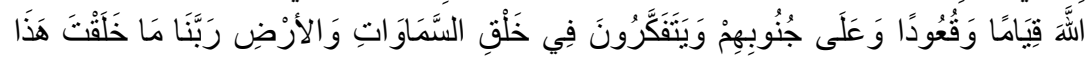
بَاطِلا سُبْحَانَكَ فَفِنَا عَذَابَ النَّارِ

Sesungguhnya dalam penciptaan langit dan bumi, dan silih bergantinya malam dan siang terdapat tanda-tanda bagi orang-orang yang berakal, (yaitu) orang-orang yang mengingat Allah sambil berdiri atau duduk atau dalam keadan berbaring dan mereka memikirkan tentang penciptaan langit dan bumi (seraya berkata): "Ya Tuhan Kami, Tiadalah Engkau menciptakan ini dengan sia-sia, Maha suci Engkau, Maka peliharalah Kami dari siksa neraka. (Ali Imran: 190-191)

Seseorang yang bertadabbur dengan Al-Qur'an untuk melihat pada luasnya alam semesta pasti akan melihat bahwa semua kejadian di alam semesta ini tidak mungin terjadi dengan sendirinya, pasti ada yang menciptakan. Pencipta itu pastilah yang maha kuasa, maha

${ }^{130}$ Muhammad Ad-Dabsy, Barakat Wa Anwaru L-Qur'an, 1st edn, 2016. P.11 
memiliki segala, yang menghidupkan dan mematikan, yang mengadakan dan meniadakan. Keyakinan ini harus menjadi awal mula dan tujuan semua proses keilmuan manusia, sehingga semakin berilmu seorang muslim akan semakin bertambah imannya dan semakin baik akhlaqnya.

Namun tidak semua manusia itu mampu mentadabburi Al-Qur'an karena tidak semua orang dibukakan kalbunya untuk menerima Al-Qur'an. Ibnu Qayim Al-Jauziyyah membagi manusia kedalam 3 karakteristik:

Pertama,manusia yang kalbunya mati, sehingga ayat Al-Qur'an tidak memiliki implikasi apapun dalam dirinya. Mereka inilah orang yang buta yang tidak melihat.

Kedua, manusia yang kalbunya hidup, siap untuk menerima kebenaran, namun ia belum mendengar ayat Al-Qur'an bisa jadi karena belum ada yang menyampaikan atau belum sampai kepadanya, sehingga kalbunya sibuk dengan urusan yang lain. Walaupun kalbunya siap menerima kebenaran, namun kalbunya masih mati. Mereka adalah orang yang mampu melihat, namun tidak melihat pada tempat yang benar, sehingga sama saja belum melihat.

Ketiga, manusia yang kalbunya hidup, siap untuk menerima kebenaran, dan ia mendengarkan Al-Qur'an dengan pendengarannya, dan menghadirkan Al-Qur'an dalam kalbunya, mereka meihat dengan matanya dan mengarahkan pandangan pada tujuan yang benar, sehingga mengambil manfaat dari Al-Qur'an. ${ }^{131}$

Seseorang yang beriman ketika mendengarkan ayat-ayat Al-Qur'an akan merasakan sesuatu yang berbeda dibandingkan dengan mendengarkan musik atau sesuatu yang lainnya. para

${ }^{131}$ Sa'id Abdu Al-'Adhim, Mafatihu L-Fahmi Wa t-Tadabburi I-Qur'an Wa Tahqiqu n-Najah Fii I-Hayah (Iskandariyyah: Daaru I-Iman, 2005). P.11-12 
Sahabat Ra sebagaimana yang diriwayatkan oleh Asma' binti Abu Bakar, ketika mendengarkan Al-Qur'an seolah-olah Allah menggambarkan kepada mereka, dan mereka menangis dan kulit mereka merinding. ${ }^{132}$ Inilah yang disebut dengan tingkatan Ihsan, yaitu "menyembah Allah seolah-olah melihat Allah dan jika Allah tidak melihat maka ia yang melihat Allah." Mereka adalah orang yag beriman dengan sebenar-benarnya iman, Allah menggambarkan tentang mereka:

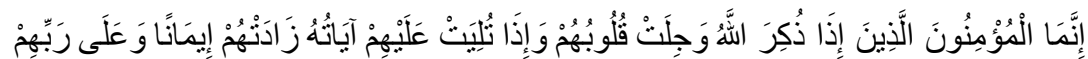
يَتَوَكَلُونَنَ

Sesungguhnya orang-orang yang beriman ialah mereka yang bila disebut nama Allah gemetarlah hati mereka, dan apabila dibacakan ayat-ayatNya bertambahlah iman mereka, dan hanya kepada Tuhanlah mereka bertawakkal. (Al-Anfal:2)

Al-Qur'an bukanlah kitab mantra yang hanya dibaca saja tanpa diketahui maknanya. la adalah petunjuk bagi seluruh umat manusia, sehingga menyingkap makna yang terkandung di dalamnya dan mengamalkan kandungannya akan memberikan manfaat yang luar biasa bagi kehidupan manusia baik secara individu maupun sosial. Para sahabat menangis ketika membaca Al-Qur'an, tidak lain karena keindahan makna, ibarat, dan kata-kata yang dirangkai dalam Al-Qur'an membuat mengharuskan bagi orang yang memahaminya untuk menangis.

Setiap orang akan memahami Al-Qur'an berbeda-beda tergantung pada corak keilmuan yang dimilikinya. Hal ini menunjukkan keluasan makna yang terkandung dalam Al-Qur'an, At-Tustari menyebutkan bahwa seandainya manusia diberi Al-Qur'an, maka seribu pemahaman belum mampu merepresentasikan apa yang Allah maksudkan dalam kitab-Nya. Karena Al-Qur'an adalah

${ }^{132}$ Al-Kharraz. P.185 
perkataan Allah (kalaamullah), dan perkataan-Nya adalah sifat-Nya. Jika Allah tidak memiliki batas, begitu pula dengan pemahaman terhadap perkataan-Nya yang juga tak terbatas, semuanya dipahami dengan ukuran yang Allah bukakan dalam kalbu tiap insan, dan perkataan Allah bukan makhluq sehingga tidak mungkin membatasi pemahaman kalamullah dengan pemahaman makhluq. ${ }^{133}$

Kita dapat mengambil ibrah dari kisah Maurice Bucaille (1920-1998) salah seorang dokter dari Perancis dan merupakan anggota dari "French Society of Egyptology" yang kemudian masuk Islam, dalam meneliti mayat salah satu Fir'aun menemukan sebuah bukti dari kebenaran ayat Al-Qur'an, dalam sebuah penelitian yang ia lakukan bersama beberapa ilmuan Egyptology (ahli ilmu Mesir kuno) menemukan mayat Fir'aun yang bernama Merneptah, anak dari Ramesses II, yang ia sebut sebagai Fir'aun yang mengejar Musa hingga ke Laut Merah. Awalnya tidak ada bukti bahwa Ramesses II itu mati dengan tenggelam, namun setelah dilakukan penelitian secara fisiologi di daerah perut, ditemukan bahwa mayat Ramesses II itu kemungkinan mati karena tenggelam atau karena adanya goncangan yang dahsyat, atau bisa juga mati karena keduanya. Dalam Bible perjanjian lama Exodus 14:28 disebutkan bahwa kereta tempur, tentara kuda, dan semua rombongan Fir'aun yang masuk kelaut mati di dalamnya dan tidak ada bekas sama sekali. la melihat hal ini berbeda dengan Al-Qur'an yang menunjukkan bahwa mayat Fir'aun itu diselamatkan tidak sirna:

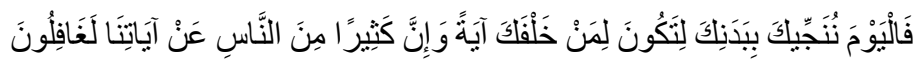

Maka pada hari ini Kami selamatkan badanmu (Fir'aun) supaya kamu dapat menjadi pelajaran bagi orang-orang yang datang sesudahmu dan

\footnotetext{
133 Al-'Adhim, Mafatihu L-Fahmi Wa t-Tadabburi I-Qur'an Wa Tahqiqu n-Najah Fii I-Hayah. P.22
} 
Sesungguhnya kebanyakan dari manusia lengah dari tanda-tanda kekuasaan kami.

Bukti ini sebelumnya belum pernah ditemukan, namun dengan adanya penemuan dan penelitian tersebut memberikan makna baru dari penafsiran dari ayat tersebut. Kemudian karyanya La Bible, le Coran, et la Science, sebuah karya fenomenal yang diterjemahkan dalam berbagai bahasa termasuk Bahasa Indonesia, dapat ditemukan berbagai macam tadabbur ilmiah Bucaille terhadap ayat-ayat Qur'an dengan mencari ketepatan dan korelasinya dengan bukti-bukti sains. ${ }^{134}$

${ }^{134}$ Maurice Bucaille, The Bible, The Qur'an and Science, ed. by Alastair D. Pannel and Maurice Bucaille (Lahore: Kazi Publications). P.237-241 


\section{BAB IV}

\section{AS-SAM'IYYAT}

Pada bab ini akan dijelaskan perkara-perkara yang termasuk as-sam'iyyat atau hal-hal yang tidak bisa dilihat dengan panca indera atau dengan penalaran akal, namun disebutkan di Al-Qur'an dan Al-Hadith, dan setiap orang muslim wajib untuk mengimaninya. Kemudian akan dibahas konsekwensi akhlaq ketika seorang muslim beriman kepada hal-hal yang as-sam'iyyyat.

Perkara As-Sam'iyyat yang akan dibahas antara lain: hari akhir dan makhluq-makhluq ghaib. Qada' dan qadar juga termasuk pada bab ini, namun karena cakupannya luas akan dibahas pada bab berikutnya.

\section{IMAN KEPADA HARI AKHIR ${ }^{135}$}

Setiap orang Muslim wajib beriman kepada hari akhir, yakni akan datang hari kehancuran alam semesta, kemudian manusia akan dibangkitkan untuk diadakan penghakiman amal baik dan buruk. Dan orang yang hanya meyakini Allah namun belum meyakini hari akhir maka belum bisa disebut Muslim. Allah berfirman:

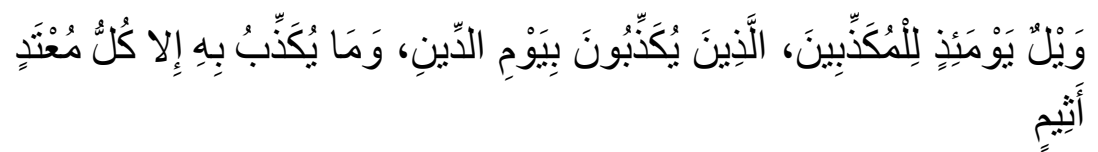

kecelakaan yang besarlah pada hari itu bagi orang-orang yang mendustakan, (yaitu) orang-orang yang mendustakan hari pembalasan. dan tidak ada yang mendustakan hari pembalasan itu

135 Al-Ashqari, Al-'Aqidah 'Ala Dau'i l-Kitab Wa Sunnah. Jilid 5 No.1 (Al-Qiyamah Al-Sughra), No.2 (Al-Qiyamah Al-Kubra), No.3 (Al-Jannah wa Al-Naar) 
melainkan setiap orang yang melampaui batas lagi berdosa. (Al-Muthaffifin : 10-12)

Maka mengimani hari akhir adalah bagian daripada keimanan, dan Allah telah mengkabarkannya di dalam Al-Qur'an, bahwa hari akhir itu pasti terjadi.

Hari Akhir ini memiliki banyak nama, antara lain:

1. Yaumu I-Qiyamah (يوم القيامة) Al-Qiyamah berasal dari kata قَامَ yang artinya berdiri, tegak, bangkit, bangun, maksudnya adalah hari dimana tegaknya janji Allah yang ada di dalam firman-Nya, atau juga bisa diartikan bangkitnya manusia dari kuburnya. Allah menyebutkan di 70 ayat, diantaranya :

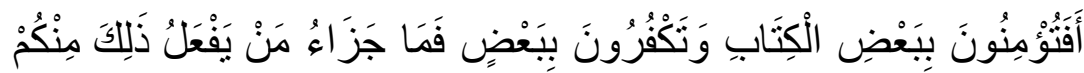

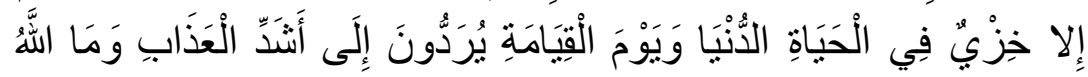

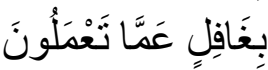

"Apakah kamu beriman kepada sebahagian Al kitab (Taurat) dan ingkar terhadap sebahagian yang lain? Tiadalah Balasan bagi orang yang berbuat demikian daripadamu, melainkan kenistaan dalam kehidupan dunia, dan pada hari kiamat mereka dikembalikan kepada siksa yang sangat berat. Allah tidak lengah dari apa yang kamu perbuat." (Al-Baqarah: 85)

2. Yaumu l-Akhir (بوم الآخر) atau hari akhir, terkadang juga disebut Daaru I-Akhirah (دار الآخرة) atau Rumah yang terakhir, disebut demikian karena tidak ada hari setelah hari ini. Allah berfirman :

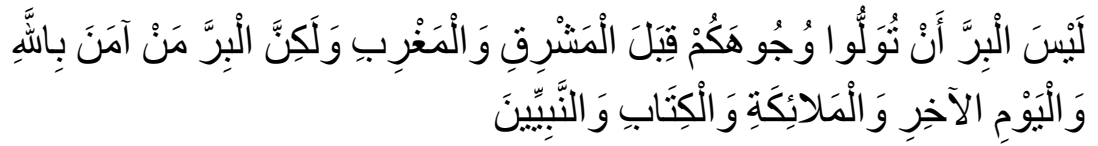


"Bukanlah kebajikan itu menghadapkan wajahmu ke arah timur dan barat, namun kebajikan itu ialah beriman kepada Allah, hari Kemudian, malaikat-malaikat, kitab-kitab, nabi-nabi. (Al-Baqarah: 177)

3. Al-Saa'ah (السياعة) artinya adalah waktu yang manusia ada disitu, atau dalam bahasa Arab juga sering diartikan dengan "jam". Hari akhir disebut Al-Saa'ah karena kejadian itu datang begitu saja, tidak diduga-duga dalam waktu yang sangat dekat. Allah berfirman:

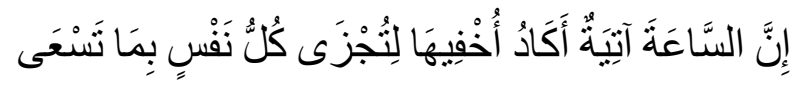

"Sesungguhnya hari kiamat itu akan datang aku merahasiakan (waktunya) agar supaya tiap-tiap diri itu dibalas dengan apa yang ia usahakan." (Thaha: 15)

4. Yaumu I-Ba'ts (يوم البعث: Al-Ba'ts menurut Ibnu Mandzur dalam Lisanu I-'Arab adalah Allah membangkitkan orang mati."

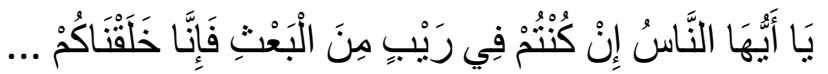

"Hai manusia, jika kamu dalam keraguan tentang kebangkitan (dari kubur), Maka (ketahuilah) Sesungguhnya Kami telah menjadikan kamu ....."(Al-Hajj: 5)

5. Yaumu I-Khuruj (يوم الخروج) atau hari keluar, maksudnya hari dikeluarkannya manusia dari kuburnya.

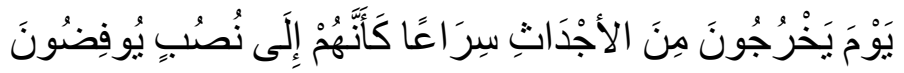

"(yaitu) pada hari mereka keluar dari kubur dengan cepat seakan-akan mereka pergi dengan segera kepada berhala-berhala (sewaktu di dunia)." (Al-Ma'arij: 43)

6. Al-Qari'ah (القار عَة) artinya mengetuk dan menggedor, menurut Imam Al-Qurtubi karena ia mengetuk hati manusia. Allah berfirman: 


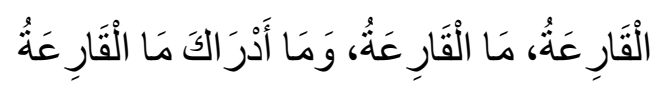

"Hari kiamat, apakah hari kiamat itu? Tahukah kamu Apakah hari kiamat itu?." (Al-Qari'ah: 1-3)

7. Yaumu I-Fasl (يوم الفصل) disebut demikian karena Allah memisahkan hambanya yang berselisih dan berseteru di hari akhir. Allah berfirman:

\section{إِنَّ يَوْمَ الْفَصْلِ كَانَ مِيقَاتًا}

"Sesungguhnya hari keputusan adalah suatu waktu yang ditetapkan." (An-Naba' : 17)

8. Yaumu d-Din (يوم الدين) artinya adalah hari pembalasan dan perhitungan. Allah berfirman:

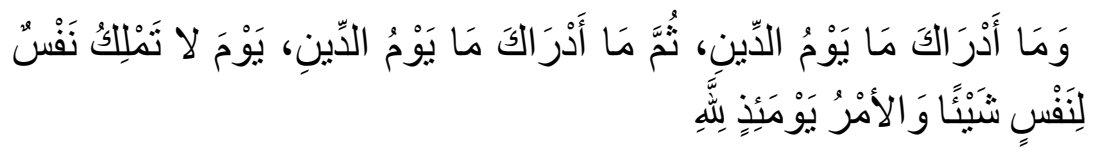

Tahukah kamu Apakah hari pembalasan itu? Sekali lagi, tahukah kamu Apakah hari pembalasan itu? (yaitu) hari (ketika) seseorang tidak berdaya sedikitpun untuk menolong orang lain. dan segala urusan pada hari itu dalam kekuasaan Allah. (Al-Infithar: 17-19)

9. Al-Shaakhah (الصاخة) adalah tiupan sangkakala pertama, Allah berfirman:

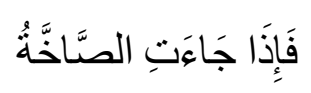

"Dan apabila datang suara yang memekakkan (tiupan sangkakala yang pertama)." ('Abasa: 33)

10. Al-Taammatu I-Kubra (الطامّة الكبرى) adalah tipan sangkakala kedua, Allah berfirman: 


\section{فَإِذَا جَاءَتِ الطَّامَّةُة الْكُبْرَى}

"Maka apabila malapetaka yang sangat besar (hari kiamat) telah datang." (An-Nazi'at: 34)

11. Yaumu I-Hasrah (يوم الحسرة) adalah hari kerugian, karena orang kafir rugi tidak beriman dan orang beriman rugi karena tidak menambah amal kebajikannya, Allah berfirman:

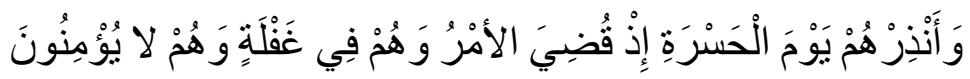

"Dan berilah mereka peringatan tentang hari penyesalan, (yaitu) ketika segala perkara telah diputus. dan mereka dalam kelalaian dan mereka tidak (pula) beriman." (Maryam: 39)

12. Al-Ghasiyah (الغاشثية) Artinya adalah hari yang menutupi, maksudnya di hari itu orang-orang kafir akan ditutupi oleh api neraka, Allah berfirman:

\section{هَلْْ أَتَالكَ حَدِيَثُ الْغَاثَيَيَةِ}

"Sudah datangkah kepadamu berita (Tentang) hari pembalasan?." (Al-Ghasyiyah: 1)

13. Yaumu I-Khulud (بوم الخلود) atau hari kekekalan, karena manusia pada hari itu akan kekal bertempat di akhirat, orang mu'min kekal di surga, orang kafir kekal di neraka, Allah berfirman:

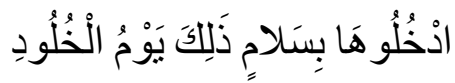

“Masukilah syurga itu dengan aman, Itulah hari kekekalan." (Qaf: 34)

14. Yaumu I-Hisab (يوم الحساب) atau hari perhitungan, dinamakan demikian karena akan dihitung amalan kebaikan dan keburukan manusia, Allah berfirman: 


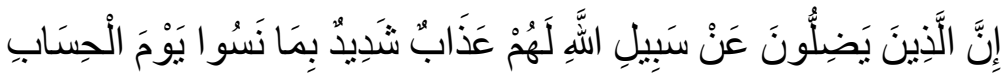

"Sesungguhnya orang-orang yang sesat dari jalan Allah akan mendapat azab yang berat, karena mereka melupakan hari perhitungan." (Shad : 26)

15. Al-Waqi'ah (الو اقعة) artinya kejadian, dinamakan demikian karena hari akhir pasti akan terjadi, Allah berfirman:

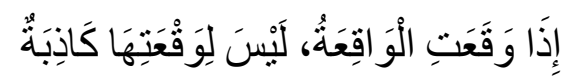

"Apabila terjadi hari kiamat, tidak seorangpun dapat berdusta tentang kejadiannya." (Al-Waqi'ah : 1-2)

16. Yaumu I-Wa'iid (يوم الو عبد) atau hari perjanjian, karena Allah akan menunaikan jannjinya pada hari itu, Allah berfirman:

$$
\text { وَنْفِخَ فِي الصُّورِ ذَلِلكَ يَوْمُ الْوَ عِيدِ }
$$

"Dan ditiuplah sangkakala. Itulah hari terlaksananya ancaman." (Qaf: 20)

17. Yaumu I-Azifati (بوم الآزفة) dinamakan demikian karena dekatnya hari ini, Allah berfirman:

$$
\text { أَزْفَتِ الآزِفَةُ، لَيْسَ لَهَا مِنْ دُونِ اللَّهِ كَاثِفَفْة }
$$

"Telah dekat terjadinya hari kiamat. Tidak ada yang akan menyatakan terjadinya hari itu selain Allah." (An-Najm 57-58)

18. Yaumu I-Jam'i (بوم الجمع) yakni hari dikumpulkannya manusia seluruhnya, Allah berfirman:

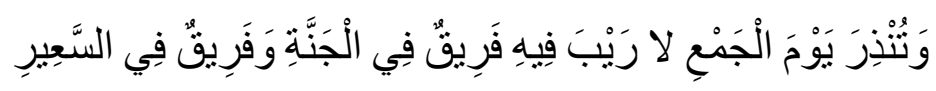

"serta memberi peringatan (pula) tentang hari berkumpul (kiamat) yang tidak ada keraguan padanya. segolongan masuk surga, dan segolongan masuk Jahannam." (As-Syura: 7) 
19. Al-Haaqqah (الحاقّة (الّة) artinya kejadian yang sebenarnya, dinamakan demikian karena akan dibuktikan kebenaran hari pembalasan, Allah berfirman:

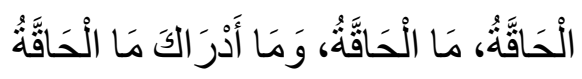

"Hari kiamat, Apakah hari kiamat itu?, dan tahukah kamu Apakah hari kiamat itu (Al-Haaqqah: 1-3)

20. Yaumu t-Talaaqi (بوم التلاق) atau hari bertemu, karena akan dipertemukan Nabi Adam As dengan seluruh anak cucunya, bertemunya orang yang dhalim dengan orang yang di dhalimi, dan juga manusia akan bertemu dengan perbuatan baik dan buruknya, Allah berfirman:

رَفِيعُ اللَّرَجَاتِ ذُو الْعَرْشِ يُلْقِي الرُّوحَ مِنْ أَمْرِهِ عَلَى مَنْ يَشَاءُ مِنْ عِبَادِهِ

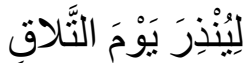

“ (Dialah) yang Maha Tinggi derajat-Nya, yang mempunyai 'Arsy, yang mengutus Jibril dengan (membawa) perintah-Nya kepada siapa yang dikehendaki-Nya di antara hamba-hamba-Nya, supaya Dia memperingatkan (manusia) tentang hari Pertemuan (hari kiamat)." (Al-Mu'min/Ghafir: 15)

21. Yaumu t-Tanaadi (يوم التنتاد) yaitu hari pemanggilan karena manusia akan dipanggil namanya satu persatu untuk mempertanggung jawabkan amalannya, Allah berfirman:

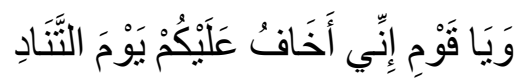

"Hai kaumku, Sesungguhnya aku khawatir terhadapmu akan siksaan hari panggil-memanggil." (Al-Mu'min: 32)

22. Yaumu t-Thaghabun (يوم التغابن) yaitu hari dinampakkannya kesalahan-kesalahan manusia, Allah berfirman: 


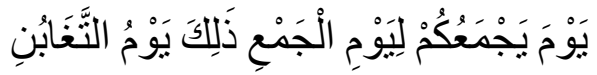

"(ingatlah) hari (dimana) Allah mengumpulkan kamu pada hari pengumpulan, Itulah hari dinampakkan kesalahan-kesalahan." (At-Taghabun: 9)

\section{Tanda-Tanda Hari Akhir}

Tanda-tanda hari akhir dibagi menjadi 3 tanda, ada tanda yang sudah terjadi, ada tanda yang belum terjadi, dan ada tanda-tanda besar. Diantara tanda yang telah terjadi antara lain:

a. Terjadi penaklukan terhadap negara Persia dan Romawi oleh umat muslim.

b. Banyak orang-orang yang mengaku nabi palsu mereka disebut sebagai Ad-Dajjaluun (الدجّالون).

c. Turun bala' dan fitnah (bencana) yang menimpa kaum muslim.

d. Terjadi pemberian titah atau kekuasaan kepada orang yang bukan pakarnya.

e. Rusaknya keadaan kaum muslim.

f. Ibu-ibu melahirkan tuannya, dan penggembala yang telanjang (maksudnya orang miskin) membangun gedung yang tinggi (HR.Muslim).

g. Seluruh orang kafir akan mengeroyok orang muslim sebagaimana makanan di nampan.

h. Terjadi saling menfitnah, menjatuhkan, memutarbalikkan fakta, karena telah terjadi praktek dosa yang dilakukan secara terang-terangan dan diambil pembenaran terhadapnya, seperti: minum khamr, perzinahan, lesbian-homo sex, dan ada derajat membenarkan kesalahan. 
i. Banyaknya harta, hingga tidak ada lagi orang yang perlu diberi zakat.

j. Orang hanya mau bersalaman kepada orang-orang tertentu,

k. Menyebarnya perdagangan, hingga sang istri turut membantu suaminya,

I. Munculnya pemutusan tali persaudaraan,

m. Terjadi banyak kesaksian palsu.

n. Rusaknya ukuran nilai-nilai, perkataan-perkataan dusta diterima dan dibenarkan, perkataan yang benar ditolak, pengkhianat diberi amanah, sehingga amanah itu dikhianati.

o. Polisi-polisi yang memegang cambuk (kekuasaan) dan mencambuk manusia.

\section{Adapun tanda-tanda yang belum terjadi antara lain:}

a. Jazirah Arab berubah menjadi kebun-kebun dan sungai-sungai sebagaimana asalnya demikian.

b. Nampaknya hilal menggelembung dan membesar.

c. Manusia bisa mengetahui bahasa hewan dan benda-benda mati dapat berbicara.

d. Sungai Efurat akan terpecah dan muncul darinya gunung emas.

e. Bumi mengeluarkan peti-petinya yang tersembunyi.

f. Ada suatu masa dimana kaum muslimin akan banyak sekali musuhnya sehingga ia terpojokkan hingga kota Madinah.

g. Akan ada seorang otoriter dari bani Qahtan yang menggiring manusia dengan tongkatnya, bisa ditakwilkan dengan kekuatannya. 
h. Terjadi fitnah yang besar.

i. Turunnya Imam Mahdi RA.

\section{Adapun tanda-tanda yang besar antara lain:}

a. Akan muncul asap/kabut (الأُخَانْ) yang akan membunuh orang-orang kafir, dan orang mu'min hanya akan merasakan keluarnya air dari hidungnya.

b. Akan muncul fitnah terbesar yakni Al-Masih Dajjal dinamakan "Al-Masih" karena matanya satu terhapus, ada juga yang mengatakan Al-Masih karena dia menutupi kebenaran dan menampakkan kebatilan. Ini berbeda dengan Al-Masih 'Isa bin Maryam, disebut "Al-Masih" karena ia menghapus penyakit orang yang sakit.

c. Turunnya Nabi Isa As kemuka bumi dan akan menetap hingga wafat.

d. Keluarnya Ya'juj dan Ma'juj

e. Kemudian agama Islam akan menyebar, kemudian Al-Qur'an akan diangkat dan kebaikan akan musnah.

f. Setelah itu manusia akan kembali kepada kejahiliyahan dan kembali menyembah berhala.

g. Kemudian Ka'bah akan dihancurkan.

h. Keluarnya hewan melata (الدابة).

i. Munculnya matahari dari barat.

j. Keluarnya api yang akan mengumpulkan manusia. 


\section{Sangkakala (الصُوْرُ)}

/القََْْنُ (الصُوْر sangkakala secara etimologi berarti tanduk mengenai hal ini Rasulullah Saw bersabda:

\section{الصسُّْرُ قَرْنْ بُنْفَخْ فِيْهِه}

Sangkakala adalah tanduk yang ditiupkan dengannya.

Sangkakala ini akan ditiup oleh Malaikat Izrafil AS, dan tiupan ini akan menghasilkan suara yang besar serta menjadi pertanda dari terjadinya hari akhir.

Sangkakala ini akan ditiupkan beberapa kali sebagai pertanda dari kehancuran dan kebangkitan manusia dari kuburnya. Namun para ulama' berbeda pendapat tentang jumlah ditiupnya sangkakala. Namun pendapat yang terkuat adalah 2 kali ditiupkannya sangkakala. Di dalam Al-Qur'an Allah menyebutkan tiupan yang pertama dengan ar-rajifah, dan yang kedua dengan ar-radifah.

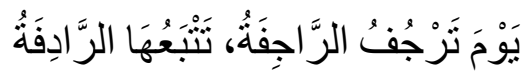

"(Sesungguhnya kamu akan dibangkitkan) pada hari ketika tiupan pertama menggoncang alam, tiupan pertama itu diiringi oleh tiupan kedua." (An-Nazi'at: 6-7)

Ada juga di surah Yasin 49-51 Allah menyebutkan bahwa tiupan yang pertama adalah "as-shayhah" yang kedua adalah "an-nafkh" atau tiupan.

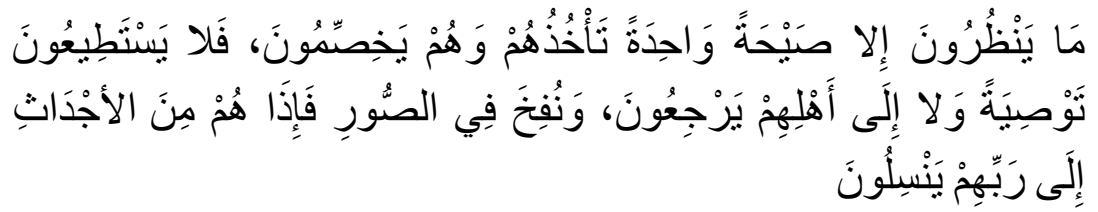


Mereka tidak menunggu melainkan satu teriakan saja (tiupan yang pertama) yang akan membinasakan mereka ketika mereka sedang bertengkar. Lalu mereka tidak Kuasa membuat suatu wasiatpun dan tidak (pula) dapat kembali kepada keluarganya. Dan ditiuplah sangkalala (tiupan yang kedua) Maka tiba-tiba mereka keluar dengan segera dari kuburnya (menuju) kepada Tuhan mereka. (Yasin: 49-51)

Melalui ayat ini dapat dilihat bahwa tiupan yang pertama adalah kehancuran dan kematian seluruh makhluk, dan di tiupan yang kedua adalah kebangkitan dari makhluk-makhluk untuk mempertanggung jawabkan semua amal perbuatannya.

Pendapat lainnya mengatakan bahwa tiupan sangkakala berjumlah 3 kali, pertama: untuk menunjukkan ketakutan, kedua: teriakan untuk kematian, ketiga: kebangkitan. Pendapat ini berdasarkan beberapa hadith yang diriwayatkan oleh Imam Al-Tabari, dan pendapat ini diikuti oleh Ibnu I-'Arabi, Ibnu Taymiyyah, Ibnu Kathir

Ibnu Hazm Al-Andalusi mengatakan terjadinya tiupan itu 4 kali, pertama: kematian, kedua: kematian, ketiga: teriakan dan ketakutan, manusia berhamburan seperti kapas yang terbang, namun tidak mati, keempat: proses berhamburan itu. Pendapat Ibnu Hazm ini tidak memiliki alasan yang kuat, dan tidak dapat dibenarkan karena tidak memiliki dalil.

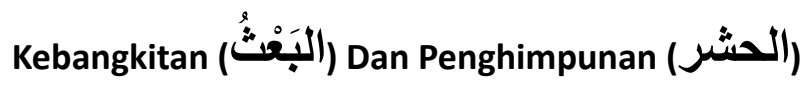

Kebangkitan adalah hari dihidupkannya manusia dari kematiannya. Kebangkitan itu mungkin terjadi dan pasti terjadi. Mengenai hal ini Allah berargumentasi, bahwa jika Allah SWT berkuasa untuk menciptakan manusia dari ketiadaan, tentu menjadi perkara yang mudah untuk menciptakan sesuatu yang sudah pernah diciptakan sebelumnya. Allah berfirman: 


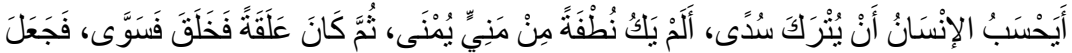

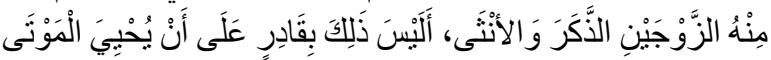

"Apakah manusia mengira, bahwa ia akan dibiarkan begitu saja (tanpa pertanggung jawaban)? Bukankah Dia dahulu setetes mani yang ditumpahkan (ke dalam rahim), Kemudian mani itu menjadi segumpal darah, lalu Allah menciptakannya, dan menyempurnakannya, lalu Allah menjadikan daripadanya sepasang: laki-laki dan perempuan. Bukankah (Allah yang berbuat) demikian berkuasa (pula) menghidupkan orang mati?". (Al-Qiyamah: 36-40)

Setelah ditiupnya sangkakala kedua maka manusia akan dibangkitkan dari kuburnya. Mengenai hal ini Allah menceritakan tentang keadaan manusia yang dibangkitkan pada hari itu:

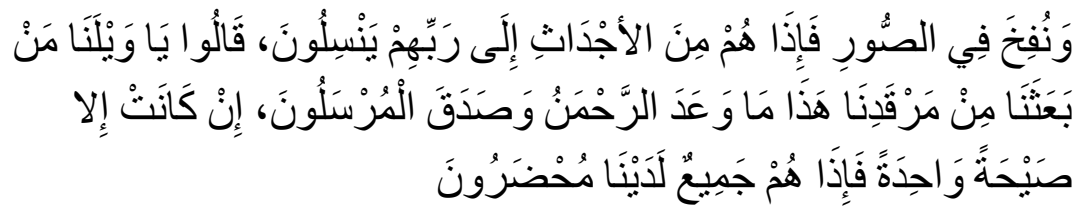

Dan ditiuplah sangkalala, Maka tiba-tiba mereka keluar dengan segera dari kuburnya (menuju) kepada Tuhan mereka. Mereka berkata: "Aduhai celakalah kami! siapakah yang membangkitkan Kami dari tempat-tidur Kami (kubur)?". Inilah yang dijanjikan (tuhan) yang Maha Pemurah dan benarlah Rasul- rasul(Nya). Tidak adalah teriakan itu selain sekali teriakan saja, Maka tiba- tiba mereka semua dikumpulkan kepada kami. (Yasin: 51-53)

Setelah manusia dibangkitkan maka mereka akan dikumpulkan di Mahsyar yakni tempat berkumpulnya seluruh manusia dari zaman nabi Adam As hingga akhir zaman menanti untuk dihitung amal perbuatannya, Rasulullah Saw bersabda:

$$
\text { "إِنَكُمْ لَمَحْشُرُوْنَ حُفَاةً عُرَاةً غُرْلاًا" }
$$

"Sesungguhnya kalian akan dikumpulkan telanjang kaki, telanjang badan, dan dalam keadaan umur masih muda." 
Mengenai hal ini Allah juga berfirman di banyak tempat di Al-Qur'an mengenai peristiwa ini, diantaranya:

$$
\text { قُلْ إِنَّ الأوَلِينَ وَالآخِرِينَ، لَمَجْمُو عُونَ إِلَى مِيقَاتِ يَوْمِ مَعْلُومِ }
$$

"Katakanlah: "Sesungguhnya orang-orang yang terdahulu dan orang-orang yang terkemudian, benar-benar akan dikumpulkan di waktu tertentu pada hari yang dikenal." (Al-Waqi'ah : $49-50$ )

\section{Penghitungan (الحسباب) Dan Timbangan (الميز ان)}

Al-Hisab atau perhitungan adalah ketika Allah Swt menampakkan kepada manusia tentang perbuatannya dan perkataannya, dan keadaan dirinya di dunia dan di akhirat apakah ia mu'min ataukah kafir, apakah ia taat ataukah bermaksiat. Allah berfirman:

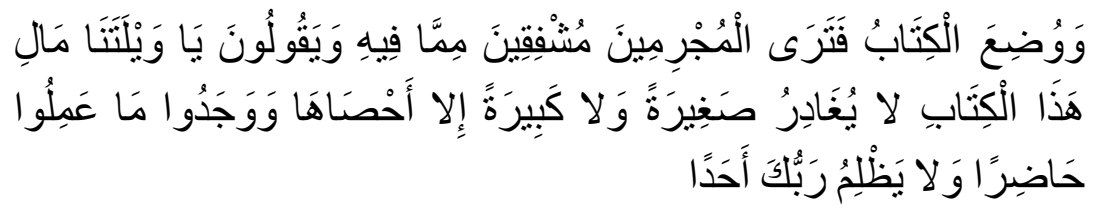

"Dan diletakkanlah Kitab, lalu kamu akan melihat orang-orang bersalah ketakutan terhadap apa yang (tertulis) di dalamnya, dan mereka berkata: "Aduhai celaka Kami, kitab Apakah ini yang tidak meninggalkan yang kecil dan tidak (pula) yang besar, melainkan ia mencatat semuanya; dan mereka dapati apa yang telah mereka kerjakan ada (tertulis). dan Tuhanmu tidak Menganiaya seorang juapun". (Al-Kahfi: 49)

Seluruh amal manusia akan dihitung dengan timbangan/al-mizan. Mengenai hal ini Allah berfirman:

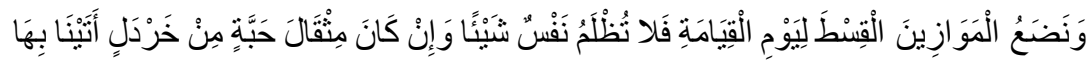

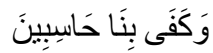

"Kami akan memasang timbangan yang tepat pada hari kiamat, Maka Tiadalah dirugikan seseorang barang sedikitpun. dan jika (amalan itu) hanya 
seberat biji sawipun pasti Kami mendatangkan (pahala)nya dan cukuplah Kami sebagai perhitungan." (Al-Anbiya': 47)

\section{Sirat (الصر (ط)}

Sirat secara etimologi adalah jalan, secara terminologi adalah jembatan berbentuk lengkung yang terbentang dipermukaan neraka jahannam yang akan dilewati oleh seluruh orang mu'min sejak zaman Nabi Adam hingga hari akhir. Sedangkan orang kafir tidak akan melewati sirat ini karena setelah terjadi hisab orang-orang kafir akan dikumpulkan semuanya dan digiring keneraka bersama-sama dengan tuhan-tuhan mereka, Allah Swt berfirman:

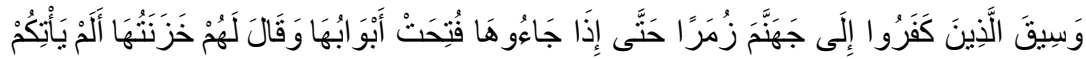

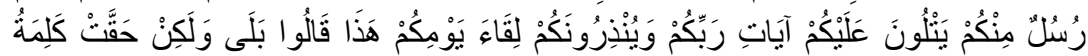

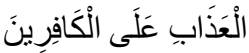

“Orang-orang kafir dibawa ke neraka Jahannam berombong-rombongan. sehingga apabila mereka sampai ke neraka itu dibukakanlah pintu-pintunya dan berkatalah kepada mereka penjaga-penjaganya: "Apakah belum pernah datang kepadamu Rasul-rasul di antaramu yang membacakan kepadamu ayat-ayat Tuhanmu dan memperingatkan kepadamu akan Pertemuan dengan hari ini?" mereka menjawab: "Benar (telah datang)". tetapi telah pasti Berlaku ketetapan azab terhadap orang-orang yang kafir." (Az-Zumar: 71)

Sirat ini lebih tajam dari pedang dan lebih tipis dari rambut disampingnya terdapat besi pengait yang akan menyambar manusia sesuai dengan perintah Allah. Orang mu'min akan berjalan diatasnya menuju ke surga ada yang secepat kilat, seperti angin, dan lambat bahkan dengan merangkak, semuanya tergantung dengan amal perbuatan masing-masing individu. Mengenai sirat ini ada di dalam banyak hadith Rasulullah Saw, diantaranya : 


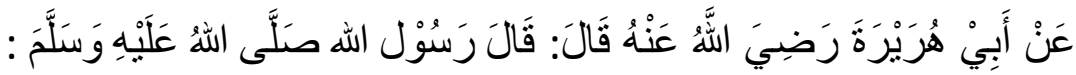

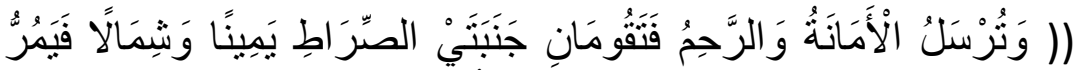

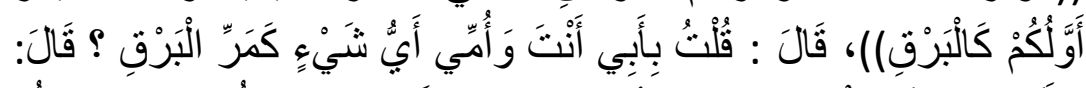

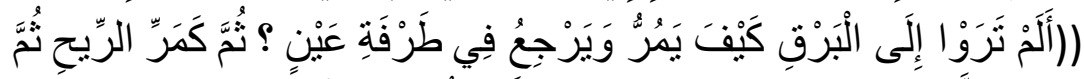

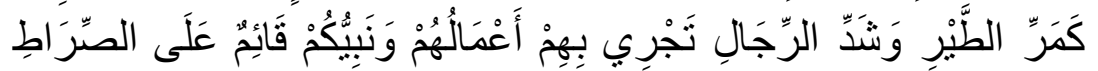

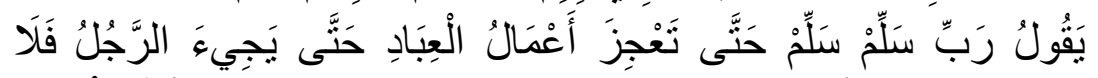

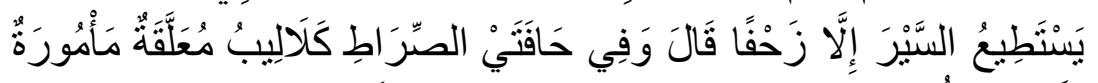

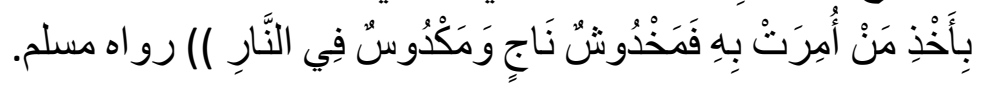

Dari Abu Hurairah Radhiyallahu anhu, ia berkata: Rasûlullâh Shallallahu 'alaihi wa sallam telah bersabda: "Lalu diutuslah amanah dan rohim (tali persaudaraan) keduanya berdiri di samping kair-kanan shiraath tersebut. Orang yang pertama lewat seperti kilat". Aku bertanya: "Dengan bapak dan ibuku (aku korbankan) demi engkau. Adakah sesuatu seperti kilat?" Rasul Shallallahu 'alaihi wa sallam menjawab : "Tidakkah kalian pernah melihat kilat bagaimana ia lewat dalam sekejap mata? Kemudian ada yang melewatinya seperti angin, kemudian seperti burung dan seperti kuda yang berlari kencang. Mereka berjalan sesuai dengan amalan mereka. Nabi kalian waktu itu berdiri di atas shirâth sambil berkata: "Ya Allâh selamatkanlah! selamatkanlah! Sampai para hamba yang lemah amalannya, sehingga datang seseorang lalu ia tidak bisa melewati kecuali dengan merangkak". Beliau menuturkan (lagi): "Di kedua belah pinggir shirâth terdapat besi pengait yang bergatungan untuk menyambar siapa saja yang diperintahkan untuk disambar. Maka ada yang terpeleset namun selamat dan ada pula yang terjungkir ke dalam neraka". ${ }^{136}$

Surga dan Neraka (الجنّة و الثّار)

${ }^{136}$ Muslim. 
Di dalam Al-Qur'an, Allah Swt sering menjelaskan bahwa nanti di hari akhir orang mu'min akan masuk surga dan orang kafir akan masuk neraka.

Surga adalah tempat yang Allah siapkan untuk para wali-Nya dan orang yang taat kepada-Nya, surga merupakan kenikmatan yang sempurna, tidak memiliki kekurangan, kabar-kabar yang bisa diterima dari Al-Qur'an dan Al-Hadith tentang surga semuanya membingungkan dan mengejutkan akal, karena akal tidak mampu untuk menggambarkan keagungan surga dan kesempurnaannya. Banyak sekali ayat yang menerangkan tentang keindahan Surga diantaranya :

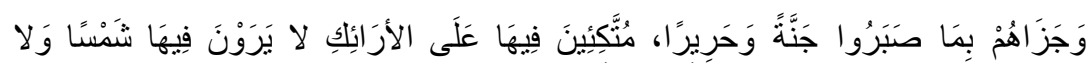

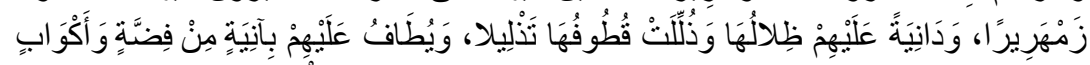

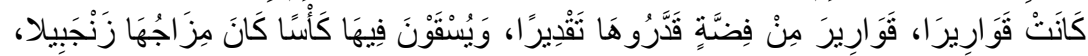

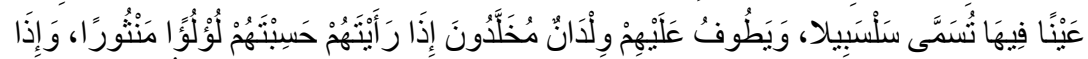

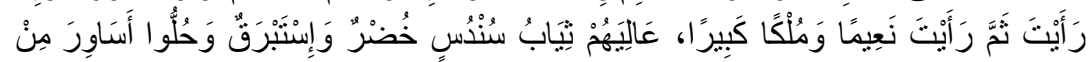

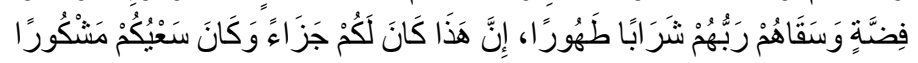

"Dan Dia memberi Balasan kepada mereka karena kesabaran mereka (dengan) surga dan (pakaian) sutera, di dalamnya mereka duduk bertelakan di atas dipan, mereka tidak merasakan di dalamnya (teriknya) matahari dan tidak pula dingin yang bersangatan. Dan naungan (pohon-pohon surga itu) dekat di atas mereka dan buahnya dimudahkan memetiknya semudah-mudahnya. Dan Diedarkan kepada mereka bejana-bejana dari perak dan piala-piala yang bening laksana kaca, (yaitu) kaca-kaca (yang terbuat) dari perak yang telah diukur mereka dengan sebaik-baiknya. Di dalam syurga itu mereka diberi minum segelas (minuman) yang campurannya adalah jahe. (yang didatangkan dari) sebuah mata air surga yang dinamakan salsabil. Dan mereka dikelilingi oleh pelayan-pelayan muda yang tetap muda. apabila kamu melihat mereka, kamu akan mengira mereka, mutiara yang bertaburan. Dan apabila kamu melihat di sana (surga), niscaya kamu akan melihat berbagai macam kenikmatan dan kerajaan yang besar. Mereka memakai pakaian sutera Halus yang hijau dan 
sutera tebal dan dipakaikan kepada mereka gelang terbuat dari perak, dan Tuhan memberikan kepada mereka minuman yang bersih. Sesungguhnya ini adalah Balasan untukmu, dan usahamu adalah disyukuri (diberi balasan)." (Al-Insan: 12-22)

Neraka adalah tempat yang Allah siapkan untuk orang-orang kafir yang menolak syari'at-Nya, dan para pendusta para rasul-Nya, neraka adalah tempat siksaan yang telah Allah siapkan untuk para musuh-musuh-Nya, dan penjara bagi para pendosa. Al-Qur'an banyak sekali menjelaskan pedihnya siksaan api neraka, bahkan Allah menggambarkan bahwa api neraka itu bahan bakarnya adalah manusia dan bebatuan, tempatnya dijaga oleh malaikat-malaikat yang terlihat menyeramkan.

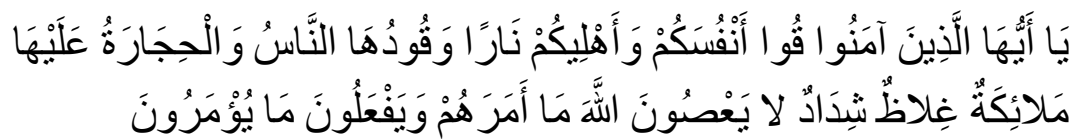

"Hai orang-orang yang beriman, peliharalah dirimu dan keluargamu dari api neraka yang bahan bakarnya adalah manusia dan batu; penjaganya malaikat-malaikat yang kasar, keras, dan tidak mendurhakai Allah terhadap apa yang diperintahkan-Nya kepada mereka dan selalu mengerjakan apa yang diperintahkan." (At-Tahrim: 6)

\section{MAKHLUK-MAKHLUK GHA'IB}

\section{Malaikat $^{137}$}

Iman kepada para malaikat merupakan salah satu rukun iman yang ke-dua, setiap muslim harus meyakini bahwa malaikat itu ada. Manusia tidak akan dapat mengetahui tentang wujud malaikat kecuali melalui dari apa yang telah dikabarkan oleh Allah dalam Al-Qur'an dan pemberitaan melalui Al-Hadith. Allah Swt berfirman:

\footnotetext{
137 Al-Ashqari, Al-'Aqidah 'Ala Dau'i I-Kitab Wa Sunnah. Jilid 2 ('Alamu I-Malaikati Al-Abrar)
} 


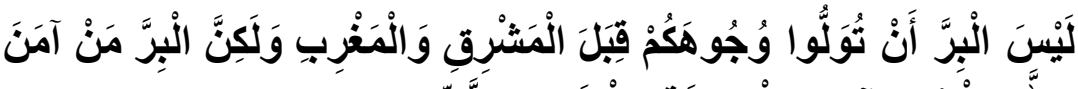

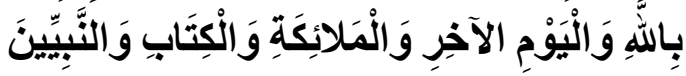

"Bukanlah menghadapkan wajahmu ke arah timur dan barat itu suatu kebajikan, akan tetapi Sesungguhnya kebajikan itu ialah beriman kepada Allah, hari Kemudian, malaikat-malaikat, kitab-kitab dan nabi-nabi.... ."(Al-Baqarah: 177)

Siapa itu malaikat? Abu Bakar Al-Jazairi mendefinisikan malaikat sebagai berikut: ${ }^{138}$

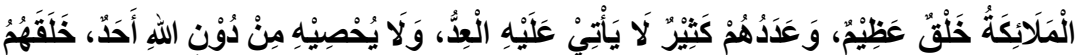

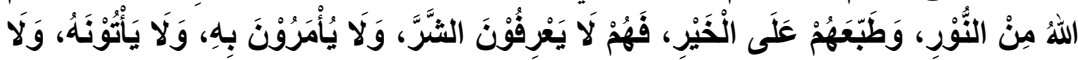

"Malaikat adalah ciptaan yang agung, jumlahnya banyak dan tidak dapat dihitung, tidak ada yang mampu menghitungnya kecuali Allah Swt. Allah menciptakannya dari cahaya dan memberikan mereka tabi'at dan watak yang baik, mereka tidak mengetahui keburukan, dan Allah tidak memerintahkannya untuk itu, dan mereka tidak mendatangi dan melakukan keburukan."

\section{Diciptakannya Malaikat}

Malaikat diciptakan sebelum Nabi Adam As, sebagaimana yang dikisahkan di Surah Al-Baqarah : 30

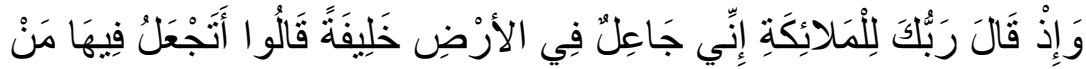

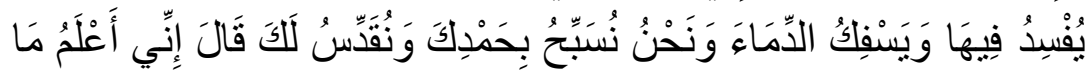
لا تَعْلَكْونَ

"Ingatlah ketika Tuhanmu berfirman kepada Para Malaikat: "Sesungguhnya aku hendak menjadikan seorang khalifah di muka bumi." mereka berkata: "Mengapa Engkau hendak menjadikan (khalifah) di bumi itu orang yang

${ }^{138}$ Al-Jaza'iri. 
akan membuat kerusakan padanya dan menumpahkan darah, Padahal Kami Senantiasa bertasbih dengan memuji Engkau dan mensucikan Engkau?" Tuhan berfirman: "Sesungguhnya aku mengetahui apa yang tidak kamu ketahui." (Al-Baqarah: 30)

Ayat ini memberitahukan bahwa malaikat sudah ada sebelum manusia ada. Karena Malaikat berkomentar tentang penciptaan manusia sebelum manusia diciptakan.

Di dalam Hadith yang shahih Rasulullah Saw menyebutkan bahwa malaikat diciptakan dari cahaya:

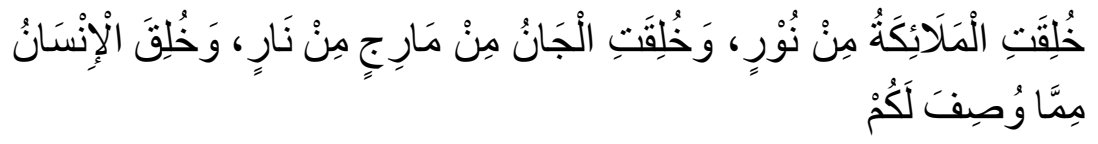

Malaikat diciptakan dari cahaya, dan Jin diciptakan dari kobaran api, dan manusia diciptakan sebagaimana yang telah disifatkan kepadamu.(HR Muslim)

\section{Nama-Nama Malaikat}

Tidak ada sumber yang menyebutkan jumlah malaikat seluruhnya, yang mengetahui hal ini hanyalah Allah Swt, dan Allah tidak mengungkapkan perkara ini sebagai cobaan bagi manusia seluruhnya. Allah berfirman:

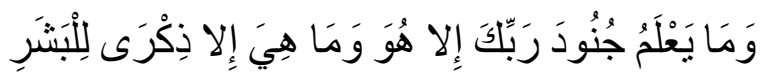

"Dan tidak ada yang mengetahui tentara Tuhanmu melainkan Dia sendiri. dan Saqar itu tiada lain hanyalah peringatan bagi manusia." (Al-Mudathir: 31)

Namun nama-nama malaikat ini dapat diketahui beberapa melalui sumber Al-Qur'an dan Al-Hadith, diantara nama-nama itu yang ada di dalam Al-Qur'an dan Al-Hadith adalah:

1. Jibril disebut sebagai pemimpin para malaikat dan yang menyampaikan wahyu kepada Allah Swt. 
2. Mikail bertugas untuk memberi rezeki.

3. Israfil bertugas untuk meniup sangkakala nanti di hari akhir.

4. Izra'il atau malaikat maut, penamaan malaikat maut dengan Izra'il tidak ada sumbernya dalam Al-Qur'an dan Al-Hadith.

5. Mungkar dan Nakir yang bertugas untuk menanyakan amal perbuatan selama berada di alam kubur.

6. Raqib dan Atid yang bertugas untuk mencatat amal kebaikan dan keburukan manusia.

7. Malaikat Malik yang bertugas untuk menjaga pintu neraka.

8. Malaikat Ridwan yang menjaga pintu surga.

9. Malaikat Harut dan Marut (Al-Baqarah: 102) mereka adalah malaikat yang diutus ke-negeri Babylonia, kisah isra'iliyyat mengenai Harut dan Marut banyak sekali dan tidak bisa dijadikan sandaran.

10. Malaikat pembawa 'Arsy (Ghafir:7 \& Al-Haaqqah: 17).

\section{Sifat-Sifat Malaikat}

Malaikat sebagai makhluk Allah yang selalu patuh dan tunduk kepadanya memiliki sifat-sifat yang mulia, diantara sifat-sifatnya sebagaimana yang dikabarkan dalam Al-Qur'an dan Al-Hadith adalah:

1. Malaikat itu berukuran besar, dan mereka memiliki sayap ada yang dua dan tiga, bahkan Jibril memiliki enam ratus ribu sayap.

2. Keindahan malaikat itu sangat luar biasa.

3. Malaikat mampu menyerupakan dirinya dengan manusia.

4. Malaikat tidak disifati degan laki-laki dan perempuan. 
5. Malaikat tidak pernah bosan dan lelah.

6. Tempatnya malaikat itu di langit.

7. Malaikat jumlahnya banyak, yang mengetahui hanya Allah.

8. Malaikat itu berakhlaq mulia dan selalau ta'at kepada Allah Swt.

9. Malaikat itu sangat pemalu.

10. Malaikat itu sangat cepat sekali.

11. Malaikat itu sangat disiplin dalam menjalankan segala urusannya.

\section{Syaithan Dan Jin ${ }^{139}$}

Jin adalah makhluk yang hidup di alam lain selain alam manusia dan malaikat, ada persamaan antara jin dan manusia diantaranya adalah kemampuan untuk mengetahui dan berfikir, dan kemampuan untuk memilih antara yang buruk dan yang baik. Kemudian diantara kelompok jin itu ada yang mu'min ada pula yang kafir, mereka seperti manusia diwajibkan untuk mengikuti syari'at agama Islam. Allah berfirman melalui ucapan para jin:

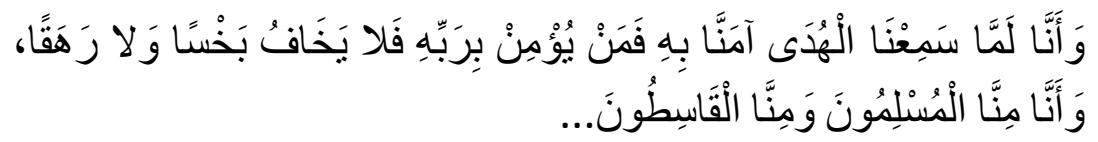

Sesungguhnya kami (jin) tatkala mendengar petunjuk (Al Quran), Kami beriman kepadanya. Barangsiapa beriman kepada Tuhannya, Maka ia tidak takut akan pengurangan pahala dan tidak (takut pula) akan penambahan dosa dan kesalahan. Sesungguhnya di antara kami ada orang-orang yang taat dan ada (pula) orang-orang yang menyimpang dari kebenaran. (Al-Jin: 13-16)

\footnotetext{
${ }^{139}$ Al-Ashqari, Al-'Aqidah 'Ala Dau'i I-Kitab Wa Sunnah. Jilid 3 ('Alamu I-Jinni wa s-Shayatin)
} 
Jika manusia diciptakan dari tanah, malaikat dari cahaya, sedangkan jin diciptakan dari api, Allah berfirman:

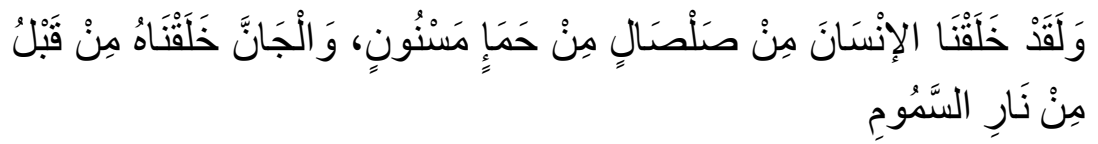

"Dan Sesungguhnya Kami telah menciptakan manusia (Adam) dari tanah liat kering (yang berasal) dari lumpur hitam yang diberi bentuk. 27. dan Kami telah menciptakan jin sebelum (Adam) dari api yang sangat panas." (Al-Hijr: 26-27)

Lalu siapakah syaithan atau iblis? mereka adalah bagian daripada jin yang pada mulanya ta'at kepada Allah Swt, namun karena mengingkari perintah Allah untuk sujud kepada Adam, maka Allah pun mengusirnya dari surga. Allah berfirman:

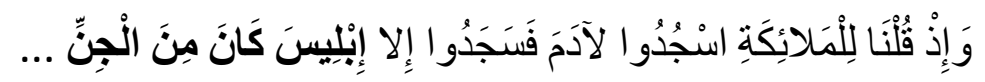

"Dan (ingatlah) ketika Kami berfirman kepada Para Malaikat: "Sujudlah kamu kepada Adam, Maka sujudlah mereka kecuali iblis. Dia adalah dari golongan jin." (Al-Kahfi : 50)

Diantara sifat dan tabi'at jin antara lain:

1. Jin dan syaithan mampu merubah penampakannya seperti manusia, maka diantara manusia ada yang melihat penampakan jin dalam bentuk orang yang sudah mati, bentuk hewan dsbg. Namun mereka tidak mampu menyerupai para nabi dan rasul.

2. Selain dapat menampakkan dirinya jin juga dapat merasuki manusia, dan mereka mampu masuk dan mengalir dengan aliran darah manusia.

3. Manusia dapat meminta bantuan kepada jin, dan takjub dengan yang terjadi karena melampaui kebiasaan umum, inilah yang disebut dengan sihir. 
4. Syaithan memiliki bentuk yang buruk dan memiliki tanduk.

5. Jin dan syaithan memiliki kekuatan dan kecepatan yang luar biasa.

6. Jin dan syaithan hidup di alam selain, alam manusia dan malaikat.

7. Jin dan syaithan mampu mempu memberi kabar kepada manusia. Dulu sebelum diutusnya nabi Muhammad Saw, jin dan syaithan mampu mencuri kabar di langit. Namun setelah diutusnya nabi Muhammad Saw mereka tidak dapat lagi mencuri kabar, karena akan dihujani oleh batu langit.

8. Jin dan syaithan tidak mampu mengganggu dan menguasai hamba Allah, bahkan mereka akan kabur dan menghindar jika bertemu dengan hamba Allah.

9. Jin dan syaithan tidak akan mampu memasuki pintu yang disebutkan nama Allah.

\section{KONSEKUENSI ETIS IMAN KEPADA HARI AKHIR DAN MAKHLUQ GHAIB}

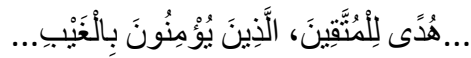

(Al-Qur'an adalah) petunjuk bagi mereka yang bertaqwa, (orang yang bertaqwa) adalah mereka yang beriman kepada yang ghaib....

Ayat ini menunjukkan bahwa seorang muslim harus beriman kepada yang ghaib, kata-kata ghaib menunjukkan kepada sesuatu yang tidak dapat ditinjau oleh panca indera manusia, walaupun ia ada baik "telah ada" atau "akan ada". Beriman kepada sesuatu yang tidak bisa ditangkap panca indera, kecuali hanya didengar melalui kabar-kabar dari Al-Qur'an dan Al-Hadith, menunjukkan level keimanan dan ketaqwaan seorang muslim. keimanan itu bukan 
hanya menjadi pengetahuan saja, namun ia harus menjadi worldview dalam bersikap dan bertindak. Pada pembahasan berikut akan dijelaskan tentang konsekuensi dari mengimani kepada hal-hal yang ghaib.

\section{Konsekuensi Iman Kepada Hari Akhir}

Orang-orang kafir dan musyrik yang tidak percaya kepada hari akhir tidak akan berhati-hati dan tidak akan takut akan datangnya hari itu. Hal ini mengakibatkan mereka tidak mau patuh terhadap perintah Allah, tidak mau bertaqwa dan tidak mau bersedekah.

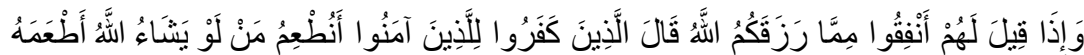

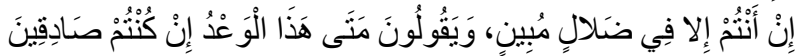

Dan apabila dikatakakan kepada mereka: "Nafkahkanlah sebahagian dari reski yang diberikan Allah kepadamu", Maka orang-orang yang kafir itu berkata kepada orang-orang yang beriman: "Apakah Kami akan memberi Makan kepada orang-orang yang jika Allah menghendaki tentulah Dia akan memberinya makan, Tiadalah kamu melainkan dalam kesesatan yang nyata". Dan mereka berkata: "Bilakah (terjadinya) janji ini (hari berbangkit) jika kamu adalah orang-orang yang benar?". (Yasin: 47-48)

Karena bagi orang kafir bertaqwa dan bersedekah tidak ada manfaatnya karena akhirat tidak akan pernah datang. Bagi orang-orang ini yang mampu menghancurkan mereka hanyalah masa; tidak ada hari akhir, tidak ada akhirat, tidak ada mizan, tidak ada hisab.

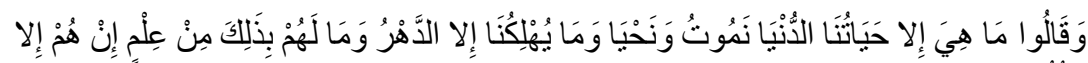
يَظُنُونَنَ

Dan mereka berkata: "Kehidupan ini tidak lain hanyalah kehidupan di dunia saja, kita mati dan kita hidup dan tidak ada yang akan membinasakan kita selain masa", dan mereka sekali-kali tidak mempunyai pengetahuan tentang itu, mereka tidak lain hanyalah menduga-duga saja. (Al-Jathiah: 24) 
Padahal yang mematikan dan menghidupkan adalah Allah Swt. Semua perbuatan manusia akan dihitung baik dan buruknya di akhirat sehingga akhirat disebut dengan tempat penentuan (daaru l-qarar). Sedangkan dunia hanyalah tempat yang sementara, di situ manusia diuji apakah ia iman ataukah ingkar (daaru l-bala').

Iman kepada hari akhir akan menciptakan sebuah akhlaq yang baik bagi setiap orang yang mengimaninya. Karena orang yang mengimaninya akan yakin bahwa semua apa yang ia lakukan di dunia akan direkam. Semua perbuatan dan perkataan baik dan buruknya, yang terletak di dalam batin maupun yang nampak, semuanya dicatat Allah Swt.

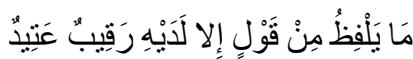

Tiada suatu ucapanpun yang diucapkannya melainkan ada di dekatnya Malaikat Pengawas yang selalu hadir. (Qaf: 18)

Pada hari itu, tidak ada seorangpun yang mampu mengelak dari perbuatan dan ucapan yang ia lakukan di dunia, hal ini karena semua anggota tubuhnya merekam perbuatan manusia.

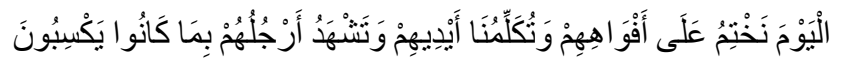

Pada hari ini Kami tutup mulut mereka; dan berkatalah kepada Kami tangan mereka dan memberi kesaksianlah kaki mereka terhadap apa yang dahulu mereka usahakan. (Yasin:65)

Jikalau video hanya mampu merekam bagian dari kisah kehidupan manusia, rekaman Allah Swt lebih detail lagi akan merekam setiap perbuatan dan ucapan manusia dari yang terbesar hingga yang terkecil, sehingga manusia akan mempertanggung jawabkan semuanya bahkan di setiap detik dari kehidupannya. ${ }^{140}$ Orang-orang kafir itu kemudian akan takjub dan kemudian berkata:

${ }^{140}$ Khan. $110-112$ 


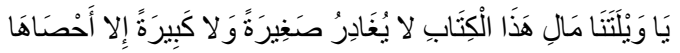
"Aduhai celaka Kami, kitab Apakah ini yang tidak meninggalkan yang kecil dan tidak (pula) yang besar, melainkan ia mencatat semuanya"(Al-Kahfi:49)

Karena seorang muslim menyadari datangnya hari akhir, maka ia akan lebih berhati-hati dan bertaqwa, jangan sampai perbuatan dan perkataannya meninggalkan catatan buruk, sehingga mengurangi timbangan amal baiknya di akhirat kelak.

Maka seorang yang beriman kepada hari akhir pasti akan bertaqwa dan berakhlaqu I-karimah, karenanya tidak berlebihan pernyataan Rasulullah Saw, bahwa orang yang beriman kepada Allah dan hari akhir pasti akan berbuat baik kepada tetangganya, tamunya, dan tidak akan berkata kecuali dengan perkataan yang baik.

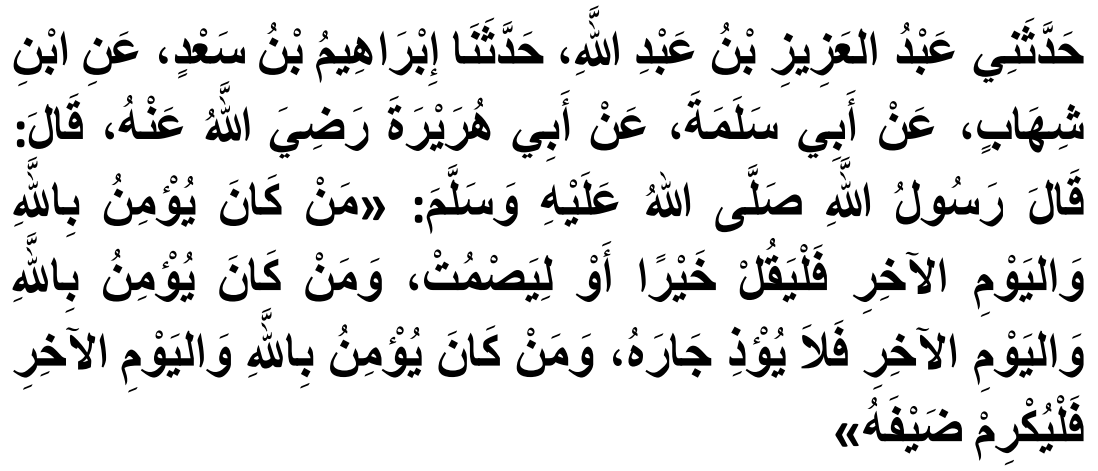

Rasulullah Saw bersabda: "Barang siapa beriman kepada Allah dan hari akhir maka ia akan berkata dengan perkataan yang baik atau diam, dan barang siapa beriman kepada Allah dan hari akhir maka ia tidak akan menyakiti tetangganya, dan barang siapa beriman kepada Allah dan hari akhir maka ia akan menghormati tamunya." ${ }^{141}$

Konsekuensi Iman Kepada Malaikat ${ }^{142}$

${ }^{141}$ Al-Bukhari. 8/100
${ }^{142}$ Al-Kharraz. 220-231 
Malaikat merupakan makhluq yang terdekat dengan Allah Swt. Mereka adalah makhluq yang ta'at kepada Allah dan tidak akan pernah bermaksiat kepada-Nya. Allah Swt seringkali mengutus malaikat kemuka bumi baik untuk menolong Rasulullah Saw dan kaum muslimin dalam peperangannya sebagaimana yang disebutkan dalam Al-Qur'an (Al-Anfal: 12). Juga disebutkan bahwa malaikat turun dalam ketika malam dan siang, ketika shalat subuh dan ashar (Bukhari-Muslim), ketika malam laylatu l-qadar (Al-Qadr:3), malaikat dekat dengan hamba Allah yang berdzikir (Bukhari-Muslim), malaikat berada di majelis ilmu (Muslim), malaikat mencatat kebaikan, kedatangan dalam shalat jum'at dan banyak lagi yang lainnya.

Berbagai hal di atas menunjukkan bahwa malaikat dekat dengan manusia dan menjadi saksi terhadap ketaatan dan kekufuran manusia. Malaikat akan mencintai orang-orang yang beriman dan senantiasa bertaqwa kepada Allah Swt. Tentunya orang yang beriman dan bertaqwa pasti akan mencintai malaikat, dan dicintai oleh malaikat sebagaimana Allah mencintai orang tersebut karena keimanan dan ketaqwaannya.

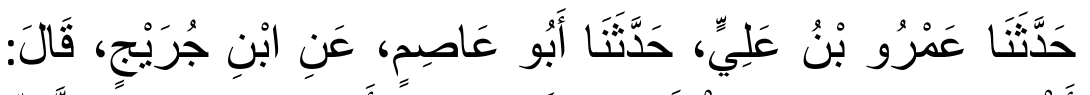

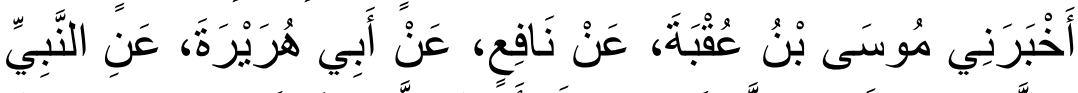

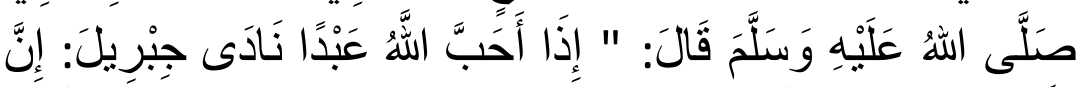

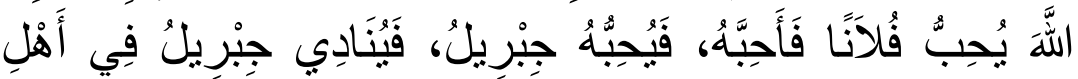

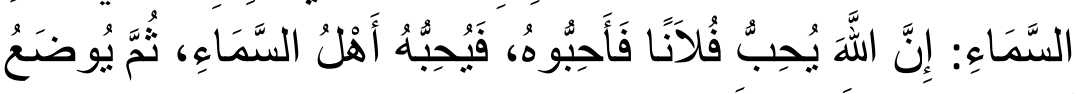

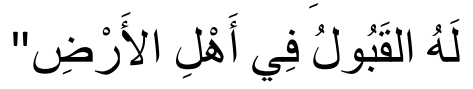

....Dari Abu Hurairah, Nabi Muhammad Saw bersabda: apabila Allah Swt mencintai hamba Jibril As akan berseru: "sesungguhnya Allah mencintai fulan maka cintailah ia, maka jibril mencintainya, kemudian jibril menyeru para penghuni langit: "sesungguhnya Allah mencintai fulan maka cintailah 
ia", kemudian penghuni langit mencintainya, kemudian akan diberikan baginya al-qubul kepada para penghuni bumi. Qubul: ia menjadi dicintai bagi penduduk bumi. ${ }^{143}$

Malaikat membenci orang-orang kafir dan akan menolong orang mu'min yang melawan orang kafir. Sebagaimana ketika perang Badar malaikat turun menolong kaum muslimin dalam memerangi kaum kafir.

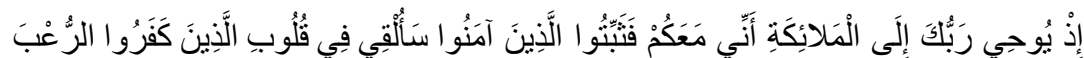

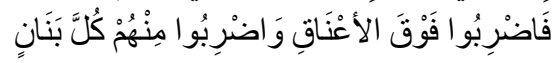

Tatkala Tuhanmu mewahyukan kepada Para Malaikat: "Sesungguhnya aku bersama kamu, Maka teguhkan (pendirian) orang-orang yang telah beriman". kelak akan aku jatuhkan rasa ketakutan ke dalam hati orang-orang kafir, Maka penggallah kepala mereka dan pancunglah tiap-tiap ujung jari mereka (Al-Anfal:12)

Oleh karenanya orang kafir akan menjadikan para malaikat sebagai musuh mereka, dan membenci malaikat, atau memusuhi mereka adalah bentuk kekufuran.

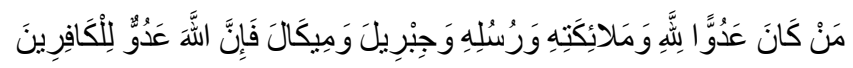

Barang siapa yang menjadi musuh Allah, malaikat-malaikat-Nya, rasul-rasul-Nya, Jibril dan Mikail, Maka Sesungguhnya Allah adalah musuh orang-orang kafir. (Al-Baqarah:98)

Kemudian termasuk akhlaq yang baik kepada malaikat adalah menjauhi dosa dan kemaksiatan, tanpa menyakiti mereka. Setiap orang pasti ingin dekat dengan malaikat, maka baginya agar tidak melakukan apa yang dibenci oleh Allah dan para malaikat, serta senantiasa melakukan ibadah dan berbagai kebaikan, sehingga sekelilingnya, termasuk rumahnya selalu bersama malaikat.

${ }^{143}$ Al-Bukhari. 8/14 
Mencintai malaikat tidak boleh berspekulasi asal-asalan terhadap mereka, seperti: menyebutkan malaikat itu perempuan dsbg semua sifat tentang malaikat harus berasal dari kabar yang benar dalam Al-Qur'an dan Al-Hadith. Apalagi jika terlalu mencintainya sehingga menyembah para malaikat, dan menjadikannya tuhan selain Allah.

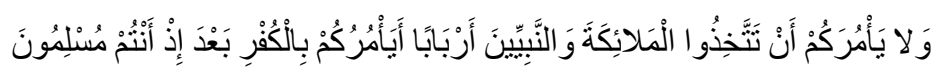

Dan (tidak wajar pula baginya) menyuruhmu menjadikan Malaikat dan Para Nabi sebagai tuhan. Apakah (patut) Dia menyuruhmu berbuat kekafiran di waktu kamu sudah (menganut agama) Islam?". (Ali Imran: 80)

Maka seorang mu'min akan mencintai malaikat sebatas sebagai makhluq yang beriman dan ta'at kepada Allah, tidak berlebih-lebihan dalam mencintainya.

\section{Konsekuensi Iman Kepada Iblis, Syaithan, dan Jin}

Eksistensi iblis merupakan antitesis dari eksistensi malaikat, jika malaikat adalah makhluq yang paling ta'at kepada Allah, sedangkan iblis adalah makhluq yang paling ingkar kepada Allah. Mengimani malaikat, iblis, syaitan dan jin adalah bagian dari keimanan kepada yang ghaib. Konsekwensinya bagi seorang yang mengimani eksistensi iblis, syaithan dan jin hal ini mengharuskannya bersikap iffah dan taqwa. Karena diciptakannya iblis untuk mengganggu manusia, sebagaimana permohonan iblis kepada Allah untuk ditangguhkan hingga hari akhir untuk mengganggu manusia sehingga manusia bersamanya masuk kedalam neraka.

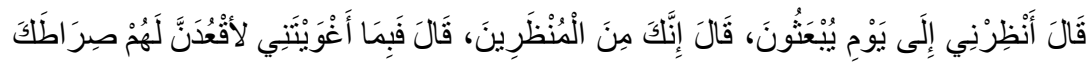
الْمُنْتَقِيمَ

Iblis menjawab: "Beri tangguhlah saya sampai waktu mereka dibangkitkan", Allah berfirman: "Sesungguhnya kamu termasuk mereka yang diberi tangguh." Iblis menjawab: "Karena Engkau telah menghukum saya tersesat, 
saya benar-benar akan menghalang-halangi mereka dari jalan-Mu yang lurus".. (Al-A'raf:14-16)

Godaan iblis hanya memiliki efek bagi manusia yang sejak awal memang sudah tersesat atau mudah tersesat, sedangkan bagi orang yang mu'min dan ikhlas dalam menyembah Allah tidak akan pernah mampu disesatkan oleh iblis.

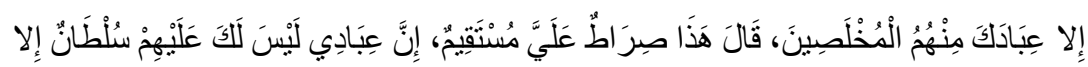

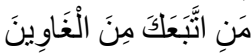

"Kecuali hamba-hamba-Mu yang mukhlis". Allah berfirman: "Ini adalah jalan yang lurus, Sesungguhnya hamba-hamba-Ku tidak ada kekuasaan bagimu terhadap mereka, kecuali orang-orang yang mengikut kamu, Yaitu orang-orang yang sesat. (Al-Hijr:40-42)

Diantara gangguan iblis, syaitan dan jin terhadap manusia adalah sihir, karena banyak manusia yang meminta bantuan, perlindungan, dan kabar-kabar tentang masa depan kepada jin.

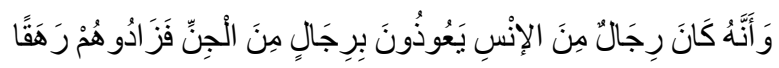

Dan bahwasanya ada beberapa orang laki-laki di antara manusia meminta perlindungan kepada beberapa laki-laki di antara jin, Maka jin-jin itu menambah bagi mereka dosa dan kesalahan. (Al-Jinn: 6)

Padahal jin sendiri tidak mengetahui hal tersebut, ada diantara mereka yang mengganggu manusia dengan menyebarkan berita bohong, ada pula jin-jin yang beriman kepadda Allah dan tidak melakukan hal tersebut.

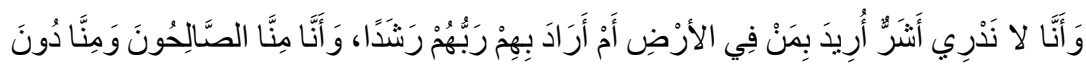

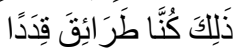

Dan Sesungguhnya Kami tidak mengetahui Apakah keburukan yang dikehendaki bagi orang yang di bumi ataukah Tuhan mereka menghendaki kebaikan bagi mereka. Dan Sesungguhnya di antara Kami ada orang-orang 
yang saleh dan di antara Kami ada (pula) yang tidak demikian halnya. adalah Kami menempuh jalan yang berbeda-beda. (Al-Jinn:10-11)

Berdasarkan ayat-ayat disurah Al-Jinn, seharusnya manusia tidak menyembah jin, karena mereka juga adalah makhluq Allah yang terkena taklif atau pembebanan syari'at, jika mereka ta'at maka mereka masuk kedalam surga dan jika ingkar maka akan masuk kedalam neraka. Dan jin tidak mampu memberikan bahaya ataupun manfaat bagi manusia, karena yang mampu melakukan itu hanyalah Allah Swt. 


\section{BAB V}

\section{QADA'-QADAR DAN WACANA AF'ALU L-'IBAD}

Pada bab ini akan dibahas tentang qada' dan qadar serta hubungannya dengan wacana af'alu l-ibad atau perbuatan manusia. Wacana ini penting untuk dibahas karena berkaitan dengan hubungan perbuatan manusia dengan taklif atau pembebanan syari'at dan pembalasan di akhirat.

\section{QADA' DAN QADAR (القضاع والثدر)}

Qada' dan qadar adalah perkara yang sulit untuk diterima oleh akal, namun wajib diimani, tanpa perlu untuk dipertanyakan. Definisi qada' dan qadar menurut Ibnu Hajar Al-Asqalani adalah:

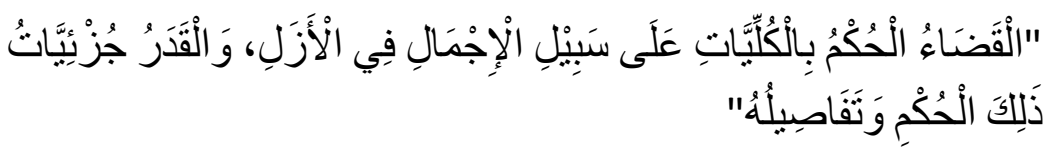

'Al-Qada' adalah hukum universal yang berlaku secara keseluruhan selamanya, dan Al-Qadar adalah ketentuan partikular dari hukum (universal) dan detailnya (dari yang universal)."144

Penjelasan lebih lanjut qada' adalah ketentuan Allah dalam ilmu-Nya terhadap perkara-perkara yang umum, atau Allah menentukan hukum-hukum yang berlaku universal. Misalkan: Allah telah menentukan bahwa semua benda yang dilempar keatas akan jatuh kebawah, setiap manusia pasti mati, matahari terbit dari timur dan tenggelam di barat, air mengalir dari atas kebawah, dsbg.

144 Ahmad bin 'Ali bin Hajar Al-'Asqalani, Fathu L-Bari Sharhu Sahih Al-Bukhari, ed. by Muhammad Fu'ad Abdul Baqi, Muhibbu d-Din Al-Khatib, and Abdu I-Azizi bin Abdullah bin Baz (Beirut: Daaru I-Ma'arif). 11/149\&477 
Jika qada' adalah terkait dengan hukum-hukum universal, sedangkan Qadar adalah ketentuan Allah terhadap perkara-perkara khusus, atau ketentuan Allah terhadap peristiwa-peristiwa tertentu. Misalkan: Allah mentakdirkan di tahun X, bulan X, hari X, pukul X si A meninggal dunia, atau terjadi suatu peristiwa bencana tertentu.

Mengimani qada' dan qadar Allah merupakan kewajiban bagi setiap muslim, bahwa segala sesuatu yang terjadi di dunia ini sudah sesuai dengan ketentuan Allah Swt, baik ketentuan yang bersifat hukum universal, ataupun ketentuan terhadap yang partikular.

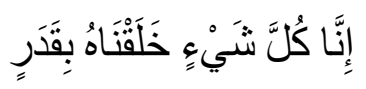

(Sungguh Kami ciptakan segala sesuatu menurut ukuran.” (Al-Qamar: 49“

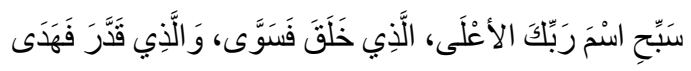

Sucikanlah nama Tuhanmu yang Maha Tinggi, yang Menciptakan, dan menyempurnakan (penciptaan-Nya), Dan yang menentukan kadar (masing-masing) dan memberi petunjuk (Al-A'la: 1-3)

Ketentuan Allah itu bersesuaian dengan Ilmu-Nya, dan pengetahuannya melingkupi segala sesuatu baik yang umum ataupun yang khusus.

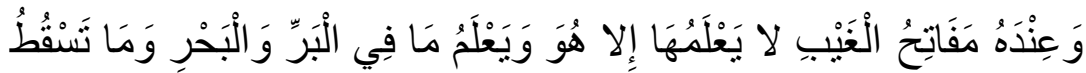

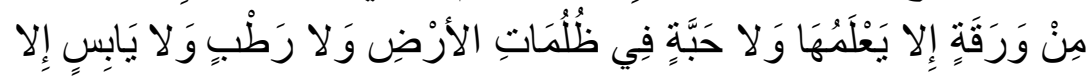
فِي كِتَابِ مُبِينٍ

Dan pada sisi Allah-lah kunci-kunci semua yang ghaib; tidak ada yang mengetahuinya kecuali Dia sendiri, dan Dia mengetahui apa yang di daratan dan di lautan, dan tiada sehelai daun pun yang gugur melainkan Dia mengetahuinya (pula), dan tidak jatuh sebutir biji-pun dalam kegelapan bumi, dan tidak sesuatu yang basah atau yang kering, melainkan tertulis dalam kitab yang nyata (Lauh Mahfudz)" (Al-An’am:59) 
Kemudian melalui ketentuan yang ada dalam ilmu-Nya, Allah menciptakan segala sesuatu dengan kehendak-Nya (iradah) dan kekuatan-Nya (qudrah). Kehendak dan kekuatan Allah tidak mungkin menyelisihi ilmu-Nya, karena jika Allah berkehendak menyelisihi ilmu-Nya maka ilmu itu tidak sempurna.

Maka kesimpulannya, mengimani qada' dan qadar berarti mengimani bahwa Allah memiliki kesempurnaan ilmu, kesempurnaan kehendak, dan kekuasaan. Menafikan qada'dan qadar berarti menafikan itu semua, berarti meyakini bahwa Allah tidak berilmu, tidak berkehendak, dan tidak berkuasa, atau dengan kata lain Allah tidak sempurna.

\section{WACANA AF'AL U L-'IBAD (PERBUATAN MANUSIA)}

Ada problematika moral ketika keharusan untuk mengimani qada' dan qadar dikaitkan dengan perbuatan manusia.

Dimulai dengan masalah kesempurnaan ilmu Allah, berarti Allah mengetahui segala hal baik yang ada di masa lalu ataupun di masa yang akan datang. Allah juga mengetahui dari yang universal hingga yang partikular. Dan pengetahuan Allah tidak akan pernah salah. Masalah ilmu ini jika dikaitkan dengan perbuatan manusia, "apakah perbuatan manusia di masa yang akan datang, ada dalam ilmu Allah Swt?" karena jika perbuatan manusia ada dalam ilmu Allah, maka ketika manusia berbuat sesuatu, perbuatan itu sudah ditetapkan Allah dalam ilmunya, dan apa yang dilakukan manusia pasti sesuai dengan ilmu Allah. Berarti manusia "dipaksa" oleh ilmu Allah dalam menghasilkan berbagai perbuatannya. Jika demikian maka kehidupan manusia tidak lain hanyalah seperti film yang diputar. 
Masalahnya ketika perbuatan itu berkaitan dengan pahala dan dosa, karena perbuatan yang mengandung pahala dan dosa mengharuskan adanya kehendak bebas. Ketika Allah memaksa seseorang berbuat baik atau buruk dan memberikan balasan atas perbuatannya, Allah menjadi tidak adil, karena ahli maksiat "dipaksa" untuk bermaksiat dan dihukum karena kemaksiatannya, orang yang taat juga "dipaksa" untuk taat dan diberi pahala dengan ketaatannya. Hal ini menjadikan manusia seperti robot yang sudah diprogram sedemikian rupa, kemudian ketika robot itu berbuat yang tidak diingini oleh pemiliknya, pemilikinya menghukumnya. Tentunya menghukum robot itu adalah suatu perbuatan yang irrasional. Sehingga jika perbuatan manusia "dipaksa" maka syari'at menjadi tidak berguna lagi.

Maka setiap orang harus memiliki "kebebasan memilih" antara ketaatan dan kemaksiatan, sehingga orang yang taat diberi pahala atas ketaatannya, dan orang yang bermaksiat dihukum berdasarkan kemaksiatannya. Namun penjelasan "kebebasan memilih" jika dikaitkan dengan ilmu Allah, maka pertanyaannya "apakah Allah tahu pilihan manusia tentang pilihan seseorang?", jika Allah tahu, "apakah manusia mungkin untuk mengubah ilmu Allah?", jika Allah tidak tahu tentang pilihan seseorang, ataupun manusia mampu untuk mengubah ilmu Allah, maka ilmu Allah itu menjadi tidak sempurna.

Kemudian pertanyaan "apakah perbuatan manusia baik dan buruknya adalah perbuatan Allah atau perbuatan manusia?" karena jika dikatakan itu perbuatan manusia berarti Allah tidak memiliki kekuasaan apapun dalam menciptakan perbuatan manusia, dan jika itu adalah perbuatan Allah berarti manusia tidak memiliki peran dalam mengadakan perbuatannya sendiri. Begitulah diskusi dalam masalah ini selalu berputar tanpa akhir. 
Perbedaan kedua hal ini disebabkan karena ayat Al-Qur'an ada yag menunjukkan bahwa manusia bebas memilih dan ada yang menunjukkan bahwa perbuatannya dipaksa. Diantara ayat yang menunjukkan kebebasan memilih:

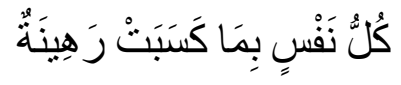

Tiap-tiap diri bertanggung jawab atas apa yang telah diperbuatnya (Al-Mudathir: 38)

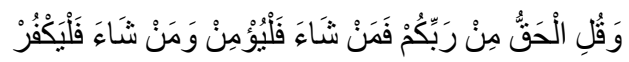

Dan Katakanlah: "Kebenaran itu datangnya dari Tuhanmu; Maka Barangsiapa yang ingin (beriman) hendaklah ia beriman, dan Barangsiapa yang ingin (kafir) Biarlah ia kafir". (Al-Kahfi:29)

Sedangkan ayat yang meenunjukkan bahwa perbuatan manusia dipaksa antara lain:

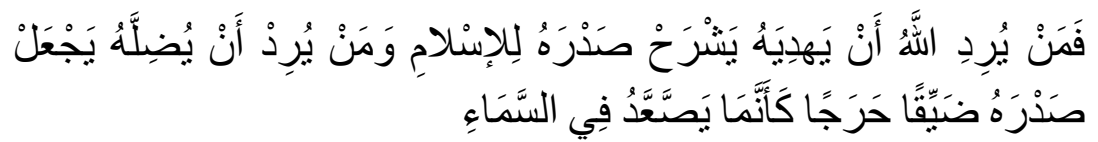

Barangsiapa yang Allah menghendaki akan memberikan kepadanya petunjuk, niscaya Dia melapangkan dadanya untuk (memeluk agama) Islam. dan Barangsiapa yang dikehendaki Allah kesesatannya, niscaya Allah menjadikan dadanya sesak lagi sempit, seolah-olah ia sedang mendaki langit. (Al-An'am:125)

$$
\text { وَالََُّّ خَلَقَكُمْ وَمَا تَعْمَلُونَ }
$$

Padahal Allah-lah yang menciptakan kamu dan apa yang kamu perbuat itu". (As-Shaffaat: 96)

Dalam sejarah Islam terdapat dua firqah atau sekte kalam yang paling ekstrim dalam mensikapi masalah ini yakni adalah Jabariyyah dan Qadariyyah. Jabariyyah juga disebut dengan Jahmiyyah yakni pegikut Jahm bin Shafwan yang memandang bahwa manusia tidak memiliki kekuatan dan kuasa dalam mengadakan 
perbuatan, yang mengadakan perbuatannya adalah Allah Swt. Dan semua perbuatan manusia baginya dipaksa oleh Allah Swt. ${ }^{145}$ Sedangkan Qadariyyah merupakan pengikut Al-Ghilan Ad-Dimashqi, menurutnya bahwa manusia bebas dengan perbuatannya manusia, perbuatan manusia adalah miliknya bukan perbuatan Allah dan tidak diciptakan oleh Allah. Pendapat Qadariyyah ini kemudian diikuti oleh sekte Mu'tazilah. ${ }^{146}$

\section{Kebebasan Manusia Perspektif Mu'tazilah}

Problem perbuatan manusia bagi sekte Mu'tazilah adalah bagian dari permasalahan keadilan Allah (العدل) yang merupakan salah satu dari 5 pokok keimanan mereka. Menurut Mu'tazilah Allah itu adil dalam dzat ataupun sifat-Nya. Karena adil maka Allah akan selalu berbuat kebaikan dan tidak akan berbuat keburukan; Allah tidak mungkin berdusta, tidak mungkin melanggar hukumnya, tidak mungkin menghukum anak kecil atas dosa bapaknya, tidak mungkin memberikan beban kepada hambanya tentang apa yang ia tidak mampu atau tidak diketahui. Kemudian jika Allah menjadikan seseorang sakit atau menjadikan suatu musibah atau bencana maka sebenarnya itu adalah untuk kebaikan bagi orang tersebut, karena Allah lebih mengetahui tentang dirinya daripada ia sendiri. ${ }^{147}$

Karena Allah harus adil, khususnya dalam masalah taklif (pembebanan shari'at) maka manusia harus bebas memilih dalam perbuatannya. Karena ketika manusia bebas memilih, Allah mampu adil dalam memberikan balasannya, yang demikian itu tidak dapat

\footnotetext{
145 Yasir Al-Qadi, Maqalat Al-Jahm Bin Shafwan Wa Atharuha Fi l-Firaq Al-Islami, 1st edn (Riyad: Daaru Adwa'u s-Salaf, 2005). P.713

${ }^{146}$ Yahya bin Abi I-Khayr Al-'Imrani, Al-Intishar Fi Raddi 'ala I-Qadariyyah Wa I-Mu'tazilah Al-Ashrar (Madinah: Daaru Adwa'u s-Salaf). P.671

147 Hanim Ibrahim Yusuf, Ashlu L-'Adl 'inda I-Mu'tazilah, 1st edn (Nasr: Daaru I-fikri Al-'Araby, 1993) p.68; Abdu r-Rahman Al-Badawi, Madhahibu L-Islamiyyin (Beirut: Daaru I-'Ulum li I-Maliyyin, 1997). P.60-61
} 
dimungkinkan jika perbuatan manusia dipaksa oleh Allah. Karena ketika perbuatan manusia dipaksa, maka perbuatan itu bukan milik manusia tetapi milik Allah Swt. dan Allah tidak mungkin memberikan balasan bagi perbuatan-Nya sendiri. ${ }^{148}$ Maka manusia bebas memilih untuk perbuatannya, dan ialah pelaku bagi perbuatannya bukan lainnya. Al-Qadi Abdu I-Jabbar salah satu tokoh Mu'tazilah yang ternama berkata:

"Kemampuan (dalam menghasilkan perbuatan) bagi kami adalah kemampuan untuk dua hal yang bertentangan (baik dan buruk), dan seorang mukallaf (orang yang terkena pembebanan shari'at) harus mampu untuk melakukan keduanya. Dan Allah Swt tidak menolak atau mewajibkan (bagi seseorang) atas salah satunya (baik dan buruk). Kemudian Allah tidak memberikan manusia bantuan dalam menghasilkan perbuatannya, karena jika Allah membantu manusia hal ini berarti telah mengeluarkan seorang mukallaf dari taklif."149

Kemudian menurut Mu'tazilah, secara psikologis dalam diri manusia telah terdapat al-lutfu l-ilahy (اللطف الإلهي) yakni segala sesuatu yang mendorong manusia pada ketaatan dan menjauhkan dari kemaksiatan. Hal ini karena Allah menginginkan bagi hambanya keimanan dan Allah tidak rido terhadap kekufuran. Namun jika hanya ada lutf ilahi saja maka semua orang akan menjadi beriman dan tidak ada balasan. Oleh karenanya Allah ciptakan bagi manusia syahwat; yakni sesuatu yang mendorong manusia kepada keburukan dan kemaksiatan. Agar kemudian dapat diketahui siapa yang menuruti akal dan kalbunya dan siapa yang menuruti syahwatnya. Dengan demikian dalam diri manusia terdapat dua dorongan yang dapat

148 Muhammad 'Imarah, Al-Mu'tazilah Wa Mushkilatu I-Hurriyyah Al-Insaniyyah, 2nd edn (Kairo: Daaru s-Syuruq, 1988). P.70-85

${ }^{149}$ Abdu I-Qadi Abdu I-Jabbar Al-Asadi Al-Aabaadi Al-Hamdani Al-Mu'tazili, Al-Mughni Fi Abwabi t-Tauhid Wa l-'Adl (Mesir: Wizarah Al-Thaqafah Al-Mishriyyah). P.289 
dipilih oleh manusia, yakni kecendrungan kepada kebaikan dan keburukan. ${ }^{150}$

Kemudian "apakah mungkin bagi Allah untuk memerintahkan seseorang untuk beriman, sedangkan Allah tahu bahwa ia tidak akan beriman?" Al-Qadi Abdu I-Jabbar menjawab bahwa seseorang yang mampu untuk ingkar pasti ia juga mampu untuk beriman. Ketika Allah menurunkan hidayahnya, Allah akan memperkuat dorongan-dorongan baik eksternal maupun internal dalam diri orang tersebut agar beriman, namun orang itu akan memilih kekufuran karena syahwatnya. ${ }^{151}$ Dan Allah pun tahu bahwa tidak mungkin orang itu menjadi mu'min dan kafir secara bersamaan, pasti ia berada dalam salah satu keadaan. Dalam berbicara mengenai Ilmu Allah ini Qadi tidak berbicara panjang, karena pasti akan terjebak dalam diskusi yang tidak ada habisnya. ${ }^{152}$

Kemudian "bagaimanakah kelompok Mu'tazilah menjelaskan ayat-ayat yang menunjukkan bahwa Allah menciptakan perbuatan manusia?" hal ini bisa dirujuk kedalam Tafsir Al-Kasyaf karya Al-Zamakhsyari salah seorang ulama' bahasa dan tafsir beraliran Mu'tazilah. Ketika ia menafsirkan ayat:

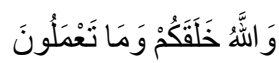

Padahal Allah-lah yang menciptakan kamu dan apa yang kamu perbuat". (As-Shaffaat: 96)

\footnotetext{
${ }^{150}$ Amal Fathullah Zarkasyi, IImu L-Kalam; Tarikhu I-Madhahib Al-Islamiyyah Wa Qadayaha Al-Kalamiyyah (Ponorogo: Jaami'atu d-Daaru s-Salaam, 2006). P.149

${ }^{151}$ Al-Mu'tazili, Al-Mughni Fi Abwabi t-Tauhid Wa l-'AdI. P.289-293

${ }^{152}$ Abdu I-Qadi Abdu I-Jabbar Al-Asadi Al-Aabaadi Al-Hamdani Al-Mu'tazili, Sharh Ushuli L-Khamsah, 3rd edn (Mesir: Maktabah Wahbah, 1996). P.409-421
} 
Maksud dari ayat ini adalah bahwa Allah menciptakanmu dan apa yang kamu buat dari berhala-berhala itu. Menurutnya Allah menciptakan substansi material dari berhala, kemudian manusialah yang membentuknya sehingga menjadi berhala. ${ }^{153}$ Padahal pemahaman yang benar terhadap ayat ini bahwa Allah menciptakan semua yang membuat dan segala apa yang ia perbuat, sebagaimana yang disebutkan Ibnu Kathir dalam tafsirnya. ${ }^{154}$

\section{Teori Kasb Perspektif Abu Hasan Al-‘Ash'ari}

Imam Abu Hasan Al-'Ash'ari (260 H/873 M sampai 324 H/935 M) lahir di Basrah dan meninggal di Baghdad, ia merupakan keturunan dari Abu Musa Al-Ash'ari salah seorang sahabat Nabi Saw. Pada mulanya ia adalah pengikut Mu'tazilah dengan guru sekaligus ayah tirinya Al-Jubba'i (915 M) yang merupakan salah satu ulama' terkemuka Mu'tazilah. Namun kemudian ia berikrar untuk tobat dan keluar dari Mu'tazilah setelah bermimpi bertemu dengan Nabi Muhammad Saw, kemudian menelorkan fikiran-fikirannya dan dinisbatkan kepada pemikiran kalam Imam Ahmad bin Hanbal. Dalam pemikiran kalam, Al-Ash'ari mengkritik dan menolak hampir seluruh pemikiran Mu'tazilah.

Dalam masalah af'alu l-'ibad, Al-Ash'ari menolak pendapat bahwa manusia adalah pelaku bagi perbuatannya sendiri. ia berpendapat bahwa orang kafir tidak akan kafir kecuali ia meyakini bahwa kekufuran yang dilakukannya adalah benar. Karena kalau ia sendiri yang menjadi pelakunya pasti ia tahu bahwa itu salah. Maka pastilah itu adalah kehendak Allah. Allah Swt, menurut Al-Ash'ari berkehendak dengan apapun yang dikehendaki, dan semua yang ada

153 Abu Qasim Mahmud bin Umar Al-Zamakhsyari, Al-Kasyaf Fi Haqaiqi Ghawamidi t-Tanzil, Wa 'Uyuni l-Aqawil Fii Wujuhi t-Ta'wil, 1st edn (Riyad: Maktabah Al-Abykan, 1998). 5/219-220 ${ }^{154}$ Al-Katsir. 12/35-36 
dalam kekuasaann Allah pasti ia kehendaki, karena jika ada sesuatu terjadi di luar dari kehendak-Nya itu menjadikan lalai sebagai sifat Allah. ${ }^{155}$ Pada tataran ini pemikiran Imam Al-Ash'ari dalam af'alu I-'ibad masih sama dengan pemikiran Jabariyyah.

Al-Ash'ari, sebagaimana Mu'tazilah membagi fi'il atau perbuatan manusia menjadi dua yakni "perbuatan yang dipaksa" (al-fi'l al-idtiraary) dan "perbuatan yang memilih" (al-fi'l al-iraady al-ikhtiyaary). Untuk "perbuatan yang dipaksa" seperti berjalannya darah keseluruh tubuh, berdetaknya jantung, berkedipnya mata, bernafas dsbg. Al-Ash'ari menyebutkan bahwa pelaku dari perbuatan-perbuatan itu pada hakikatnya adalah Allah Swt, bukan yang lainnya. ${ }^{156}$ Berdasarkan pendapat itu, para ulama' Asha'riyyah (pengikut Imam Al-Ash'ari), seperti Imam Al-Ghazali, menafikan sebab dan akibat, bahwa benda yang jatuh bukan karena gaya gravitasi, benda terbakar bukan karena masuk kedalam perapian dsbg. namun semua itu terjadi karena Allah Swt yang menjadikannya jatuh dan yang menjadikannya terbakar. Dan Allah bagi Imam Al-Ghazali adalah penyebab semua akibat.

Sedangkan untuk "perbuatan yang memilih", yakni perbuatan yang memungkinkan manusia untuk memilih perbuatan tersebut seperti: manusia memilih untuk makan atau tidak, belajar atau tidur dsbg, Al-Ash'ari berpendapat bahwa pelaku yang hakiki dari perbuatan ini adalah Allah Swt. Namun bukan berarti manusia tidak memiliki peran dalam terwujudnya perbuatan tersebut. Untuk menunjukkan peran manusia, Al-Ash'ari menawarkan teori al-kasb atau usaha. Maksudnya adalah manusia berusaha dan

155 Mahmud Gharabah, Abu L-Hasan Al-Ash'ari (Kairo: Al-Matabi' Al-Amiriyyah, 1983) p.96-99; Abu Hasan Al-Ash'ari, Al-Ibanah 'an Ushuli $d$-Diyanah, 5th edn (Madinah: Al-Mamlakah Al-Su'udiyyah Al-'Arabiyyah). p. 189

${ }^{156}$ Al-Ash'ari, Al-Luma' Fi Raddi 'Ala Ahli z-Zayghi Wa I-Bida'. P.73 
mengusahakan sebuah perbuatan, namun ia tidak mampu mengadakan semua usahanya itu, yang mengadakan perbuatan itu adalah Allah Swt. Atau dengan kata lain usaha manusia tidak mampu memberikan pengaruh bagi terwujudnya sebuah perbuatan, yang mampu mewujudkannya adalah Allah Swt. Disini manusia menjadi pelaku fiktif (al-fa'il al-majazy), sedangkan Allah adalah pelaku yang sebenarnya (al-fa'il al-haqiqi). ${ }^{157}$ Misalkan seseorang ingin pergi ke masjid untuk shalat berjama'ah dan dia mengusahakannya untuk dapat mewujudkan hal tersebut, jika ia shalat berjama'ah berarti Allah menjadikannya untuk shalat, namun jika ia terhalang untuk shalat berjama'ah berarti Allah tidak menjadikannya. Oleh karenanya dalam ayat:

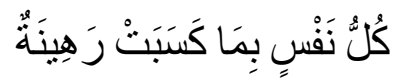

Tiap-tiap diri bertanggung jawab atas apa yang telah diperbuatnya (Al-Mudathir: 38)

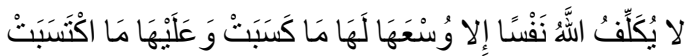

Allah tidak membebani seseorang melainkan sesuai dengan kesanggupannya. ia mendapat pahala (dari kebajikan) yang diusahakannya dan ia mendapat siksa (dari kejahatan) yang dikerjakannya. (Al-Baqarah:286)

Kedua ayat ini menunjukkan bahwa apa yang dipertanggung jawabkan manusia di akhirat adalah usahanya. Yakni usaha dalam mengadakan sebuah perbuatan, apakah usahanya itu untuk menghasilkan perbuatan yang baik ataukah buruk. Namun ia bukan pelaku yang sebenarnya dari perbuatan itu, pelaku sebenarnya tetaplah Allah Swt.

157 Muhammad Ibrahim Al-Fuyumi, Syaikh Ahlu S-Sunnah Wa I-Jama'ah Al-Imam Abu I-Hasan Al-Ash'ari; Fahs Naqdy Li 'Ilmi I-Kalam Al-Islamy, ed. by 2003, 1st edn (Kairo: Daaru I-Fikri Al-'Araby, 2003). P.385 
Disini terlihat bahwa pemikiran Imam Al-Ash'ari mendekati Jabariyyah, namun dengan adanya teori kasab, menjadikan posisinya sebagai penengah antara Jabariyyah dan Qadariyyah. Namun masih lebih dekat ke-Jabariyyah. Oleh karenanya Ibnu Hazm Al-Andalusi membagi Jabariyyah kedalam 2 kelompok: Pertama adalah Jabariyyah murni, mereka adalah pengikut Jahm bin Shafwan, Kedua adalah Jabariyyah pertengahan mereka adalah kelompok Ash'ariyyah.

\section{Teori Kasb Perspektif Imam Al-Maturidi}

Imam Abu Mansur Al-Maturidi (233 H/853 M sampai 333 $\mathrm{H} / 944 \mathrm{M}$ ) berasal dari keturunan Abu Ayyub Al-Anshari di Madinah, ia dilahirkan di desa Maturid, Samarkand sekarang berada di negara Uzbekistan. Al-Maturidi mengadopsi pola fikir dan madhab Imam Abu Hanifah, karena di Samarkand yang berkembang adalah madhab Hanafiyyah. Jika dilihat dari tahun kematiannya Al-Maturidi hidup sezaman dengan Al-Ash'ari walaupun keduanya belum pernah bertemu.

Al-Maturidi mengkritik pemikiran Jabariyyah dan Qadariyyah. Menurutnya jika perbuatan manusia disebut sebagai perbuatan Allah secara mutlak maka fungsi dari perintah dan larangan, ketaatan dan kemaksiatan menjadi sirna. Karena Allah tidak mungkin memerintahkan sesuatu kepada seseorang, padahal perbuatan orang itu adalah fiktif, dan jika demikian tidaklah berguna balasan di akhirat. Begitupula jika penyandaran perbuatan manusia kepada manusia itu sendiri secara mutlak dengan alasan pembebanan syari'at dan balasannya di akhirat, ini mengakibatkan bahwa Allah Swt tidak memiliki peran dalam perbuatan hambanya, juga menafikan peran Allah sebagai pengatur semua yang ada, 
sehingga Allah tidak memiliki kekuasaan dalam menentukan perbuatan hambanya. ${ }^{158}$

Kemudian Al-Maturidi menyebutkan posisinya dari dua kelompok ini, menurutnya bahwa perbuatan manusia pada hakikatnya adalah perbuatan Allah, karena Allah lah yang menciptakan perbuatan tersebut. Sedangkan manusia mengusahakan bagi terwujudnya perbuatan tersebut. Pada tataran ini pemikiran Al-Maturidi sama dengan Al-Ash'ari dalam teori kasb namun yang membedakan antara keduanya adalah Al-Maturidi melihat bahwa manusia dalam mengusahakan perbuatannya masih memiliki pengaruh bagi terwujudnya niat dan perbuatan, namun yang mampu mengadakan atau menciptakan perbuatan tersebut secara riil adalah Allah Swt. Sehingga perbuatan manusia disandarkan kepada Allah di satu sisi, namun tidak menafikan bahwa itu adalah perbuatan manusia secara riil bukan fiktif. ${ }^{159}$

Dalam Tafsir Al-Maturidi Ta'wilaat Ahlu s-Sunnah, Al-Maturidi menafsirkan surah Ar-Ra'd: 11.

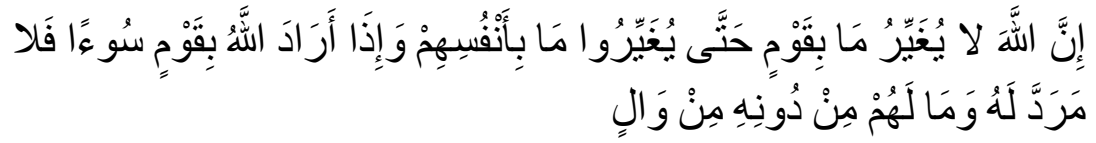

Sesungguhnya Allah tidak merobah Keadaan sesuatu kaum sehingga mereka merobah keadaan yang ada pada diri mereka sendiri. dan apabila Allah menghendaki keburukan terhadap sesuatu kaum, Maka tak ada yang dapat menolaknya; dan sekali-kali tak ada pelindung bagi mereka selain Dia.(Ar-Ra'd:11)

Dalam ayat ini ia menfsirkan bahwa Allah tidak merubah keadaan suatu kaum menjadi lebih baik hingga mereka merubah diri mereka

\footnotetext{
${ }^{158}$ Abu Manshur Muhammad bin Muhammad Al-Maturidi, Kitab At-Tauhid (Beirut: Daar Shadir, 2001). P.305

${ }^{159}$ Sa'ad 'Abdullah 'Ashur, Mawqifu L-Firaq Al-Islamiyyah Min Af'ali I-'Ibad, 2nd edn (Majallah Al-Jaami'ah Al-Islamiyyah, 2001). P.233-274
} 
sendiri. Walaupun demikian kaum itu dalam merubah dirinya hanya pada tataran usaha, sedangkan perubahan dan pembaharuan dalam dirinya adalah dari Allah Swt. maka dilanjutan ayat itu, "jika Allah berkehendak keburukan bagi suatu kaum maka tidak akan ada yang mampu menghalanginya", ayat ini menunjukkan kesalahan Mu'tazilah mereka mengatakan bahwa Allah tidak menginginkan sesuatu bagi manusia kecuali itu baik bagi agama mereka. Mu'tazilah telah memaksa bahwa Allah tidak memiliki kehendak yang buruk, padahal di ayat ini menunjukkan bahwa Allah juga mampu menginginkan keburukan. ${ }^{160}$

\section{Teori Kasb Perspektif Ibnu Taymiyyah dan Ibnu Qayyim Al-Jauziyyah (Salafi)}

Ibnu Taymiyyah (661 H/1263 M sampai 728 H/1328 M) dan muridnya Ibnu Qayyim Al-Jauziyyah (691 H/1292 M sampai 751 H/1292 M sampai 751 H/1350 M) merupakan dua ulama' yang bermadhab Hanbali baik dalam masalah aqidah dan fiqh, namun pada perkembangannya keduanya menolak untuk fanatis terhadap satu madhab tertentu. Karena di masa Ibnu Taymiyyah dan Ibnu Qayyim merupakan masa fanatisme madhab yang mengakibatkan kemunduran berfikir pada masa itu. Diantara corak pemikiran keduanya adalah berpegang kepada Al-Qur'an dan Al-Hadith yang sahih, pemikiran shahabat, dan jejak-jejak ulama' salaf. Dalam memahami Al-Qur'an sesuai dengan apa yang dipahami oleh Nabi dan dibantu dengan perkataan ulama' salaf atau ulama' yang hidup pada 3 abad pertama hijriyyah. Mereka menolak berbagai jenis interpretasi yang keluar dari Nabi dan para ulama' salaf, bahkan dalam menginterpretasikan ayat-ayat yang mutasyabihat. Posisi akal harus bersesuaian dengan teks, dan akal tidak boleh melebihi

160 Abu Manshur Muhammad bin Muhammad Al-Maturidi, Tafsir Al-Maturidi; Ta'wilat Ahli s-Sunnah, ed. by Majdi Baslum, 1st edn (Beirut: Daaru I-Kutub al-IImiyyah, 2005). P.327 
batasnya, karena akal bertugas sebagai alat untuk memahami teks, metode ini disebut dengan mendahulukan teks daripada akal (تقديم تُ sering disebut dengan Salafi, atau pengikut salaf, walaupun kurun masa hidupnya jauh dari 3 abad pertama, hal ini berbeda dengan para pendahulunya yakni Imam Al-Ash'ari dan Imam Al-Maturidi yang merupakan ulama' salaf karena hidup di abad ke-3 $\mathrm{H}$.

Dalam masalah af'alu l-'ibad, Ibnu Taymiyyah dan Ibnu Qayyim membagi kehendak Allah menjadi 2: Pertama, kehendak dan ketentuan Allah terhadap semua yang wujud/eksis (أمر كوني قدري). Kedua, kehendak Allah dalam masalah agama (أمر ديني شر عي).

Kehendak Allah terhadap semua yang wujud yaitu kehendak Allah terhadap semua yang diciptakan dan tidak ada satupun di luar kehendak Allah. Kemudian taqdir Allah menentukan segala sesuatu, termasuk perbuatan manusia, baik dan buruk, ketaatan dan kemaksiatan, iman dan kafir. Namun dengan adanya taqdir itu perbuatan hamba tidak dipaksa, karena Allah telah memberikan kemampuan dan kehendak bebas untuk memilih bagi manusia; jika ia hendak beriman maka ia akan beriman dan jika ia ingkar maka ia kafir. Dengan demikian manusia adalah pelaku sebenarnya bagi perbuatannya. Allah menghendaki seseorang untuk menjadi kafir, karena orang itu ingin kafir. ${ }^{163}$

161 Sa'id Abdu Al-'Adhim, Manhaju S-Syaikhu I-Islam Ibnu Taymiyyah As-Salafi Wa Da'watuhu Al-Islahi (Iskandariyyah: Daaru I-Iman). P.36-41

162 Abu Abdillah Muhammad bin Abi Bakr Bin Ayyub Ibnu I-Qayyim Al-Jawziyyah, Shifa'u l-'Alil Fi Masa'ili I-Qada' Wa l-Qadar Wa l-Hikmah Wa t-Ta'lil (Kairo: Maktabah Daaru t-Turath). P.105; Taqiyuddin Ahmad Ibnu Taimiyyah, Al-Mustadrak 'ala Majmu'i l-Fatawa: Al-Mujallad Al-Awwal Mina l-'Aqa'id Ila t-Tafsir (Saudi). P.139

163 Taqiyuddin Ahmad Ibnu Taimiyyah, Al-Fatawa Al-Humiyyah Al-Kubra, ed. by Hamad bin Abdu I-Muhsin At-Taujiri, 2nd edn (Riyad: Daaru s-Shami'i, 2004). P.426-427 
Kemudian kehendak Allah dalam masalah agama berkaitan dengan apa yang disukainya dan diridohinya. Dengan kehendak ini, Allah menyukai keimanan dan ketaatan hamba-hambanya. Namun Allah tidak menyukai dan meridohi kekufuran, diantara ayat Al-Qur'an yang membuktikan itu adalah:

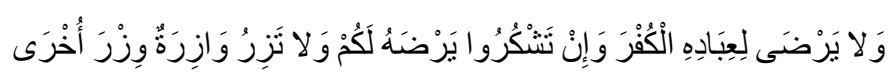

Dan Dia tidak meridhai kekafiran bagi hamba-Nya; dan jika kamu bersyukur, niscaya Dia meridhai bagimu kesyukuranmu itu; dan seorang yang berdosa tidak akan memikul dosa orang lain

Ayat ini menunjukkan bahwa Allah Swt tidak suka dan tidak meridahi kekufuran hambanya dalam masalah agama, walaupun dalam masalah "eksistensi kekafiran", Allah berkehendak atas kekufuran manusia, karena manusia memilih kekafiran. ${ }^{164}$

Kehendak dan taqdir Allah, menurut Ibnu Qayyim, tidak akan keluar dari keadilan-Nya dalam menciptakan makhluq-Nya, namun keadilan itu bukan seperti Mu'tazilah karena Allah harus menciptakan sesuatu yang bermanfa'at dan menjaga dari terjadinya bahaya, jika Allah menciptakan sebaliknya maka akan menjadi zalim. Keadilan Allah, bagi Ibnu Qayyim, difahami sebagai memposisikan sesuatu pada letaknya, dan lawan katanya adalah zalim. Pada pengertian ini semua apa yang diciptakan Allah adalah baik, dan semua yang wujud pada dasarnya adalah baik, karena kalau ia tidak baik tentu Allah tidak akan menciptakannya. Sedangkan keburukan muncul dari ketiadaan yang baik; ketiadaan dari kesabaran, ketaqwaan, dan dari semua yang baik. Allah menciptakan di alam semesta ini, dengan kehendak-Nya, berbagi sebab dan akibat, perbuatan Allah ini adalah baik dan adil. Maka kemudian Allah menurunkan syari'at tentang bagaimana manusia memperlakukan

${ }^{164}$ Ibnu I-Qayyim Al-Jawziyyah, Shifa'u I-Alil Fi Masa'ili I-Qada' Wa I-Qadar Wa l-Hikmah Wa t-Ta'lil. P.106 
ciptaan-Nya, termasuk diri manusia itu, keluarga, masyarakat, dan semua alam semesta. Dengan diturunkannya shari'at itu Allah mencintai berbagai perbuatan yang sesuai dengan syari'at yang diinginkan-Nya, dan Allah membenci ketika perbuatan manusia melanggar dan menjauh dari syari'at-Nya. ${ }^{165}$

Apa yang dilakukan manusia menurut Ibnu Taymiyyah dan Ibnu Qayyim adalah benar-benar perbuatan manusia itu sendiri secara riil bukan fiktif. Manusia menurut Ibnu Qayyim melakukan Kasb atau usaha, hanya saja usaha itu bagi Ibnu Qayyim tidak menjadikan manusia sebagai pelaku fiktif, karena Allah telah menciptakan manusia kemampuan untuk berbuat dan memilih, maka Allah sebagai pencipta perbuatan itu, dan manusia adalah pelaku riilnya. Ibnu Qayyim memberikan sebuah dalil:

$$
\text { وَأَنَّهُ هُوْ أَضْحَكَدَوَأَبْكَى }
$$

Dan Dialah yang menjadikan orang tertawa dan menangis (An-Najm:43)

Pada ayat ini tertawa dan menangis adalah perbuatan manusia secara riil, walaupun Allah yang menciptakan sebab dan akibatnya. Allah menciptakan bahwa manusia ketika menyukai sesuatu ia akan memujinya, namun jika ia membenci sesuatu maka ia akan berusaha untuk memusnahkannya. ${ }^{166}$

Dengan adanya Taqdir Allah sebelum segala sesuatu terjadi, tidak menghalangi manusia dari berusaha. Mengimani ilmu Allah

165 Ibnu I-Qayyim Al-Jawziyyah, Shifa'u I-'Alil Fi Masa'ili I-Qada' Wa I-Qadar Wa l-Hikmah Wa t-Ta'lil. P. 359-369

166 Ibnu I-Qayyim Al-Jawziyyah, Shifa'u I-'Alil Fi Masa'ili I-Qada' Wa I-Qadar Wa l-Hikmah Wa t-Ta'lil. P. 275-276 
sebelum terjadinya segala sesuatu, tidak menjadikan seseorang untuk meninggalkan shari'ah. ${ }^{167}$ Dalam sebuah hadith dikisahkan:

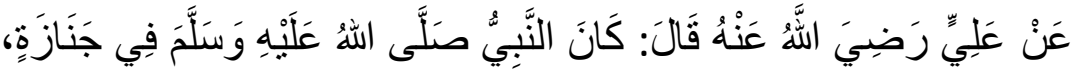

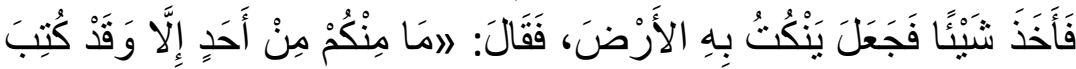

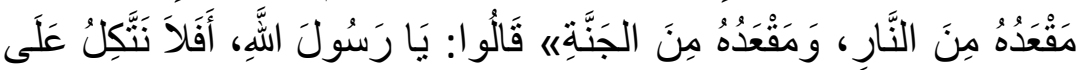

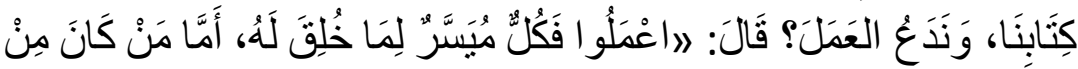

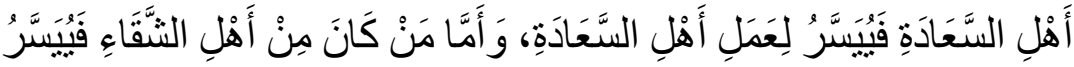

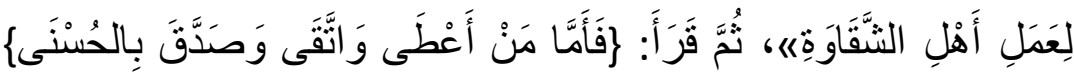

]

Dari Ali Ra: bahwa Nabi Saw dalam pemakaman, kemudian ia mengambil sesuatu dan membuat titik di bumi, dan berkata: "tidak ada satupun dari kalian kecuali telah dituliskan tempatnya di neraka atau tempatnya di surga. Sahabat bertanya: "wahai Rasulullah, bukankah cukup kita menyerahkan semuanya kepada (taqdir yang dituliskan di) kitab, dan kita tidak perlu berbuat apa-apa", Nabi bersabda: "lakukanlah karena semuanya sudah dimudahkan atas apa yang diciptakan, sedangkan ahli surga akan dimudahkan untuk melakukan perbuatan-perbuatan ahli surga, sedangkan ahli neraka, akan dimudahkan untuk melakukan perbuatan-perbuatan ahli neraka." Kemudian Nabi membaca surat Al-Layl:6.

Disini manusia tidak perlu memikirkan tentang taqdir, tentang ilmu Allah dsbg. karena ia pasti tidak akan mampu untuk mencapai itu semua. Maka seharusnya ia berusaha, berbuat, dan bekerja karena taqdir itu berdasarkan hadith tersebut masih bisa dirubah, tergantung amal usaha manusia. ${ }^{168}$

167 'Abdu I-llah bin Sulayman bin Salim Al-Ahmadi, Al-Masa'il Wa r-Rasa'il Al-Marwiyyah Min Al-Imam Ahmad Bin Hanbal Fi l-'Aqidah, 1st edn (Riyad: Daar Tayyibah, 1991). P. 22-26, 55-56

${ }^{168}$ Al-Bukhari. 6/171; Al-Jawziyyah, Shifa'u I-'Alil Fi Masa'ili I-Qada' Wa I-Qadar Wa I-Hikmah Wa t-Ta'lil. P.51-54 
Kesimpulannya, menurut Ibnu Taymiyyah dan Ibnu Qayyim bahwa perbuatan manusia itu diciptakan oleh Allah Swt, ketaatan, kekafiran, kemungkaran, kebaikan semuanya adalah ciptaan Allah dan tidak akan keluar dari kehendak Allah. Namun Allah, dengan kehendaknya terhadap agama, membenci kekufuran dan kemungkaran, namun mencintai keimanan dan keta'atan. Kemudian, walaupun perbuatan manusia itu diciptakan oleh Allah, namun perbuatan manusia secara riil adalah miliknya sendiri. Maka dalam masalah af'alu l-'ibad, Ibnu Taymiyyah dan Ibnu Qayyim menengahi perdebatan antara Jabariyyah dan Qadariyyah.

\section{Posisi Pertengahan Antara Jabariyyah dan Qadariyyah}

Masalah af'alu l-'ibad memang menjadi diskusi menarik sepanjang sejarah umat manusia. Bagi orang atheis, perbuatan manusia adalah miliknya sendiri ia bebas berkehendak dan bebas berbuat (free will fee act) karena tidak ada hubungannya antara dirinya dengan tuhan. Manusia adalah pencipta bagi perbuatannya, bahkan manusia adalah penentu bagi moralitas kebaikan dan keburukan (antrophosentris). Hal ini berbeda dengan seorang muslim yang beriman ketika ia meyakini bahwa Allah pencipta maka semua perbuatannya berkaitan dengan Allah Swt baik secara ontologis maupun etis.

Secara ontologis perbuatan manusia adalah ciptaan Allah Swt, sebagaimana yang diungkapkan oleh Al-Ash'ari, Al-Maturidi, Ibnu Taymiyyah, dan Ibnu Qayyim, karena tidak ada satupun yang keluar dari ilmu, kekuasaan, dan kehendak Allah. Atau dengan kata lain taqdir Allah meliputi semua yang ada, termasuk perbuatan manusia. Sedangkan Mu'tazilah menolak perbuatan manusia diciptakan, karena itu akan membatalkan taklif atau pembebanan shari'ah, karena dalam perintah dan larangan mengharuskan balasan 
(al-jaza' wa l-'iqab). Hal ini mengakibatkan perbuatan manusia dalam perspektif Mu'tazilah bebas dalam berbuat dan memilih.

Menjawab problem kebebasan manusia Al-Ash'ari, Al-Maturidi, Ibnu Taymiyyah, dan Ibnu Qayyim meyakini teori kasb atau usaha manusia dalam menghasilkan suatu perbuatan. Hanya saja bagi Imam Al-Ash'ari karena yang menciptakan perbuatan itu adalah Allah, maka itu adalah perbuatan Allah secara riil dan perbuatan manusia secara fiktif. Sedangkan Al-Maturidi, Ibnu Taymiyyah, dan Ibnu Qayyim meyakini bahwa manusia dengan usahanya mampu menghasilkan sebagai perbuatan manusia secara riil walaupun perbuatan itu diciptakan oleh Allah. Keempat ulama' ini meyakini bahwa yang nanti akan mendapat balasan adalah usaha manusia, berdasarkan dalil dalil dari Al-Qur'an dan Al-Hadith.

Dalam masalah af'alu l-'ibad Mu'tazilah mengambil posisi yang ekstrim dengan berpihak pada Qadariyyah. Sedangkan Al-Ash'ari, Al-Maturidi, Ibnu Taymiyyah, dan Ibnu Qayyim telah berhasil menengahi dan menyelesaikan berbagai permasalahan antara Jabariyyah dan Qadariyyah. Tentunya pengambilan posisi ke-4 ulama' itu dengan mensintesiskan berbagai ayat yang terkadang berkonotasi Jabariyah dengan ayat yang berkonotasi Qadariyyah.

\section{PENGARUH MENGIMANI QADA' DAN QADAR}

Mengimani qada' dan qadar akan menjauhkan manusia dari sifat kesyirikan, karena meyakini bahwa Allah adalah satu-satunya yang mengatur seluruh kejadian di alam semesta tanpa ada sekutu bagi-Nya. Selain itu jika keimanan ini telah menjadi worldview dalam diri seseorang maka akan memunculkan beberapa karakter sebagai bukti bahwa keimanan tersebut benar-benar ada dalam dirinya. Karakter itu diantaranya; Berusaha dan bertawakkal kepada Allah dan rido dan sabar terhadap ketetapan Allah, 


\section{Berusaha dan Bertawakkal Kepada Allah}

Seseorang yang beriman kepada qada' dan qadar harus memunculkan sikap tawakkal terhadap segala urusan yang ada di dunia. Tawakkal secara bahasa berarti menunjukkan kelemahan dan bersandar kepada yang lain, secara istilah berarti percaya kepada Allah dan melihat apa yang dimiliki manusia adalah sia-sia. Seorang yang bertawakkal meyakini bahwa Allah telah menjamin rizki dan semua permasalahannya, ia haya bergantung kepada Allah saja, dan tidak akan bersandar kepada yang lainnya. ${ }^{169}$ dikatakan dari Ali Ra:

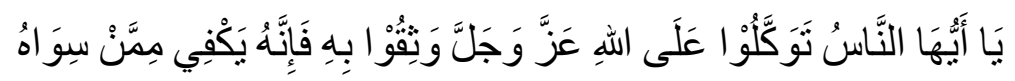

"wahai manusia bertawakkallah kepada Allah, dan berpegang teguhlah kepada-Nya karena cukup bagi kita Allah bukan selain-Nya." ${ }^{170}$

Bertawakkal bukan berarti meninggalkan dunia, orang yang bertawakkal juga harus berusaha untuk mencapai apa yang ia tuju. Ada seorang bertanya kepada Al-Marwadzi (seorang ahli figh dan ahli hadith dari madhab Hanbali hidup tahun abad ke 2-3 H) dan ia hendak melakukan perjalanan "apa yang engkau sukai seseorang membawa bekal atau bertawakkal?" ia menjawab: "ia membawa bekal kemudian bertawakkal."171 Bertawakkal bukan berarti tidak melakukan apapun atau berdiam diri saja, namun bertawakkal harus didahului dengan berusaha untuk mencapai sesuatu yang diinginkan. Seseorang jika ingin pintar maka ia harus belajar dan jika ingin kaya maka ia harus berusaha mencari harta. Semua itu harus didahului dengan usaha.

\footnotetext{
${ }^{169}$ Al-Zabidi.

170 Abu Dunya, At-Tawakkal 'ala Allah, 1st edn (Beirut: Daaru I-Basha'ir Al-Islamiyyah, 1987). P.42

171 Al-Qadi Abu Ya'la Muhammad Husain Al-Farra' Al-Hanbali, Kitabu T-Tawakkal, ed. by Yusuf binn 'Ali At-Tarif, 1st edn (Riyad: Daaru I-Mayman, 2014). P.38
} 
Bertawakkal bukan berarti memakai baju yang compang-camping, makan seadanya, rumah gubuk reyot tak terurus. Justru sebaliknya, dengan bertawakkal maka seseorang harus memiliki mimpi dan impian, ia harus bekerja; baik dengan berdagang atau memproduksi sesuatu. Al-Mazini Basyar bin Al-Harith berkata: "seorang yang bertawakkal tidak bertawakkal kepada Allah untuk dicukupkan, kalaulah perak ini menyenangkan di kalbu orang yang bertawakkal, ia akan memohon kepada Allah dengan penyesalan dan taubat, seorang yang bertawakkal akan menempatkan di dalam kalbunya cukup hanya dengan Allah dan percaya kepada Allah atas apa yang sudah dipastikan." ${ }^{172}$

Perintah untuk bertawakkkal adalah perintah yang progresif, bukan statis, seorang hamba di satu sisi diperintahkan untuk bermimpi dan maju, dan di sisi yang lain dalam kemajuannya ia harus menghubungkan berbagai usahanya, daya upayanya hanya kepada Allah Swt. Walaupun ia bekerja untuk memperoleh rezeki, atau belajar untuk memperoleh ilmu, namun ia yakin bahwa yang memberikannya rezeki bukan pekerjaan itu, yang memberikannya ilmu bukan dari buku-buku, tapi itu semua pemberian Allah Swt.

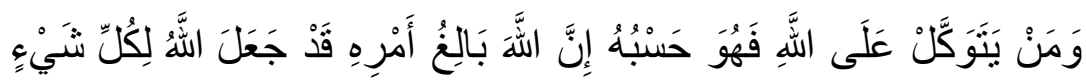

قََْْرَ

Barangsiapa yang bertawakkal kepada Allah niscaya Allah akan mencukupkan (keperluan)nya. Sesungguhnya Allah melaksanakan urusan yang (dikehendaki)Nya. Sesungguhnya Allah telah Mengadakan ketentuan bagi tiap-tiap sesuatu. (At-Thalaq:3)

${ }^{172}$ Abu Bakar Ahmad bin Muhammad bin Harun Al-Khallali, Al-Hathu 'ala t-Tijarah Wa s-Shina'ah Wa l-'Aamal Wa I-Inkar 'Ala Man Yadda'i At-Tawakkal Fii Tarki l-'Amal Wa l-Hujjah 'Alayhim Fii Dhalika, 1st edn (Riyad: Daaru l-'Ashimah). P.179 


\section{Ridha dan Sabar Terhadap Ketetapan Allah}

Seorang hamba wajib untuk ridha dengan taqdir Allah Swt atas dirinya tentang bagaimana ia diciptakan, tentang baik dan buruknya. Maka Imam Jurjani menyebutkan makna dari ridha adalah "senangnya kalbu dengan ketetapan yang pahit." ${ }^{173}$ Ustadz Abu Ali Daqqaq menyebutkan "rida kepada taqdir bukan berarti tidak merasakan bencana, namun rida adalah tidak menolak ketetapan atau taqdir tersebut." Imam Qusyairi menjelaskan bahwa kita hanya boleh meridahi taqdir Allah Swt yang diperintahkan untuk diridahi, ada ketetapan-ketetapan yang dilarang untuk ridha kepadanya, seperti kekufuran, kemaksiatan, dsbg. ${ }^{174}$

Berbagai problem yang dirasakan oleh manusia dalam hidupnya sesungguhnya telah dipilihkan oleh Allah Swt bagi tiap-tiap manusia. Sehingga ketika ada musibah yang mengenainya ia akan bersabar dengan keadaannya. Ibnu 'Atha' Ra sebagaimana dikutip oleh At-Tusi, "Ridha adalah ketika kalbu melihat kepada pilihan yang dipilihkan Allah untuk hambanya, dan apa yang dipilihkan baginya adalah sesuatu yang paling utama, kemudian ia rela dengannya dan meninggalkan segala amarah." ${ }^{175}$ Kemudian riwayat dari Rabi'ah Al-'Adawiyyah dikutip oleh Al-Qusyairi, Ridha adalah "ketika seseorang menjalani musibah sebagaimana ia menjalani kenikmatan."176

Tawakkal, ridha, dan sabar memiliki keterkaitan. Seseorang yang bertawakkal mengharuskan dirinya untuk ridha dan bersabar, tidak boleh seseorang bersabar, namun ia tidak ridha dan bertawakkal. Penjelasan dalam Al-Qur'an mengenai tawakkal, ridha,

\footnotetext{
173 Al-Jurjani. P.116

${ }^{174}$ Al-Qushairi. P.339

175 Al-Tusi. P.80

${ }^{176}$ Al-Qushairi. P.338
} 
dan sabar selalu mengharuskan adanya usaha. Tawakkal, rida dan sabar bukan berarti berdiam diri saja, tapi ia adalah nilai akhlaq yang mengharuskan seseorang untuk berjuang dan berusaha baik untuk dunianya dan agamanya. Imam Al-Qusyari membagi sabar menjadi 2: Pertama,sabar terhadap sesuatu yang diusahakan, yakni dalam mengusahakan agar dirinya taat kepada Allah dan meninggalkan larangan-Nya, kemudian sabar untuk mencapai tujuan-tujuan yang baik bagi hidupnya. Kedua, sabar terhadap sesuatu yang tidak diusahakan, atau hal tersebut adalah pemberian Allah, seperti keadaan fisik, harta, keluarga, dsbg. ${ }^{177}$

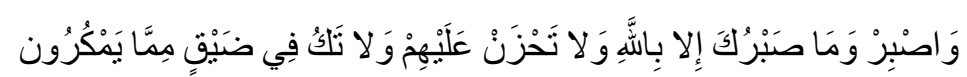

Bersabarlah (hai Muhammad) dan Tiadalah kesabaranmu itu melainkan dengan pertolongan Allah dan janganlah kamu bersedih hati terhadap (kekafiran) mereka dan janganlah kamu bersempit dada terhadap apa yang mereka tipu dayakan. (An-Nahl: 127)

${ }^{177}$ Al-Qushairi. P.324 


\section{EPILOG}

\section{MENCAPAI KEBAHAGIAAN DENGAN MENDIDIK AKHLAQ}

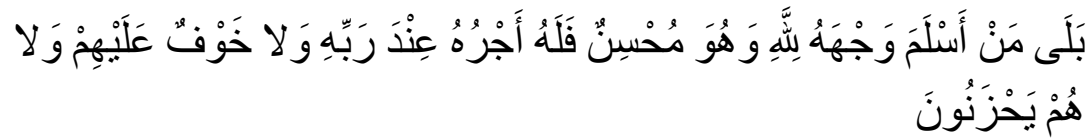

Barangsiapa yang menyerahkan diri kepada Allah dan ia berbuat kebajikan, Maka baginya pahala pada sisi Tuhannya dan tidak ada ketakutan terhadap mereka dan mereka juga tidak bersedih hati. (Al-Baqarah:112)

Semua orang pasti bertujuan untuk menjadi bahagia dalam hidupnya. Setiap perbuatan, langkah yang dilakukan tidak lain adalah bertujuan untuk mencapai kebahagiaan itu sendiri. Adalah absurd ketika seseorang melakukan sesuatu dengan tujuan untuk menderita. Ketika ditanyakan kepada seorang pemabuk, "mengapa engkau suka minum-minum?" ia berkata "aku bahagia dengan itu", banyak dari para pemabuk, pezina, dan berbagai pelaku kemaksiatan bahagia dengan perilakunya maka mereka melakukan itu. Pada tataran ini kebahagiaan telah direduksi menjadi sama dengan kenikmatan. Itu adalah pandangan hedonisme dan utilitarianisme. ${ }^{178}$

kelompok utilitarianisme yang dipelopori oleh Bentham mengatakan bahwa sesuatu disebut baik ketika membawa manusia pada kebahagiaan. Kebaikan itu diperoleh bukan pada perbuatan itu sendiri, namun pada konsekwensinya. Misalkan: jika membunuh mempu membawa manusia pada kebahagiaan, maka membunuh menjadi baik. Menurut Bentham kebahagiaan adalah ketika manusia memperoleh kenikmatan dan hilang darinya penderitaan. Kebahagiaan dalam perspektif utilitarianisme sangat sempit, padahal kebahagiaan lebih dari sekedar kenikmatan dan penderitaan. Juga

${ }^{178}$ Honderich. P.936, 
sangat berbahaya karena akan memoralkan berbagai tindakan amoral demi mencapai kenikmatan. ${ }^{179}$

Kita lihat bagaimana Aristotle dalam "The Nicomachean Ethics" ${ }^{180}$ berbicara tentang kebahagiaan. Kebahagiaan menurutnya bukan hanya sekedar merasakan senang. Kebahagiaan menurutnya adalah akhir dari semua yang baik, tidak ada orang yang memilih profesi apapun, kecuali tujuan akhirnya adalah untuk menjadi bahagia. Seorang guru, polisi, artis dsbg memilih profesinya masing-masing tidak lain adalah untuk mencari kebahagiaan. Kebahagiaan menurut Aristotle adalah aktifitas jiwa yang berkesesuaian dengan kepandaian (virtue) atau keunggulan (excellence) seseorang. Maksudnya adalah jika ada seorang yang belajar melukis dan bersungguh-sungguh menekuni profesinya akan sangat bahagia ketika ia menjadi seorang pelukis. Setiap orang menurut Aristotle dapat menjadi benar-benar bahagia ketika aktifitas jiwanya yang terproyeksikan dalam kegiataan praktisnya berkesesuaian dengan minat dan bakatnya.

Keunggulan atau excellence dibagi menjadi dua pertama, keunggulan intelektual, kedua, keunggulan moral. Untuk mencapai keunggulan intelektual dapat dicapai dengan berlatih mengikuti intruksi-intruksi tertentu, hal ini membutuhkan waktu dan pengalaman. Sedangkan keunggulan moral dicapai dengan melatih diri sehingga terciptalah kebiasaan/ habit. Menurut Aristotle pencapaian kebahagiaan dapat dilakukan dengan melatih potensi kemampuan untuk mencapai kepandaian (virtue) atau keunggulan (excellence) tertentu. Setelah melatih potensinya, maka orang tersebut akan dapat mencapai tujuan kepandaian dan keunggulan

179 Stephen Law, Philosophy: History, Ideas, Theories, Who's Who, How to Think, 1st edn (London: Dorling Kindersley, 2007). P.102

${ }^{180}$ Aristotle, The Nicomachean Ethics, ed. by F.H. Peters, 4th edn (London: Kegan Paul, Trench, Trubner \& co., Itd., 1891). 
yang diinginkan. Kemudian pencapaian ini akan menciptakan kepuasan serta kesenangan (pleasure) dan cinta terhadap bidangnya (affection) dalam jiwa. Ketika jiwa seseorang mencapai kepuasan, kesenangan, dan cinta inilah yang disebut dengan kebahagiaan.

\section{KEBAHAGIAAN MENURUT FILOSOF MUSLIM}

Para Filosof Muslim dalam menafsirkan kebahagiaan berbeda antara satu dengan yang lainnya. Walaupun kemudian pendapat mereka tentang kebahagiaan terpengaruh dari pemikiran Yunani; Socrates, Plato, dan Aristotle. Pada pembahasan ini akan dijelaskan 3 pemikir muslim yakni Al-Farabi, Ibnu Sina, dan Ibnu Miskawaih dalam memandang kebahagiaan melalui karya-karya mereka.

\section{Al-Farabi}

Kebahagiaan menurut Al-Farabi sebagaimana Aristotle, adalah kebaikan mutlak dan semua hal yang bermanfaat dan membawa kepada kebahagiaan adalah kebaikan, karena ia bermanfaat bagi kebahagiaan. Sedangkan berbagai hal yang menjauhkan manusia dari kebahagiaan adalah keburukan secara mutlak. Kemudian bagaimana kebahagiaan itu muncul? Menurut Al-Farabi, manusia akan bahagia ketika jiwanya menuju pada kesempurnaan eksistensi tanpa membutuhkan materi, atau ketika manusia mengetahui hal-hal yang al-ma'qulat (hal-hal yang bersifat rasional, bukan material). ${ }^{181}$

Kebahagiaan dapat dicapai dengan kehendak manusia menggunakan 5 potensi jiwa yakni: potensi rasional teoritis, rasional

\footnotetext{
${ }^{181}$ Abu Nashr Al-Farabi, Araa'u Ahli I-Madinah Al-Fadilah Wa Madhadatuha, ed. by Ali bu Mulham, 1st edn (Beirut: Daar wa Maktabah Al-Hilal, 1995). P.100
} 
praktis, dorongan-dorongan, imajinasi, dan indera. Manusia mengetahui dan memikirkan kebahagiaan dengan akalnya dan hal-hal untuk mencapai kebahagiaan, hal itu akan menghasilkan dorongan-dorongan dalam jiwanya agar ia berusaha untuk mencapai kebahagiaan itu. Kemudian pencapaian itu dibantu dengan potensi imajinasi dan potensi inderawi dalam mewujudkan kebahagiaan tersebut. Sedangkan keburukan terjadi karena manusia mencapai kebahagiaan hanya dengan potensi imajinasi dan potensi inderawi saja. Padahal keduanya tidak mampu untuk mengetahui kebahagiaan. Maka terkadang manusia mengira suatu hal adalah baik, namun setelah ia tidak menemukan kebahagiaan di dalamnya, potensi rasionalnya akan menuntunnya untuk mencari kebahagiaan. Maka menurut Al-Farabi semua potensi manusia, harus tunduk pada potensi rasional teoritisnya (al-quwwah an-natiqah an-nadhariyyah) sehingga ia dapat mencapai pada kebaikan dan kebahagiaan. ${ }^{182}$

\section{Ibnu Sina}

Dimulai dari penjelasan Ibnu Sina dalam kitab 'Uyunu I-Hikmah tentang definisi kebahagiaan (as-sa'adah):

"Kebahagiaan adalah terputusnya fikiran dari memikirkan hal-hal yang dapat ditangkap inderawi, dan berhenti pada keagungan Al-Haqqu l-Awwal (atau Kebenaran Pertama maksudnya adalah Allah Swt), kemudian mengkajinya secara rasional, kemudian mengungkapkan yang universal dari padanya, agar yang universal dapat tergambarkan dalam jiwa rasional dan mengamatinya, kemudian ia menyaksikan Allah yang haqq - tanpa ada kerusakan dan putusan - dengan kesaksian yang rasional. ${ }^{183}$

Penjelasan dari ungkapan ini bahwa kebahagiaan yang sebenarnya dapat dicapai dengan menekankan pada akal rasional, akal rasional

\footnotetext{
${ }^{182}$ Abu Nashr Al-Farabi, Kitabu S-Siyasah Al-Madinah, ed. by Ali bu Mulham (Beirut: Daar wa Maktabah Al-Hilal). P.79-84

${ }^{183}$ Ibnu Sina Avicenna, 'Uyunu I-Hikmah, ed. by Abdu r-Rahman Al-Badawi, 2nd edn (Beirut: Daaru I-Qalam, 1980). P.60
} 
dapat dioptimalkan ketika manusia memutuskan fikiran manusia dari berbagai hal yang materil dan memfokuskan fikirannya pada hal-hal yang universal atau yang ma'qulat kemudian fikirannya ditujukan hanya untuk Allah Swt.

Menurut ibnu Sina dalam kitab Al-Isharat wa t-Tanbihat, kenikmatan adalah pencapaian sesuatu yang sempurna atau baik, dan buruk adalah pencapaian yang rusak atau buruk. Ibnu Sina menekankan bahwa kenikmatan akal-rasional lebih baik daripada kenikmatan tubuh yang bersifat inderawi. Kenikmatan tubuh terkait dengan hal-hal yang nampak dan materil, ia tercampur antara yang jelas dan yang samar-samar, dan hanya terbatas pada jenis yang sedikit. Hal ini berbeda dengan kenikmatan akal, seseorang bagi Ibnu Sina akan merasakan kenikmatan akal ketika ia akan berusaha untuk mencapai Allah Swt, tentunya untuk mengetahui dhat Allah adalah tidak mungkin. Namun manusia akan memperoleh kenikmatan dengan memikirkan bentuk sebab-sebab yang membawanya kepada mengenal Allah. Dan seseorang ketika melakukan itu maka ia akan menemukan kesempurnaan dan akan mendapatkan kenikmatan akal. $^{184}$

Nashiru d-Din At-Tusi dalam Sharahnya terhadap kitab Al-Isharat wa Tanbihat menyebutkan bahwa yang menjadikan kenikmatan akal lebih sempurna karena; Pertama,akal mampu membawa manusia pada hakikat segala sesuatu, kemudian manusia akan memikirkan hakikat segala sesuatu melalui aksiden-aksidennya. Sedangkan indera hanya mampu mengetahui bentuk fisik yang hadir dari sesuatu, bahkan sering tercampur antara pengetahuan tentang satu hal dengan yang lainnya. Kedua, jumlah dari hal-hal yang dapat diketahui tidak akan pernah habis hal ini karena jenis-jenis (genus)

\footnotetext{
184 Ibnu Sina Avicenna and Abu Nasr At-Tusi, Al-Isharat Wa At-Tanbihat Vol IV, Fi t-Tasawuf, ed. by Sulayman Dunya, 2nd edn (Mesir: Daaru I-Ma'arif, 1968). P.11-16
} 
dari semua eksistensi tidak akan pernah habis, dan yang mampu mengetahui semuanya adalah akal. Sedangkan indera sangat terbatas hanya mampu mengetahui hal-hal yang terlihat atau terasa di panca indera. Sehingga kenikmatan akal lebih banyak dan lebih sempurna, sehingga ia lebih sempurna daripada kenikmatan inderawi. $^{185}$

Kemudian Ibnu Sina menjelaskan pandangan tentang tasawuf, tentang al-'arifuna billah atau orang-orang yang mengenal Allah Swt. Mereka adalah orang yang memutuskan dirinya dari kehidupan dunia dan hanya fokus untuk mencapai alam yang suci dan kebahagiaan, kemudian akan terukir kesempurnaan dan kenikmatan tertinggi. Namun bukan berarti manusia itu mati, ia tetap masih hidup, jiwanya masih ada dalam tubuh, namun ia terbenam dalam meneliti berbagai hal yang mendekatkannya kepada Allah, dan ia menikmati itu dan berbahagia dengan itu. ${ }^{186}$

\section{Ibnu Miskawaih}

Wacana kebahagiaan diutarakan oleh Ibnu Miskawaih dalam kitab Tahdhibu l-Akhlaq, ia berpendapat sebagaimana para filosof sebelumnya; Aristotle, Al-Farabi, dan Ibnu Sina, juga berpendapat bahwa kebahagiaan adalah kebaikan mutlak. Namun apa yang disebut dengan kebaikan itu? Hal ini menjadi penting karena Al-Farabi dan Ibnu Sina, dalam mencapai kebahagiaan cenderung meremehkan peran materi di dalamnya. Pendapat yang mengatakan bahwa kebahagiaan hanya dapat diperoleh dengan pemenuhan kesempurnaan jiwa dan akal adalah pendapat Phytagoras, Hippocrates, dan Plato. Bagi kelompok ini manusia akan mendapatkan kebahagiaan setelah memisahkan diri dari badan dan semua hal yang materil, karena menurut mereka materi adalah kotor.

\footnotetext{
${ }^{185}$ Avicenna and At-Tusi. P.17

${ }^{186}$ Avicenna and At-Tusi. P.32-33
} 
Bagi mereka ketika manusia masih bersama badan, dan fikirannya masih terfokus pada badan maka ia tidak akan bahagia secara mutlak. Maka bagi pendapat ini manusia harus memfokuskan fikirannya hanya untuk memenuhi kesempurnaan jiwanya saja, walaupun saat itu jiwanya masih ada dalam tubuh. ${ }^{187}$

Ibnu Miskawaih mengkritik pendapat ini, menurutnya manusia tidak mungkin mampu mencapai kebahagiaan tertinggi selama hidupnya jika ia tidak mampu membahagiakan tubuhnya; kebahagiaan hanya bisa dicapai dengan memenuhi kebaikan tubuh dan jiwa secara bersamaan. la bertolak belakang dengan pendapat Al-Farabi dan Ibnu Sina dalam memahami tubuh manusia, menurutnya tubuh itu tidak kotor, tapi ia adalah baik. Memang manusia memiliki keunggulan ruhani yang sama dengan malaikat, namun manusia juga memiliki keunggulan jasmani yang sama dengan hewan, kedua-duanya adalah baik. Maka untuk mencapai kebaikan yang sempurna manusia harus menggapai kebaikan jasmani yang ada di alam ini agar dapat mencapai kesempurnaan yang abadi di akhirat kelak, bersama para malaikat dan ruh yang suci. ${ }^{188}$

Kemudian apakah mungkin manusia dapat mencapai pada hikmah atau kebijaksanaan? Mengenai hal ini Ibnu Miskawaih menyebutkan bahwa ketika manusia telah merasakan kebahagiaan dalam tubuhnya maka ia akan mampu fokus mengkaji dan meneliti berbagai hal, termasuk hal-hal yang materil dan non-materil, tujuannya adalah untuk mengetahui tanda-tanda kekuasaan Allah dan kebijaksanaan yang sempurna. Manusia harus mengoptimalkan baik kemampuan jasmaninya maupun ruhaninya untuk dapat mencapai kesempurnaan tersebut. Manusia seperti ini menurut Ibnu Miskawaih telah mencapai tingkatan tertinggi dari kebaikan, ia akan

\footnotetext{
${ }^{187}$ Miskawaih, Tahdhibu L-Akhlaq. P.311-312

${ }^{188}$ Miskawaih, Tahdhibu L-Akhlaq. p.314-315
} 
menggunakan semua kebaikan dunia baik yang ada dalam dirinya maupun di luar dirinya sebagai hal yang penting dan dibutuhkan bagi tubuhnya, ia terikat dengan kehendak Allah atas dirinya. Dengan kebaikan materil di dunia ia melakukan perintah Allah dan selalu mendekatkan diri kepada-Nya. Kemudian ia tidak akan mengikuti syahwatnya yang hina dan tidak akan tertipu dengan fatamorgana yang sekilas terlihat baik ternyata buruk, ia sadar bahwa keburukan itu akan menghalanginya untuk bahagia. ${ }^{189}$

Bagi Ibnu Miskawaih sama dengan para filosof sebelumnya, kenikmatan akal merupakan kenikmatan tertinggi, namun ia lebih realistis dari para pendahulunya, bahwa kenikmatan itu harus didukung dengan kenikmatan lain yang juga baik tentunya pada porsi yang adil antara. la mengutip pendapat Aristotle:

"sesungguhnya kebahagiaan transendental (as-sa'adah al-ilahiyyah), sebagaimana yang kami sebutkan bagian dari kehormatan, menjalaninya adalah kenikmatan dan kehormatan yang tertinggi, sesungguhnya ia membutuhkan pada kebahagiaan lainnya yang bersifat inderawi, kemudian ia akan menampakkan kebahagiaan transendental sehingga ia tidak tersembunyi. Hal ini seperti orang yang unggul ketika ia tidur maka tidak akan kelihatan perbuatannya, ketika itu tidak akan terlihat perbedaan antara ia dengan manusia lainnya." ${ }^{190}$

Orang yang mengalami kenikmatan akal adalah orang yang berbahagia, maka manusia harus selalu menjaganya agar selalu berada pada keadaan itu. Untuk menjaga akal agar selalu bahagia maka perlu adanya kesabaran dan manusia harus melatih dirinya, agar jiwanya selalu siap menghadapi musibah. Ketika ia mendapatkan musibah ia tidak sedih, bingung dsbg, ia mampu mengontrol dirinya sehingga tidak berpindah dari keadaan bahagia. Sebagaimana Nabi Ayyub As setika diberikan cobaan yang luar biasa,

\footnotetext{
${ }^{189}$ Miskawaih, Tahdhibu L-Akhlaq. p.315-316

${ }^{190}$ Miskawaih, Tahdhibu L-Akhlaq. p. 323
} 
ia tidak berpindah dari keadaan bahagia, ia tidak sedih ataupun bingung. ${ }^{191}$

Kebahagiaan akal dapat menjadi watak seseorang ketika ia mampu untuk melatihnya. Hal ini karena nafsu akan selalu mendorong pemenuhan kebahagiaan tubuh, jika tidak dikontrol dengan akal, maka ia akan berlebihan. Maka ketika manusia mampu melatih jiwanya, ia akan merasakan kebaikan, kebaikan itu akan berlawanan dengan nafsu. Kemudian Ibnu Miskawaih menengahi bahwa manusia pada mulanya butuh pendidikan dari orang tuanya, kemudian ia butuh kepada syari'at Allah dan agama yang lurus, yaitu Islam. Ibnu Miskawaih sebagai seorang muslim meyakini bahwa kebaikan-kebaikan yang dicapai oleh manusia di dunia ini harus didasarkan pada syari'at, hal ini akan membawanya menuju akhirat; ialah keadaan ketika jiwa manusia terlepas dari dunia untuk bertemu dengan Allah di akhirat. ${ }^{192}$

Ibnu Miskawaih merubah worldview para filosof Yunani yang tidak memiliki konsep surga dan neraka. la memaparkan bahwa Aristotle sendiri masih ragu tentang apakah manusia mampu mencapai kebahagiaan paripurna di dunia, karena Aristotle sendiri meyakini bahwa jiwa manusia itu bersifat kekal setelah ia mati, jiwa akan berpindah dari satu keadaan kelainnya. Maka pasti ada kehidupan setelah mati yakni tempat jiwa mendapatkan kebahagiaan tertinggi, namun Aristotle tidak berani memastikan hal tersebut. ${ }^{193}$ Sedangkan dalam Islam jelas sekali yaitu mereka akan masuk ke akhirat, sebagaimana deskripsi Al-Qur'an, bahwa disana ada orang yang bahagia dan sengsara:

\footnotetext{
${ }^{191}$ Miskawaih, Tahdhibu L-Akhlaq. p. 324

192 Miskawaih, Tahdhibu L-Akhlaq. p. 328-329

${ }^{193}$ Miskawaih, Tahdhibu L-Akhlaq. p. 325-327
} 


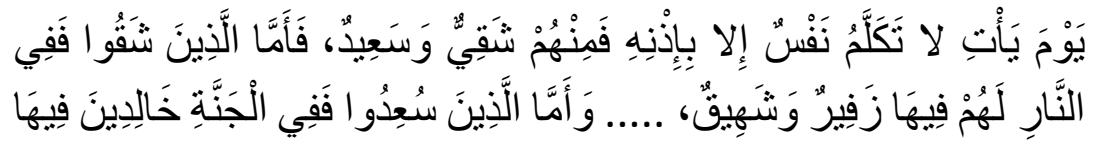

Ketika datang hari itu, tidak ada yang berbicara, kecuali dengan izin-Nya; Maka di antara mereka ada yang celaka dan ada yang berbahagia. Adapun orang-orang yang celaka, Maka tempatnya di dalam neraka, di dalamnya mereka mengeluarkan dan menarik nafas ...... Adapun orang-orang yang berbahagia, Maka tempatnya di dalam surga, mereka kekal di dalamnya ..... (Huud:105-108)

\section{MUJAHADAH DAN RIYADAH NAFS}

Seseorang yang ingin menjadikan akhlaqnya baik maka ia harus melatih akhlaqnya sehingga akhlaqnya akan sesuai dengan yang diinginkannya. Menurut Aristotle, Seseorang yang ingin menjadi pemberani, maka ia harus meredam rasa takutnya dan sikap pengecut dalam dirinya. Sifat pemberani ini tidak spontan muncul begitu saja, namun ia harus dengan berlatih sehingga muncul sifat tertentu dalam dirinya, hingga pada level menjadi kebiasaan (habit). Oleh karenanya bagi Aristotle keunggulan akhlaq terletak pada bagaimana manusia melatih panca indera, akal, dan kebiasaannya. Seorang yang pengecut harus berjuang melawan ketakutannya untuk menjadi pemberani, seorang pemarah pun akan berusaha meredam rasa amarah untuk dapat lebih sabar. Dalam hal ini Aristotle mendefinisikan bahwa akhlaq yang unggul muncul dari proses berlatih sehingga akhlaq manusia mampu berada pada posisi yang pertengahan. Ketika manusia telah mampu melatih dirinya dan memperoleh akhlaq yang unggul, menurut Aristotle, itulah kebahagiaan yang sebenarnya. 
Dalam Islam "melatih jiwa" bisa diartikan mujahadah atau riyadah nafs. Mujahadah sendiri berarti melawan jiwa amarah (nafs amarah bi s-suu') dengan sulitnya, untuk mencapai keadaan jiwa yang sesuai dengan syari'at. ${ }^{194}$ Sedangkan riyadah adalah pensucian akhlaq dalam jiwa dari berbagai dorongan-dorongan hawa nafsu. ${ }^{195}$ Dari definisi di atas menunjukkan bahwa keduanya memilki makna yang sama, juga memiliki tujuan yang sama, sebagaimana yang disebutkan oleh kaum sufi, adalah untuk fana' yaitu mengkosongkan jiwa dari akhlaq yang buruk, dan baqa' adalah mengisi jiwa dengan sifat-sifat yang terpuji.

Untuk mencapai akhlaq yang terpuji, Abu Nashr Sarraj At-Tusi ${ }^{196}$ menyebutkan bahwa kaum sufi memiliki maqamat atau kedudukan hamba bagi Allah ketika ia melakukan praktek pensucian jiwa. Maqamat itu yang pertama adalah taubah; yaitu meninggalkan segala sesuatu yang dibenci ilmu syari'at untuk mencapai kepada sesuatu yang dipuji ilmu syari'at. Kemudian wara' yaitu meninggalkan berbagai macam hal yang syubhat keharaman dan kehalalannya. Kemudian zuhud yaitu sikap meninggalkan cinta dunia. Yaitu tidak memikirkan tentang harta, kedudukan, jabatan, dsbg. kemudian faqr atau kefakiran, yaitu bersikap tidak memiliki apa-apa, dan tidak meminta jika tidak memiliki apa-apa, atau ada yang jika diberi akan diambil, atau meminta hanya ketika sudah tidak memiliki apa-apa lagi. Kemudian sabar, yaitu sabar dari berbagai hal yang dibenci syari'at, sabar melaksanakan syari'at, dan selalu sabar walaupun diterpa berbagai masalah, ujian, dan cobaan. Kemudian tawakkal menurut Abu Turab An-Nakhshabi adalah mendidik tubuh dalam ibadah, mengkaitkan qalbu dalam penghambaan, bersifat tenang dalam kecukupan, jika diberi ia bersyukur, jika ada yang

\footnotetext{
${ }^{194}$ Al-Jurjani. P. 216

195 Al-Jurjani. P. 119

${ }^{196}$ Al-Tusi. P.66-104
} 
merintangi ia bersabar, karena ia yakin dengan taqdir. Kemudian ridha yaitu sebagaimana yang sudah dijelaskan, tetapnya qalbu dengan pahitnya taqdir.

Maqamat tersebut jika dilihat maka semuanya bertujuan untuk mengontrol diri manusia. Diawali dari taubah sebagai bentuk konsekwensi diri untuk menghindari dari hal-hal yang dibenci atau diharamkan. Maka untuk menyempurnakan taubatnya maka manusia harus berperilaku faqr, wara' dan zuhud, karena dengan ketiganya manusia tidak akan terjerumus dalam kesesatan dan keharaman, juga akan menjaga dirinya agar tidak lalai untuk memikirkan dan beribadah kepada Allah. Selanjutnya dengan sabar, tawakkal, dan ridha seseorang mampu mengontrol keadaan jiwanya agar selalu berada pada keadaan yang tenang dan menekan keadaan jiwanya dari mengikuti syahwat.

Seseorang dengan menjalani taubah, wara', zuhud, faqr, sabar, tawakkal, dan rido akan mencapai keadaan-keadaan yang tiba-tiba muncul dalam jiwa (ahwal). Keadaan itu akan selalu berubah dari keadaan yang satu kelainnya. ${ }^{197}$ Terkadang seseorang yang menjalani maqamat tersebut tiba-tiba muncul perasaan bahwa dirinya sedang diawasi oleh Allah Swt, sehingga ia akan lebih berhati-hati dalam perbuatannya. Terkadang ia merasa dekat (qurb),

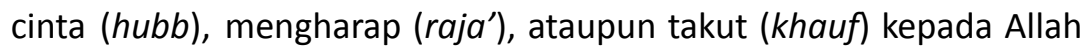
Swt. Terkadang cinta yang dirasakan sangat meluap-luap bahkan ingin bertemu dengan Allah (shawq). Terkadang ia merasakan ketenangan sebagaimana yang diisyaratkan dalam Al-Qur'an dengan an-nafs al-mutma'innah atau jiwa yang tenang. Terkadang juga ketika ia melatih dirinya menemukan dirinya seolah-olah melihat Allah

\footnotetext{
197 William James, The Varieties of Religious Experience a Study in Human Nature (New York: The Modern Library, 1902).
} 
(mushahadah) hingga pada akhirnya orang tersebut akan sampai pada keyakinan (yaqin).

\section{MENJAGA KESEHATAN JIWA}

Jiwa dan tubuh memiliki koneksi yang kuat. Tubuh akan menunjukkan keadaan jiwa, ketika manusia marah yang teramat biasanya mukanya akan memerah, begitu pula ketika ia merasa malu. Namun bedanya, ketika marah biasanya diikuti dengan mata memerah dan melotot, dan ketika malu biasanya pipinya yang memerah. Atas dasar ini Ibnu Miskawaih menyebutkan bahwa penyakit yang dialami tubuh memiliki hubungannya dengan penyakit yang ada dalam jiwa. Menurutnya ketika orang sakit dalam jiwanya, seperti saat terkena amarah yang berlebih atau sedih yang merundung, hal ini akan mempengaruhi keadaan tubuh. Maka manusia perlu menjaga kesehatan jiwanya, karena kesehatan tubuh terletak pada kondisi jiwanya. ${ }^{198}$

Ibnu Miskawaih memberikan beberapa nasihat tentang beberapa hal yang harus dijaga agar jiwa selalu sehat. Manusia jika ia ingin menjaga kesehatan jiwanya maka ia harus:

Pertama, Berteman dengan orang-orang yang baik, dan menjauhi orang-orang yang berwatak buruk, karena teman sangat mempengaruhi akhlaq manusia.

Kedua, Tidak boleh meremehkan akal, hingga hilang darinya akal. la perlu untuk terus berfikir dan belajar, tidak boleh ia lalai atas itu, karena jika ia berhenti dari berfikir dan belajar akan menyebabkan fikirannya akan berhenti.

${ }^{198}$ Miskawaih, Tahdhibu L-Akhlaq. p.394-395 
Ketiga, Tidak boleh menuruti syahwatnya dan amarahnya, ia harus mampu berusaha mengendalikan syahwat dan amarah sehingga berada pada posisi yang adil.

Keempat, Memikirkan tentang berbagai tingkah laku yang keluar dari dirinya, dan berusaha agar perbuatannya selalu baik.

Kelima, Mengetahui kekurangan dirinya, caranya agar ia mencari kawan yang baik dan memintanya untuk menyebutkannya berbagai keburukan dirinya, hingga ia meninggalkannya dan menyembuhkan dirinya. ${ }^{199}$

\section{MENYEMBUHKAN JIWA YANG SAKIT}

Bagaimanakah jiwa seseorang disebut sakit? Dalam hal ini menurut Ibnu Miskawaih jiwa yang sakit adalah ketika jiwa manusia tidak berada pada porsi yang seharusnya, bisa jadi kelebihan ataupun kekurangan. Sebagaimana yang sudah dijelaskan, ketika potensi dalam diri manusia tidak terkontrol atau tidak berfungsi akan menyebabkan jiwanya sakit, dan ketika dapat dikontrol pada keadaan pertengahan dan moderat maka jiwanya sehat. Atau dengan kata lain, jiwa yang sehat akan menghasilkan akhlaq yang baik, sedangkan jiwa yang sakit akan menghasilkan akhlaq yang buruk. Misalkan saja ketika seseorang tidak mampu mengontrol potensi amarahnya, maka ia akan menjadi pribadi yang pendendam, suka marah-marah, nekad, atau jika kurang, maka ia akan menjadi orang yang pengecut. Baik kelebihan potensi amarah ataupun kekurangan adalah hal yang buruk. ${ }^{200}$

${ }^{199}$ Miskawaih, Tahdhibu L-Akhlaq. p.306-407
${ }^{200}$ Miskawaih, Tahdhibu L-Akhlaq. p.410-412 
Ibnu Miskawaih menyebutkan beberapa jenis penyakit jiwa diantaranya adalah penyakit takut mati dan kesedihan. Munculnya penyakit itu tidak lain disebabkan oleh kurangnya ilmu atau ilmunya salah terhadap hal tersebut. Sebagaimana sebab munculnya penyakit takut mati, diantaranya adalah karena orang tersebut tidak tahu hakikat kematian, atau ia mengira bahwa kematian adalah penderitaan, atau tidak tahu apa yang terjadi setelah mati, atau sedih jika ia harus meninggalkan harta di dunia. Orang seperti ini harus diberi pengetahuan dan pemahaman tentang hakikat kematian yang sebenarnya bahwa kematian hanyalah perpisahan antara jiwa dan tubuh. Tubuh akan musnah sedangkan jiwa akan tetap kekal, Jiwa tidak akan merasakan sakit, karena rasa sakit hanyalah untuk orang yang hidup. Kemudian setiap orang harus memiliki pengetahuan bahwa ketika mati nanti ia tidak akan sirna begitu saja, namun ia akan masuk kealam akhirat. Sehingga ia akan menghindari berbagai perbuatan dosa yang akan menjerumuskannya kedalam dosa. Kemudian setiap orang harus tahu bahwa harta yang dimilikinya tidak kekal dan abadi, namun semuanya itu fana, kenikmatan yang abadi dan kekal dapat diraih nanti di akhirat. ${ }^{201}$

Sebab dari penyakit kesedihan juga sama, yaitu karena kurangnya ilmu atau ilmunya salah. Hakikat kesedihan adalah penyakit jiwa karena manusia kehilangan apa yang ia cintai, atau tidak mampu memperoleh apa yang ia inginkan. Padahal jika manusia tahu bahwa semua apa yang ada di dunia ini tidaklah abadi, keabadian ada di akhirat. Jika seseorang tahu akan hal itu maka ia tidak akan tamak dengan kehidupan dunia dan tidak akan sedih atas kehilangan apa yang ia inginkan. ${ }^{202}$ Orang yang sedih karena kehilangan dan tamak terhadap dunia, disebutkan dalam Al-Qur'an,

${ }^{201}$ Miskawaih, Tahdhibu L-Akhlaq. p. 424-431
${ }^{202}$ Miskawaih, Tahdhibu L-Akhlaq. p. 432-435 
bahwa ia memiliki sifat halu'an Allah kemudian memberikan beberapa nasehat agar manusia tidak terjerumus kedalam sifat tersebut:

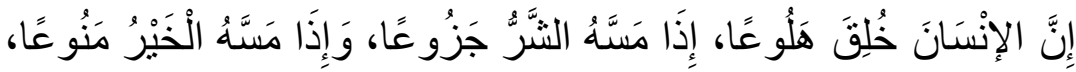

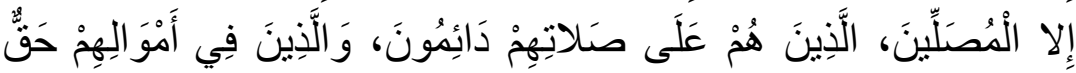

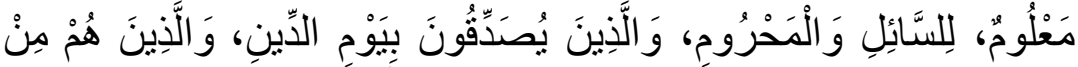

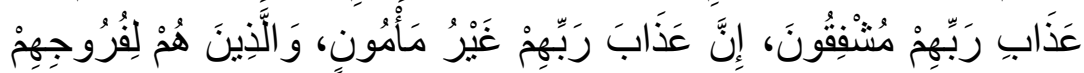

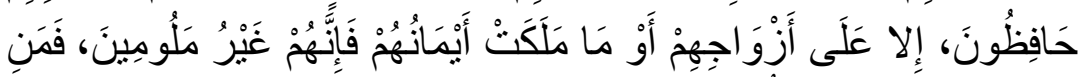

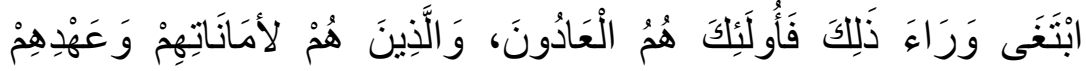

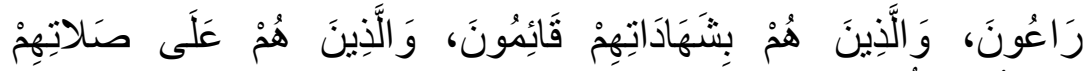

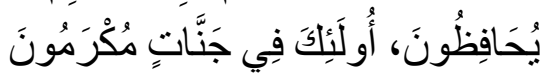

Sesungguhnya manusia diciptakan bersifat halu'an. (halu'an adalah) Apabila ia ditimpa kesusahan ia berkeluh kesah, dan apabila ia mendapat kebaikan ia amat kikir, kecuali orang-orang yang mengerjakan shalat, yang mereka itu tetap mengerjakan shalatnya. Dan orang-orang yang dalam hartanya tersedia bagian tertentu, bagi orang (miskin) yang meminta dan orang yang tidak mempunyai apa-apa (yang tidak mau meminta). Dan orang-orang yang mempercayai hari pembalasan. Dan orang-orang yang takut terhadap azab Tuhannya, karena Sesungguhnya azab Tuhan mereka tidak dapat orang merasa aman. Dan orang-orang yang memelihara kemaluannya, kecuali terhadap isteri-isteri mereka atau budak-budak yang mereka miliki, maka sesungguhnya mereka dalam hal ini tiada tercela. Barangsiapa mencari yang di balik itu, Maka mereka Itulah orang-orang yang melampaui batas. Dan orang-orang yang memelihara amanat-amanat dan janjinya. Dan orang-orang yang memberikan kesaksiannya dengan benar. Dan orang-orang yang memelihara shalatnya. Mereka itu (kekal) di syurga lagi dimuliakan. (Al-Ma'arij: 19-35)

Penjelasan dalam Al-Qur'an ini menunjukkan bahwa seorang muslim yang beraqidah dengan benar, ia beriman kepada Allah dan hari akhir, menjalankan shari'ah dengan seutuhnya, serta akhlaq yang 
baik tercermin dalam perilakunya. Orang yang demikian tidak akan pernah dirundung duka akibat kehilangan, maupun bersifat tamak terhadap dunia yang ia miliki. Karena ia tahu bahwa dunia ini hanyalah sementara, tempat diujinya manusia (دار البلاء) untuk menentukan posisinya di tempat penentuan (دار القرار) apakah ia bahagia (سعيد) ataukah menderita (شقي).

$$
\text { و الله أعلم بالصو اب }
$$




\section{DAFTAR PUSTAKA}

Al-Qur'an Al-Karim

Bible

'Ashur, Sa'ad 'Abdullah, Mawqifu L-Firaq Al-Islamiyyah Min Af'ali l-'Ibad, 2nd edn (Majallah Al-Jaami'ah Al-Islamiyyah, 2001)

'Imarah, Muhammad, Al-Mu'tazilah Wa Mushkilatu l-Hurriyyah Al-Insaniyyah, 2nd edn (Kairo: Daaru s-Syuruq, 1988)

Abdu r-Rahman Hasan Habankah Al-Maydani, Al-Akhlaq Al-Islamiyyah Wa Ususuha, 5th edn (Damaskus: Daaru I-Qalam, 1999)

Acikgenc, Alparslan, Islamic Science: Towards A Definition, 1st edn (Kuala Lumpur: ISTAC, 1996)

Ad-Dabsy, Muhammad, At-Taqwa Fi I-Qur'ani I-Karim; Dirasah Fi Tafsir Al-Maudu'i, 1st edn (Kairo: Daaru I-Muhaddithin, 2008)

- - , Barakat Wa Anwaru L-Qur'an, 1st edn, 2016

Al-'Adhim, Sa'id Abdu, Mafatihu L-Fahmi Wa t-Tadabburi I-Qur'an Wa Tahqiqu n-Najah Fii I-Hayah (Iskandariyyah: Daaru I-Iman, 2005)

- - , Manhaju S-Syaikhu I-Islam Ibnu Taymiyyah As-Salafi Wa Da'watuhu Al-Islahi (Iskandariyyah: Daaru I-Iman)

Al-'Asqalani, Ahmad bin 'Ali bin Hajar, Fathu L-Bari Sharhu Sahih Al-Bukhari, ed. by Muhammad Fu'ad Abdul Baqi, Muhibbu d-Din Al-Khatib, and Abdu I-Azizi bin Abdullah bin Baz (Beirut: Daaru I-Ma'arif)

Al-'Imrani, Yahya bin Abi I-Khayr, Al-Intishar Fi Raddi 'ala I-Qadariyyah Wa I-Mu'tazilah Al-Ashrar (Madinah: Daaru Adwa'u s-Salaf)

Al-Ahmadi, 'Abdu I-Ilah bin Sulayman bin Salim, Al-Masa'il Wa r-Rasa'il Al-Marwiyyah Min Al-Imam Ahmad Bin Hanbal Fi l-'Aqidah, 1st edn (Riyad: Daar Tayyibah, 1991)

Al-Ash'ari, Abu Hasan, Al-Ibanah 'an Ushuli d-Diyanah, 5th edn (Madinah: Al-Mamlakah Al-Su'udiyyah Al-'Arabiyyah)

- - , Al-Luma' Fi Raddi 'Ala Ahli z-Zayghi Wa l-Bida', ed. by Hamudah Gharabah (Mesir: Maktabah Mishr, Shirkah Sahimah Misriyyah, 1955)

Al-Ashbani, Abu Na'im, Ma'rifatu s-Shahabah, ed. by 'Adil bin Yusuf Al-'Azazi (Riyad: Daaru I-Watan lii n-Nashr) 
Al-Ashqari, Umar Sulaiman, Al-'Aqidah 'Ala Dau'i I-Kitab Wa Sunnah, 12th edn (Jordan: Al-Nafaes, 1999)

---, At-Taqwa; Ta'rifuha Wa Fadluha Wa Mahdhuratuha Wa Qishashu Min Ahwaliha, 1st edn (Omman: Daaru n-Nafa'is, 2012)

Al-Attas, Syed Muhammad Naquib, Islam and Secularism, 2nd edn (Kuala Lumpur: ISTAC, 1993)

-- , Prolegomena to The Metaphysic of Islam: An Exposition of The Fundamental Elements of The Worldview of Islam, 1st edn (Kuala Lumpur: ISTAC, 1995)

Al-Badawi, Abdu r-Rahman, Madhahibu L-Islamiyyin (Beirut: Daaru I-'Ulum li I-Maliyyin, 1997)

Al-Bayhaqi, Abu Bakar Ahmad bin Al-Husain, Al-Jami' Li s-Shu'abi I-Iman, ed. by Abdu I-Ali Abdul I-Hamid Hamid, 1st edn (Riyad: Maktabah Al-Rushd, 2003)

Al-Bukhari, Muhammad bin Ismail Abu Abdullah, Al-Jaami' Al-Sahiih Al-Mukhtashar Min Umuuri Rasuulillahi SWT Wa Sunanihi Wa Ayyaamihi, Sahih I-Bukhari, ed. by محمد زهير بن ناصر الناصر and Muhammad Zuhayr bin Naashir Al-Naashir, 1st edn (Damaskus: Daaru t-Tauqi n-Najaah, 2001)

Al-Farabi, Abu Nashr, Araa'u Ahli I-Madinah Al-Fadilah Wa Madhadatuha, ed. by Ali bu Mulham, 1st edn (Beirut: Daar wa Maktabah Al-Hilal, 1995)

- - , Kitabu S-Siyasah Al-Madinah, ed. by Ali bu Mulham (Beirut: Daar wa Maktabah Al-Hilal)

Al-Faruqi, Ismail Raji, Islamization of Knowledge: General Principles and Work Plan, 3rd edn (Virgiana: IIIT, 1997)

Al-Fuyumi, Muhammad Ibrahim, Syaikh Ahlu S-Sunnah Wa I-Jama'ah Al-Imam Abu I-Hasan Al-Ash'ari; Fahs Naqdy Li 'Ilmi I-Kalam Al-Islamy, ed. by 2003, 1st edn (Kairo: Daaru I-Fikri Al-'Araby, 2003)

Al-Ghazali, Abu Hamid Muhammad bin Muhammad, Ihya' Ulumuddin, 1st edn (Beirut: Daar Ibnu Hazm, 2005)

Al-Hanbali, Al-Qadi Abu Ya'la Muhammad Husain Al-Farra', Kitabu T-Tawakkal, ed. by Yusuf binn 'Ali At-Tarif, 1st edn (Riyad: Daaru 
I-Mayman, 2014)

Al-Jaza'iri, Abu Bakar, 'Aqidatu I-Mu'Min (Kairo: Daaru I-Aqidah, 2004)

Al-Jurjani, Ali Bin Muhammad, Al-Ta'rifat, 1st edn (Beirut: Maktabah Lubnan, 1985)

Al-Juwayni, Imam Al-Haramain, Kitabu L-Irshad Ila Qawati'i I-Adillah Fii Ushuli I-I'tiqad, ed. by Muhammad Yusuf Musa and Ali Abdu I-Mun'im Abdul-Hamid (Mesir: Matba'ah Al-Sa'adah, 1950)

Al-Katsir, 'Imad al-Din Abi al-Fida' 'Isma'il Ibn, Tafsir Al-Quran Al-'Adzim, 1st edn (Kairo: Al-Faruq al-Hadits, 2000)

Al-Khallali, Abu Bakar Ahmad bin Muhammad bin Harun, Al-Hathu 'ala t-Tijarah Wa s-Shina'ah Wa l-'Aamal Wa I-Inkar 'Ala Man Yadda'i At-Tawakkal Fii Tarki l-'Amal Wa l-Hujjah 'Alayhim Fii Dhalika, 1st edn (Riyad: Daaru l-'Ashimah)

Al-Kharraz, Khalid bin Jum'ah bin Uthman, Mausu'atu I-Akhlaq, 1st edn (Kuwait: Maktabah Ahli I-Athar, 2009)

Al-Mahdili, Muhammad 'Aqil Bin 'Ali, Dirasatun Fi L-Sam'iyyat, 1st edn (Kairo: Dar I-Hadits, 1996)

Al-Maqrizi, Taqiyuddin Ahmad bin Ali, Tajridu T-Tauhid Al-Mufid (Kairo: Markaz I-Kitab li n-Nashr)

Al-Maturidi, Abu Manshur Muhammad bin Muhammad, Kitab At-Tauhid (Beirut: Daar Shadir, 2001)

-- -, Tafsir Al-Maturidi; Ta'wilat Ahli s-Sunnah, ed. by Majdi Baslum, 1st edn (Beirut: Daaru I-Kutub al-IImiyyah, 2005)

Al-Maududi, Abu I-A'laa, Al-Hijab, 2nd edn (Damaskus: Daaru I-Fikri, 1964)

Al-Mawardi, Abu Hasan Ali bin Muhammad, A'laamu n-Nubuwwah, 1st edn (Beirut: Daaru I-Kutub al-Ilmiyyah, 1986)

Al-Mu'tazili, Abdu I-Qadi Abdu I-Jabbar Al-Asadi Al-Aabaadi Al-Hamdani, Al-Mughni Fi Abwabi t-Tauhid Wa l-'Adl (Mesir: Wizarah Al-Thaqafah Al-Mishriyyah)

- - , Sharh Ushuli L-Khamsah, 3rd edn (Mesir: Maktabah Wahbah, 1996)

Al-Muhsin, 'Abdu Al-Razzaq bin Abdu, No Title, Al-Qaul Al-Sadid Fi Ar-Raddi 'Ala Man Ankara Taqsima t-Tauhid, Cet: 1 (Riyad: Dar Ibnu I-Qayyim, 
2003)

Al-Munjid, Muhammad Shalih, A'malu I-Qulub; At-Taqwa, 1st edn (Jeddah: Zad Group, 2009)

Al-Qadi, Yasir, Maqalat Al-Jahm Bin Shafwan Wa Atharuha Fi I-Firaq Al-Islami, 1st edn (Riyad: Daaru Adwa'u s-Salaf, 2005)

Al-Qahtani, Sa'id bin 'Ali bin Wahf, Nur T-Tauhid Wa Dhulmatu s-Shirk Fi Dau'i I-Kitab Wa s-Sunnah, 3rd edn (Riyad: Maktabah Malik Fahd, 2000)

Al-Qushairi, Abu I-Qasim, Al-Risalah Al-Qushairiyyah, ed. by Abdu I-Halim Mahmud (Kairo: Daaru s-Sha'b, 1989)

Al-Razi, Fakhr al-Din, Tafsir Al-Fakhr Al-Razi Al-Mushtahir Bi-Tafsir Al-Kabir Mafatih Al-Ghaib, 1st edn (Beirut: Dar al-Fikr, 1981)

Al-Razi, Fakhru d-Din Muhammad bin Umar, Kitabu N-Nafsi Wa r-Ruhi Wa Sharhu Quwaha, ed. by Muhammad Shagir Al-Ma'shumi (Islamabad-Pakistan: Ma'had Al-Abhath Al-Islamiyyah)

Al-Sanusi, Abu Abdullah Muhammad Bin Yusuf, Sharhu L-Muqaddimat, ed. by Nazar Hamadi, 1st edn (Riyad: Maktabah I-Ma'arif, 2009)

Al-Subhani, Syeikh Ja'far, Ar-Risalah Fii t-Tahsin Wa t-Taqbih, 1st edn (Qom: Mu'assasah Al-Imam As-Shadiq, 1999)

Al-Syahrani, Ayid bin Abdullah bin Abdu I-'Aziz, At-Tahsin Wa At-Taqbih Aqliyani Wa Atharuhuma Fii Masaa'ili Ushuli I-Figh Ma'a Munaqashah Al-'Ilmiyyah Li Ushuli I-Madrasah Al-'Aqliyyah Al-Hadithah, 1st edn (Riyad: Daaru I-Kunuz Ishbelia, 2008)

Al-Tarifi, Abdu I-Aziz Marzuq, Al-Hijab Fi I-Shar' Wa l-Fitrah, 1st edn (Riyad: Maktabah Darul Manhaj)

Al-Thabari, Abi Ja'far Muhammad Ibn Jarir, Tafsir Al-Thabari Jami' Al-Bayan 'an Ta'wil Ay Al-Quran, 1st edn (Kairo: Dar al-Hijr, 2001)

Al-Tirmidzi, Abu Isa, Sunan Al-Tirmidzi, ed. by Ahmad Muhammad Syakir Muhammad Fuad Abdul Baqi (Mesir: Shirkah Maktabah wa Matba'ah Al-Babi Al-Halbi, 1985)

Al-Tusi, Abu Nasr Sarraj, Al-Luma' (Mesir: Daaru I-Kutub al-Hadithah, 1960)

Al-Wali, Husain, Kitab Kalimatu T-Tauhid, 1st edn (Mesir: Maktabah Al-Wa'idz, 1908) 
Al-Zabidi, Muhammad Murtadha Al-Husaini, Taaju L-'Aruus Min Jawahiri I-Qamus, ed. by Musthafa Hijazi, 2nd edn (Kuwait: Matba'ah Hukumah Kuwait, 1987)

Al-Zamakhsyari, Abu Qasim Mahmud bin Umar, Al-Kasyaf Fi Haqaiqi Ghawamidi t-Tanzil, Wa 'Uyuni l-Aqawil Fii Wujuhi t-Ta'wil, 1st edn (Riyad: Maktabah Al-Abykan, 1998)

An-Nawawi, Abu Zakariyya Yahya bin Sharifu d-Din As-Syafi'i, At-Tibyan Fii Adab Hamlati I-Qur'an, ed. by Bashir Muhammad 'Uyun, 1st edn (Beirut: Maktabah Al-Mu'ayyad, 1991)

Aristotle, Aristotle's Metaphysics, ed. by W. D. Ross (Oxford: Clarendon Press, 1924)

- - , The Nicomachean Ethics, ed. by F.H. Peters, 4th edn (London: Kegan Paul, Trench, Trubner \& co., Itd., 1891)

Armstrong, Karen, A History of God: The 4,000-Year Quest of Judaism, Christianity and Islam, 1st edn (New York: Ballantine Books, 1994)

As-Syaukani, Muhammad Bin Ali, Irshadu L-Tsiqah Ila Ittifaqi s-Shara'i' 'Ala I-Tawhid Wa I-Ma'Ad Wa I- Nubuwat, 1st edn (Beirut: Daaru I-Kutub al-Ilmiyyah, 1984)

At-Tamimi, Muhammad Khalifah Bin Ali, Huququ N-Nabiy 'ala Ummatihi Fii Dau'i I-Kitab Wa s-Sunnah, 1st edn (Riyad: Adwa'u s-Salaf, 1997)

At-Thabari, Abu Ja'far bin Jarir, Sahih Tarikhu T-Thabari, 1st edn (Beirut: Dar Ibnu Kathir, 2007)

-- , Tafsir At-Thabari, Jami'u I-Bayan 'an Ta'Wil Ay I-Qur'an, 1st edn (Kairo: Dar Hijr, 2001)

Avicenna, Ibnu Sina, 'Uyunu l-Hikmah, ed. by Abdu r-Rahman Al-Badawi, 2nd edn (Beirut: Daaru I-Qalam, 1980)

Avicenna, Ibnu Sina, and Abu Nasr At-Tusi, Al-Isharat Wa At-Tanbihat Vol IV, Fi t-Tasawuf, ed. by Sulayman Dunya, 2nd edn (Mesir: Daaru I-Ma'arif, 1968)

Avicenna, Ibnu Sina, and Fadlur Rahman, Avicenna's De Anima (Arabic Text) Being The Psychological Part of Kitab Al-Shifa', ed. by Fadlur Rahman (London: Oxford University Press, 1959)

Ayub, Hasan, Tabsit L-Aqa'id I-Islamiyyah, 5th edn (Beirut: Daaru n-Nadwah 
al-Jadidah, 1983)

Bajah, Abu Bakar Muhammmad Bin, Kitab An-Nafs, ed. by Muhammad Shaghir Hasan Al-Ma'shumi, 2nd edn (Beirut: Daar Shadir, 1992)

Bucaille, Maurice, The Bible, The Qur'an and Science, ed. by Alastair D. Pannel and Maurice Bucaille (Lahore: Kazi Publications)

Cécile Laborde, Critical Republicanism: The Hijab Controversy and Political Philosophy, 1st edn (New York: Oxford University Press, 2008)

Darwish, Nonie, Cruel and Usual Punishment (Nashville: Thomas Nelson.Inc, 2008)

Descartes, René, Meditation on First Philosophy With Selections from the Objections and Replies, ed. by Michael Moriarty, 1st edn (New York: Oxford University Press, 2008)

Dunya, Abu, At-Tawakkal 'ala Allah, 1st edn (Beirut: Daaru I-Basha'ir Al-Islamiyyah, 1987)

-- , Makarimu L-Akhlaq (Bulaq: Maktabah Al-Qur'an, 1990)

Fowlers, H.W., Oxford Fowler's Modern English Usage, ed. by Sir Ernest Gower, 2nd edn (Oxford: Oxford University Press, 1985)

Gharabah, Mahmud, Abu L-Hasan Al-Ash'ari (Kairo: Al-Matabi' Al-Amiriyyah, 1983)

Grace, Daphne, The Woman in the Muslim Mask, 1st edn (London: Pluto Press, 2004) <http://www.jstor.org/stable/j.ctt183q4r8>

Hamka, Dari Perbendaharaan Lama, 2nd edn (Jakarta: Pustaka Panjimas, 1982)

Hawa, Sa'id, Al-Asas Fi s-Sunnah Wa Fiqhuha, 2nd edn (Kairo: Daaru s-Salam, 1992)

Herdt, Gilbert, Moral Panics, Sex Panics: Fear and Fight over Sexual Rights, ed. by Gilbert Herdt (New York: New York University Press, 2009)

Honderich, Ted, The Oxford Companion to Philosophy, 2nd edn (Oxford: Oxford University Press, 2005)

Ibn 'Athiyah, Abu Muhammad 'Abdu al-Haq Ibn al-Ghalib, Al-Muharrar Al-Wajiz Fi Tafsir Al-Kitab Al-'Aziz, 1st edn (Beirut: Daaru I-Kutub al-Ilmiyyah, 2001) 
Ibn Juziyi, al-Qasim Muhammad Ibn, Al-Tashil Li-'Ulum Al-Tanzil, 1st edn (Beirut: Daaru I-Kutub al-Ilmiyyah, 1998)

Ibnu I-Qayyim Al-Jawziyyah, Abu Abdillah Muhammad bin Abi Bakr Bin Ayyub, Madariju S-Salikin Bayna Manazili lyyaka Na'budu Wa lyyaka Nasta'in, ed. by Muhammad Hamid Al-Fiqi (Beirut: Daaru I-Kutub al-'Arabi)

---, Miftahu D-Daru s-Sa'adah Wa Manshur Wilayatu I-'Ilmi Wa I-Iradah (Beirut: Daaru I-Kutub al-Ilmiyyah, 1998)

-- , Shifa'u I-'Alil Fi Masa'ili I-Qada' Wa I-Qadar Wa I-Hikmah Wa t-Ta'lil (Kairo: Maktabah Daaru t-Turath)

Ibnu Taimiyyah, Taqiyuddin Ahmad, Al-Fatawa Al-Humiyyah Al-Kubra, ed. by Hamad bin Abdu I-Muhsin At-Taujiri, 2nd edn (Riyad: Daaru s-Shami'i, 2004)

-- -, Al-Mustadrak 'ala Majmu'i I-Fatawa: Al-Mujallad Al-Awwal Mina I-'Aqa'id Ila t-Tafsir (Saudi)

- - , Kitab Al-Raddu 'Ala I-Mantiqiyyin, ed. by Sayyid Sulayman Al-Nadawi, Abdu s-Samad Sharafu d-Din Al-Katibi, and Muhammad Talhah Bilal Minar, 1st edn (Beirut: Mu'assasah Al-Rayyan, 2005)

---, Majmu' Fatawa (Kairo: Daru I-Wafa', 2005)

Isma'il Bin Hammad Al-Jawhari, Al-Sihhah, Taaj Ul-Lughah Wa Sihhahu I-Arabiyyah, ed. by Ahmad Abdul Ghafur Al-Attar, 4th edn (Beirut: Daaru I-Alam li I-Malayiin, 1990)

James W. Sire, The Universe Next Door: A Basic Worldview Catalog, 5th edn (Illionis: InterVarsity Press, 2009)

James, William, The Varieties of Religious Experience a Study in Human Nature (New York: The Modern Library, 1902)

Kathir, Isma'il bin, Al-Bidaayah Wa n-Nihaayah, 1st edn (Giza: Daaru I-Hijr, 1997)

Khan, Wahidu d-Din, Al-Islam Yatahadda, ed. by Zafarul Islam Khan, 4th edn (New Delhi: Goodword Books, 2005)

L-Wahhab, Ya'qub bin Abdu, Qo'idah 'Al-'Adah Muhakkamah': Dirasah Ta'siliyyah, Tatbiqiyyah, 2nd edn (Riyad: Maktabah Rusyd, 2012) 
Law, Stephen, Philosophy: History, Ideas, Theories, Who's Who, How to Think, 1st edn (London: Dorling Kindersley, 2007)

Majah, Ibnu, Sunan Ibnu Majah, 1st edn (Riyad: Maktabah I-Ma'arif)

Mandzur, Ibnu, Lisaanu L-'Arab (Kairo: Daaru I-Ma'arif)

Marnia Lazerg, Questioning the Veil: Open Letters to Muslim Women (Princenton: Princenton University Press, 2019) <https://doi.org/10.1145/3132847.3132886>

Miskawaih, Ibnu, Tahdhibu L-Akhlaq, ed. by Imad Al-Hilali (Beirut: Manshurat Jamal, 2011)

-- , Tahdzibu L-Akhlaq Wa Tathiru I-A'raq, 1st edn (Beirut: Daaru I-Kutub, 1985)

Muhammadiyah, PP, Himpunan Putusan Tarjih Muhammadiyah (HPT) (Yogyakarta: Suara Muhammadiyah, 2011)

Muslim, Al-Musnad Al-Sahih Al-Mukhtasar Bi Naqli I-Adli Mina I-Adli Ila Rasulillahi, ed. by Muhammad Fu'ad Abdu L-Baqi (Bairut: Daaru I-Ihya'u t-Turath Al-Arabi)

Naugle, David Keith, 'The History and Theory of the Concept Weltanschauung' (The University of Texas, 1998)

Nietzsche, Friedrich W., Thus Spake Zarathustra, ed. by Thomas Common (USA: The Modern Libarary)

Panichas, Lori Gruen and George E., Sex, Morality and The Law (New York: Routledge, 1997)

Perry, Michael J., Morality, Politics, and Law, 1st edn (New York: Oxford University Press, 1998)

Plotinus, Enneads, ed. by A.H. Armstrong (London: Harvard University Press, 1988)

Qardawi, Yusuf, Al-Halal-Wa I-Haram Fi I-Islam, 22nd edn (Kairo: Maktabah Wahbah, 1997)

Qutb, Sayyid, Khasais At-Tasawwur Al-Islami Wa Maqumatuhu, 5th edn (Beirut: Daaru s-Syuruq, 1997)

Russel, Bertrand, History of Western Philosophy and Its Connection With Political and Social Circumstances From the Earliest Times to The 
Present Days, 2nd edn (New York: George Allen and Unwin LTD, 1949)

Rusyd, Ibnu, Al-Kasyf Fi Manahiji I-Adillah Fi Aqa'idi I-Millah, ed. by Muhammad Abid Al-Jabiri, 1st edn (Beirut: Markaz Daru I-Wihdah Al-Arabiyyah, 1998)

Sims, Martha C., Living Folklore: An Introduction to the Study of People and Their Traditions (Logan, Utah: Utah State University Press, 2005)

Sire, James W., Naming the Elephant: Worldview as a Concept (Illionis: Intervarsity Press, 2010) <https://doi.org/10.1163/157338308X365567>

Smart, Ninian, Worldviews Cultural Exploraties of Human Biliefs, 2nd edn (New York: Charles Scribner's Sons)

Spielvogel, Jackson J., Western Civilization, 7th edn (Canada: Thomson Wadsworth)

Steinhart, Eric, On Nietzsche (USA: Wadsworth, 2000)

Tufail, Ibnu, 'Hayy Bin Yaqdzan', in Hayy Bin Yaqdzan Li Ibni Sina Wa Ibni Tufail Wa Al-Suhrawardi, ed. by Ahmad Amin, Muhammad Azb, and Sulayman Al-Attar, 4th edn (Beirut: Daaru I-Ma'arif, 2007)

Yasri, Muhammad, 'Ilmu t-Tauhid 'Inda Ahl s-Sunnah Wa l-Jama'Ah, 1st edn >slamkotob.com> (سلسلة المدخل الدفيد إلى علم التوحيد 1, 2004)

Yusuf, Hanim Ibrahim, Ashlu L-'Adl 'inda I-Mu'tazilah, 1st edn (Nasr: Daaru I-fikri Al-'Araby, 1993)

Zakariya, Abu Bakar Muhammad, As-Shirk Fi I-Qadim Wa I-Hadith Juz : 1, 1st edn ((Riyadh: Maktabatu r-Rushdi, 2000)

Zarkasyi, Amal Fathullah, IImu L-Kalam; Tarikhu I-Madhahib Al-Islamiyyah Wa Qadayaha Al-Kalamiyyah (Ponorogo: Jaami'atu d-Daaru s-Salaam, 2006) 